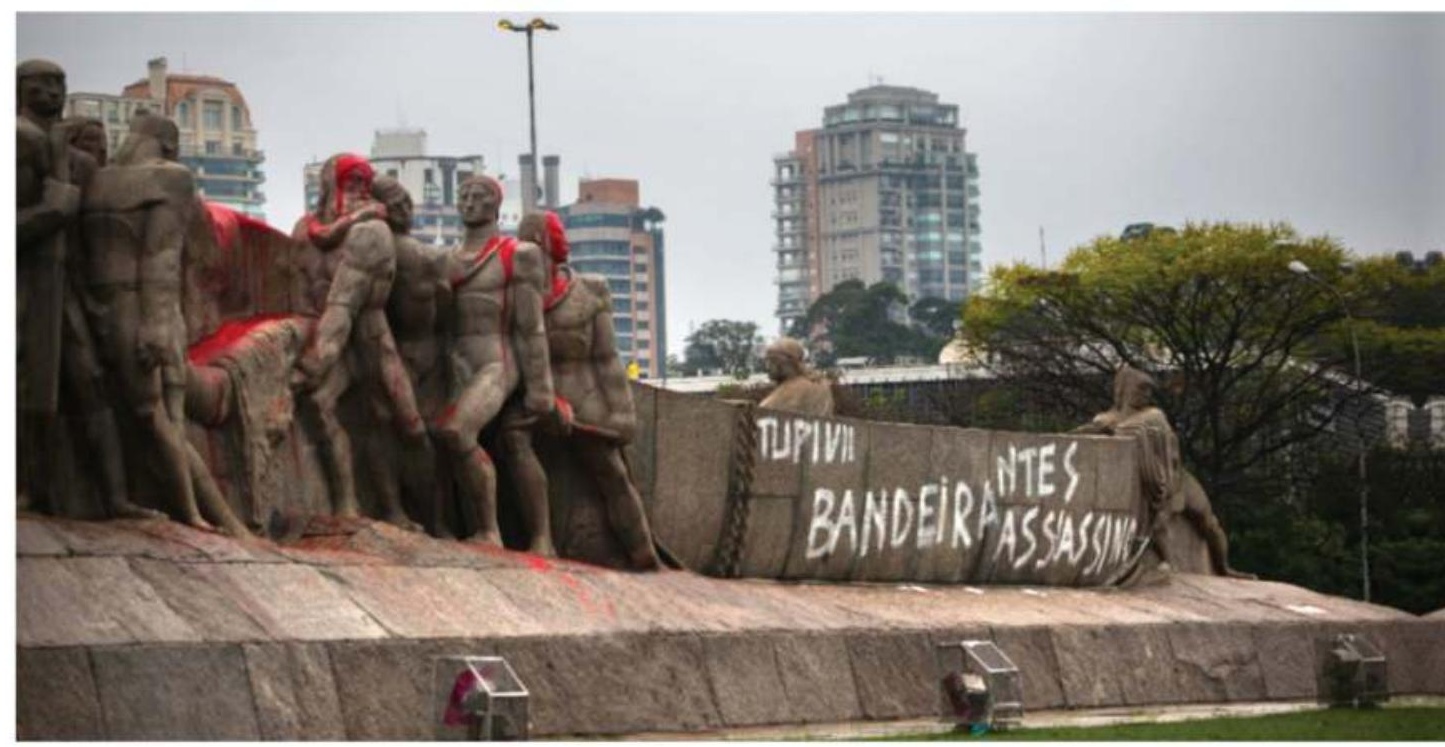

cantemparary fispanic and lusaphane cultures

\title{
anti-empire
}

decolonial interventions in lusophone literatures

daniel f. silva 


\title{
Contemporary Hispanic and Lusophone Cultures
}

\author{
Series Editors \\ L. Elena Delgado, University of Illinois at Urbana-Champaign \\ Niamh Thornton, University of Liverpool \\ Series Editorial Board \\ Jo Labanyi, New York University \\ Chris Perriam, University of Manchester \\ Paul Julian Smith, CUNY Graduate Center
}

This series aims to provide a forum for new research on modern and contemporary hispanic and lusophone cultures and writing. The volumes published in Contemporary Hispanic and Lusophone Cultures reflect a wide variety of critical practices and theoretical approaches, in harmony with the intellectual, cultural and social developments that have taken place over the past few decades. All manifestations of contemporary hispanic and lusophone culture and expression are considered, including literature, cinema, popular culture, theory. The volumes in the series will participate in the wider debate on key aspects of contemporary culture.

5 Kirsty Hooper, Writing Galicia into the World: New Cartographies, New Poetics

6 Ann Davies, Spanish Spaces: Landscape, Space and Place in Contemporary Spanish Culture

7 Edgar Illas, Thinking Barcelona: Ideologies of a Global City

8 Joan Ramon Resina, Iberian Modalities: A Relational Approach to the Study of Culture in the Iberian Peninsula

9 Bruno Carvalho, Porous City: A Cultural History of Rio de Janeiro (from the 1810s Onward)

10 Javier Krauel, Imperial Emotions: Cultural Responses to Myths of Empire in Fin-de-Siècle Spain

11 Luis Moreno-Caballud, translated by Linda Grabner, Cultures of Anyone: Studies on Cultural Democratization in the Spanish Neoliberal Crisis

12 H. Rosi Song, Lost in Transition: Constructing Memory in Contemporary Spain

13 Andrés Zamora, Featuring Post-National Spain: Film Essays

14 Paul Julian Smith, Dramatized Societies: Quality Television in Spain and Mexico

15 Joan Ramon Resina, The Ghost in the Constitution: Historical Memory and Denial in Spanish Society

16 José Colmeiro, Peripheral Visions/Global Sounds: From Galicia to the World

17 Regina Galasso, Translating New York: The City's Languages in Iberian Literatures 


\title{
Anti-Empire
}

\section{Decolonial Interventions in Lusophone Literatures}

\author{
DANIEL F. SILVA
}


First published 2018 by Liverpool University Press

4 Cambridge Street

Liverpool

L69 7ZU

Copyright (C) 2018 Daniel F. Silva

The right of Daniel F. Silva to be identified as the author of this book has been asserted by him in accordance with the Copyright, Designs and Patents Act 1988.

All rights reserved. No part of this book may be reproduced, stored in a retrieval system, or transmitted, in any form or by any means, electronic, mechanical, photocopying, recording, or otherwise, without the prior written permission of the publisher.

British Library Cataloguing-in-Publication data

A British Library CIP record is available

print ISBN 978-1-78694-100-8 cased epdf ISBN 978-1-78694-937-0

Typeset in Borges by

Carnegie Book Production, Lancaster 
To

Juana Gamero de Coca

in memoriam 



\section{Contents}

Acknowledgments $\quad$ ix

Introduction 1

1 Decolonizing Consumption and Postcoloniality: A Theory of Allegory in Oswald de Andrade's Antropofagia 33

2 Mário de Andrade's Antropofagia and Macunaíma as Anti-Imperial Scene of Writing 69

3 Toward a Multicultural Ethics and Decolonial Meta-Identity in the Work of Fernando Sylvan 106

4 Untranslatable Subalternity and Historicizing Empire's Enjoyment in Luís Cardoso's Requiem para o Navegador Solitário

5 Imperial Cryptonomy: Colonial Specters and Portuguese Exceptionalism in Isabela Figueiredo's Caderno de Memórias Coloniais

6 Spectrality as Decolonial Narrative Device for Colonial Experience in António Lobo Antunes's O Esplendor de Portugal

7 Decolonizing Hybridity through Intersectionality and Diaspora in the Poetry of Olinda Beja

8 Transgendering Jesus: Mário Lúcio’s O Novíssimo Testamento and the Dismantling of Imperial Categories 
viii Anti-Empire: Decolonial Interventions in Lusophone Literatures Conclusion 287

Bibliography 290

Index 


\section{Acknowledgments}

Wish to begin by thanking the numerous individuals who have helped 1 immensely in the publishing process, beginning with the editors of the Contemporary Hispanic and Lusophone Cultures series, L. Elena Delgado and Niamh Thornton, for believing in my project at the earliest stages and providing me with the opportunity to contribute to such an established series. My gratitude must also go to Anthony Cond and Chloe Johnson, my editors at Liverpool University Press, for their constant support and help. Sincere thanks also go to the anonymous reviewers for seeing value in my work and for offering precious feedback and commentary that has vastly improved this project. I must also thank the copy editors and typesetters for their dedicated combing through of my manuscript. I am very gracious, additionally, to every member of the Liverpool University Press team who has in some way worked on my manuscript in the publication process. I thank you for making this book possible.

Very heartfelt thanks must also go to my friends and colleagues at Middlebury College who have both embraced my work and contributed to the ideas contained therein. In addition to the Department of Spanish and Portuguese, I must especially thank Marcos Rohena-Madrazo, Yumna Siddiqi, Nikolina Dobreva, Sujata Moorti, Laurie Essig, and Tamar Mayer. I am also indebted to the amazing students I have had the privilege of teaching at Middlebury. Their sublime engagement with the topics covered in this book has profoundly shaped its premises and has propelled it forward. The Center for the Comparative Study of Race and Ethnicity and the Anderson Freeman Center have become my intellectual and affective home at Middlebury College.

A most sincere thank you must also go to Lamonte Aidoo for being a true friend, a constant source of encouragement, and a brilliant interlocutor since our days in graduate school. A lot of the ideas and readings proposed here began to take shape during my time as a Ph.D. student at Brown University. I am, therefore, profoundly indebted to numerous professors from whom I had 
the privilege of learning and that deeply impacted the development of this book. These include, but are not limited to, Leonor Simas-Almeida, Nelson H. Vieira, Anani Dzidzienyo, Luiz F. Valente, Olakunle George, Cristiana Bastos, and Miguel Jerónimo Bandeira.

A word of thanks must also go to my entire family for always being supportive and understanding of my work schedule (or lack thereof). Finally, my most profound and infinite thanks to my partner in everything, Jennifer, for her love, support, strength, laughter, brilliance, and for paving smooth roads on life's arduous journeys. 


\section{Introduction}

Tind myself with the anxiety-inducing task of opening this book with 1 a conundrum due largely, but not exclusively, to the title I have settled on. The literary objects of study within this book certainly led me to it, but defining the terms contained in the title without the crutch of these texts poses significant challenges. Firstly, any attempt to cognitively pin down the contours of imperialism is painstakingly like trying to grasp an oily yet viscous liquid. Although I will endeavor to do so here in the introduction, the totality of this project will hopefully provide a more complete answer. Nonetheless, and perhaps as a disclaimer, discussing imperial power often leads to the fallacy of designating its limits. Western imperialism, as I shall consider, has very much constructed its own world, in the Heideggerian sense, and therefore, establishing its limits - where or when it exists - is an exercise in futility. If I can think of a phrase that unites the texts I will explore in relation to imperial power it would be something to the effect of: 'Empire is here and now, let's tackle it.' The texts, though, do in fact offer nuanced insights into how imperial power has arrived at its present moment, all the while imagining ways out of it. The broadly encompassing nature of imperial power, however, renders any study of it incomplete.

For the sake of semantic and conceptual clarity, it is important to distinguish the existence of western imperial power from European national imperial projects. As I shall discuss, imperial power resides in and reproduces a particular field of meaning to which national imperial projects have contributed. The literary texts to be studied here share both experiences of imperial power and of a particular national imperial endeavor - Portuguese colonialism. Like other national empires, Portuguese expansion brought with it its own textual fabric, overlapping with and contributing to broader imperial power and the construction of the West. To be clear about a contentious topic to be discussed further on in this introduction, no specificity or particularity concerning Portuguese expansion and Portugal's 
more than 500-year imperial story disrupts imperial power, but rather reproduces it.

One of the first European nations to take to the sea, Portugal's expansion began with the conquest of Ceuta in 1415. What notably accompanied Portuguese overseas conquests was an adjacent historicizing project embodied by the kingdom's appointment of chroniclers, beginning with Fernão Lopes. Chroniclers like Lopes provided a politically driven historiography to the nation and nascent empire, one which would legitimate and normalize the power of the kingdom over its subjects at home and abroad. The work of such chroniclers articulated racial, religious, sexual, and economic otherness during both the Iberian Reconquest against Islamic presence and the claiming of markets along the western and eastern coasts of Africa, throughout the Indian Ocean, and as far as Southeast Asia and Japan. Gomes Eanes de Zurara's Chronica do Descobrimento e Conquista da Guiné [Chronicle of the Discovery and Conquest of Guinea], completed in 1453, for instance, offers an early example of the exoticization of African bodies and their placement into European intercontinental narratives under the sign of otherness. The same can be said of South American indigenous bodies in the best-known work of another chronicler, Pero Vaz de Caminha's Carta do Achamento do Brasil ['Letter on the Discovery of Brazil'] of 1500.

As Portugal's expansion across the southern hemisphere progressed, so too did its textual existence and that of the West more broadly, simultaneously subsuming time, space, and bodies into their overlapping fields of meaning. Some examples of these will be discussed in different chapters of Anti-Empire. Throughout the more than five centuries of imperial endeavor, complex discursive maneuvers and phenomena accompanied political, economic, and cultural dominance, even when it was most fleeting.

The current project therefore places Portuguese imperialism within a geopolitically broader understanding of imperial power in order to examine the repercussions of the former for the latter, and vice versa. In this sense, the disciplinary goal here is twofold: exploring what the development of the Portuguese imperial project can teach us about imperial power and meanings while, more importantly, offering a study of Portuguese imperialism - and resistance to it - through a broader framework beyond its own contexts. The literary texts implore us to recognize that Portuguese imperialism cannot be separated from the formation of a matrix of power and concomitant discursive field that has impacted humanity from the early modern period and slave-based capitalism to industrialism and late capitalism. The postcolonial poetics of these works call our attention and critical eye to both Portuguese imperial endeavors and a global order of power (at different historical stages), and to the relationship between the 
two. While the framework of this project is geopolitically broader, going beyond Portuguese imperialism, the conceptualization of Empire through which literary works and history are analyzed here ultimately serves to dig deeper into Portuguese imperial history by pinpointing and examining the inner workings, substrata, and micro levels of power (always intimately bonded to the macro) - namely desire, subjectivation, and different layers of narrativization such as the relationship between dominant historiographies and colonial discourse. ${ }^{1}$ By the same token, the literary interlocutors of this undertaking offer valuable responses, questions, and additions that enrich the study of these topics.

More than writing in a common language and thus being part of Lusofonia, what truly unites these writers and their works is the dialogue on the intricacies behind Portuguese imperial history ensnared in wider imperial Western history and late capitalism in addition to the impulse to move beyond language-centered and imperial-national conceptualizations of political engagement and cultural production. In this regard, the term 'Lusophone literatures' in the title is, more than anything, a placeholder for emergent perceptions and taxonomies of the postcolonial global present in order to understand and grapple with the contemporary formulations of Western imperial power which, more than ever, elude national and linguistic categories. Many of the postcolonial and anti-imperial voices contained in the texts studied here convey their experiences and address imperial power on a global scale rather than one limited to the acts, policies, and discourses of Portuguese imperial presence.

In other words, the effects of Portuguese imperialism were often felt by subaltern identities through more than the purview of Portuguese power and its specific narratives, but rather in its relationship to other imperial powers and the set of meanings, objectives of domination, and modes of violence (physical and epistemic) which they together espoused and carried out. This sort of collaboration is what Laura Doyle calls 'inter-imperiality' (see 'Inter-Imperiality'). The history of East Timor, which both Fernando Sylvan and Luís Cardoso touch upon, offers an important example of this with the intermingling of Portuguese, Dutch, English, Japanese, Australian, and later Indonesian (and by extension US) imperial ambitions. The African slave trade was, moreover, arguably the largest inter-imperial enterprise in terms of humanitarian implications, labor and surplus value, the development of capitalism, the 'coloniality of power' in the Americas (more on this below),

1 Several scholars in the field of Lusophone studies have tackled these machinations of imperial power, notably Luís Madureira, Phillip Rothwell, and Ana Paula Ferreira. 
and the discursive content articulating the discardability and violability of, as well as the need to police, black bodies to this very day. At the heart of this collaboration, one that fomented and cemented the power and economic success of many empires, one can find the Portuguese. ${ }^{2}$

The approach taken to Empire in this project thus considers inter-imperial relations to be more than economic and political, but also as contributing to dominant narratives of time, space, bodies, and objects. Portuguese imperial endeavor contributed in myriad ways, for instance, to the formation of what Dipesh Chakrabarty has termed the 'artifice of history' in which "Europe" remains the theoretical subject of all histories, including the ones we call "Indian," "Chinese," "Kenyan," and so on' (263). Chakrabarty goes on to point out the "peculiar way in which all these other histories tend to become variations on a master narrative that could be called "the history of Europe" (263). The political/military and significational operations of Empire intersect most notably at the silencing of colonized voices (dialectically colonized because silenced, and silenced because colonized) and the production of a dominant historicizing gaze. In this sense, the Portuguese imperial mission, including its role in the slave trade, contributed immensely to this systemic silencing and concomitant formation of Europe's right to signify. The Portuguese imperial agents that emerge in the works studied here exercise power and privilege not only for and within Portuguese imperial objectives, but also for the existence of imperial power more broadly. On a related note, the works examined in chapters 1 and 2 chart the historical development of Brazil as both colony and nation-sign constructed by broader imperial forces including Portuguese colonialism, as well as the post-independence maintenance of slavery, the role of the eugenics movement as an imperial mode of knowledge, and the relationship between industrialism in Brazil and global economic power.

Subaltern experiences of imperial power were seldom limited to the direct effects of one particular imperial project. As a result, imperial power and subalternity cannot be understood or conveyed through the prism of one imperial project alone, in this case, Portuguese imperialism. Similarly, the effects of Portuguese imperialism cannot be fully understood without examining how it interacted with other imperial projects. The social realities and hierarchies constructed through the ideology of Empire made it so that taxonomies of human life translated across imperial/national boundaries.

2 Herbert S. Klein's The Atlantic Slave Trade intricately fleshes out inter-imperial relations that undergirded the slave trade, including the central role played by the Portuguese empire. 
Intersecting imperial notions of race, gender identity, labor, and sexuality enabled bodies and spaces across the colonized world to be understood through similar lenses. These taxonomies became criteria for individual movement, pleasure, and profit on the one hand and, on the other, violence, suffering, displacement, and erasure. The examples of colonial Dili in chapters 3 and 4 illustrate how colonial space, under the political control of one imperial nation (Portugal) is nonetheless open to other privileged identities within Empire while subaltern identities, namely women of color, are objects of the aforementioned pleasure and profit - an example of what Elleke Boehmer considers the 'history of intersecting patriarchies that was part of colonialism' (7). As a result of a broader theoretical framework, we can better pinpoint the intersectional nature of imperial power, privilege and subalternity being formulated through the intermingling of race, gender, sexuality, labor, (dis)ability, age, ethnicity, and location. In this sense, the current study contributes to both decolonial and postcolonial studies a sustained exploration of intersectionality and the intersectionally created subject positions constituting Empire's signifying chain.

The fact that experiences of colonization and Empire are such visceral and recurring themes not only in the texts studied here, but also in many others written in Portuguese, speaks to the impact of imperialism as more than a historical period; as a reality-constituting entity, past and present, formulated by varying forces from imperial networks. The very language chosen by many of these writers - Portuguese (many are natively multilingual) - stands as a reminder of this global reality. The decision to write in Portuguese for postcolonial writers in the Lusophone sphere speaks to disparities in cultural capital and circulation between imperial and non-imperial languages.

In a similar vein, the insights offered by these works written in inter-imperial Lusophone contexts represent important additions to broader approaches to imperialism, decolonial studies, and postcolonial theory. This is not because Lusophone contexts are inherently different, though they imply variations on imperial forms presented by other imperial endeavors. Some of these theoretically helpful variations pertain to grappling with 'post-race' narratives, hybridity, and exceptionalist re-historicization of imperial pasts. More importantly, the works studied offer revised blueprints and theorizations of decolonial knowledge, subaltern collaboration, revolutionary internationalism, and anti-imperial culture. 


\section{Empire, Postcoloniality, and Decolonial Politics}

Before going any further into the topic of imperialism, the analyses drawn here in relation to the literary and historical objects of study operate under a particular conceptualization of Empire. The term is often used in critical theory circles as a sort of umbrella word for Western political, economic, and cultural hegemony; as both a period of history inaugurated by European colonial expansion and the means of establishing and maintaining politically, economically, and militarily - such a global form of power and status quo. The attempt to locate the West, tracing its geographic parameters, is a task fraught with ambiguities. After all, the West is, to quote Édouard Glissant, 'a project, not a place' (2). The same can be said of other related geographical configurations of global power, such as North/ South and the Cold War divisions of First, Second, and Third Worlds. It is upon Glissant's premise that I think through Empire as a project of power spawned from a particular time and place - European expansion circa the fifteenth century - but whose discursive grounds began to take shape centuries earlier through notions of normativity, universality, and racial/ ethnic otherness especially in regard to the cultural and political formation of Europe.

In America's Shadow: An Anatomy of Empire, William Spanos traces Western imperialist endeavors to ancient Rome, while Amílcar Cabral conceptualizes imperialism through production, the search for labor, and modes of transportation that 'eliminat[ed] the isolation of human groups within one area, of areas within one continent, and between continents' (94). In this regard, the foundations of Empire were 'evident at the time of the Punic voyages and in the Greek colonization, and was accentuated by maritime discoveries, the invention of the steam engine and the discovery of electricity' (94). Though many theorists and thinkers of Western imperialism have attempted it, pinpointing an exact moment of the dawn of Empire, or even arguing for one, is beyond the scope of this project and outside of my conceptualization of Empire.

Approaching Empire as a web of global power rather than a locatable entity avoids taking the aforementioned divisions of East/West, North/ South, First World/Third World as social and cultural essences. Rather, Empire speaks to a practice of social order that informs local (as in the social compartmentalization of cities), national (i.e. de jure and de facto disenfranchisement), and transnational (flow of capital, commodities, and people) power. In other words, Empire here also concerns the formation of postcolonial nationhood regardless of geographic location as much as it does complicity in the contemporary global economy. 
The aspects of Empire most central to the current project concern the aforementioned discursive bases and byproducts of contemporary power. Empire is approached throughout this project as a 'global practice of power' in the words of Partha Chatterjee (Black Hole 1). Empire is, moreover, a field of meaning within which such a practice is couched, potentiated, and reproduced through signifiers and notions of race, class, gender, sexuality, age, and (dis)ability. The literary works examined here prompt us to think of these as imperial categories of normativity and alterity that converge to form Empire's field of power and subalternity as, more specifically, a spectrum of subject positions. As such, Empire can be thought of, moreover, as both a subject-constituted, and subject-constituting, field. Empire, in its ideological existence, necessarily formulates its subjects through a particular economy of desire in which Empire's desire for reproduction is circuited to that of its interpellated subjects. To speak of the ideological core of Empire is, furthermore, to speak of its historicizing function, its narration of global time and space according to the aforementioned categories of life and geographies, thus forming an imperial realm of knowledge that classifies and places individuals as subject positions within Empire's system of meaning and power.

The term 'Empire' is merely one piece of the theoretical nomenclature constituting this project's framework. The majority of literary works discussed here can be considered postcolonial, in the strict temporal sense of a time period following formal decolonization. More than simply couched in a temporal space, these works are postcolonial as they reflect on the legacies and discursive foundations of colonial power. In this regard, through characters and/or narrative missions, they target the signifying field of Empire as one that has been reproduced for centuries up to the present. In other words, as Paulo de Medeiros succinctly puts it: 'Postcolonial time is always already unhinged, the postcolonial is not a condition of independence, it does not come after, as its prefix would suggest, but rather is always there from the beginning of colonialism and as such marks the colonizer as much as the colonized' (44). In this sense, the postcolonial is first and foremost a space of critical reflection regarding the means by which Empire is experienced and reproduced. To be clear, the 'post' in 'postcolonial' is not, to quote Kwame Anthony Appiah, a 'ground-clearing motion' ('Is the Post- ?') but rather a critical distance, a space from which to interrogate Empire and its continued ramifications.

This has informed the history of postcolonial theory, as a theoretically eclectic mode of inquiry into the reproduction of Western imperial power, of which colonialism was merely a part. The term 'postcolonial' does not, therefore, suggest a temporal break, but a call to interrogate and 
challenge the continuities of Empire. The theoretical scope of the project at hand looks to unite various schools of anti-imperial thought, especially postcolonial theory and decolonial studies. Despite supposed differences in historical frameworks regarding Western expansion and modernity, as well as in nomenclature, both have profoundly informed my conceptualization of Empire. Both, moreover, share crucial insights, through different critical lexicons, into the reproduction of and resistance to imperial power. Following the cues offered by the literary texts under consideration here, theoretical work from both schools pertaining to the subject within imperial signification will be of particular import. Although many of the issues related to Empire have been interrogated by other theorists and scholars, my framework of Empire also seeks to bring them together under a theoretical heading that also serves to identify a common target of critique, analysis, and resistance.

The texts studied in this volume are thus postcolonial both in the sense of being produced after formal decolonization and in their critical engagement with Empire. To be clear, the authors examined do not offer economic or military modes of reversing imperial power. Instead, they grapple with Empire's field of meaning and knowledge; offering new ways of theorizing how this field is reproduced while also imagining non-imperial means of signifying self, time, space, bodies, and objects.

This stance taken by the authors studied, which the title calls 'anti-Empire,' is deeply related to another theoretical term referenced in the title - 'decoloniality,' which in many ways names both the grappling with Empire as well as the gesture and struggle to move beyond and dismantle it. As a branch of critical theory, decoloniality/decolonial studies has been most developed, among others, by Walter D. Mignolo, beginning in his Local Histories/Global Designs: Coloniality, Subaltern Knowledges, and Border Thinking (2000). As the title of the present volume indicates, decoloniality articulates a political stance and site of knowledge against the modern, colonially constructed concentration of political, economic, and epistemological power. Decoloniality thus serves as response to what Aníbal Quijano called the 'coloniality of power' (532), mainly in regard to the race-based Eurocentric structure of power (the maintenance of a small white elite) in Latin America, stemming from Eurocentric epistemologies operating in tandem with the early modern elaborations of global capitalism. In this regard, the theoretical foundations of decolonial thought have largely diverged from the nomenclature of postcolonial theory, arguing that the Americas continue to be colonial.

Beginning roughly in the early 1990s (although his work in previous decades led up to it), Quijano's conception of coloniality as the structuring 
force of Latin American societies ${ }^{3}$ underscored the continuity of colonial forms of power based on race-derived divisions of labor within the post-independent nation and the relationship between these divisions and Latin America's place on the periphery of global systems of capital. This divergence is due less to an incomplete understanding of the postcolonial theoretical approach as a historical fallacy than to a concentrated laboring toward non-imperial modes of knowledge and signifying of time and space. In dialoguing across the work of Quijano and that of Enrique Dussel, Mignolo expands the concept of 'coloniality of power' in his 2001 essay 'Coloniality of Power and Subalternity' in The Latin American Subaltern Studies Reader, in order to understand the transitions from colonial occupation to late capitalism.

Dialoguing heavily with the work of Ranajit Guha, a founding member of the Subaltern Studies Collective, Mignolo qualifies coloniality as 'a structure of power in the (modern/colonial) interstate system' ('Coloniality' 430). In the case of Latin America, its peripheral role in the interstate system of capitalism, both colonial and contemporary, is predicated on the concentration of power among a small white elite benefitting from and serving the interests of capital. As the title of his aforementioned book suggests, coloniality is both global and constructed locally under overlapping structures of power. Due to the continuity of coloniality in the racialized division of labor and knowledge, the term 'postcolonial' is often rejected as an adjective for Latin American nation-states, in favor of the term 'colonial' in order to more emphatically convey Latin America's un-emancipated place in late capitalism.

In many ways, Mignolo's postulated relationship between Latin America's nation-states and global power echoes Chatterjee's concerns regarding 'an inherent contradictoriness in nationalist thinking, because it reasons within a framework of knowledge whose representational structure corresponds to the very structure of power nationalist thought seeks to repudiate' (Nationalist Thought 38). Beyond the nation, and in relation to it, Chatterjee later warns: 'the framework of global modernity will, it seems to me, inevitably structure the world according to a pattern that is profoundly colonial' (Empire and Nation 177). The term neo-imperial is still relevant to both decolonial and postcolonial critiques, pointing to relations of power

3 See Quijano's articles 'Colonialidad y modernidad/racionalidad,' 'Colonialidad, poder, cultura y conocimiento en América Latina,' and 'Colonialidad y clasificación social.' One can find a concern with these topics in his work leading up to the coining of the term 'coloniality,' namely in Nacionalismo, neoimperialismo y militarismo en el Perú and Imperialismo y marginalidad en América Latina. 
beyond national societies and states, namely the relationship between these and global economic and political forces.

The current project is not interested, moreover, in one of the fundamental debates between decolonial scholars and mainstream postcolonial thought, namely the temporal precedence given to the coloniality/decoloniality theoretical paradigm over what is understood to be a postcolonial analysis. The crux of this argument among decolonial scholars concerns a reading of anglophone and francophone theorists - Edward Said being the most common target - as positing the Enlightenment and the eighteenth century as a starting point of European colonial discourse on otherness, namely the advent of orientalism as an imperial area of study, cultural production, and projection of power. In response, Mignolo argues that it was the colonization of what became known as the Americas, especially that of Latin America by the Spanish and the Portuguese, which provided the discursive foundations for post-Enlightenment imperial epistemology. In this regard, Mignolo posits 'Occidentalism as the overarching imaginary of the modern/colonial world system' (Local Histories 20). Like the theoretical and historical pitfall mentioned above, which I have chosen to sidestep, this argument looks to pinpoint a moment in which Western imperial power is structurally consolidated and ushered in through the positing of European/Western knowledge and signification as the monological voice of time and space. My own conceptualization of Empire is much less concerned with reaching the end (or beginning) of the genealogy of imperial power and meaning. Empire, as a theoretical concept, operates under the awareness that the imperial field of meaning, and especially the discourses of otherness that undergird it, have been reproduced throughout the numerous sequences of territorial conquest, movements of bodies and commodities, and corporal oppression that have marked human history.

This current project is far more interested in decoloniality's focus on the coloniality of power, namely the realm of knowledge that undergirds it. Drawing on Quijano, Nelson Maldonado-Torres offers a succinct definition of coloniality as referring to 'long-standing patterns of power that emerged as a result of colonialism, but that define culture, labor, intersubjective relations, and knowledge production well beyond the strict limits of colonial administration' (243). These parameters of coloniality are inevitably similar to those of the conceptualization of Empire at work in the current volume. Maldonado-Torres especially has taken decoloniality and the study of coloniality in new directions, examining how coloniality constitutes different forms of being within its matrix of power. This, interestingly, leads Maldonado-Torres to examine coloniality through a Heideggerian lens. My conceptualization of Empire implies, rather, a materialist approach 
to imperial power, focusing on its core psychic relationship between signification and subjectivation.

In this sense, the conceptualization of Empire as a signifying field constitutive of subjectivity is, in many ways, akin to Antonio Gramsci's tracing of cultural hegemony as the fabric of social constructs and norms into which capitalist exploitation is embedded. This is, of course, Gramsci's revision of Marx and Engels's base and superstructure relationship. Interrogating and delinking the psychic workings of ideology inevitably leads to a dialogue with the theoretical work of Jacques Lacan, Louis Althusser, and Slavoj Žižek, as well as Jacques Derrida's problematizations of hegemonic signification. From here, the decolonial stances offered by the literary texts analyzed are interfaced with, and enriched by, the contributions of numerous theorists of colonial discourse, race, gender, and sexuality.

The concern with modes of knowledge at the heart of decolonial studies and the focus on signification within postcolonial theory are particularly relevant to the scope of this project and to the writers studied. An important precursor to the development of decolonial studies, over the decades, even prior to what would be considered its foundational texts (i.e. C. L. R. James's The Black Jacobins, Fanon's Black Skin, White Masks and Albert Memmi's The Colonizer and the Colonized), postcolonial theory has provided a much-needed critical idiom through which to grapple with the inner workings of Western imperialism and its modus operandi in different locales and over diverse bodies. This includes not only the legacies of this history but also how the discourses of imperialism regarding time, space, bodies, and objects continue to inform today's realities. This critical task became evident, of course, far before the term 'postcolonial studies' was officialized in academic parlance. Dissecting and challenging Empire from varying subaltern subject positions has been evident throughout the centuries of imperial power leading up to the founding voices of anti-colonial inquiry being subsumed into postcolonial studies as an academic inter- and multidisciplinary lexicon.

As its own critical idiom and mode of delinking, in my mind decolonial studies emerges not in opposition to postcolonial theory, despite some divergent historical and geographic understandings, but from the critical and radical spirit of postcolonial thinkers. This is more than evident in the dialogues that decolonial scholars have engendered with the likes of Frantz Fanon, Édouard Glissant, and Abdelkebir Khatibi, among others. The urgency behind the birth of decolonial studies comes, moreover, from the dearth of critical approaches to the relationship between the present-day Americas (especially Latin America), the history of European expansion, modernity, and late capitalism.

Since the authors and literary works constituting the study at hand labor 
toward knowledges and forms of meaning that both challenge and move beyond Empire, it is important to interface these contributions with those of thinkers that have also dealt with the relationships between struggle and signification. In this regard, the pioneering theoretical work of the Subaltern Studies Collective, for instance, paramount to what would become postcolonial studies/theory, is of particular importance to the conceptualization of this project and to the anti-Empire approach. The examinations of sign-systems and power undertaken by Partha Chatterjee, Ranajit Guha, Dipesh Chakrabarty, and several others provide both crucial inroads into the study of colonial discourse and a crucial theoretical lexicon with which to understand Empire through the central relationship between power and historiography.

Through her frequent collaborations and dialogues with the collective, Gayatri Spivak brings forth a deconstructionist approach to imperial historiography as a sign-system - a field of meanings constructed by and for the objectives of domination. This focus on meanings and imperial power also undergirds Edward Said's Orientalism, published in 1978, four years prior to the first volume of Subaltern Studies, albeit through a more consistently Foucauldian lens. In many ways, the collective understood the realm of meaning as a starting point for a shift in social order to be brought on by a simultaneous challenging of dominant historiography and a recovering of subaltern historicizing voices and texts, which could interrupt hegemony.

Spivak further elaborates on the relationships between shifts in sign-function and existent hegemony: 'The change in signification-function supplements the previous function' (In Other Worlds 197-98). Theoretically stranded in the reproductive circle of hegemony, it is no wonder Spivak looked to subaltern studies for 'a theory of change' in addition to 'a theory of consciousness' (198). The reading of Empire proposed here looks deeper into the production of signs, at the level of desire where subjectivation and power are tied together.

It is precisely the relationship between signification and subjectivation that the texts examined here further deconstruct while also gesturing toward an ethics of signification (the production of meaning) that eludes imperial forms of signifying time, space, bodies, and objects. In this regard, the current project operates as a follow-up to my first book, Subjectivity and the Reproduction of Imperial Power: Empire's Individuals (2015). Where the latter looked to offer in-depth analysis of the reproduction of Western hegemony via the repeated formation of the subject, Anti-Empire fills a gap in the previous project by exploring how particular writers have imagined modes of combatting Empire and of living outside of it. Many of the writers studied here offer new ways of knowing, political and epistemological stances that dovetail with Mignolo's 
interest in decolonial forms of knowledge. In this regard, the literary texts prompt us to dialogue with Mignolo's theoretical development and locations of decolonial epistemologies, from 'border gnosis' in Local Histories/Global Designs to his calls for delinking from imperial knowledge and 'unlearning' in his Darker Side of Modernity and Learning to Unlearn: Decolonial Reflections from Eurasia and the Americas (co-written with Madina V. Tlostanova).

This points to the larger contributions to decoloniality offered by the texts: intricate performances of delinking in the sense of a political stance against imperial knowledge as well as that of deconstructing the ideological and epistemological links which allow Empire to reproduce itself. In doing so, it is worth noting here at the outset that the political richness of the texts operates through largely poststructuralist leanings. These, however, lead us to dialogues across critical theories that allow us, in turn, to take decoloniality in new directions. In other words, the texts examined here offer new theoretical perspectives and contributions to decolonial studies by making a claim for a materialist and poststructuralist thread to the field, centering on the subject and the textualities of Empire and coloniality. In response to Empire's signifying field, the writers studied here point out modes of disrupting Empire's dialectic of subjectivity and signification while also interrogating it, engendering sites of counter-imperial knowledge and scenes of writing that emerge as a consequence of Empire, and subsequently chart modes of decolonial signification and selfhood.

Such an enunciation of a decolonial sign-system furthers the underlying epistemological mission of decolonial studies - decentering Eurocentric knowledge while gesturing toward global understandings through non-Western and/or subaltern modes of knowledge and postcolonial experiences. It is worth noting that numerous scholars and thinkers who identify with decolonial studies have enriched this field of inquiry by consistently opening important dialogues with postcolonial theorists, such as those mentioned above, and anti-colonial thinkers across disciplines, such as scholars of late capitalism (like Immanuel Wallerstein and Boaventura de Sousa Santos) and European philosophy (such as Martin Heidegger, Jean-Paul Sartre, and Etienne Balibar). Such dialogues underscore the transdisciplinary nature of the field and the need to interrogate coloniality as the intersectional product of the formation of modern capitalism, postcolonial dependency, Western forms of knowledge, and subsequent notions of human superiority and inferiority. The current project follows a similar trajectory while focusing particularly on the geopolitics of knowledge in relation to Western historicization. In other words, the chapters that follow explore the possibilities of non-hegemonic historicities - and, by extension, non-imperial subjectivations - rooted in subaltern knowledges. To be clear, 
these are not precolonial knowledges, but rather sites of knowing produced by the imperial processes of exploitation and signification. They are, in other words, scenes of writing and knowing that aim to counter, reformulate, or reorder the episteme and field of meaning into which they have been inserted. In short, we can think of the decolonial/anti-imperial works studied here (with the exceptions of those in chapters 5 and 6), as examples of what Boaventura de Sousa Santos calls 'epistemologies of the South,' which he defined as:

non-Western understandings of the world, for example, decisive cultural and political experiences and initiatives in the countries of the global South. This is the case of movements or grammars of resistance that have been emerging against oppression, marginalization, and exclusion. (Epistemologies 21)

It is in this regard - namely in terms of his call for non-Western understandings of time, space, and bodies - that Santos's work overlaps with that of many decolonial scholars. Ramón Grosfoguel, for instance, highlights Santos's gesture toward 'descolonizar las ciencias sociales de su sesgo eurocentrico' ['decolonizing the social sciences from their Eurocentric bias'] (104). Revising the social sciences would mean centering the experiences and sites of knowledge of those that have been systemically marginalized through the epistemic, economic, and political processes of Empire.

Antropofagia ['anthropophagy, cannibalism'], the avant-garde Brazilian cultural movement of the 1920s, examined in chapters 1 and 2, offers an early yet limited example of the aforementioned decolonial prerogative. The mission of formulating a decolonial scene of writing (and knowing) through which to resignify the nation, and beyond, was very much a point of heated debate among the movement's participants. Part of Brazilian modernism, members of the group, through different artistic mediums, developed nuanced reflections on Brazil's place in industrial global capitalism in connection with its colonial history and imperial European discourses on Latin American otherness and Western selfhood. The name of the movement, 'anthropophagy,' served as a metaphor for the appropriation and alteration of European cultural forms and philosophy through which particular tenets of modernity would also be revised.

As we shall explore in chapters 1 and 2, some participants, or indeed a faction of the movement, equated a precolonial fantasy of non-Europeanness and indigeneity - the case of the Tupi or the Anta - as the fulcrum of a postcolonial, non-European, national identity. Others, though, such as Mário and Oswald de Andrade (especially the former), disagreed with the 
search for a precolonial site of knowledge that was, in itself, only knowable through European exoticized narratives of South American indigeneity. In the postcolonial projects of both Mário and Oswald there is (perhaps to varying degrees), I argue, a refusal to appropriate such exoticist tropes and thus reproduce the same cultural silencing of indigenous peoples of Latin America. Doing so would once again reduce a site of knowledge (which is inaccessible to them) to an object of imperial knowledge. In their stance, we can grasp the argument that decolonial and anti-imperial modes of knowledge must not come from cultural elites. It is in this respect that I disagree with a common, but not completely unjustified reading of Antropofagia as reproducing Eurocentric consumption and articulation of indigenous otherness.

As different chapters will propose, decolonial knowledges and sites of signification emerge and interact dialogically with other forms of knowing. This is what Santos refers to as 'interknowledge' (188), a product of the circulation of sites of knowing within 'the ecology of knowledges confront[ing] the logic of the monoculture of scientific knowledge' (188). For writers such as Fernando Sylvan (Chapter 3), Luís Cardoso (Chapter 4), Olinda Beja (Chapter 7), and Mário Lúcio Sousa (Chapter 8), decolonial knowledge and signification is a persistent project beyond monocultural limitations such as those of nation, language, and locale. For them, the struggle against monoculturalism and monologicism, the philosophical foundations of Empire, must be perpetually fought. Although chapters 5 and 6 discuss literary works that have become part of a metropolitan literature, they too combat monologicism and some of the dominant narratives of Empire. The writers involved, Isabela Figueiredo and António Lobo Antunes, tackle Empire while having both benefitted and suffered particular traumas from their implication and participation in the reproduction of imperial power. Borrowing Santos's terminology, the writers and works explored here form an ecology of experiences within Empire, and offer different vantage points within the spectrum of privilege and subalternity. The fundamental commonality that brings them together is the experience of Empire, as different and multifaceted as such experiences are.

What follows is by no means intended to be an exhaustive exploration of decolonial possibilities. Rather, the literary works under examination present a diverse collection of experiences of Empire, including former colonists, current members of the African diaspora, and those displaced as a result of Empire-driven conflicts. At another level, some texts gauge Empire through elements of the fantastic, as is the case with Mário de Andrade's Macunaíma: o Herói sem Nenhum Caráter ['Macunaíma: A Hero without a Character'] and Mário Lúcio Sousa's O Novissimo Testamento ['The Newest 
Testament']. The common thread, I argue, is a shared interest in devising new modes of meaning-production that emerge through experiences of exile, diaspora, colonization, and the consumption of otherness. These modes simultaneously reveal the gaps and voids of Empire and imperial historicization while also proposing decolonial modes of knowledge and signification of time, space, bodies, and objects.

\section{Decolonizing 'Lusophone': An Attempt at Moving Past a Problematic Signifier}

The final key term of the title and scope of the project is 'Lusophone literatures.' Such a cultural-linguistic heading inevitably carries significant historical weight. As far as possible, the literary exploration carried out here does not interrogate these works as part of a collective entity sharing a phantasmatic cultural commonality. Such a problematic prerogative has been central to contemporary retracings of Portugal's colonial map under the guise of language and history, as is the case with 'Lusofonia,' Boaventura de Sousa Santos's 'time-space of official Portuguese language' ('Between' 71), and João Pina-Cabral's 'Lusotopia' ('Lusotopia como Ecumene'). Santos's essay is arguably well-intentioned, calling for a subaltern globalization and emancipatory counter-narrative in which Portuguese-speaking identities may participate; not only those identities of former colonies, but even those of the metropolis due to Portugal's imperial subalternity vis-à-vis northwestern Europe, especially England.

Ana Paula Ferreira cogently points out Santos's incomplete historicization of the 'time-space of official Portugal language,' - the failure to recognize the imbalances in subalternity and power contained within this 'time-space' as well as the erasure of non-white resistance from counter-hegemonic proposals such as that of Santos: 'It is the same subtle racism that lurks behind and continues to support the idea that there is such a thing as a common, somewhat fixed ground of language, Portuguese, bringing together a myriad of temporally and locally diverse colonizers and colonized' ('Specifity' 37). Ferreira's rebuttal to Santos also underscores the role of racism that is both occulted by and propels such language-based narratives. The fact that such global propositions emanate from the former metropolis, speaking for former colonized spaces and identities, reveals the continued metropolitan centrality (especially in terms of knowledge) and its understanding of former colonies as appropriable others. These calls for transnational collectivities are, in other words, often grounded in imperial meanings pertaining to racial and cultural difference, in addition to metropolitan imperial nostalgia. 
At the same time, both the texts analyzed and the current volume itself go beyond - and in doing so, refute - any particularities of Portuguese colonialism; particularities that have become integral to the aforementioned metropolitan cartographies. The decolonial projects undertaken by the writers examined here apply to the reproductive logic of Empire within which European national imperial projects are couched. These literary works further problematize such postcolonial transnational Lusophone entities in different ways, by focusing on the violent power dynamics of Empire that have spawned such neocolonial cartographies as well as the interrelated forces of signification that foment them. These forces include the role of academia not only in the propagation of carving the world, cultural production, and sociological issues into geo-linguistic slices, but also in studying these persistently articulated fragments through uncritical lenses.

The geographic scope of the project and its exploration of Lusophone literatures nonetheless reproduce what I aim to refute - a postcolonial collective and narrative of diverse geographic spaces and identities that share a common historical thread of having been colonized by a particular European nation. What is more, as a member of academia situated in the global North, I - and my work - circulate within a division of academic disciplines (namely those pertaining to the study of languages and cultural production) that also retrace imperial maps. This may be a moment to spark, once more, a discussion on the rethinking of academic disciplines, so deeply intertwined with the development of imperial forms of knowledge. While the case of anthropology, for instance, is well known, the geo-linguistic categories within area studies and language departments in higher education also demand critical attention. Although such departments are increasingly interdisciplinary and their members utilize a diverse array of analytical approaches, disciplinary focus and critical frameworks are often filtered, if not compromised, by rigid geo-cultural and linguistic boundaries.

What I hope to communicate by placing this project within what we may call 'Lusophone cultural studies,' but dialoguing with theorists and thinkers of non-Lusophone social and cultural backgrounds, is that postcolonial experiences in former Portuguese colonies, and indeed the metropolis, are not always particular to these locations. This inclination, or prerogative even, is very much prompted by many of the writers under analysis, as they go beyond nation and Lusophone spaces, although some of the themes and issued raised, such as intersectionality, offer new ways of understanding the Portuguese imperial project. Part of their decolonial positions, I argue, is the search and elaboration of new collective identitarian terrains that elude the centrality of nation, postcolony, and language. With some writers examined here, there is an overlap between being decolonial and being postnational. 
This subsequent dialogue between experiences of Empire also leads us away from situating specificities of Portuguese colonialism as central to notions of what some may call Lusophone postcolonialism. Indeed, the reproduction of Portuguese imperial power and the coloniality of power in Lusophone postcolonies often hinged on particular exceptionalist narratives based on discourses of race, gender, sexuality, and class. Lusotropicalism and the myths of racial democracy and the three races immediately come to mind. As Edward Said reminds us, 'every empire [...] tells itself and the world that it is unlike all other empires, that its mission is not to plunder but to educate and liberate' (Los Angeles Times). In other words, Lusotropicalism and the myth of racial democracy, like the 'white man's burden' and the United States as 'exporter of democracy,' are fundamentally examples of the stories which the coloniality of power/Empire tells of itself. Such stories that impact how power and subalternity are interpreted and experienced in Lusophone geographies offer important theoretical insights into the study of imperial modes of power. These particular exceptionalist narratives, so often posited as the 'difference' of Portuguese colonialism, should not, as Luís Madureira crucially warns us, become the 'difference' of Lusophone or Portuguese postcolonialism ('Difference' 135-41). It is equally important to avoid making these particularities emblematic of a 'Lusophone world,' while being cognizant of the role of these exceptionalist narratives in the conceptualization of problematic neocolonial transnational headings such as Lusofonia and the 'Lusophone world.' Exceptionalist myths such as those mentioned above have been challenged by subject positions that have experienced their repercussions. Scholars, intellectuals, organizers, and activists from across Portuguese-speaking spaces, such as Alda Espírito Santo, Abdias do Nascimento, Fernando Sylvan, Amílcar Cabral, and João Paulo N'Ganga, have often contested these myths by tackling Lusophone expressions of power in dialogue with other locales and as part of a larger order of power. As Ferreira argues regarding some of these names, 'their symptomatic absence from academic circulation, even or first and foremost that presented under the explicit or implied brand of Postcolonial Studies (in Portuguese)' ('Specificity' 37) represents an example of the aforementioned 'subtle racism.'

Angolan journalist, scholar, and activist João Paulo N'Ganga, for instance, has dedicated much of his work to challenging dominant narratives of power - Portuguese, Angolan, and global. He notably founded the Portuguese chapter of SOS Racisme in 1998, and his book Preto no branco: a regra e a excepção (1995) explores systemic and cultural racism in contemporary Portuguese society in light of its past and present colonial ideologies. The book also discusses diversity and inequity in Portugal often in dialogue with 
international contexts such as Brazil and the United States, making clear for broad audiences, for instance, that a

sociedade multiracial, não é por si só, sinónimo de uma sociedade anti-racista. Tanto o Brasil como os E.U.A. são sociedades multirraciais, mas como se sabe, são sociedades culturalmente racistas, onde apesar da legislação estabelecer a igualdade de todos os cidadãos uns continuam, parafraseando George Orwell, a ser mais iguais do que outros.

[multiracial society is not in itself synonymous with an anti-racist society. Both Brazil and the United States are multiracial societies but, as we know, are culturally racist societies where some continue, to paraphrase George Orwell, to be more equal than others, despite legislation establishing the equality of all citizens.] $]^{4}$ (93)

Vinício de Sousa, in his aptly titled Racismo, opressão dos povos: Elementos para uma análise sócio-histórica em Portugal e no mundo [Racism and the Oppression of Peoples: Elements toward a Socio-Historical Analysis in Portugal and the World], offers perspectives on revolutionary internationalism as a mode of combatting not only Portuguese colonial forms of racism, but the larger artifice of Empire. In a similar, yet more radical expression, in one of his many anti-imperialist/anticapitalist songs, the Portuguese rapper of São Toméan descent, Valete (Keidje Lima), calls for a global subaltern movement:

Nós vestimos a farda de Xanana

E levamos drama do terceiro mundo à casa branca

Desfilamos com a mesma gana de tropas em Havana

E com a resistência sobre-humana dessa convicção cubana

Toma esta ira psicopata deste filho de Zapata

Activismo de vanguarda.

[We wear Xanana's uniform

and take Third World drama to the White House

we march with the same vigor of troops in Havana

and with the superhuman resistance of that Cuban conviction

feel this psychopathic ire of this son of Zapata

vanguardist activism.] ('Anti-Herói')

This particular passage, and the song 'Anti-Herói' ['Anti-Hero'] as a whole, enacts precisely what several of the literary works examined here propose: not only a call to action, but an anti-imperial sign-system, played out

4 All translations in this volume are my own unless otherwise indicated. 
by Valete through a collection of subaltern anti-imperial historical signs. These include symbols and agents from Portuguese-speaking locales (i.e. Xanana Gusmão, founding member of East Timor's independence movement Fretilin) integrated with Emiliano Zapata, Fidel Castro, Patrice Lumumba, and Martin Luther King, among others, all directed toward challenging the current global matrix of power.

To this end, the diverse theoretical frameworks deployed in Anti-Empire ensure that the experiences brought forth by the literary works analyzed are not strictly confined to a narrative of Lusophone postcolonialism. I prefer to highlight, instead, how they offer new understandings and contestations of the broader concentration and reproduction of power based on race, gender, class, sexuality, and (dis)ability. In this sense, one can argue that the project surreptitiously develops or operates under a theory of Lusophone postcolonialism - one that looks to complicate its own existence by urging us think of Lusophone (post)colonialism as more than just 'Lusophone' and refusing to foment divisions of postcoloniality based on European imperial maps. For Madureira, stubborn discussions on the particularities of Portuguese colonialism vis-à-vis Anglo-Saxon colonialism (at the heart of debates regarding the parameters of Lusophone postcolonialism) often obfuscate the fundamental focus of Postcolonial Studies as a discourse and field of inquiry. This would be to 'reconsider the history of slavery, racism, and colonization from the standpoint of those who endured its effects' ('Difference' 141). As Madureira explains in his response to the formulation of Portuguese postcolonialism by Boaventura de Sousa Santos and furthered by Paulo de Medeiros and Anthony Soares,

the differences in colonial history and administration were of scarce importance to anti-colonial revolutionaries for whom imperialism looked very much the same everywhere. Postcolonial critique tends to adopt a similar point of view because it identifies with the subject position of anti-colonial activists, not because it willfully ignores the heterogeneity of colonial history from the colonizer's perspective. ('Difference' 141)

Following Madureira's arguments, this project, inevitably tied to the intellectual heading 'Lusophone postcolonialism,' is grounded in experiences of subalternity within imperial spectrums of power primarily, and, secondarily, the narratives that emanated from and sustained this power. In a similar sense, the particularities of Portugal's imperialist narratives must be understood as 'commonalities that Portugal's peculiarly brutal colonial enterprise shares with those of the so-called 
Super-Prosperos' (Madureira 'Difference' 141). It is these commonalities, Madureira continues, that 'should underpin the elaboration of a Lusophone postcolonial theory positioned in and oriented toward the South' (141). In posing such an argument, Madureira was already calling for a Lusophone postcolonial theory that goes beyond the 'Lusophone.' As several historians have noted, the exceptionalist narratives of Portuguese colonialism, such as that of amicable colonial relations, aside from being part of other imperial projects, were not realities 'on the ground.' In this regard, this is precisely what the works analyzed in chapters 5 and 6 underscore through nuanced considerations on the role of exceptionalist imperial narratives and their relation to dominant historicities.

Taking a cue from the writers examined here, this study of Empire approaches the particular in order to imagine collectivities and terrains of resistance beyond the linguistic/historical particular. For many of these writers, such an approach is paramount to undoing Empire's signifying field. As such, the common ground I wish to establish among the diversity of literary works here is not the fact they are written in Portuguese as a consequence of Portuguese colonialism (as the title would suggest). Rather, the central element, that which is shared by the writers, is their engagement with Empire, their questioning of its discursive underpinnings, and their impetus toward de-silencing and de-marginalizing subaltern voices. Therefore, the guiding connection between these texts and writers is that which must remain the focus of both postcolonial studies and decolonial studies.

\section{The Decoloniality of Postnationalism}

As mentioned above, the works under analysis reveal, to varying degrees, postnational inclinations in their engagement with Empire. These works have nonetheless entered the market of literary consumption through the filtering and categorization of national literatures written in Portuguese. For some of the writers included here, especially those of East Timor and São Tomé and Príncipe, their liminal presence in such a market so heavily

5 To mention only a few notable historians and their works, Gerald Butler's Angola under the Portuguese: Myth and Reality (1978) arguably initiated the inquiries that have been carried on in different directions by, among others, Cláudia Castelo in her O Modo Português de Estar no Mundo: O Lusotropicalismo e a Ideologia Colonial Portuguesa (1933-1961), Miguel Jerónimo Bandeira's Livros Brancos Almas Negras: A 'Missão Civilizadora' do Colonialismo Português (1870-1930), and Roquinaldo Ferreira's Cross-Cultural Exchange in the Atlantic World: Angola and Brazil during the Era of the Slave Trade. 
concentrated on metropolitan and (increasingly) Brazilian readership and scholarship, resembles the marginalization which their respective postcolonies experienced during Portuguese colonialism. Within the space of production, circulation, consumption, and canonization of literatures written in Portuguese, some writers of former colonies have enjoyed greater visibility than others.

The importance of postcolonial national literatures seems to follow the importance and primacy of the then colonies in the Portuguese imperial imaginary and economic profile. In this sense, the greater degree of political and economic importance given to Angola and Mozambique during the twentieth century by the Portuguese state is arguably reflected in the contemporary predominance of Angolan and Mozambican writers on the bookshelves of metropolitan bookstores, physical or electronic. As I have argued elsewhere (in Subjectivity), literary celebration and canonization of postcolonial writers (working in Portuguese) occurs primarily through metropolitan and, increasingly, Brazilian readership. The flipside of this is the relative dearth of writers who identify, to varying degrees and in different ways, as East Timorese, São Toméan, Guinea-Bissauan, Goan, Macanese, and, to a lesser extent, Cape-Verdean. Race and gender play an equally important and related role in the metropolitan consumption of postcolonial literatures, as evidenced by consistently bestselling authors such as Mia Couto and José Eduardo Agualusa, children of white colonists of Mozambique and Angola, respectively. Black female writers such as Lília Momplé and Paulina Chiziane have had varying degrees of success and critical acclaim, but not comparable to Couto and Agualusa. ${ }^{6}$ Luís Cardoso, a contemporary writer from East Timor whose work is studied here, is by far the most acclaimed writer from his country.

The visibility of postcolonial writers in the metropolitan space of literary reproduction and consumption is, of course, contingent upon their subjective existence within colonial and neocolonial spectrums of privilege and subalternity. Education and literacy in the imperial language certainly speaks volumes in this regard, as schooling in Portuguese (primary through higher education) was and continues to be limited to a few socioeconomically privileged members of postcolonial societies. Writing in Portuguese reflects far more, however, such as the level of investment in education by the Portuguese state during colonialism, 'native' access to education, and the ideological content entailed by such an education, especially in terms of engendering and interpellating subjects of Empire, from colonists to assimilados [assimilated natives]. It is in this sense that the dearth of

6 For more on this discussion, see Silva, Subjectivity. 
writers (working in Portuguese) from some postcolonies reflects the sort of investment from the metropolis. Those former colonies that were most peripheral to Portuguese economic and political interests lacked state investment in education to even greater degrees. Subsequently, literacy in Portuguese in East Timor was limited to an elite even smaller than those of Mozambique and Angola. To be absolutely clear, this is not to lament the lack of colonial education. For formerly colonized peoples, this is always a double-edged sword. The 'weak' presence of an imperial language, and thus greater space afforded to local languages, comes with other challenges. In the literary sphere, success is measured by the consumption of the cultural product. Writing in a non-imperial language is unfortunately seen as less viable due to the smaller projected readership. This dilemma speaks to the unavoidable ubiquity of Empire in which cultural production and consumption continue to be profoundly impacted by the economic, ethnic, and linguistic structures of European expansion.

Despite marginal presences of Portuguese as an official and obligatory language during Portuguese colonialism, its presence (spoken or written) is now central to cultural reformulations of Portuguese imperialism, as in the case of Lusofonia. The prerogative of materially enriching the metropolis is now reformulated into the mission of enriching the Portuguese language, and Portuguese-speaking patrimony, through increasing the mechanical reproduction and consumption of global literatures written in Portuguese.

As a result, postcolonial national literatures written in Portuguese are placed by publishers, bookstores, and academic departments into narratives such as Lusofonia. Subsequently, once ensnared into such a narrative, the literary works in question gain visibility and acclaim through Lusofonia while also reproducing it. This also prompts the question of the desire behind metropolitan readership. Is the 'Literatura Lusófona' section of Portuguese bookstores, or publisher Caminho's series of postcolonial literatures 'Outras Margens' ('Other Margins'), sought after by readers interested in the global presence of the Portuguese language? Or are such readers interested in other nuances which these works may offer? Regardless of intent, the pleasure of metropolitan and global Northern readerships that fuels the transnational circulation of literary products continues to be problematic and, in many ways, compromises artistic freedom and freedom of artistic dissemination. In other words, within postcolonial late capitalism, global Northern consumption continues to have a deep impact on global Southern production.

In this sense, as imperial discourses and concentrations of power continue to be central to Lusofonia and transnational markets of cultural production and consumption, the postnational decolonial stances taken 
by some of the writers here become increasingly important. Such gestures beyond nation, especially in the cases of Fernando Sylvan, Luís Cardoso, and Olinda Beja, mark a different kind of postcolonial literary enunciation. Significant scholarly attention has been paid to how postcolonial Lusophone writers have participated in the cultural process of nation-building and national identity. In the spirit of Robert Stam and Ella Shohat's assessment that 'nation-state-based analyses, in sum, are inadequate to the multidirectional traffic of ideas' (293), the texts examined here mark a shift that targets the political limitations of national frameworks for community $v i s-\grave{a}$-vis Empire while looking to forge decolonial modes of consciousness beyond nation.

Like the goal of many anti-colonial and anticapitalist cultural movements, the engendering of new modes of transnational consciousness implies the formation of a postnational/decolonial readership that can be perpetuated in parallel with decolonial production. This is precisely what some writers read here envision through the construction of a decolonial sign-system, a significational field that conceptualizes new collectivities based on diverse subaltern experiences while interrogating the foundations of Empire. For artistic production to circulate within the proposed (and utopian) decolonial subject-constituting field, the desire behind production must match the decolonial desire behind consumption to some degree.

In some cases, this imperative is already underway at the level of the postcolony, where modes of mechanical cultural reproduction and consumption are tentatively stripped from the former metropolis. An example of this would be Kusimon, the first private Guinea-Bissauan press of national and international literature, publishing works in Portuguese and Guinea-Bissauan Kriol. Although limited to the nation, Kusimon represents a step toward autonomous, anti-imperial cultural production. It has, of course, followed in the footsteps of other private or state-owned publishers across postcolonial geographies. Nonetheless, the postnational mission brought forth by the writers and texts here would demand us to go further, arguing, as did Said, that the nation is merely a step toward autonomy that must also be thoroughly questioned.

\section{Chapter Breakdown}

The volume begins with an exploration of the decolonial possibilities in works produced by the Brazilian Modernist movement of the early twentieth century, Antropofagia - namely key works by its most acclaimed writers, Mário de Andrade and Oswald de Andrade. The first chapter, 'Decolonizing Consumption and Postcoloniality: A Theory of Allegory in 
Oswald de Andrade's Antropofagia,' interrogates what I argue to be a central aspect of the works and political project of the movement - the deployment of a particular mode of allegory, one of consumption. I explore this allegory of consumption beyond canonical readings of the movement's cannibal metaphor in relation to Oswald de Andrade's poetry collection Pau Brasil ['Brazilwood'], in addition to his seminal 'Manifesto Antropófago' ['Cannibal Manifesto'] (1928).

The cultural goal of this avant-garde movement has been largely read as a proposed blueprint for cultural production within the postcolonial periphery in the industrial/postindustrial capitalist world-system; a call for cultural production to metaphorically 'consume' European models, digest them, and reformulate them. I seek to go further, however, by interrogating the decolonial potential of such a self-conscious cultural project. In order to do so, the chapter proposes to read some of the movement's most important literary works in relation to the European texts and historicization to which they refer. This chapter is thus grounded in an analysis of the European historicization of Brazil and a theorization of Antropofagia's deployment of allegories of consumption as a response to European consumption and signification of otherness applied to Brazilian spaces and bodies.

I argue that, in utilizing allegories of consumption, or performing it themselves, these works by Oswald de Andrade have implications far beyond the re-evaluation of national identity. In this sense, I propose a reading that surpasses the scope of the nation in order to flesh out the parameters of what I argue to be a decolonial site of consumption from which delinking can take place. While anthropophagic consumption itself can potentially destabilize Western meaning, I trace out these works' call for a destabilized site of consumption that does not foreclose the emergence of other sites. This chapter also seeks to demonstrate how Oswald de Andrade put this brand of consumption into practice through his work during the lifetime of the Antropofagia movement (1922-30), starting with his own critical consumption of imperial history and exploring the implications of this consumption for thinking outside of Empire.

The following chapter, 'Mário de Andrade's Antropofagia and Macunaíma as Anti-Imperial Scene of Writing,' follows up on the first, exploring Mário's own deployment of the cannibal allegory in his novel Macunaima (1928), and then offering a rereading of the relationship between a particular chapter of the novel, titled 'Carta pras Icamiabas' ['Letter to the Icamiabas'], and the novel as a whole. This particular section of the novel stands out from the rest for a variety of reasons. Firstly, its prose, utilizing a Renaissance European register of Portuguese, is markedly different from the rest of the 
novel and its use of a strategically colloquial speech - one that supposedly reflected the everyday speech of Brazilian non-elites. Equally relevant is the fact that it is the only part of the novel narrated by Macunaíma. The letter comes after he reaches Sáo Paulo following his journey from the Amazon to the industrialized mega-city, and is addressed to the all-woman tribe of the Icamiabas, detailing what he finds in Sáo Paulo.

Readings of Macunaíma's letter have largely centered on its prose, analyzing it as an ironic critique of the distance between written and spoken Portuguese. This is certainly a component of the novel's cultural politics taken into account here. This chapter reads the 'Letter to the Icamiabas' as an act of decolonial historicization, pertaining to an established realm of meaning that governs socioeconomic life in the industrialized city. In doing so, from a critical distance embodied by his ironic and meta-linguistic prose, Macunaíma narrates the ethnic and social compartmentalization of the city, the exploitation of labor, and the Eurocentrism of bourgeois life. The act of consumption, and Antropofagia's use thereof, thus comes full circle. Through the letter, and Macunaíma's complex voice, Mário de Andrade offers a scene of writing from which to read the imperial spectrum of power. Through a dialogue across schools of critical theory, this chapter explores the contours and radical possibilities (and the shortcomings) of this proposed place of historicization.

At the same time, I argue that the letter provides an internal critique of the very Antropofagia movement of which Mário de Andrade was part, thus underscoring once more his own ambiguous relationship with the artistic collective. The tale of a subaltern that attains whiteness - with all its social implications - and becomes the signifying voice speaks all too well to the limitations of a group of cultural elites in expressing the contours of postcoloniality and postcolonial nationhood. In a similar vein of foreseeing the shortcomings of Antropofagia in terms of decolonial historicization, this chapter also reads the letter as a foretelling or warning of power's appropriation of the movement's cultural project, namely Getúlio Vargas's state-driven narrative of national multiracial hybridity, Gilberto Freyre's myth of racial democracy, and Plínio Salgado's right-wing Verde-Amarelismo movement.

The third chapter, 'Toward a Multicultural Ethics and Decolonial Meta-Identity in the Work of Fernando Sylvan,' reads different facets of one of East Timor's most prolific and impactful, yet understudied, writers. A poet and essayist, the writings of Fernando Sylvan (1917-93) contain deep ambiguities; at times openly anti-imperial, as is the case of his poem Mensagem do Terceiro Mundo ['Message from the Third World'] (1971) and essay collection O Racismo da Europa e a Paz no Mundo ['The Racism of 
Europe and World Peace'] (1964). On the other hand, another portion of his essayist production reveals an adherence to Portugal's late imperial narrative of a pluri-continental, multiracial nation. This is the case with Comunidade Pluri-Racial ['Pluri-Racial Community'] (1962) and Perspectiva de Nação Portuguesa ['Concept of the Portuguese Nation'] (1965).

In attempting to make sense of this seeming contradiction, this chapter seeks to flesh out Sylvan's stance against Empire by interfacing his essayistic production with his poetry. For instance, in his O Racismo da Europa e a Paz no Mundo, written during the period of heightened anticolonial struggle in Africa and Asia, Sylvan offers a theorization and cursory genealogy of European and European-American global hegemony, ranging from Europe's historicization of itself as 'the standard civilization,' the fantasy of European superiority, and its resignification of difference in order to retain the balance of global power. This chapter thus contextualizes Sylvan's anti-imperial thought with that of postcolonial and decolonial thinkers such as Frantz Fanon, Aimé Césaire, and Enrique Dussel, in addition to elaborating the points where Sylvan's thought further problematizes and contributes to the theorization of contemporary global power.

In a related gesture, he lays out a particular call to action for 'os povos que viveram sujeitos a regimes coloniais' ['the peoples that have lived under colonial rule'] to break Empire's monologicism and forge new possibilities for humanity, especially to engender an alternative field of meaning with a dialogic mode of signifying bodies and spaces. It is in his poetry, I argue, that Sylvan puts into practice his path toward decolonizing intercultural meaning - freeing the way people come to know themselves and each other from Eurocentric discourses of difference. The chapter thus explores his interrogation of the possibilities of decolonial intercultural meaning by unpacking his tropes of global movement. Here one can find an articulation of what I call 'meta-identity': an experiment in the inauguration of a nascent anti-imperial subject, one that is in perpetual flux, thus avoiding notions of center and origin. The chapter explores the parameters of this centerless reality and origin-less journey through space by drawing on the works of Gayatri Spivak, Jacques Derrida, Rey Chow, and Jean-François Lyotard.

Chapter 4, 'Untranslatable Subalternity and Historicizing Empire's Enjoyment in Luís Cardoso's Requiem para o Navegador Solitário,' follows up on Sylvan's expository indictment of Empire's monologicism with an exploration of contemporary East Timorese writer Luís Cardoso's contributions to decolonial tropes of movement and meaning-making. Following a brief overview of Cardoso's larger œuvre, the chapter examines his 2007 novel, Requiem para o Navegador Solitário ['Requiem for the Solitary 
Sailor'], particularly the actions and experiences of its narrator, known only as Catarina. Born in Batavia, Dutch East Indies, to a Chinese father and Batavian mother, her arranged teenage marriage to a Portuguese port administrator of Dili leads her to move to the then colonial capital of Portuguese Timor. The novel's story unfolds between the mid-1930s and the Japanese invasion of the island of Timor during World War II in 1941, while Catarina is ensnared by imperial actions both local and global.

As narrator, though, she is able to historicize the actions around her and, most interestingly, the modes through which dominant historicization is carried out by imperial subjects in power. This chapter analyzes the critical reflections offered by Catarina's text on the ideological mechanisms at work behind the acts of violence which she endures. Following her rape at the hands of her fiancé, for example, she pinpoints the discursive underpinnings of interracial sex sanctioned for European men. The chapter takes this reflection further by deconstructing the gendered function of fantasy within Empire as well as the role of jouissance (Jacques Lacan's term for enjoyment beyond the explicit laws of the social realm) in the formation of masculine heteronormative identity.

A further and related component of this chapter resides in how Catarina conceptualizes her ability to produce meaning within and against Empire. Her reflections on her own experience as object of imperial knowledge leads her, I argue, toward a quest for what I call 'untranslatability.' The chapter develops this concept not in reference to a shift from one language to another, but to refer to an initiative that would impede Empire's production of knowledge - the way in which participants of Empire (such as port administrators, in this case) shift one signifier to another. Working with the term trasladar, the Portuguese and Spanish word for moving or shifting, I argue that Catarina's act of writing aims to prevents her being shifted from historicizing subject to object of imperial knowledge and fantasy. In this regard, the novel urges us to engage with the way in which power repeatedly produces meaning pertaining to othered bodies and through acts of violence perpetrated on them. The tension between writing against forces of power and being written by them is, I argue, central to the novel.

Chapter 5, 'Imperial Cryptonomy: Colonial Specters and Portuguese Exceptionalism in Isabela Figueiredo's Caderno de Memórias Coloniais,' turns attention to how contemporary metropolitan writers recollect colonial experiences in ways that challenge the reproduction of Empire while also offering new modes of understanding this reproduction. Many writers have interrogated the violence and different experiences contained within the five centuries of Portugal's imperial project. In Figueiredo's memoir one encounters a critical confrontation with mainstream metropolitan 
historicization. In opposition to a right-wing multicultural narrative of amicable Portuguese colonial relations supposedly devoid of racism, which is disseminated through visual media, sports journalism, and popular literature, Figueiredo relates her experience as a colonist in Mozambique, where she was born (in 1963) and resided until decolonization in 1974.

In opposing this mainstream narrative, she retells many of her traumatic experiences growing up in the colony, beginning with her formation as a gendered and racialized subject and the teaching of desire by her social and familial circles. In other words, she utilizes her own placement in Empire's discursive field to contest the metropolis's dominant post-imperial narrative regarding its colonial past. Of the different characters that emerge from her memoir, her father is undoubtedly the most prevalent. Figueiredo notably equates her father with colonialism, as the embodiment and voice of race-, gender-, and class-based power. The ubiquity of the father in her narrating of the past urges us to think of him as a specter, one that repeatedly destabilizes the present, both Figueiredo's and that of the former metropolis. This chapter utilizes Jacques Derrida's concept of spectrality in dialogue with his engagement with Maria Torok and Nicholas Abraham's notion of cryptonomy. The goal of this particular inquiry is to understand the ideological relationship between the fields of racial, socioeconomic, and sexual meaning experienced by Figueiredo as a colonist and the official political narrative of pluri-continentality and amicable colonialism promoted during and after the final three decades of Portuguese imperialism.

Through this approach, this chapter also attempts to better understand the impact of Figueiredo's memoir in the metropolitan public sphere and how she negotiates her own identity in relation to the racializing and gendering demands of imperial power. Through the aforementioned theoretical frameworks of cryptonomy and spectrality, in addition to interfaces with Walter Mignolo, Michel de Certeau, Judith Butler, Dana Luciano, and Jacques Lacan, this chapter maps Figueiredo's political project as the disentangling of the various layers of imperial narrativization regarding race, gender, sexuality, class, and metropolitan privilege.

Chapter 6, 'Spectrality as Decolonial Narrative Device for Colonial Experience in António Lobo Antunes's O Esplendor de Portugal,' continues the theoretical groundwork set by Chapter 5 in order to examine the anti-imperial function of spectrality in the work of acclaimed contemporary Portuguese writer António Lobo Antunes, particularly his 1997 novel O Esplendor de Portugal [The Splendor of Portugal]. Alongside José Saramago, Antunes is arguably the most revered Portuguese writer of the period following colonialism. A former military physician and conscript during 
Portugal's reactionary fight to counter anticolonial movements in Angola, Antunes's cuvre has offered scathing interrogations of the depths of Portuguese imperial ideology, Portugal's fascist/corporatist past, and the many forms of hate and violence that have undergirded particular views of Portuguese national identity, including racism and homophobia.

In relation to Antunes's earlier novels focused on Portugal's imperial past, such as Os Cus de Judas [South of Nowhere] (1979) and As Naus [The Return of the Caravels] (1988), O Esplendor de Portugal is, I argue, the earliest of Antunes's works that deploys spectrality as a consistent and developed narrative device - an aesthetic mode of narrating colonial experience and subjectivities ensnared within imperial discourses. At the heart of the novel is a colonial settler family's tri-generational experience in Angola. The novel is divided into three parts each centering on a different sibling, children of Isilda, a Portuguese colonist born and raised in Malanje, Angola, who resides there until her death. Each part contains ten chapters: five narrated by one of the now adult children residing in Portugal alternating with five narrated by Isilda. Each chapter begins with the date on which it is being articulated. All the chapters narrated by Isilda's children (Carlos, Rui, and Clarisse) are dated December 24, 1995, whereas Isilda's 15 chapters span two decades from Angolan independence up to the present. We soon come to learn that Isilda's chapters are actually letters she wrote to Carlos, with the possible exception of her last chapter, also the last of the book, which is dated December 24, 1995.

The narration of each chapter is, moreover, constantly interrupted by voices from the past that participated in the colonist experience, which incessantly interrupt the process of writing and the production of meaning. O Esplendor de Portugal demands that we engage with spectrality at both the level of writing and historicization - producing meaning in relation to particular events - and at the level of identity formation. In this regard, the novel offers profound reflections on the externality by which identity and subjectivity are formed within Empire. This leads the chapter to a theoretical exploration of the relationship between specters and the Freudian/Lacanian specular image or ideal ego through which an individual becomes a subject within ideology. From here, the novel also guides this chapter to yet another rethinking of Empire's different layers of meaning and power.

Chapter 7, 'Decolonizing Hybridity through Intersectionality and Diaspora in the Poetry of Olinda Beja,' explores how Beja, born in 1946 in the African archipelago of São Tomé and Príncipe, seeks to produce a signifying chain that emerges from the centuries-long impact of imperial power on the world, particularly on disenfranchised peoples and spaces. Beja goes a step further by reflecting on ways to enunciate identity and collective struggle 
in a decolonial fashion. The chapter reads select poems from three of her collections spanning her poetic trajectory and cuvre: Bô Tendê? ['Do You Understand?'] (1992), No Pais do Tchiloli [In the Country of Tchiloli] (1996), and Aromas de Cajamanga [Aromas of Ambarella] (2009). In doing so, we shall examine what we may call a decolonial remapping; one that Beja carries out, I argue, in a poetic narrating/signifying of movement through time and space that reorders imperial signifiers.

Beja notably begins this poetic exploration by reflecting on her interpellation as an African woman raised in the metropolis and the product of an interracial sexual union. From here, Beja gestures toward a decolonial consciousness that is explored by means of theoretically interfacing W. E. B. Du Bois's 'double-consciousness' with Kimberlé Williams Crenshaw's notion of 'intersectionality' speaking to the confluences of imperial categories of race, class, gender, sexuality, and international movement that impact experience within the modern spectrum of power. This decolonial consciousness forged intersectionally, as a mode of living and signifying the world while the signifying forces of Empire also do so, forces us to rethink a key, if not polemical, concept within postcolonial theory: hybridity. Drawing on Crenshaw and Du Bois, as well as Mignolo's dialogue with Du Bois, this chapter shifts the theoretical focus from interstices and interspaces between imperial categories to overlapping spaces of consciousness that permit their own postponement of meaning and subsequent ability to resignify time, space, and bodies in a decolonial fashion.

As I argue, Beja attempts to carry this out in her work in different ways, such as articulating time and space over and against historical markings of imperial violence. She does so, for instance, by evoking such signifiers in order to combat the imperial forces of historical erasure while also engendering a system of postcolonial meaning. Although her poetry contains profound explorations of national identity, for her such a project is not isolated from global forces. While she may be considered a São Toméan poet, Beja's poetry reveals her own diasporic experience through a broader form of political consciousness that attempts to connect different decolonial paths, projects, and forms of consciousness.

The final chapter, 'Transgendering Jesus: Mário Lúcio's O Novíssimo Testamento and the Dismantling of Imperial Categories,' examines how the novel combines the religious with elements of the fantastic in staging the reincarnation of Jesus Christ. The narrated events of the novel, taking place in the remote village of Lém on the island of Santiago, Cabo Verde during the early 1970s (the last years of Portuguese colonial rule), unfold when a devout Catholic elderly woman on her deathbed requests that a photograph be taken of her instead of summoning a medical professional. 
At the moment the photograph is taken, her body is transported into the camera. After developing the film, local residents witness the (Eurocentric) image of Christ superimposed upon her body, and the elderly woman, now known to be Jesus, is brought back to physical life. Jesus Christ, in other words, is reincarnated as an elderly African woman who has lived her life as such within Empire.

Placed within an existing field of global meanings, especially pertaining to notions of morality and propriety underpinned by racial and sexual discourses, Jesus confronts a world of stigma and suffering. As millions of people flock to Lém to seek out the messiah, many of them requesting miracles, Jesus comes face to face with imperial categorizations of bodies in terms not only of race and gender, but also of disease and disability. In doing so, she is forced to grapple with the construction and lived consequences of particular notions of normativity - of corporal ability, skin color, and gender - that inform privilege within Empire. The resolutions she seeks reveal a mission against what Michel Foucault and Gayatri Spivak call the epistemic violence of power, namely that of Empire.

Jesus in this Newest Testament is also repeatedly made aware of the ideological role which her position, as Christian messiah, has played in the current state of global power. She thus offers the reader a critical reflection of the economy of desire in which she must now maneuver. Her life as Jesus is above all a confrontation with hegemonic meanings: how she has been written in the Scriptures, as well as how the individuals with whom she comes into contact have been interpellated and placed within the existing power spectrum. Her interactions with the meanings imposed upon her, individuals, and spaces ultimately chart a decolonial path that is interrogated here. This entails a critical open-endedness against epistemic impositions and a gesture toward the undoing of imperial categories of otherness and normativity, as well as a questioning of gender binaries and the often violent performance of masculinity.

Each chapter thus examines works emerging from different locations and periods across the last century - a century that saw drastic political shifts tied to formal decolonization while also bearing witness to the insistence of Empire under new guises. What the works share, far more importantly than the language in which they are written, is a political impetus toward grappling with Empire, particularly its relationship between signification and subjectivation, while also imagining modes of contestation and decolonial forms of producing meaning and knowledge. These texts, and this project, thus contribute to an existing language of decoloniality, a lexicon through which to tackle Empire and to think toward anti-imperial signification, knowledge, and subjectivity. 


\section{Decolonizing Consumption and Postcoloniality: A Theory of Allegory in Oswald de Andrade's Antropofagia}

\section{Situating Antropofagia in Empire}

S everal decades before Fredric Jameson's essay 'Third World Literature $\mathcal{S}$ in the Era of Multinational Capitalism' set off a memorable and no less theoretically and culturally important debate on postcolonial literatures, the Modernist avant-garde movement in Brazil known as Antropofagia was already reflecting on the radical significational possibilities of the narrative form that was so central to the Jameson debate: allegory. In the early and mid-1920s, two of the movement's founders and greatest contributors, São Paulo natives Oswald de Andrade and Mário de Andrade (no relation), labored toward a new language of Brazilian nationhood that would both challenge and reassess the Eurocentric tendencies of Rio de Janeiro's cultural elites. The movement's official unveiling occurred during the week of modern arts in São Paulo in February of 1922 commemorating the centennial of Brazil's independence by showcasing contemporary art forms.

Carlos A. Jáuregui's succinct assessment of Antropofagia argues that it 'was not an academic movement, a theory of identity formation through consumption, or a social emancipation program' (22). Partially agreeing with Jáuregui's take, the movement was far too heterogeneous, particularly on the scale of radical politics, for one to comfortably label the work spawned by its participants as a cohesive entity. Even considering these discrepancies between contributors, the movement as a whole shared different pitfalls and shortcomings that trouble retrospective readings of the movement as an emancipatory and politically engaged set of counter-discourses. Attempting to retrieve intent from the work of cultural producers is, of course, a tricky and potentially problematic endeavor. On the other hand, and despite the intent of the producer, one can nonetheless extract insights and meanings from the work toward broader goals, all differing in their politics. In the case of Antropofagia, this has notably been done in the realm of academia, 
particularly by scholars of critical theory, and by the political state, namely the nationalist populism of Getúlio Vargas's Estado Novo [New State] regime (1937-45).

Despite its profound and undeniable problematics, which will be covered across this chapter and the next, much can be extracted from some anthropophagic works toward the goal of grasping the reproduction of Empire and contemplating modes of delinking its signifying chains. To be clear, Antropofagia was undoubtedly a precarious and imperfect bourgeois project with undeniable political shortcomings. Nonetheless, from some works, notably those of Oswald and Mário de Andrade, one can extrapolate particular contributions to decolonial thought and the study of Empire, part of an archive of intellectual history in Latin America that reaches the formation of decolonial studies. More than a shift in national articulation, portions of the anthropophagic project proposed a new scene of writing ambivalently divergent from, and critical of, the white bourgeois gaze that informed fin-de-siècle Rio de Janeiro's Tropical Belle Époque. This scene of writing was embodied in the very name of the movement - the cannibal metaphor of consuming the European other, including its scene of writing, and rewriting its signifiers into a re-historicized Brazil. More specifically, this new gaze articulates itself from the problematics of Brazil's colonial and early postcolonial history - appropriating rather than repressing the histories, violence suffered, and even agencies of native Amerindians, Afro-Brazilian slaves, and the industrial workers of Antropofagia's period. To deploy such a robust significational project, anthropophagists such as Mário and Oswald de Andrade turned to allegory throughout their work. Sidestepping Jameson's controversial generalization, this chapter aims to theorize the allegorical form within the postcolonial context as used in the fiction and thought of Antropofagia.

The movement's postcolonial concerns, interrogated below, did not discursively target merely Brazil's colonial period. Colonial discourse, and larger coloniality, is questioned throughout Oswald and Mário de Andrade's work through a sort of Bhabhan 'time-lag', 'a moment for revisions' (275) informing nationhood and structuring postcolonial society. Through this perspective we can further elaborate Bhabha's oft-cited concept as one suggesting that through the temporal break or Derridean postponement of the signified emerge not only 'new and hybrid agencies and articulations' (275), but also reinscriptions and reformulations of power. In this moment of significational collision - the anthropophagic moment - the renegotiation of colonial power into the nation via the maintenance of a colonial elite is contested 'at the level of the sign' (275) of nation. 
Antropofagia, as not only a project of cultural production but also a mode of cultural thought regarding global and local power dynamics, emerged in response to particular tendencies in Brazilian literature and art often couched in and reproducing such dynamics. Drawing on Bhabha's words above, we can think of the nation, in cultural production, political rhetoric, and social discourses, as the sign through which local tensions (such as class warfare and racial marginalization) are narrativized into global, often Eurocentric, frameworks of social organization. Antônio Cândido comes to a similar conclusion regarding the emergence of a Brazilian literature, duly structuring his Formacão da Literatura Brasileira ['Formation of Brazilian Literature'] as a study of this formation, 'como síntese de tendências universalistas e particularistas' ['as the synthesis of universalist and particularist tendencies'] (23). As Cândido suggests throughout his multivolume work, this synthesis is far from swift, often occulting various forms of violence and marginalizing voices while bestowing historical and social primacy upon others. This relationship between the universal and particular, or the historical reordering of the latter via the former, would come to inform Brazilian cultural and political elites' claims to modernity, carried out through European universalist notions of national progress.

Oswald de Andrade's 'Manifesto Antropófago' and Pau Brasil and Mário de Andrade's Macunaima yield historical readings that regard the particular and the universal as dialectical forces constituting power in Brazil and the nation's place within Empire. In these works to be studied in this chapter and the next, there is a consistent questioning, contestation, and playing with colonial forms of historicization from both within and without the postcolony. Oswald de Andrade's 'Manifesto Antropófago,' summarizing the goals of the movement, and even more so his collection Pau Brasil, offer nuanced examples of this.

Herein lies the anthropophagic logic of the cannibal metaphor for the contestation of coloniality: the consumption of dominant historicization and reformulation of that which historicizing subjects had hitherto consumed. This speaks to Antropofagia's twist on primitivism; one that consciously evokes native Amerindian imagery as a Eurocentrically derived text while subsequently shying away from celebrating and speaking for colonially marginalized identities such as those of Amerindians. Similarly, Oswald and Mario also tackle Eurocentric imperial notions of progress, economic structure, alterity, and political power. In this sense, their anthropophagic works dialogue well with the famous essay of Brazilian theorist Roberto Schwarz, 'As idéias fora do lugar' ['Ideas Out of Place'].

Often used as a framework by other scholars through which to question the deployment of European/universalist aesthetics to the postcolony, the 
titular phrase is, for Schwarz, far more politically inflected. For Schwarz, the fundamental 'out-of-place ideas' speak to the contours and philosophical underpinnings of the post-independence Brazilian state, namely the paradoxical espousal of Enlightenment political values pertaining to human rights while maintaining the institution of slavery and class structures based on various forms of dependence. Schwarz argues, in other words, that the profile of the postcolony, shaped by the political formation of the First Empire at the moment of independence, offered a narrative that could never correspond to reality nor to the lived experiences of exploitation under such a reality.

Schwarz's arguments therefore take those of Antônio Cândido even further: the postcolony, as a political entity and collection of subjectivities, is itself profoundly shaped by the application of universalist ideas to particular realities, the first often occulting and/or silencing the latter. In this regard, Schwarz calls our attention to a crucial example of coloniality at work in the advent of the postcolony. Through the framework of universal (read Western) values, national scenes of writing occupied by colonial political and cultural elites re-historicize social relations by attempting to place the present within a narrative of modern Western nationhood. As Schwarz would agree, this was merely the first problematic example of placing (or erasing) the particularities of exploitation into the modernity of the universal.

Through a tentative genealogy of the application of universalist ideas, Schwarz persistently ties such applications to the reproduction of power and privilege, which are central to the theorization of Empire throughout the present volume. For Schwarz, the dialectic of favor and dependence is arguably the moving force in this materialism of power and privilege; a dialectic by which the limited practice of social mobility is contingent upon sparse and selective favors emanating from positions of power to subaltern subjects. The extortive logic of this exchange tends naturally to imply a return of favors. Schwarz's view of social relations has often been read within Lusophone scholarly circles as pertaining to merely Brazilian realities, but Schwarz posits this dialectic as central to global realities of domination and subalternity, wrapped, of course, in discourses of universality. With regard to Europe, for instance, Schwarz postulates that 'o universalismo visara o privilégio feudal' ['universalism is guided by feudal privilege'] (17). Schwarz's focus in 'As idéias fora do lugar' is, nonetheless, on theorizing social relations of the Brazilian postcolony, regarding which he argues:

adotávamos sofregamente os [princípios] que a burguesia européia tinha elaborado contra arbítrio e escravidão; enquanto na prática, 
geralmente dos próprios debatedores, sustentado pelo latifúndio, o favor reafirmava sem descanso os sentimentos e as noçóes em que implica. O mesmo se passa no plano das instituiçóes, por exemplo com burocracia e justiça, que embora regidas pelo clientelismo, proclamavam as formas e teorias do estado burguês moderno. (17-18)

[we anxiously adopted the principles that the European bourgeoisie had elaborated against will and slavery; meanwhile, in practice, favors consistently reaffirmed the sentiments and notions within which large plantation owners were implicated. The same occurs at the institutional level, for example, with bureaucracy and justice which, although ruled by clientelism, looked to the forms and theories of the modern bourgeois state.]

The notion of 'ideas out of place' thus names the central contradictory logic of Brazilian modernity, referring specifically to the intermingling of post-Enlightenment universalist values with national institutions and everyday societal practices of dependence.

Antropofagia thus comes on the heels of numerous decades of this intermingling at the heart of the postcolony. To varying degrees, the movement sought to displace universalist ideas, articulated from Eurocentric scenes of writing, as failed modes of narrating and understanding the particular exigencies of the postcolony. In the articulation of Antropofagia's mission, namely the questioning of European cultural forms, there is an implied call for the questioning or remolding of the universal via the nuances of the particular, including an opening for the existence of alternative sites of signification within the particular. The intensity of such a project varied depending on the member of Antropofagia.

\section{Consumption of the Primitive}

Anthropophagic thought also approaches Empire in a global framework, namely regarding the trends of global dependency and the movement of industrial capital in the Antropofagistas' enunciatory present. Moreover, they articulate the problematics of postcoloniality within a globalized financial and cultural economy via diverse subject positions within the global periphery. In this regard, Oswald and Mário de Andrade circumvent the homogenization of difference into a generalizing binary - Jameson's primary pitfall which Aijaz Ahmad notably condemns: 'the enormous cultural heterogeneity of social formations within the so-called Third World is submerged within a singular identity of "experience" [of colonialism]' 
(104). K. David Jackson notably traces 'the origins of antropofagia [as] inseparable from contemporary European fascination with the primitive' (90). As a postcolonial nation on the periphery of global capital, as nation/ cultural sign, Brazil continued to be ensnared in the international field of Eurocentric imperial meaning. An object of European contemplation as tourist destination, Brazil continued to be signified from Europe - the universal site of imperial articulation and narrativization.

Brazilian cultural historian Alfredo Bosi points out a fundamental distinction that undergirds the work of Mário de Andrade, arguably the most nuanced participant in the Antropofagia movement; namely between the "primitivo histórico e o "primitivo" como pesquisa do homem que não pode deixar de ser, apesar de tudo, um homem integrado em uma dada cultura e em uma determinada civilização' ['historical primitive and the "primitive" as a site of research for the man who cannot cease to be integrated within a given culture and a particular civilization'] (400; emphasis original). Bosi's italicization of the 'historical primitive' arguably refers to the existence of a native subject uninscribed and unknowable to outside gazes and epistemes, in contrast to the primitive as object of imperial knowledge. This distinction echoes that which is later traced by Hélène Cixous and Catherine Clément between absolute Other and Other as an imperial text (71). In this regard, Mário de Andrade calibrates Antropofagia as a series of layers of consumption.

The scenes of writing sought by the movement, especially in Mário de Andrade's work, must then gauge, or consume, both the primitive and the postcolony as imperial texts, rather than inscribing fantasies of precolonial life through which to envision nationhood. For Kimberle López, this implies 'the turning of the imperial gaze toward his own people' (25). López also reminds us that 'it was the European Romantics' original valorization of the exotic that made Americans look at their own history in this fashion and, although they are American, the authors of these Romantic texts were still describing an ethnic Other' (26). Unlike Brazilian Romantics such as José Alencar, both Mário and Oswald de Andrade, I shall argue below, read primitivism more critically, calling for a consumption of their underlying imperial gaze and its primitivist texts through which they may be destabilized and reformulated. Such an undertaking is central to their larger project of constructing an open-ended site of consumption and meaning-production that reorders imperial historicities.

In examining this aspect of Antropofagia, it is crucial to consider some of the repercussions of European primitivist writings on Brazil, the tradition of which is long and laden with notable historical figures. While a thorough 
study of these is beyond the scope of the present project, such writings bring varying degrees of nuance to the history of European primitivism. This fascination with primitiveness pertained not only to Brazil's indigenous population, but also to its cities, particularly Rio de Janeiro, as un-European imitations of the culturally universal metropolis. European notions of primitiveness were not always, therefore, tied to one particular racialized compartment of the 'developing' nation. Rather, these notions constituted the epistemological optic through which imperial Europe was to understand the nation and the global South. The primitive, as a frame of otherness, served to signify the different geographies contained within postcolonial space. The narrativization of the global from the cultural place of Europe, specifically its bourgeois cosmopolitan and consumerist strata, presents (post)colonial space as more complex than a simple homogeneity that subsumes all otherness in opposition to European bourgeois whiteness. As Walter Mignolo argues regarding the cultural dynamics of cosmopolitanism, its 'point of origination [...] is the West, although its routes of dispersion encountered partisans beyond the Western history of ideas and political debates' (Darker Side 252).

The signification of Brazil from Europe produces its own form of hybridity in which the primitive is a floating signifier latched onto the different socioeconomic, racial, and cultural compartments of the nation. The primitive, and its associated cultural and racial lexicon (backwards, non-European, un-modern), came to signify even that which is typically opposed to primitiveness - such as industrialization, urban development, and other trends with temporal, supposedly, European/Western origins. From the European scene of writing in the twentieth century, difference becomes the frame through which to understand particular modes of sameness. In other words, primitiveness as a surplus of meaning essentially conveyed a deficit of sameness, thus rendering the tropical city undergoing rapid modernization insufficiently modern.

The cannibal metaphor arguably stems from, and is thus posited in reaction to, the European consumption of the (post)colonial other in the form of epistemological products ranging from the creative and fictional to the ethnographic. Kimberle López's understanding of the latter as 'inherently parasitic [...] feed[ing] off the Other, depending on the cultural "inferiority" of this Other and reinforcing its exoticism through writing' could also apply to literary works in Europe. Fin-de-siècle European bourgeois cosmopolitan experiences, as portrayed in many a European novel of the period, emerge through the overlapping processes of European colonialism, global flows of capital, and the power dynamics they reproduce. The European bourgeois subject, who frequently traveled to and wrote on Brazil, is thus the 
condensation of European colonial power over not only its own continental territory but the web of global markets and othered bodies that constitute the signifying field of Empire.

Edward Said's analysis in Orientalism of Gustav Flaubert's novelistic deployment of otherness adds yet another layer of Western agency to the act of writing, in this case, the Orient: 'Like every other Orientalism, then, Flaubert's is revivalist: he must bring the Orient to life, he must deliver it to himself and to his readers' (185). Flaubert's consumption of non-European otherness - its usage in the novelistic medium - always allows a space for the consolidation of the European bourgeois ego (both individual and collective). The writer/consumer is thus also a producer - the facilitator of broader consumption through the piece of literature that is mechanically reproduced, commoditized, and circulated.

Consumption therefore implies a multilayered performance of bourgeois identity in the world of globalized capital. The reproduction and consolidation of the Western/European subject (in the late nineteenth and early twentieth century, in the case of Flaubert and his contemporaries to whom the anthropophagists were exposed) is rendered by more than the mere existence of identitarian opposition (Westernness versus otherness). It is also reproduced, as Said suggests, through the repeated and palimpsestic writing and imagining of otherness. The symbolic existence of Western imperial power, the plane of meaning upon which it is couched and experienced, is thus reproduced through the mechanisms of consumption - the repeated placement of signifiers of sameness and otherness (itself a form of consumption) - into consumable artifacts such as literature. In other words, the relationship between writing otherness and reading it, enabled by Western print industries, is crucial to the reproduction of Empire in the nineteenth and early twentieth century.

It was as a performance of consumption through which many European travelers, mainly French and English, took in Brazil during their visits. Like a Persian rug or orientalist statue, Brazilian space was to be consumed, to become a part of European bourgeois culture and knowledge, and thus signified accordingly. It is no wonder that so many travelers were, themselves, producers of meaning - artists, philosophers, diplomats, or simply writers of memoirs or travel accounts that would later be published. An important aspect of European bourgeois life is thus the creation or reproduction of knowledge, more precisely, certain imperial forms of it. As Walter Mignolo puts it, regarding the relationship between racism and epistemology, or the international division of knowledge production, 'the First World has knowledge; the Third World has culture' (Darker Side 118). (Post)colonial geographies are thus seen as semantically blank spaces rendered as loci 
of otherness through centuries of imperial power; always objects to be signified and represented, seldom agents doing the signifying.

French painter François-Auguste Biard (1799-1882), as an example of the many European travelers to narrate/render Brazil in the nineteenth century, was known as an artistically vocal abolitionist some of whose most canonical works depicted the horrors of the African slave trade. Nevertheless, other commentary of his pertaining to Africans and Afro-descendants 'almost always associated,' writes Ana Lucia Araujo, 'slaves with degeneracy, explicit sexuality, and consequent disease' (79). Araujo mentions in her book on Biard's two-year stay in Brazil and the works he produced there that 'he was not interested in the urban scene. He managed to organize an excursion to the forests of the province of Espírito Santo. However, since this experience did not fulfill his ambitious expectations to meet and paint Brazilian Natives, he embarked on a long expedition in the Amazonia' (xv). Biard's true search, in other words, was for a phantasmatic 'pure' otherness, understood as precolonial otherness - that which remains untouched by European civilization, despite already being an object of European knowledge. Biard's works on Amazon life thus add another layer of meaning to the existing body of knowledge on the Amerindian other. The artistic product serves as a helpful metaphor of European imperial consumption. Biard visually consumes the other and places its image on the canvas so that it may be consumed in the European metropolis, specifically its bourgeois spaces - a site of global interpretation and inscription.

Upon returning to Paris after more than ten years, Adèle Toussaint-Samson, another French traveler in nineteenth-century Brazil, expressed how she felt 'saudade (homesick), as the Brazilians say, for South America' (101). She is, of course, referring to a particular version of Brazil and South America as it is contained within imperial knowledge. Her nostalgic longing for Brazil is directed more specifically toward 'those immense horizons, which elevate the soul and the thoughts, my sea-baths in the moonlight on the phosphorescent beach, my horseback rides through the mountains, that beautiful bay on which the windows of my house looked out' (100). Brazilian space, seemingly imbued with nature's beauty and vastness, offers the opposite of 'our Parisian life, so narrow, so luxuriant in appearance, and so scrimped in its reality' (100). The consumption of Brazil's ample natural space implies an enjoyment of it that is restricted to domestic and foreign elites: 'I recalled to myself those long miles travelled over in Brazil, where nature alone takes care to bear the costs, where the unhappy one could pluck at his leisure a banana, an orange, and the palmetto without being disturbed by whomsoever it might be' (Toussaint-Samson 100). 
This exotic terrain and its exotic signifiers are, of course, a surplus, never a substitute, to the already-consumed metropolitan city life that is nonetheless the imperial subjective place from which the consumption of the other takes place: 'One thing consoled me upon my return for the littleness of material existence. "Here I am, returned to the country of thought and progress," said I' (Toussaint-Samson 101). The metropolis is never decentered as the spatial-cultural-economic core of bourgeois cosmopolitan identity and imperial signification. To displace this core would foreclose the signification and consumption of the peripheral postcolonial nation as the exotic commodity.

\section{Rearranging Consumption}

Antropofagia emerged in the wake of over three centuries of Portuguese colonialism, and another of continued colonial power in which the postcolony remains entrapped in transnational industrial capital and an imperial web of intercultural meanings in which other European powers partook, as in the examples of Biard and Toussaint-Samson. Evando Nascimento traces the two modes of appropriating European cultural forms hypothetically confronted by Oswald de Andrade. The first option would have been 'de maneira servil, ou seja, sem reinvenção do legado, uma mera repetição sem diferença [...] a irreflexão quanto da impossibilidade de pensar ou realizar algo diferente do que o europeu já tenha feito' ['in a servile fashion, that is, without reinvention of the legacy, a mere repetition without difference (...) the failure to consider the impossibility of thinking or achieving something different from that which the European had already done'] (344). This would seem to be the path taken by many artists and intellectuals in Tropical Belle Époque Rio de Janeiro; that is, the use of cultural and aesthetic practices with little reflection on the transatlantic or global/colonial power dynamics to be found at their core. The second option - that chosen by Oswald de Andrade and the Antropofagistas - was that which 'visaria, no gesto mesmo de tomar a cultura europeia para enxertá-la em território nacional, digeri-la, fazendo uma seleção, e impondo um cruzamento com elementos autóctones' ['would aim, through the very gesture of taking European culture to insert it into the national territory, to digest it, selecting pieces of it, and crossing it with autochthonous elements'] (345).

The movement thus takes up consumption not merely as the reappropriation of a colonial trope of primitive otherness - now it is directed against European cultural forms and global flows of capital. After all, 'the cannibal text had originated in Europe; since Montaigne and Staden, cannibal tales have been a prime source for the Western imagination' (Jackson 92-93). 
The primitive construction of the Amerindian within European colonial discourse - idealized and admired for his ties to nature by renowned European cultural figures such as Montaigne and Chateaubriand - is reformulated by the Antropofagia movement into the horrific European image of the Amerindian, the cannibal that threatens European presence. The image of the cannibal, itself a colonial stereotype/fantasy, is explored by the Antropofagistas fundamentally as an ontological site of transgression vis-à-vis imperialism, cultural and economic. Jackson observes that:

Brazilian avant-garde artists reinvent primitive society from a New World perspective. They explore cannibalism as a metaphor, broadened to include other ritual practices, in a theory of national autonomy and development opposed to Europe [...] substituting periphery for center, they propose indigenous society as a mythical locus for renewing Western social philosophy, ethnography, and art. (90-91)

The cannibal trope is, at its core, deployed to decenter the ontological site of consumption, theorizing how the postcolony situates itself, culturally, within contemporary global power and capital. This implies an opposition not only to Europe and the global North's consumption of the postcolony, but also to the Eurocentric forms of culture and social organization in the postcolony's main cities. Jackson thus posits Antropofagia as 'an avenue to postcolonial intellectual autonomy' (91). He goes on to assert that the movement 'exploit[s] primitivism conceptually by constructing a wild cultural and philosophical theory, in which primitivism reconstructs national identity' (91).

Jackson is one of many critics who have approached Antropofagia in terms of a cultural project of reformulating national identity. We can, however, read Antropofagia (through the anthropophagic works of Mário and Oswald de Andrade) differently - as a project tied to decolonial writing against Empire and as a project that stops just short of national identity, by narrating a place from which national identity and a reformulation of the nation-sign can emerge. To this end, both writers labor toward a model for the postcolony to also consume, that is, to ingest, meaning - be it cultural, economic, or ethnographic - and reformulate it, thus signifying it anew, enunciating knowledge from the site once consumed. In other words, Mario and Oswald de Andrade's conception of the anthropophagic being is more of a scene of writing than a mapping of national identity. Oswald de Andrade (like many other contributors to Antropofagia), alludes often to the search and/or construction of 'o Brasil-brasileiro' ['the Brazilian Brazil']. While he arguably establishes this national reformulation as the ultimate goal, one can also read his work as focusing more on the process of reaching it - 
through the metaphor of consumption - than on establishing the cultural parameters and characteristics of this revised nation-sign.

Focusing on consumption, Antropofagia is concerned with more than 'etiologies: the origins of a genuine national culture' (Madureira 22). As Luís Madureira points out in his exploration of the movement, 'these original sources can be retrieved only in simulacral form, only as protean, unreliable traces from which the authenticity of the original Brazilians (a profoundly inauthentic expression) must be purged of the distortions imposed by Renaissance [Europe]' (22). The anthropophagist interest in consumption and its significational ramifications, though, suggests that some members of the movement were invested less in articulating a national culture than in theorizing an ontological place from which such a culture or cultures may emerge. Madureira thus recognizes 'the possibility that antropofagia anticipates what Paulo Freire has called a "postmodern" alternative to the west's narrative of emancipation: the repudiation of a "modernist" politics' (23).

At the core of my exploration of allegory in Mário and Oswald de Andrade's work is the argument that in laboring toward a new ontological location from which to produce culture, Antropofagia was not a search for an authentic pre-European Brazilianness. Rather, Antropofagia's deployment of the primitive is a strategic recycling of Western imperial signifiers, a form of 'writing back to a variety of metropolitan pundits,' as Albert Braz frames Mário de Andrade's dialogue with primitivism (17). In other words, anthropophagic primitiveness does not evoke what came before colonialism, itself an intangible, but instead builds over the products of Western hegemony as it continues to reproduce itself. Oswaldo Costa, another contributor to the modernist movement, perhaps captures this mission most succinctly in the first issue of Revista de Antropofagia: 'O Brasil occidentalisado é, portanto, um caso de pseudomorphose historica [...]. Só a antropophagia consegue resolve-lo. Como? Comendo-o' ['Westernized Brazil is, therefore, a case of historical pseudo-morphosis (...). Only anthropophagy can resolve it. How? By eating it'] (6). The project of Antropofagia regarding History, the narrative of Western power, is thus to consume it, from its imposed margins - the otherness which Empire engendered - in order to move beyond said otherness, becoming subject rather than object of meaning and cultural production. This means, in the poetic words of Oswald de Andrade, to cease being the place 'donde a nunca exportação da poesia' ['of no poetic export'] (Pau Brasil 101).

The objective is not necessarily to wipe out or erase in order to begin anew, as tends to be the case with modernist projects, and as many literary and cultural critics have read Antropofagia, but to set in motion a reconfiguration of the Western signifying chain through which notions of Brazilianness can 
be de-Occidentalized, or decolonized. The reconfiguration would emerge via a thinking through of how to consume that signifying chain - from within it, not so much from outside of it, or before it. This therefore counters the 'modernist assumption of the death of the past as the basis of historical understanding' (Spiegel 149). The very choice of the cannibal as the image of the movement and its fundamental political project suggests the impossibility of killing imperial narrativization and what it has left throughout several centuries, while indicating an anthropophagic cognizance of that impossibility. The digestion of the imperial entity, to be sure, always implies a continuity, for better or worse, rather than an effective elimination.

The voice behind the colonial image of the Tupi cannibal other has been silenced out of History, and the only access to pre-European life on the piece of land called 'Brazil' is through European historicization. A decolonial historical understanding does not, in the case of Antropofagia, mean a precolonial historical understanding. Jackson almost suggests as much when he recognizes that much of the anthropophagists' 'work also derives from unsung antecedents in their national historiography. These include works on ethnography, Tupi-Portuguese grammars, early religious drama, sermons, travel accounts, writing about the Amazon, and epic poems on Indianist themes' (94). In analyzing Antropofagia's cultural discourse, it is important to thoroughly unpack the movement's deployment of primitivism through the use of colonial knowledge. The sources which Jackson mentions are all products of a Western logocentric will to knowledge that utilizes colonial taxonomies of human life pertaining to skin color, language, worship, and spatial praxis.

Antropofagia was not so much a search for a precolonial voice within these colonially produced texts, but rather a laboring toward a decolonial voice that can emerge from rereading such texts - consuming the otherness that was already colonially consumed in the production of Western knowledge. Antonio Luciano Tosta crucially underscores the 'revolutionary aspect' of Oswald de Andrade's project and reads it as more than a return to 'indigenous roots, but also [a project] to follow - and supersede - the Europeans' (220). The movement calls for a decolonial act in its enunciatory present from which consuming, through reinterpreting and deconstructing the Western field of meaning, will foment postcolonial knowledge. In aiming to conceive of a decolonial site of enunciation from the signifiers of the imperial narrative of the West, Antropofagia essentially initiates this reconfiguration. Articulating a modernist postcolonial scene of writing would be the fundamental delinking and reordering of the imperial narrative and its signifiers from which the West can be reread - that is consumed and rearticulated. As a modernist discourse, it promises newness, but without 
explicitly delineating the cultural parameters of the future - what the nation-sign is to be. Herein lie the postmodernist traits of Antropofagia: the opening of a possibility for resignification without containing it within a specified model of national identity. This understanding goes against the grain of more established readings of Oswald de Andrade's work, and of the anthropophagic movement as a whole. Haroldo de Campus, for instance, considers Oswald de Andrade's Pau Brasil to be a poetic project searching for Brazilian collective roots (7-10).

Evidence of this non-specific decolonial scene of writing can also be found in the reluctance - which varied among different participants in the movement - to situate national resignification in one particular subject position that has emerged from within the imperial field of meaning. Oswald de Andrade's Antropofagia does not take a colonial trope of otherness into a national allegory that subsumes the multiple subject positions emerging from centuries of imperial power and narrativization. In other words, the 'Brazilian Brazil' is not a nation-sign to be articulated from one privileged site of identity over others. In many ways, Antropofagia gestures toward a narrative about an unspecific yet historically formed scene of national writing. It is, however, one that acquires a not-fully-problematized multiculturalist narrative, especially in the works of Oswald de Andrade. For instance, Heloísa Toller Gomes underscores Oswald de Andrade's avoidance of Afro-Brazilian topics, an apparent shift from his 'Manifesto da Poesia Pau-Brasil' ['Manifesto of Brazilwood Poetry'] of 1925 to his 'Manifesto Antropófago' of 1928: 'na proposta e na elaboração da antropofagia - ou seja, no Manifesto de 1928 e nas duas ediçóes de 1928 da Revista de Antropofagia - percebe-se uma retração no tratamento da temática afro-brasileira' [in the proposal as in the elaboration of antropophagy - that is, in the 1928 Manifesto and in the two 1928 numbers of Revista da Antropofagia - one can perceive a withdrawal in his treatment of Afro-Brazilian themes'] (406).

This would suggest that within this anthropophagic multiculturalism, at least in Oswald de Andrade's conception of it, blackness occupies a liminal if not nonexistent role in the construction of nationhood. Toller Gomes notes that Oswald de Andrade would later address the place of blackness in this Brazilian-Brazil in an essay written in the early 1940 s, but even then, focusing mainly on Afro-Brazilian cultural forms, much is left unexplored (i.e. the impact of slavery and urban renewal on such forms). In his collection of poems on the colonization of Brazil - 'Poemas da Colonização' - in Brazilwood Poetry (analyzed below), Oswald de Andrade provides a nuanced exploration of these historical phenomena and the construction of black otherness in the imperial field of meaning. One can perhaps then read his more focused turn toward Amerindian imagery not necessarily as a foreclosure of blackness 
from the enunciation of a soon-to-be resignified Brazil, but as an initiation of the articulation of a decolonial site of historical consumption beginning with the emergence of Brazil as a sign within Empire.

Here we can perhaps see a desire on the part of Oswald de Andrade to establish a starting point for Antropofagia's narrative of consumption. What this vision of colonial discourse, and its historical trajectory, subsequently leaves out is an acknowledgement of the transcontinental contours of the colonial discursive formation of the Amerindian other. Its imperial articulation as a conglomeration of signifiers pertaining to race, sexuality, and religion cannot be neatly separated from other imperial constructions of difference that circulated throughout Europe and the early modern colonial world. Nonetheless, this possible temporal point of departure does not seek a starting point located outside of or temporally prior to Tupi insertion into Empire.

Toller Gomes goes on to argue that the cultural and philosophical treatment of Afro-Brazilianness within the movement ultimately led to the rift between Oswald and Mário de Andrade. Where the latter called for a greater centrality of blackness within the national imaginary while also offering a critique of imperial racial discourses underpinning Afro-Brazilian experiences, the former seemed to privilege an Amerindian centrality. Kimberle López reminds us that prior to the publication of Macunaima, Mário de Andrade publicly lamented 'that his forthcoming work w[ould] be associated with the Anthropophagist movement' (28), but that his novel is nonetheless 'widely recognized as a vital practical enactment of what Oswald de Andrade put forth in theoretical terms in his manifesto' (28). While it may be difficult to separate Macunaima from Antropofagia in light of Mário de Andrade's theoretical divergences from Oswald, both nevertheless offer important, competing, and overlapping blueprints for rethinking the postcolony's relationship to Empire. Both ultimately propose, as Tosta argues, 're-readings of power relations that give emphasis to the agency implicated in cultural change' (218).

\section{Allegory against Totality: The Case of Oswald de Andrade}

For the Antropofagia movement, an engaged cultural critique of postcoloniality is closely tied to a similar critique of local and global History. Moreover, these fragments, such as signs of race, are central to the articulation of postcoloniality in the Anthropophagic œuvre, since they convey the trans-temporal nature of colonial discourse vis-à-vis Latin American nationhood. At the core of Oswald de Andrade's Pau Brasil, the praxis of reusing and recycling imperial signs, critically consuming them to delink 
their coloniality, leads to an allegorical writing that involves doubling or reduplicating extratextual material [...] the allegorical sign refers always to a previous or anterior sign' (Slemon 158), the ultimate goal being

to proceed beyond a 'determinist view of history' by revising, reappropriating, or reinterrupting history as a concept, and in doing so to articulate new 'codes of recognition' within which those acts of resistance, those unrealised intentions, and those re-orderings of consciousness that 'history' has rendered silent or invisible can be recognised as shaping forces in a culture's tradition. (Slemon 159)

Allegory therefore functions in both Pau Brasil and Macunaima in the way Walter Benjamin would famously theorize with regard to German Trauerspiels in his The Origin of German Tragic Drama (published the same year as Mário de Andrade's novel); that is, as an 'art of the fragment' corresponding 'to a perception of the world in ruins' (Tambling 110). As Rosenberg observes, 'the ruins of symbolic unity are everywhere' (88) in Macunaima. The symbolic unity would, therefore, pertain to the imperial sign under which the postcolony has been narrativized. Both Benjamin and Oswald de Andrade articulate an allegorical model that constantly contests the notions of completeness, through which imperial power has been expressed. Much like Benjamin's reading of Trauerspiels, Oswald de Andrade favors historical ruins, approaching imperial signs (like those of race) as such, in opposition to a unified chain of symbols like those comprising many imperial myths.

In his in-depth exploration of Macunaima's allegoric core, Fernando Rosenberg points out the novel's 'allegoric fabric that also eschews symbolic closure' (84). This permanence of open-endedness and unfixity also permeates the poetry and manifestos of Oswald de Andrade, compromising any possibility of a coherent signifying chain in terms of both the plot and the postcolony. What interests me is not merely how symbolic closure is forgone and renounced, but how such an allegorical function against the symbol contributes to the emergence of a decolonial scene of writing.

Allegory for both Benjamin and Antropofagia can radically unsettle this peaceful unity and consistency of the symbol, its supposedly 'essential, unchanging existence' (Tambling 116). Benjamin notably argues that:

Whereas in the symbol destruction is idealized and the transfigured face of nature is fleetingly revealed in the light of redemption, in allegory the observer is confronted with the facies hippocratica of history as a petrified primordial landscape. Everything about history that from the very beginning has been untimely, sorrowful, unsuccessful, is expressed in a face - or rather in a death's head. (Origin 166) 
It should come as no surprise that Benjamin theorizes new significational possibilities against the fixed, if not eerily articulated, terms of imperial narrativization - 'death's head' and 'history as a petrified primordial landscape.' More than unsettling historical narrativization, allegory can potentially, and frighteningly, undo present meanings and, in the process, compromise certain individual subjectivities that exist therein, as the horrors of historical signification (such as racial violence) are revealed. Jeremy Tambling is thus correct in suggesting that allegory potentially 'disrupts the rule of ideology' (116); particularly by incorporating the narrative subtext/unconscious where memory of such traumas persist.

For this reason, in developing a sustained theoretical exploration of allegory, Benjamin brings forth a new notion of the Romantic symbol in which it 'relinquishes its oppositional stance to allegory and becomes merely its false mirror-image, an ignis fatuus' (Cowan 112). Bainard Cowan notably points out that Benjamin's distinction between allegory and symbol dovetails with his theses on history. The imperial sign of otherness $v i s$-à-vis allegory produces an image of unity 'that is free from all real conflicts, to be fixated by the "beauty" of this image - actually a kind of Medusa - and fails to recognize one's own face, the face of history, with all its marks of suffering and incompleteness' (112). Similarly, Antropofagia begs us to read History through these precise marks. To read History anthropophagically, or allegorically, is to concentrate on the fragments that are fragilely glued together by a significational gaze that is itself fragmentary but constructed through the violence of domination over lands, bodies, and meaning. Through such a reading, as we shall see in the case of Oswald de Andrade's work, 'the false appearance ceases to exist. For the eidos [idea] disappears, the simile ceases to exist, and the cosmos it contained shrivels up. The dry rebuses which remain conceal an insight which is still available to the confused investigator' (Benjamin, Origin 176). History, therefore, in the anthropophagic context, can be read now as a double: a sort of dialectic between the Western desire for totality and the false image of that totality.

This is the very premise behind the cannibal allegory in which subaltern subjectivities and their own significational gazes can disrupt Western narrativization by consuming Western/imperial cultural signs and historicity, digesting them, and formulating new historical meaning. The fundamental allegory operating is therefore the enunciation of a new point of historical articulation and knowledge production erected from the ruins left by Empire. As an allegory, it is also a product of fragments. From the ruins of History, Antropofagia, at least for Mário and Oswald de Andrade, gestures toward a new postcolonial/decolonial significational gaze that 
reassesses Western narrativization and the nation's place within that field of meaning.

In the movement's manifesto, Oswald de Andrade lays out the edification of this gaze through a pastiche of fragments of Western imperialism and colonial history of the Americas. The manifesto reads like a long series of short acute utterances that intertwine signifiers of imperial discovery, colonial society, and global capitalism. Aquino and Lotti underscore the poetic nature of Oswald de Andrade's manifestos, including his earlier 'Manifesto da Poesia Pau-Brasil':

O poeta prossegue estruturando seu manifesto por meio de frases nominais, próprio de um poeta [...]. Trata-se do uso das figuras de estilo que são próprias da linguagem poética, mas são aqui utilizadas estrategicamente como elementos persuasivos do discurso. A escolha lexical remete a imagens [...] ritmo e sonoridade que afloram, por exemplo, do paralelismo e da estrutura em versos. (132)

[The poet structures his manifesto through nominal sentences, in the vein of a poet (...). The manifesto deploys stylistic devices germane to poetic language, but which are strategically used here as persuasive discourse. The lexical choices invoke images (...) rhythm, and sonority that emerge through the parallelism and stanza-like structure.]

These statements packaged in short paragraphs, or textual blocks, themselves forming fragments, are framed as a voyage through History, mutually substituting time and space, as in classical forms of allegory like that of Dante. The radical aspect of the cannibal allegory resides in the manifesto's enunciatory voice, in which the implied narrator takes up the project of consuming the pieces of imperial narrativization:

Filiação. O contato com o Brasil Caraíba. Ori Villegaignon print terre. Montaigne. O homem natural. Rousseau. Da Revolução Francesa ao Romantismo, à Revolução Bolchevista, à Revolução Surrealista e ao bárbaro tecnizado de Keyserling. Caminhamos [...]. (3)

[Filiation. Contact with Carib Brazil. Ori Villegaignon print terre. Montaigne. Natural man. Rousseau. From the French Revolution to Romanticism, to the Bolshevik Revolution, to the Surrealist revolution and the technological barbarian of Keyserling. Let's continue on (...).]

The paragraph/stanza notably begins with an allusion to the political, economic, and ontological plight of postcoloniality. From there, this subordination is further articulated in terms of the ontological sites from 
which colonial space and time were signified. Villegaignon, Montaigne, and Rousseau, of course, all traveled to and/or wrote about the colonial New World. What follows are political and cultural shifts in Europe, in the geographically located hegemonic site of New World signification that also affected how postcolonial elites shaped nationhood. As Beth Joan Vinkler extrapolates from the manifesto, the work 'advocates the overthrow of the existing social power structure - for Oswald the "modus vivendi capitalista" - in favor of a radically different, and decidedly more liberated social order' (105).

The shift in social order is couched against the formation of contemporary power and its field of meaning, of which the manifesto offers a partial yet complex genealogy. The paragraph's first word informs the relationship between the manifesto's allegoric enunciatory voice and History. It also underscores the movement's modernist project, or at least Oswald de Andrade's vision of it, encapsulating Bhabha's perceived implications of alternate modernities: 'each repetition of the sign of modernity is different, specific to its historical and cultural conditions of enunciation' (247). In this regard, the manifesto sets up a transition from Western modernity and its inscribers-turned-signs (Montaigne, Rousseau, etc.) to a new ontological site that can efface the former - what Enrique Dussel refers to as History's and modernity's 'archetypal foundational I' (8).

The allegorical voice of the manifesto - allegorical because it arises from the reduplication of politically spawned signs - explicitly demands a break from this 'I' and its narrativization: 'Contra as histórias do homem que começam no Cabo Finisterra. O mundo não datado. Não rubricado. Sem Napoleão. Sem César' ['Against the histories of man that begin at Cape Finisterre. The undated world. Non-rubricated. Without Napolean. Without Caesar']. The short-lived movement's mission is, therefore, more radical than a reformulation of Western meaning (as expressed through its cannibal metaphor), implying less an erasure of its signs than their critical disentanglement from the ontological sites from which they were written. This would be a splitting of the sign from its imperial scene of writing.

The enunciation of this scene of writing, produced allegorically, becomes the decolonial mechanism through which postcolonial experiences can be inscribed. The allegorical voice is always tied to experience; or rather, as Cowan extrapolates from Benjamin, 'allegory is experience par excellence: it discloses the truth of the world far more than the fleeting glimpses of wholeness attained in the Romantic symbol' (112). For Oswald, allegory is not only the means by which postcoloniality is conveyed, it is integral to the mission of decoloniality - to take a sign and delink it from the order of power from which it emerged and which it also serves. Is this not the 
point of the movement's cannibal trope based on the Tupi's consumption of Bishop Sardinha's body, delinking flesh from bone, Sardinha as scene of writing from the imperial signs he produced?

In a letter to Raimundo Moraes included in the critical edition of Macunaima, Mário de Andrade gives us further clues as to how the anthropophagic gaze of postcolonial experience and signification manifests itself; offering his own consumption as writer as a possible blueprint. He thus responds to accusations of plagiarism regarding Macunaima:

Copiei, sim, meu querido defensor. O que me espanta e acho sublime de bondade é os maldizentes se esquecerem de tudo quanto sabem, restringindo a minha cópia a Koch-Grünberg, quando copiei todos. E até o sr., na cena Boiúna. Confesso que copiei às vezes textualmente. Quer saber mesmo? Não só copiei os etnógrafos e os textos ameríndios, mas ainda, na Carta pra Icamiabas, pus frases inteiras de Rui Barbosa, de Mário Barreto, dos cronistas portugueses coloniais, devastei a tão preciosa quão solene língua dos colaboradores da Revista da Língua Portuguesa [...]. Enfim, sou obrigado a confessar uma vez por todas: eu copiei o Brasil, ao menos aquela parte em que me interessava satirizar o Brasil por meio dele mesmo. Mas nem a ideia de satirizar é minha pois já vem desde Gregório de Matos, puxa vida! Só me resta pois o acaso dos Cabrais, que por terem em provável acaso descoberto em provável primeiro lugar o Brasil, o Brasil pertence a Portugal. Meu nome está na capa de Macunaíma, e ninguém o poderá tirar. (424)

[I copied my beloved defender, yes. What surprises me, and that I find sublimely kind is the critics forgetting everything they know, restricting my plagiarism to Koch-Grünberg, when I copied everyone. Even the man in the Boiúna scene. I confess that I copied sometimes textually. Do you really want to know? I not only copied the ethnographers and Amerindian texts, but also, in the Letter to Icamiabas, I placed whole sentences from Rui Barbosa, Mário Barreto, Portuguese colonial chroniclers; I devastated the precious and solemn language of the collaborators of the Journal of Portuguese Language [...]. Finally, I am forced to confess once and for all: I copied Brazil, at least that part I was interested in, for the sake of satirizing Brazil by way of itself. But not even the idea of satirizing is mine because it has been around since Gregório de Matos, darn it! All I am left with is the chance of the Cabrals, whose discovery of Brazil supposedly by chance and supposedly first, meant that Brazil belongs to Portugal. My name is on the cover of Macunaima, and no one can remove it.] 
Mário de Andrade's novelistic project therefore embodies the creative proposal outlined by Oswald in Antropofagia's manifesto - a new narrative gaze that incorporates, but does not speak for, previously silenced epistemes while resignifying nation. His most telling statement in the letter above is 'I copied Brazil' - an example of consumption as reading/interpreting and rewriting. In this regard, the Brazil copied is starkly different from the sign hitherto articulated. The question of copying has been a contentious topic within the scholarship on Antropofagia and Brazilian modernism. Benedito Nunes, positing figures such as Koch-Grünberg as European cannibals (in response to Heitor Martins's essay 'European Cannibals and Brazilian Anthropophagists'), argues that simply equating Antropofagia's appropriation of European ethnographers and cultural producers (including Cubists and Dadaists) with the facile act of copying denies 'até a total liquidação de sua originalidade, o conteúdo específico das formulações antropofagísticas de Oswald de Andrade' ['all originality to Oswald de Andrade's specific anthropophagic formulations'] (319). In this regard, Nunes continues, 'discordamos da interpretação segundo a qual a antropofagia de 1922 se reduz às matrizes do canibalismo europeu' ['we disagree with the interpretation reducing the Antropofagia of 1922 to the matrices of European cannibalism'] (319; emphasis original).

Fernando Rosenberg interestingly theorizes the method of copying through an analogy of emptying the sign, exemplified by Macunaíma's lack of character, thus always already questioning his agency. Moreover, as Rosenberg notes, this speaks to 'the compositional process of the novel, which by borrowing profusely from various sources, as Brazilian folk singers do, radically revised the hierarchy of original (full) and copy (empty)' (87). Rosenberg quickly reminds us, though, that 'this empty signifier supports a discourse of conciliation, incorporation that would have enormous weight in Latin American understandings of its modernity' (87).

The act of copying also places the superimposed fragments in dialogue with one another. This speaks to one of the specificities of the allegorical function in Oswald's manifesto and Mário's novel - History is not unity but contradiction - even at the level of the narrative voice in which opposing epistemologies compose the novel's signifying chain. Furthermore, rather than proposing a synthesis, Mário de Andrade's meshing in Macunaima and Oswald de Andrade's throughout his poetry, call for a constant renegotiation of nation - what Tom Nairn refers to as the 'modern Janus' (see Faces of Nationalism). The unfixity of the sign, along with its implied perpetual postponement of meaning is, according to Bhabha, what makes the sign culturally productive. The 'sense that allegorical modes illustrate a resistance 
to communication and meaning' (Tambling 154-55) opens the spectrum of possibilities from which meaning can emerge, since meaning is constantly challenged and in flux.

As noted earlier, the discourse of Antropofagia destabilizes not only the sign of the nation within History but, perhaps more crucially, the historicizing gaze which Dussel refers to as the "archetypal foundational "I"' (8). In what can be considered a deconstructionist stance (avant la lettre), the anthropophagists assert the lack within the enunciatory subject of History, as a linguistic being that can only reside in the field of meaning it reproduces and through which it emerged. This is a gulf not so much between word and object, but between what exists in and through writing and what remains outside of meaning - the Lacanian distinction between the symbolic order and the Real. The Western right to signify or even Westernness itself, in other words, only exists in Western narrativization as the symbolic, while in the Real, there is no corresponding Western racial and cultural superiority; there is no West, for that matter. The use of allegory implies a consciousness that, in the words of Paul de Man, 'signifies precisely the non-being of what it represents' (35). The ideological construction of reality is, therefore, predicated on allegory, since ideology - in its representation of the relationship between real (physical, positive) entities - exists firstly at the level of the signifier. By perpetually destabilizing the site of articulation as a sign, the postcolony is also unfixed, freed from any attempted seizing of reality as a discursive totality.

\section{Pau Brasil: Consuming Empire from the Periphery}

Brazilian cultural critics and scholars have long examined the impact of Oswald de Andrade and Antropofagia on the evolution of linguistic practice in twentieth-century Brazil. Paulo Prado and João Ribeiro, contemporaries of the anthropophagists, discussed the celebration of colloquial Portuguese in the prose and poetry of the latter. Haroldo de Campos reads the structure of linguistic production in their work in a different light, underscoring instead the brevity, fragmentation, and arguable incompleteness in the prose and poetry of Oswald de Andrade, referring to it as 'uma estética redutora' ['a reductive aesthetics'] (16). This brevity as poetic form, one can argue, corresponds to an avoidance of the phantasmatic totality of the sign while charting genealogies of Empire, thus ensuring that the larger signs of Empire and History are not conveyed as narrative totalities, but as disjoined series of apertures and moments.

Much like Mário de Andrade's novel, Oswald de Andrade's poetic discourse also embodies temporally and spatially disjoined voices and meaning. As in 
his manifestos, Oswald deploys images that are not merely erratic, but that have also contributed to the narrativization of Brazil, especially colonial historicization. His Pau Brasil collection can be read as a poetic rewrite of Brazilian Western historicization, of which the 'Manifesto Antropófago' reads like a synthesis. More crucially though, in the desire to revisit and to challenge, the imagistic force of the poetry recreates more than historicized signs, but also the temporally disjoined mise-en-scène in which national colonial meaning emerges in the past.

Jorge Schwartz reads the development of Pau Brasil as structured by the trope of travel: 'encontramos nele uma espécie de percurso histórico que se inicia no descobrimento, passa pelo Brasil colonial, pelo barroco de Minas Gerais, pela província cosmopolita e chega até o Carnaval' ['we find a type of historical journey beginning with the discovery, passing through colonial Brazil, the baroque of Minas Gerais, the cosmopolitan province, all the way to Carnaval'] (57). As we shall consider through passages from Pau Brasil, each poem presents, briefly and in a disfigured bricolage, delinked moments of Empire. By minimalistically presenting imperial narrativization with disconnected temporalities, Oswald de Andrade presents an alternative signifying chain regarding the capitalist/imperial periphery, from this very location. The postcolony/location from which the poem is written is thus the product of the very imperial signifying chain for which Oswald creates an alternative disjoined version. The disconcerted alternative is not presented as a fixed alternative. The openings in the signifying chain, emerging through the aesthetic delinking, open possibilities for further anti-imperial readings through which eventual radical relinkings may take place. This anti-imperial dialectic of reading and relinking must also comprehend the complex relationship between enunciator and disjoined signifying chain operating in the collection. If the enunciator is the historical product of the phantasmatic totalized signifying chain of imperial History, then the apertures presented in the delinked alternative must imply the eventual erasure of the enunciator. Another enunciator - born through, and producing, the relinking - is then allowed to emerge and supplant Oswald de Andrade's poetic voice.

The first chapter of the collection, titled 'História do Brasil,' is composed of plagiarized, yet poeticized, fragments of notable travel and missionary writings on Brazil. Schwartz places this act of plagiarism within the political and aesthetic goals of Modernismo: 'o poeta se apropria de documentos históricos de inícios do séc. XVI e XVII, faz um recorte poético e os reconstrói dentro da nova dimensão moderna do poema de vanguarda' ['the poet appropriates historical documents of the early sixteenth and seventeen centuries, poetically cuts and reconstructs them within the modernist 
dimensions of the vanguard'] (57). The collection begins with Pero Vaz de Caminha's letter of 'discovery' to the Portuguese crown:

\author{
os selvagens \\ Mostraram-lhes uma gallinha \\ Quasi haviam medo della \\ E não queriam pôr a mão \\ E depois a tomaram como espantados. (107)
}

\title{
[the savages
}

They were shown a chicken

They were nearly frightened by it

And they refused to touch it

They then took it as if startled.]

Other notable chroniclers whose writing informs this chapter of the collection include Pero de Magalhães Gândavo, Claude d'Abbeville, Friar Vicente do Salvador, Fernão Dias Paes, and Friar Manoel Calado. More than repeating these voices, Oswald de Andrade repeats the scenes in which writing takes place. He does so through the overt technique of titling, in which the original text he copies is broken up into pieces. Therefore, what stands out is the moment of historical inscription in addition to the agent of its writing. The first of these is 'a descoberta' ['the discovery'], followed by 'os selvagens' above. The latter is to be read as the moment of encounter in which, through colonial signification, time is rendered in terms of the othered body.

Each section of 'História do Brasil' bears the name of a chronicler or traveler of the early colonial period, presenting fragmented and disrupted versions of their respective historicizing acts, thus de-totalizing them and infusing them with openings for reinterpretation. These are all texts that have given imperial meaning to time, space, bodies, and objects and through these have created the historical sign, Brazil, and guided its placement in Empire's field of meaning.

While 'História do Brasil' represents a sort of decolonial editing, the subsequent chapters are comprised mainly of a more direct poetic voice. The next chapter, almost predictably titled 'Poemas da Colonização' ['Poems of Colonization'], begins with the poem 'A transação' ['The transaction'], which charts the colonial transition from sugar-based economy to a mining economy to one dominated by coffee plantations, all undergirded by slave labor:

\author{
a transação \\ O fazendeiro criara filhos \\ Escravos escravas
}


Nos terreiros de pitangas e jabuticabas

Mas um dia trocou

$[\ldots]$

Por terras imaginárias

Onde nasceria a lavoura verde do café. (123)

[the transaction

The plantation owner raised children

Male slaves female slaves

On the terraces of Surinam cherries and jabuticabas

But one day exchanged

(...)

for imaginary lands

where green farms of coffee would be born.]

The first two lines establish the patriarchal economic dialectic - the patriarch raising slaves and children, the latter then doing the same. This is arguably the primordial and central transaction undergirding the macroeconomic shifts coming further on in the poem. Slave bodies are thus the transacted commodity (in the form of labor) permitting further historical economic transactions, circulating from patriarch to his children and from black families to the white-dominated economic structure and surplus value. In this sense, we can also read the second line as syntactically mirroring the first - 'slaves raised slaves' - for patriarchal appropriation. Throughout the poem, the plantation owner/slave master is always the subject of exchange, including during the geographic and economic shift across sugar, mining, and coffee. Subsequently, the concentration of power remains the same and simply reformulates itself through the extraction and production of different commodities.

The next line demarcates the spaces involved in the shift from one crop/ resource to another: from the Surinam cherries native to the northeast coast of Brazil where the sugar economy was based, to the jabuticabas of Minas Gerais, site of the extraction of silver, gold, and diamonds. Finally, we arrive at coffee, the commodity that would dominate the Brazilian economic structure and whose largest landowners would wield political power well into the twentieth century. Notably, this transition also traversed Brazilian independence and cemented the economic structure of the nation. The poem and its placement in the collection, opening the chapter on colonization, posits independence - the advent of the Brazilian empire - as a continuity of colonialism with a similar economic structure, rather than as a historical break or the birth of a new narrative. 
The majority of the remaining poems of the 'Colonização' chapter articulate, in fragmentary fashion, the quotidian acts of violence against slave bodies that were central to the colonial production of the nation. Each poem speaks of a different case, setting, or interaction. They can be read as sequential episodes or as disordered vignettes of violence, exploitation, surplus value, and the reproduction of otherness over black bodies. For instance, the second, third, and fourth poems proceed as follows:

\section{fazenda antiga}

O Narciso marcineiro

Que sabia fazer moinhos e mesas

E mais o Casimiro da cozinha

Que aprendera no Rio

E o Ambrósio que atacou Seu Juca de faca

E suicidou-se

As dezenove pretinhas grávidas.

negro fugido

O Jerónimo estava numa outra fazenda

Socando pilăo na cozinha

Entraram

Grudaram nele

O piláo tombou

Ele tropeçou

E caiu

Montaram nele.

o recruta

O noivo da moça

Foi para a guerra

E prometeu se morresse

Vir escutar ela tocar piano

Mas ficou para sempre no Paraguai. (123-24)

\section{[old plantation}

Narciso the carpenter

who knew how to make mills and tables

Plus Casimiro in the kitchen

who learned in Rio

And Ambrósio who attacked Mr. Juca with a knife

and killed himself

The nineteen pregnant black girls. 
runaway black man

Jerónimo was at another plantation

Working the pestle in the kitchen

They entered

They grabbed him

The pestle fell

He tripped

And fell

They jumped on him.

the recruit

the girl's fiancé

went to the war

and promised that if he died

he would return to hear her play the piano

But he remained in Paraguay forever.]

We can read the events related in 'Negro fugido' and 'O recruta' as having some, perhaps contextual, relation to those of 'fazenda antiga', their action having potentially also occurred in the titular old plantation. Nonetheless, placed within Pau Brasil and within Oswald de Andrade's oeuvre, the events serve metonymical purposes, standing in for experiences and violent acts lived by many more individuals in bondage.

Aside from including some of Oswald de Andrade's more explicit poems regarding the violence of history, the collection also temporally dovetails with the publication of Gilberto Freyre's problematic arguments in Casa Grande e Senzala [The Masters and the Slaves] (1933), romanticizing Brazilian slavery and the relations between masters and slaves. Oswald de Andrade's take on slavery is quite distinct, however. His poems convey an image of slavery as an inescapable social base, superstructure, and culture that produce an unsustainable existence for the bodies and subjectivities over whom it exercises its power. Not even Ambrósio - who kills Seu Juca, presumably his master or overseer, seemingly overturning their relationship and destroying its power dynamics - can elude the death sentence of slavery. Existing in Empire, encompassing slavery while being reproduced by it, is articulated as inhospitable, with no effective means of victory and overcoming, for the subjects it most brutally exploits. This of course carries significant repercussions for the viability of subaltern, slave, and slave-descendent lives in the nation, one imperially engendered through slavery.

At the end of 'fazenda antiga' we are left with a remainder in the form of 'nineteen pregnant black girls,' which seemingly stands for the 
sexual reproduction of slave labor and the field of meanings undergirding its exploitation. The flow of the poem seemingly points to a connection between Seu Juca (and perhaps even his death) and the girls, arguably tying the former to the pregnancies of the latter; the elliptical unsaid presence being the specter of sexual violence at the core of this relationship. The poem's order of actions would thus offer a reflection on the construction of hegemonic white masculinity and, therefore, its articulation as standard gender performance, in the shape of the master. Such a construction is carried out against the masculinity of the enslaved man, relegating black gender performance as 'failed' vis-à-vis the white gender binary. This clash of masculinities also establishes a heterosexist norm in which black female bodies serve as capital for the performance of masculinity. Establishing this norm effectively overlaps with barring black bodies from performing it. This cementing of racialized gender identity also implies the lawful or cultural sanctioning of white male bodies to carry out its excesses. Slavery's culture of white enablement and dominant division of gender roles, positing black female bodies as violable by white masculinity while also being affective property of black men, renders the rape of slave women also an exercise of power over black men within the white heterosexist framework of family structures.

Oswald de Andrade thus seems aware, at some level, of the ways in which black women are multiply ensnared within slavery - as labor toward surplus value, reproductive labor for the existence of a surplus labor force, and capital for the interracial construction and production of dominant masculinity. The poem therefore offers some early insight into the performance and establishment of white heterosexist masculine agency, and its presence at the violent core of Brazil's imperial formation.

The following poem, 'Negro fugido,' begins by conveying the ubiquity and continuity of such violence - the reference to 'another plantation' where the runaway slave is found also underscores such widespread practices. ' $O$ recruta,' meanwhile, seems to point to what was then a well-kept secret among national elites: the sending of male slaves to the Paraguayan War. Although the cultural practices mentioned in the poem point to privileges associated with slavocratic whiteness (i.e. the bride-to-be playing the piano), Oswald de Andrade's placement of the poem asks the reader to identify the experience it relates as a continuity of other experiences of slavery charted in the accompanying poems. Furthermore, the title seems less related to the life of a master's offspring than to the life of a male slave, the former usually being symbolic volunteers in the military. The recruitment of slaves and black freedmen into the Brazilian armed forces for the empire's mission in the Paraguayan War illustrates the postcolony's use of slaves as instruments 
of war and, in the case of this particular war, the empire's performance of national power on the continental stage (Skidmore 88).

The recruitment of slaves as military labor further indicates the discardability of African descendants for the imperially guided postcolony. For the nations involved, the conflict, as has been argued among historians over the last century, represented a eugenic opportunity of preserving the white population while compromising their respective communities of African descent. This has been especially debated regarding Argentina (Geler 214). 'O recruta' suggests that similar discourses of whitening may have surrounded the drafting of Afro-Brazilians into the war, thus signaling a beginning of the eugenics era in Brazil, especially as early eugenic thought was already circulating in Europe and the Americas.

Eugenic thought and public policies were cemented as part of a modernizing endeavor in the final years of the Brazilian empire into the first half of the twentieth century - that is, modernizing (read whitening) the population in accord with imperial standards of progress and civilization. Oswald de Andrade also includes, of course, this period of Brazil's relation to Empire. In a later section of Pau Brasil, titled 'RP1,' named for the São Paulo state train line, 'Rápido Paulista' [São Paulo Express], Oswald narrates a diverse and discrepant array of national geographies marked by intersecting historical phenomena such as industrialization, post-abolition, mass immigration to Brazil, and urban development occurring under the aegis of social and political elites during the first republic. These shifts marking the landscapes through which Oswald's poetic gaze circulates in this section were indelibly guided by fin-de-siècle discourses of modernization - in terms of economic sectors (agrarian to industrial), political structure (monarchy to republic), urban infrastructure and architecture (colonial to modern European), and demographic policies (whitening the national population). In this sense, the tenets of eugenic discourses of human progress overlapped with other modernizing initiatives of the time, if not informing them.

Part of the 'RP1' section, the poem 'Guararapes,' presumably named after the municipality in western São Paulo state, outlines the growing ethnic diversity of the time. The evoked official space, however, is arguably a synecdoche for the growing immigration into Brazil, while also laying bare the dominant narratives of racial difference and whitening that guided how such diversity was understood:

\section{guararapes}

Japoneses

Turcos

Miguéis 
Os hotéis parecem roupas alugadas

Negros como num compêndio de história pátria

Mas que sujeito loiro. (142)

\author{
[guararapes \\ Japonese \\ Turks \\ Miguels \\ The hotels resemble rented clothes \\ Black people as in the history books of the national past \\ But what a blonde subject.]
}

The binary constituted by the final two lines reveals the goals behind integrating the identities of the first three lines into the nation-sign. ${ }^{1}$ The binary also implies a eugenic dialectic of population shift through which the nation arrives at the 'blonde-haired' absolute subject of imperial history, thus leading to the postcolony's shift from object of Empire to subject. As the penultimate line indicates, under this process of racial modernization, blackness is gradually erased and relegated to a distant past portrayed only in history books.

Within the proceeding sections of Pau Brasil, intermingled with poems relating travels through parts of Europe ${ }^{2}$ are accounts of urban modernization, city life and the division of labor, and the national economic shift from agrarian production to massive industrialization, including the new ways in which conditions of subalternity are created. The rich content of these historical reflections consistently pinpoints the Eurocentrism and imperial discourses that inform not only the aforementioned national changes, but the aspects of everyday life they have brought about - from shopping and eating to working and spatial movement.

In charting this imperial formation, and reformulation, of what became Brazil, Pau Brasil uncovers the connected sequences of violence - from the quotidian to the trans-temporal and institutional - as the historicizing acts and material foundation of the reproduction of imperial power in Brazil. These different forms of violence not only maintain the exploitative structure of labor, but also prop up the field of meaning in which they

1 Although a first name, 'Miguel' is arguably deployed here as a reference to Portuguese and Spanish immigrants after independence as São Paulo's coffee industry expanded.

2 Brazilian literary critic Jorge Schwartz points out the importance of travel in Oswald de Andrade's poetry and how his exilic experiences impacted his work (55-57). 
occur, repeatedly creating and placing subaltern bodies into subaltern signifiers as violable beings. In this sense, in his genealogy of (post)colony, Oswald de Andrade elaborated a history of Brazil within Empire, notably in contrast with that of Gilberto Freyre, that also includes the multidimensional, ubiquitous, and quotidian violent forms of imperial signification.

For later genealogies of Brazilian formation, such as those of Freyre, the creation and success of a revised history, particularly one that ensures continuity in the imbalanced distribution of power, is based on fomenting historical misrecognition among national subjects; namely via erasures of the violent modes of reproducing power. Oswald de Andrade thus offers an exploration of Brazilian formation centered on the machinations of power and the meanings it simultaneously engendered, from the earliest moments of imperial historicization of the territory that would become Brazil and the extraction of its first imperially circulated primary resource - Brazilwood. On another note, Oswald de Andrade's Pau Brasil project offers evidence that he did in fact incorporate Afro-Brazilian history and experiences into his vision of a potentially decolonial Brazil, or in his potentially decolonial revision of Brazilian history.

The decolonial potential of Pau Brasil lies in its historicization of not only the ways in which Brazil was formed as imperial sign and space, but how it was historicized - how the signifying chain of Brazil, itself part of a larger signifying chain of Empire, was elaborated across centuries. The anthropophagic poetic voice of the collection consumes the chain that was created but, more importantly, lays bare the processes by which it was articulated, making connections (via fragmented pieces of official historicization intersecting with gaps) between writing and epistemic violence (as in the first section, 'História do Brasil'), physical violence over the body (in 'Poemas da Colonização), and contemporary forms of imperial disenfranchisement including industrial exploitation and urban displacement.

In consuming and historicizing the imperial genealogy of Brazil with its violent modes of signification, Pau Brasil offers different meanings to Antropofagia's cannibal metaphor. Many scholars of the movement have explored the relationship between the metaphor and the consumption of the father/paternal signifier in Freud's Totem and Taboo, of which Oswald de Andrade was evidently a reader. As Maria Cândida Ferreira de Almeida points out, such a reading underscores a redistribution and reordering of goods, bodies, and meanings: 'um alto canibalismo produtivo, já que a morte do pai leva à distribuição das mulheres entre os filhos, e portanto, a sua reprodução' ['a productive cannibalism, since the father's death brings the distribution of women amongst his children, and therefore, his very 
reproduction'] (79). Taking this reading even further, Vinkler underscores the manifesto's rethinking of the patriarchal Oedipal triangle through the union between anthropophagic mother and child - 'filhos do sol, mãe dos viventes' [children of the sun, mother of the living'] (105; Andrade, 'Manifesto Antropófago' 3).

Patriarchy in the manifesto is, moreover, an intersectional edifice contributing to the productions of whiteness and capitalist exploitation in which white heteronormative masculinity's universality is couched. In 'Manifesto Antropófago,' I would argue, the father explicitly represents a master signifier in the realm of Empire - simultaneously the crystallization of power, the site of normativity, the regulating gaze of intersubjective life, and the epistemological location of historicization.

Enrique Dussel notably synthesizes these Western imperial facets under the aforementioned term 'archetypal foundational "I"' (8). He also traces the emergence of this entity through which imperial European thought presents itself, as well as its philosophical reformulations through Descartes's ego cogito and Kant's ich denke. Within Empire, the archetypal foundational 'I' is thus a site of both knowledge and desire, establishing itself as archetype while reproducing the imperial field of meaning in which it resides through the dialectical repetition of otherness. As such, it both voices and represents the imperial standard and the universal articulated through the intersecting categories of personhood - whiteness, bourgeois, masculinity, heteronormativity, and ableism.

In this sense, the cannibal metaphor, in consuming the signifying chain of Empire, also consumes the greatest composite of this history - the figure of Man and the foundation/imago of European humanism, in its gender binary rigidity, racialization, heteronormativity, ableism, and bourgeois existence. There is, in other words, a consumption of a person in Oswald de Andrade's cannibal metaphor. Instead of the Bishop Sardinha, though, it is the ego cogito of imperial rationalism that is consumed. The result of this consumption and digestion, though, is open-ended. Oswald does not give us a clear picture of what emerges from the devouring and the critical interpretation of the cogito's emergence.

It is on this particular point that my reading of Oswald de Andrade's anthropophagic work diverges from that of Silviano Santiago, who reads his invention of Antropofagia as 'a creative attempt to incorporate his production into a universal movement' (Space 61). Reading Pau Brasil in the context of Empire points toward an arguably more destructive, deconstructionist, and open-ended political project vis-à-vis universality. Instead of inserting Pau Brasil into a universalist movement, or even articulating a nascent universalist movement, the cannibal consumption of an imperial 
signifying chain and its archetypal scene of knowing, desiring, and writing suggests a strategic avoidance of universalisms and their totalizing discourses. This would leave the next phase of consumption - reformulation - open to further possibilities, that is, different forms of queering and altering historicizing gazes. After all, the goal of erasing the father/Empire's master signifier - the voice, gaze, and embodiment of Empire's Law - is to give impulse to a post-Oedipal subject's signifying process. In this regard, Oswald de Andrade's Antropofagia is less about enunciating a direction in peripheral cultural production and thought than opening, against Empire's field of meaning, the possibility of new cultural discourses and subjectivity.

\section{Consumption, Repetition, and Allegory}

Oswald de Andrade's Pau Brasil collection, particularly its anthropophagic poetic voice, enacts in many ways the cannibal praxis later outlined in his 'Manifesto Antropófago.' The collection effectively puts into action the allegory of historical consumption through a repertoire of narrative devices including fragmentation, synecdoche, ellipsis, and historical repetition. Oswald de Andrade's poetics of repeating both signs and their moments of articulation adds yet another layer to the deployment of allegory within the problematics of postcoloniality. Schwartz pinpoints the aesthetic strategy of this repetition, centuries after the original moments of imperial articulation, in some cases. Temporal distance, he argues, 'cria o efeito paródico e de estranhamento. Este novo olhar sobre o Brasil [...] recria o impacto colonizador frente aos indígenas, a flora e a fauna brasileiras' ['creates a parodic effect as well as one of estrangement. This new gaze over Brazil recreates (...) the colonizer's impact over indigenous peoples, the flora, and the fauna of Brazil'] (57).

Repetition, Paul de Man would later argue, is crucial to the function of allegory:

this relationship between signs necessarily contains a constitutive temporal element; it remains necessary, if there is to be allegory, that the allegorical sign refer to another sign that precedes it. The meaning constituted by the allegorical sign can then consist only in the repetition [...] of a previous sign with which it can never coincide, since it is of the essence of this previous sign to be pure anteriority. (207)

For de Man, this repetition of signs within allegory creates a temporal and, subsequently, semantic disjuncture between them - the temporal gap in enunciation disfigures the previous meaning of the sign. The deeper 
repercussion of this is that notions of origin are radically compromised by the allegorical translation of the sign across time. Allegory, for de Man, 'designates primarily a distance in relation to its own origin' (207). Furthermore, the loss of origin, or access to it, complicates identity and selfhood, since 'it prevents the self from an illusory identification with the non-self, which is now fully, though painfully, non-self' (207). In reiterating colonial and postcolonial History in this fashion, Oswald de Andrade's poetics function as both narrative and metanarrative, simultaneously; the latter always questioning the former, producing the former as an ideological reality of perpetually emergent possibilities of inscription. History is now related in a fashion that compromises its site of articulation, as 'a radical series of discontinuous interruptions' (Spivak 208). The same can be said of the blank spaces between Oswald's poetically re-narrated fragments, standing for the place of the reader's interpretational agency. After all, the anthropophagic reader is supposed to connect (or not) the fragments and the titles, filling in the gaps of the narrative left for the productivity of new emergent gazes.

At the collective level of postcoloniality, Oswald de Andrade's use of allegory turns this temporal void between repetitions and away from origin into a productive space of decolonial historical articulation for the postcolony. The postcolony emerges from the ruins of Western imperial narrativization as a space of displaced origins, permitting the affirmation of subject positions away from modernity's Western 'archetypal foundational I.' The void produced by repetition becomes a site from which subaltern knowledges can write. In this light, Oswald de Andrade does not seek to recover or uncover a precolonial identity, Amerindian or otherwise, as some criticism has argued. Rather, the goal is to leave all identity unstable, whether it takes the form of a national consciousness or the fantasized sign of otherness. Identity, as it were, implies a unified and constant place in the signifying field, a false image from which further signification occurs. In this regard, one can argue that the postcolonial objective of Antropofagia, as Mário and Oswald seem to envision it, calls for a heightened awareness of the tyranny of fixed identity vis-à-vis the signification of intersubjective reality. In other words, the fantasy of a fixed identity always tends to imply a related fantasy of fixed meanings in the symbolic realm of intersubjectivity.

Through the repetitive exercise of allegory, anthropophagic thought arrives at the significationally disruptive nature which Bhabha attributes to his theoretical reconceptualization of hybridity, 'interven[ing] in the exercise of authority not merely to indicate the impossibility of its identity but to represent the unpredictability of its presence' (163). By articulating History, parodizing and parading its false totality, Oswald de Andrade evokes a 
new ontological space that disfigures Dussel's 'archetypal foundational I' from which the 'coloniality of power' is proclaimed and carried out in the postcolonial present. The second part of Bhabha's point is far more sobering, pointing toward the conservative possibilities of significational postponement: 'the sign of the productivity of colonial power, its shifting forces and fixities' (160). In postponing, repeating, and doubling, authority's presence potentially becomes further unpredictable since it also potentiates new possibilities for imperial inscription.

Oswald de Andrade's opening line in 'Manifesto Antropófago' - 'Só a Antropofagia nos une' ['It is only Anthropophagy that unites us'] - has been appropriated by opposite ends of the cultural power spectrum to articulate a hybrid Western or European global narrative, occulting violent interracial encounters and relationships while, more crucially, sublating difference into a more complex totality of imperial narrativization. Toward the middle of the manifesto, Andrade declares: 'Contra as sublimações antagônicas. Trazidas nas caravelas' ['Against antagonistic sublimations. Brought on the caravels'] (3). He seems all too aware that the imperial power of writing cannot be fully halted, due to the material conditions of economic, political, and cultural domination, but seems to suggest that it can, nonetheless, be repeatedly challenged. In this regard, Antropofagia calls for decoloniality to carry out a sustained significational battle to consistently interrupt Western historicization through critical evaluations of Western meaning. Postcoloniality, therefore, is as much a politics of reading as of writing and rewriting. Both, in fact, are parts of the same radical politics of allegory - to constantly interpret is to constantly reconfigure meaning. The movement's fundamental and titular allegory (to consume and recreate) thus underscores the agency in interpretation. Instead of copying an image or signifier, postcolonial subalternity is called upon to take a critical distance in reading the signifier, creating an aperture in signification at the moment of postponement, and repeating it into a shifted figure. Allegory, then, is not only a potentially dissident act of writing, but also, and perhaps primarily, of reading/consuming.

In this regard, the agency of devouring or consumption (of meaning) becomes Oswald de Andrade's own tweaking of dialectical materialism. After citing various passages from Marx, Engels, and Lenin, he declares: 'Nada existe fora da Devoração. O ser é a Devoração pura e eterna' ['Nothing exists outside of Devouring. Being is pure and eternal Devouring'] (Estética 286). This becomes a philosophy of decolonial subjectivity in that the subject becomes potentially radical through interpreting meaning and remolding it. The moment of repetition seems to suggest that the way to counteract Western history and Western historicism is not simply to 
produce alternative or counter-histories but to contest and inflect the more far-reaching implications of the system of which they form a part' (Young, White Mythologies 215).

\section{Conclusion}

Allegory, as an aesthetic form, inevitably implies a political stance in its deployment within the quotidian of coloniality in the postcolonial nation - a sign informed by imperial signification. The mode of aesthetic articulation explored in the texts above seeks to displace not only this brand of meaning but its historically constituted gaze through the archeological recovery and repetition of fragments of such a historical narrative and its narrativization. As we have discussed, the act of repetition, by removing the signifier from one context to another, destabilizes both the fantasized fixity of the signifier and the fantasized totality from which it was extracted. This includes the implied signifying gaze of Western History, in favor of an anthropophagic one that also begs to be repeated and allegorized in future moments of enunciation, thus establishing a historicizing mode that occludes any fixity of the signifying voice of national postcoloniality. Therefore, the sign of the nation can be perpetually resignified without a historically specified scene of writing in control of its reality. In other words, Oswald de Andrade's anthropophagic work does not simply rethink Brazilianness vis-à-vis Empire; it aims, rather, to open a historical fissure in Empire's signifying chain through which this rethinking may continue through the concomitant emergence of new scenes of writing; or, as Bhabha puts it, "to reconstitute the discourse of cultural difference demands not simply a change of cultural contents and symbols [...]. It requires a radical revision of the social temporality in which emergent histories may be written, the rearticulation of the "sign" in which cultural identities may be inscribed' (246).

The following chapter will further explore how the anthropophagic voice and decolonial mechanism operates in Macunaima, taking the famous chapter 'Carta prás Icamiabas' ['Letter to the Icamiabas'] as the embodiment of the Antropofagia project as well as the rule by which Mário de Andrade measured the movement's limitations. Through this particular chapter, I argue, Andrade performs an experiment in elaborating a tentative decolonial scene of writing, fraught with both limitations and new political possibilities. 


\title{
Mário de Andrade's Antropofagia and Macunaima as Anti-Imperial Scene of Writing
}

\begin{abstract}
$A s$ in the case of Oswald de Andrade, in the work of Mário de Andrade $\mathrm{A}_{\text {produced during his 'anthropophagic period,' one finds a sustained }}$ aesthetic project in which the experience of colonialism emerges in different pieces and fragments. In the work of Mário de Andrade, the experience of Empire is rendered in the plural, particularly as a multiplicity of subject-positions that form postcoloniality. In his body of work, moreover, one finds these polyphonic experiences of colonialism translated into an unspecific ontological place from which to articulate the postcolony. In his famous modernist novel from 1928, Macunaíma: Um Herói Sem Nenhum Caracter, the titular character - 'herói de nossa gente' ['hero of our people'] (9) - embodies the collision between the colonially historicized past and Mário's industrial present.

Although many scholars and even Mário de Andrade himself would later question the location of his novel within the Antropofagia archive, it nonetheless shares the tenets of the cannibalist movement - namely the consumption, rethinking, and underlining of gaps of imperial meaning. In a cogent defense of reading Macunaima as a contribution to Antropofagia and as an embodiment of its aesthetic and political goals, Zita Nunes argues that:
\end{abstract}

The novel enacts cannibalism on: 1) a textual level by incorporating other texts through plagiarism; 2) a linguistic level by incorporating other languages into Portuguese; 3) a thematic level through cannibalistic activities of its characters; and 4) on a formal level by incorporating various genres into the novel, producing what Mário called a 'rapsódia' (rhapsody), an improvisational composition having no fixed form. (41)

Drawing on and further exploring the critical potentials of these aspects of Macunaima, what follows will expand on Antropofagia's engagement with Empire while also discussing its limitations and ultimate shortcomings, through the gaze of Mário de Andrade. 


\section{Macunaíma:}

\section{Allegorical Movement through Time and Space}

As Albert Braz reminds us, Macunaíma is not entirely Mário de Andrade's creation, but firstly an Amerindian mythological character. Moreover, de Andrade seemingly (re)constructs Macunaíma, at the beginning of the novel at least, as the intersection of different subaltern experiences within Brazilian colonial history, intertwining Amerindian indigeneity with blackness, and not without problematic signifiers of otherness. His epic journey begins as he is born in an unnamed forest, the youngest of three brothers of the fictional Tapanhumas tribe. Macunaíma and other members of the Tapanhumas are described as 'retinto' ['dark-skinned']. This leads K. David Jackson to classify Macunaíma as 'multiracial' (96). In this regard, Macunaíma embodies the anthropophagist mission of establishing a postcolonial scene of writing - as the syncretistic figure of the plural experiences of imperial power in colony and postcolony.

It is through Macunaíma's significational gaze - one that consumes and signifies - that we read Westernness as he encounters it in his journey from the forest to the city in search of a precious amulet given to him by the goddess Cí. At various points in the novel, the reader finds Macunaíma's encounters with Western signifiers regarding Brazil pertaining to race, indigeneity, and space. From these confrontations, Macunaíma takes on Antropofagia's mission of reordering these signifiers.

The journey away from the forest begins with a fascinating early scene that captures the allegorical verve of the novel. As Macunaíma and his brothers, Jiguê and Maanape, make their way toward industrialized São Paulo, they come across the magical water pit formed by the giant foot of Sumé, a mythological figure from Tupi folklore, where they decide to bathe, one at a time. The first to enter the water, Macunaíma quickly discovers that it magically whitens his skin, washing off his blackness. The three rejoice in the water's race-altering properties. Having entered the water first, however, Macunaíma absorbs most of its power, also staining it with his former blackness. Subsequently, Jiguê, the second to enter the water, is only able to whiten his skin enough to become 'vermelho' - red-skinned or Amerindian. Maanape, finally, is merely able to lighten the skin of his hands with the shallow dark water that did not splash out during the baths of Macunaíma and Jiguê. This complex scene allows us to explore various layers of the novel's allegorical form within a postcolonial epic model which Mário de Andrade was aiming to engender. Macunaíma's passage through the novel's diegetic time-space marks his passage through discourse and Brazilian historicity; here, in the footprint of Sumé, he enters the 'magical' 
world of racial signification, finding himself within realms of othering that came to structure Brazilian society.

This passage perhaps also represents a tacit critique of the work of other members of the Antropofagia movement, namely those who offered multiculturalist narratives of Brazil while marginalizing Afro-Brazilians. Some of the artists, writers, and poets who participated in Antropofagia produced their own modernist epics and blueprints for a 'Brazilian-Brazil.' Many of these works, including Raul Bopp's Cobra Norato, Cassiano Ricardo's Martim Cererê, and numerous works by members of the Verde-Amarelismo [Green-and-Yellowism] nationalist movement (that broke away from Antropofagia) such as Plínio Salgado and César Menotti del Picchia, construct national identity through a mythical Tupi figure. This idealization of the Tupi, however, seeks a national origin through a precolonial fantasy. This is where Mário and Oswald de Andrade offer a more nuanced decolonial project. Rather than conceiving a central signifier that purports to convey a precolonial origin, Mário's and Oswald's respective work suggests that such an origin is untenable, and that any articulation of one is inevitably constructed through imperial knowledge and writing about the Tupi. The decolonial path, therefore, begins with a reading or decolonial consumption of the field of meaning produced by Empire. In the case of Macunaíma, the journey begins with an experience of the imperial categories of race, not prior to such categories.

History, and how Macunaíma travels through it, emerges in the novel as a temporal mash-up. From the forest where racial difference is presented to him, he moves to the modern industrialized city. Time is articulated by means of spatial crossings, while historical moments are unfolding in seemingly simultaneous movement. The (discursive) machine of History thus resembles a sort of theme park attraction transporting protagonist and reader across periods.

Spatial movement, so integral to the epic genre, is therefore crucially multilayered. Furthermore, the construction of the novel's titular character develops a deeply ambivalent sort of epic. As the novel's subtitle indicates, he is a 'hero with no character.' His diegetic centrality is always already in dialogue with the decentralization of the behavioral makeup of a Western epic protagonist. More importantly for our concerns here, the allegorical protagonist lacks the key element of the traditional epic hero, often manifest at the plot's closing - mastery over intersubjective reality. Herein lies the postcolonial challenge of nationhood that Mário de Andrade aims to articulate, in which the sign of the nation attempts to make sense of the History (imperial narrativization as intersubjective reality) into which it has been inserted. 
As Walter D. Mignolo elaborates, drawing on Aníbal Quijano, the coloniality of power transcends locality and 'goes beyond decolonization and nation building: coloniality is the machine that reproduces subalternity today in the form of global coloniality in the network society' ('Coloniality' 426). Mário de Andrade's Antropofagia opens a historical fissure through which this brand of coloniality can be challenged, namely in terms of local power that inserts the postcolonial nation into the global network. In his deeper elaboration of coloniality of power, Mignolo addresses the relationship (in terms of cultural and economic politics) between Latin America and the West as one in which the former is historically constructed (in both colonialism and postcoloniality) not so much as the latter's other, but its Occidentalist extension (Local Histories 58). One can sum up Brazil's Tropical Belle Époque - in its cultural, architectural, and political being as a sustained bourgeois project of inserting the postcolonial nation into modernity and the West. In this light, the Tropical Belle Époque (on the heels of which emerged Antropofagia) extended the West not only spatially but temporally. Through declaratively contesting the narrativizing gaze of the West, the Antropofagia movement can be thought of as an early form of post-Occidentalist discourse, devised almost a half-century later by Roberto Fernández Retamar ('Nuestra América').

Within the allegory of the epic character traveling through historicization emerge further long-established allegories of Brazil's colonial and postcolonial formation. Most notably, the aforementioned scene of the magical water in Macunaima can be read as a complex questioning of the national myth of the three races in which Brazilianness is founded upon the multicultural exchange between Europeans, Amerindians, and Africans. The radical reformulation of this particular allegory implies a rewriting of postcolonial national thought that had been articulated from historically privileged subject-positions. More than highlighting the historical centrality and subsequent desirability of whiteness within the multiracial national narrative, the novel's parody of the original allegory lays bare the ontological site from which such postcolonial narratives emerge, while underscoring racial inequities occulted therein. These are inequities upon which nationhood has been founded. In this regard, the novel pre-emptively challenges the national/societal myth of 'racial democracy' that Brazilian sociologist/anthropologist Gilberto Freyre was already developing and later set out in his ambitious treatise on Brazilian national formation, Casa Grande e Senzala (1933). In arguing that Brazilian society lacks racial prejudice and post-abolition institutional disenfranchisement, especially vis-à-vis the United States' Jim Crow South, white masculine elite subjectivity nevertheless emerges in Freyre's historical argumentation as the de facto agent of Brazilian history and historicity. 
This relationship between whiteness and historicization informs Macunaima's allegorical scene at Sumé's water pit in which the pigment-altering contents of the pit are tied to the sign of whiteness in this scene and to the construction of its own privilege; that is, to the right to signify. In quantitative terms, postcolonial whiteness is synonymous with access to History and historicization in its entirety, while blackness in the postcolonial Western nation is articulated in terms of relegation, that is to the vestiges of History. Instead of conveying subalternity in spatial terms of historical center and periphery, this passage of the novel brings forth History in terms of volume. Similarly, rather than the subaltern being 'written out of history,' Mário de Andrade suggests that the relationship between History and subalternity is more complex. In the scene in question, the subaltern is inside of History, that is, as a historical being, but not a historicizing one. The subaltern's place within the signifying field of History is that of the written sign, as opposed to the sign that writes; as inscription, not inscriber. The privileged double function of historical agency ultimately belongs to the whitened Macunaíma - enunciator of self and other within History. Tellingly, he quickly comments on Jiguê's inability to become white: 'Olhe, mano Jiguê, branco você não ficou, porém pretume foi-se e antes fanhoso que sem nariz' ['Look, brother Jiguê, you did not become white, but your blackness is gone and it is better to be nasally than nose-less'] (Macunaima 48). While whiteness is to be desired and attained, blackness here is its dialectical abject other, to be avoided, a reference to eugenicist and racial scientific thought prevalent among Brazilian elites.

Jackson's reading of the passage underscores part of its larger racial commentary: 'as a result of this episode Macunaíma is the best prepared to enter "civilization," while "Manaape is said to be the true son of the Tapanhumas: a combination of black and red' (97). Macunaima has largely been read as gesturing toward a multicultural narrative of Brazilian nationhood, but that is merely one of its many significational and self-reflexive layers. In attempting to engender a decolonial site of consumption or scene of writing, the novel's narrator, in controlling and toying with the relationship between the novel's diegetic space and that of imperial History, consistently asks the reader to be cognizant of imperial meaning's impact on multiculturalist discourse.

We can also read this passage of Macunaima through the lens of parody, a narrative device which Maria Eugenia Boaventura suggests is central to the aesthetic and political ends of the Antropofagia movement: 'transforma-se a paródia em modo eficaz de expressão, típico de uma civilização em estado de transição' ['parody is transformed into an effective mode of expression, typical of a civilization in a state of transition'] (23). Drawing on Boaventura's 
argument, Antropofagia and the modernist period of cultural production in Brazil both enact and critically reflect on the transitions proposed. The parodic device both constitutes and engenders (in the reader/viewer) a new form of understanding the myth as a piece of historicization, and thus a potentially revised relationship between reading subject and discourse. In contesting a particular myth, greater myths may subsequently crumble. In other words, in rethinking such a celebrated fragment of a hegemonic historical narrative by laying bare the imbalances behind it, the larger myth of a totalized monolithic History is possibly interrupted.

It is this sort of engagement with imperial consumption and signification that I find to be the key to understanding both the novel and Mário de Andrade's larger anthropophagic project. His elaboration of Macunaíma through what scholars and cultural critics have considered primitivist attitudes reflects his (more than most other members of Antropofagia) critical gaze upon the signification of otherness within nationalist ideologies. Macunaíma, the character, is of course extracted from Theodor Koch-Grünberg's ethnographic account of indigenous peoples in the Amazon and Mount Roraima in Venezuela, published in 1917. As a critical reader of colonial discourse, Mário deploys Macunaíma not as a national symbol, but as a nuanced reading of European knowledge in its intersections with Latin American multicultural and hybrid national narratives. Any critical reflection of nationhood must begin with an engagement against European consumption and signification of the (post)colony.

Imperial consumption emerges in many ways throughout the novel, both at the level of historical and ethnographic texts with which Andrade dialogues, but also within the diegesis through its characters. The most explicit example would be Macunaíma's principal nemesis, Venceslau Pietro Pietra, a Peruvian capitalist of Italian descent. His nefarious role in social relations is particularly underscored by his corporal stature as a giant. Moreover, as Kimberle López points out, Pietro Pietra 'carries the labels of "gigante" and "Piaimã," appellations which evoke both Iberian and Taulipang legends of man-eaters' (33). Within the plot, Pietro Pietra is thus the consumer par excellence, the collector of precious stones (the embodiment of commodity circulation) and consumer of Brazilian property and labor force. Macunaíma's search for the amulet ultimately leads to his decisive confrontation with Pietro Pietra.

Esther Gabara's in-depth analysis of Mário de Andrade's brand of modernism brings to light his profound engagement with colonial discourse through an intricate dialogue between his literary production, ethnographic work, and photography. In terms of the latter, Gabara offers elucidating readings of Mário's 'practice of portraiture' as one that is strikingly opposed 
to the primitivism that marks European consumption of the Amerindian and Afro-Brazilian other. While much Eurocentric primitivism - including some produced by Latin American modernists - sought to fix, capture, and homogenize the other, Mário's work, Gabara argues, 'strives to avoid capture and record heterogeneity' (66). This is, Gabara concludes, part of Mário's larger project of a 'critical nationalism that developed in opposition to the history of colonial pain' (66). Part of his practice of critical nationalism led Mário de Andrade, more than other modernists, to avoid some of the pitfalls of expressing heterogeneity through an imperial lexicon. This is most notably underscored by his extensive research into Afro-Brazilian and Amerindian communities in order to understand non-imperial narrativizations of time and space. From this research into alternate modes of signification, Mário de Andrade aims for a dialogical scene of decolonial writing that is never one, but multiple.

\section{Renegotiating Transculturation}

Macunaíma's voice, actions, and diegetic configuration are not, therefore, Mário de Andrade's expression of Brazilian identity. Rather Macunaíma as the condensation of imperial racial signifiers (laziness, hypersexuality, and abjection) - represents Mário's denunciation of many of his modernist contemporaries who reproduced such fantasies of otherness. Macunaíma is, at least at one level, truly not a character, as the title indicates, but an imperial fantasy that Mário de Andrade witnessed being appropriated to convey national identity. López points out regarding Macunaíma's nationalism, that his 'inability to commit to a national identity ultimately leads to his death, when Vei, the Sun, still angry because he betrayed her native daughters with a Portuguese fishwife, concerts the hero's fatal encounter with the lady of the lake' (33). Macunaíma, the tentative decolonial scene of writing and consumption, is himself consumed as punishment for not consistently identifying with the mandates of the nation voiced by Vei, who summons the siren Uiara to devour him.

The titular character is thus more a vehicle of critique - of nationalism and its imperial foundations, as well as of colonial discourse as it informs cultural understandings and identity politics. This critique, if we read Vei as the voicing of national desire and surveying of 'national' bodies, also arguably configures nation as a potentially oppressive framework that establishes the parameters of individual identity and desire. In this sense, Macunaíma's trajectory, as a scene of consumption, points to Cândido's positing of nation as a 'recurso ideológico, numa fase de construção e autodefinição' ['ideological recourse, in a phase of construction and 
auto-identification'] (28). The decolonial stance of this scene of consumption and writing would thus include a questioning of the nation in its imperial underpinnings and coercive impact on different identities.

Fernando Rosenberg adds yet another layer to Macunaíma's critical nationalism, crucially pointing out that:

Macunaima doesn't just stop at proposing a cultural mix of its own. It explores the blind spots of these newly hegemonic transcultural narratives. It subjects to scrutiny the strategies of antropofagia, transculturation, and hybridity by referring them to the recurring history of colonial domination that they attempt to nationalize and turn around. (81)

Mário de Andrade's novel, in other words, offers further nuance to existing theories of colonial pasts and presents. Coined in 1947 by Cuban anthropologist Fernando Ortiz, the term transculturación became a conceptual framework for thinking through intercultural and interethnic encounters, especially but not solely those producing the largest impact, such as colonialism and slavery. These encounters, for Ortiz, came to enact 'diferentes fases del proceso transitivo de una cultura a otra' ['different phases of the transitive process from one culture to another'] (90). Ortiz also differentiates transculturation from other phenomena, although these may result from transcultural encounters:

éste no consiste solamente en adquirir una distinta cultura, que es lo que en rigor indica la voz angloamericana acculturation, sino que el proceso implica también necesariamente la pérdida o desarraigo de una cultura precedente, lo que pudiera decirse una parcial desculturacion. (90; emphasis original)

[this does not consist solely of acquiring a different culture, which is what the Anglo-American voice effectively calls acculturation, but also necessarily implies the loss or eradication of a preceding culture, what could be called partial deculturation.]

Notwithstanding the undeniable deculturation or deracination of indigenous groups resulting from European colonialism in Latin America, Ortiz locates mainstream Latin American (more particularly Cuban) cultural production as reflective of the 'creación de nuevos fenómenos culturales que pudieran denominarse de neoculturación' ['creation of new cultural phenomena that could be called neoculturation'] (90; emphasis original).

The latter reflection or version of transculturation is arguably that which has been most appropriated by subsequent Latin American intellectuals to 
theorize the (post)colonial negotiations between metropolitan cultural forms and historical and cultural particularities of Latin American producers. Drawing on, while also expanding Ortiz's conception, Uruguayan theorist Ángel Rama defines the term as implying

una doble comprobación: por una parte registra que la cultura presente de la comunidad latinoamericana (que es un producto largamente transculturado y en permanente evolución) está compuesta de valores idiosincráticos, los que pueden reconocerse actuando desde fechas remotas; por otra parte corrobora la energía creadora que la mueve, haciéndola muy distinta de un simple agregado de normas, comportamientos, creencias y objetos culturales, pues se trata de una fuerza que actúa con desenvoltura tanto sobre su herencia particular, según las situaciones proprias de su desarrollo, como sobre las aportaciones provenientes de fuera. Es justamente esa capacidad para elaborar con originalidad, aun en difíciles circunstancias históricas, la que demuestra que pertenece a una sociedad viva y creadora. (33-34)

[a double verification: on the one hand, it registers that the present culture of the Latin American community (which is a largely transcultured product in permanent evolution) is composed of idiosyncratic values, which can be identified as acting from remote dates; on the other hand, it corroborates the creative energy that moves it, distinguishing it from a simple aggregate of norms, behaviors, and cultural objects, as it implies a force that acts with aplomb over both its particular heritage, according to particular situations of its development, and foreign approaches. It is precisely this ability to elaborate with originality, even in difficult historical circumstances, that demonstrates that it belongs to a vivacious and creative society.]

Rama updates Ortiz's concept by designating an interstitial space occupied by Latin American cultural producers through which the national is in constant flux and negotiation between hegemonic and subaltern production. Dispelling accusations of imitation levied against Latin American artists and writers (such as Mário de Andrade), Rama underscores the profound creative labor undertaken in elaborating this negotiation.

For Oswald and Mário de Andrade's Antropofagia, couched within Brazilian modernism, this negotiation also implies rethinking and responding to the tenets of their contemporaneous modernity - the historical, racial, bourgeois, medical (i.e. eugenic), and urban developmental discourses espoused by national elites - that marked the late nineteenth and early twentieth century. As we saw in the case of Oswald de Andrade, and will 
explore in the context Mário de Andrade's Macunaima, contesting this modernity requires a historical revisiting in the form of a cannibal genealogy or critical repetition of Empire's moments leading up to the present. This revision of modernity, undergirded by the aforementioned negotiation between subaltern (not the phantasmatic precolonial Tupi, but the displaced Tupi, the enslaved Afro-Brazilian subject, and the urban proletariat, to name only a few) and hegemonic knowledge, suggests an open-ended and indeterminate process of rethinking the modern order. In doing so, room is cleared for hybrid - to borrow Bhabha's term - cultural production and identities emerging from the imbalanced encounters between cultures and knowledges. Bhabha's theoretical artifice, hybridity, names the myriad sites of this negotiation between subaltern and hegemonic in the context of Empire. The concept is predicated, moreover, on the indeterminacy of the sign, what Jacques Derrida calls différance, the postponement of meaning between subject, reading of the sign, and reinscription (145-70). In this sense, transcultural negotiations imply the repetition of imperial signs, each moment of repetition representing an opportunity for resignification; and from there, the possibility of reformulating subjectivity in regard to Empire.

What Mário and Oswald de Andrade contribute to these debates is the notion that their contemporary Brazil is not composed of one single Brazilian culture or knowledge that negotiates between an inaccessible precolonial past and modern European politics and aesthetics. Rather, this endless transcultural process is a nuanced and constant struggle between subaltern identities on the precipice of erasure and dominant imperial/ European models of knowledge and personhood. The transcultural battle is thus undergirded, as Oswald makes clear in 'Manifesto Antropófago,' by Empire, capitalism, and patriarchy; and, therefore, the resignification and/or contestation of modernity must not be undertaken by national cultural elites (including himself) but by the existing knowledges that have experienced and are under persistent attack by the political, economic, and representational forces of Empire. One can tie this approach to transcultural negotiation to Mário de Andrade's contributions to political and institutional landscapes, namely his role in the creation of the University of São Paulo and his founding and directorship of the Department of Culture in São Paulo. As Saulo Gouveia notes with regard to the creation of the latter, 'the main goal of this cultural project was to democratize access to culture' (178).

A transcultural negotiation based on analyzing what colonialism and Western History has left, allows ultimately for the decolonial nation-sign to be articulated and/or constantly problematized. It is worth noting that Mário applied his 'critical nationalism' even to his own sense of national identity, or lack thereof. He often alludes to 'the de-nationalizing anguish of culture' 
that he encounters in exploring Brazilian history. In an unpublished preface to Macunaima, he questions whether he 'made a Brazilian work' (356) and admits, 'I don't know if I am Brazilian' (356).

\section{The Anthropophagic Scene of Consumption}

The larger argument regarding the novel is that, contrary to common readings of it, which arise largely as a consequence of particular understandings of Antropofagia, Macunaíma is not a symbol of a hybridized national identity, but rather a composite of imperial meanings as well as representing an emergent decolonial scene of writing - the anthropophagic subject that produces meaning. Nowhere in the novel is this more evident than in the letter Macunaíma writes from the city of São Paulo to the female subjects of his Amazonian kingdom - the Icamiabas.

In the letter, titled 'Carta prás Icamiabas' ['Letter to the Icamiabas'] and spanning its own chapter in the novel, Macunaíma offers several analyses of European meanings and the Western narrativization of otherness. As noted in the previous chapter, Mário de Andrade claimed to have copied several passages of this particular letter directly from travel texts. Alfredo Bosi considers the letter to be a 'crônica jocosa' ['humorous chronicle'] (400), and an example of the novel's 'estilo de paródia' ['parodic style'] (399). Bosi reads the letter, more specifically, as a parody of pre-modernist Parnassianism in Brazil, namely the writing of Coelho Neto and Rui Barbosa. In Bosi's opinion, the plot's abrupt shifts from primitivism to parody to a distancing from both, '[justifica] plenamente o título de rapsódia, mais do que "romance" que emprestou à obra' ['fully justifies the title of rhapsody more than that of "novel," which he attributed to the work'] (400; emphasis original). The letter's text inevitably lends itself to various interpretations and critiques. Regardless of to whom it may or may not be directed among the readership, the letter is the only instance in which the reader is granted extended access to the transitioning voice of the titular character. The letter is, moreover, a product and example of Macunaíma's consumption and narrativization of São Paulo. The choice of prose, as we will explore, offers further layers of potentially decolonial meanings, as well as warnings on the cooptation of radical movements.

Taking on the role of travel writer, an anthropophagic one who interprets and re-narrativizes the layout of modern power that informs and compartmentalizes urban life at the height of Brazilian industrialization, he writes:

Moram os Paulistanos em Palácios alterosos de cinquenta, cem e mais andares [...] nos bairros miseráveis, surge anualmente uma 
incontável multidão de rapazes e raparigas bulhentos, a que chamamos 'italianinhos'; destinados a alimentarem as fábricas dos áureos potentados, e a servirem, escravos, o descanso aromático dos Cresos.

Estes e outros multimilionários é que ergueram em torno da urbs as doze mil fábricas de seda, e no recesso dela os famosos Cafés maiores do mundo [...]

E o Palácio do Governo é todo de oiro, à feição dos da Rainha do Adriático; e, em carruagens de prata, forradas de peles finíssimas, o Presidente, que mantém muitas esposas, passeia, ao cair das tardes, sorrindo com vagar. (105-06)

[Paulistanos reside in tall Palaces of fifty, a hundred and more floors (...) every year in poor neighborhoods there emerges an innumerable multitude of disorderly boys and girls whom we call 'little Italians', destined to sustain the factories of the golden potentates, and serving the aromatic ease of Croesuses like slaves.

These and other multimillionaires erected the twelve thousand silk factories around the city, and in between the famous, largest Cafés in the world (...).

And the Government Palace is made of gold, in the likeness of the palaces of the Queen of the Adriatic; and, in silver caravans lined with the finest furs, the President, who maintains many wives, strolls smiling and wandering in the late afternoon.]

The counter-historicist project of Antropofagia embodied by Macunaíma's letter aims to enact a critical distance vis-à-vis Western modernity and the signifiers it has produced. The cultural imperative of modernizing national culture - gesturing toward a 'Brazilian-Brazil' - implies a decolonial, non-imperial modernization. The decolonial voice in which the letter is written does not point toward a premodern ideal, nor toward a premodern voice, but to one that emerges through the signifiers of modernity, imperialism, and industrial capitalism - delinking these from their field of meaning and thus interrupting imperial historicity in favor of a decolonial mode of signification.

This gesture exemplifies Walter Mignolo's call for a shift from what he coins a 'geopolitics of knowledge' to the 'geopolitics of knowing' (Darker Side 119) - that is, a decolonial shift from being enunciated within imperial knowledge to enunciating from within its field of power. Mignolo identifies the enunciated as the 'anthropos' - the object of Western knowledge, signified as non-Western otherness: 'The anthropos, in inhabiting non-European places, discovered that she/he has been invented, as anthropos, by a locus 
of enunciation self-defined as humanitas' (Darker Side 119). Macunaíma's letter thus stages the anthropos's discovery 'that she/he has been invented' and the recognition that $s /$ he is 'inside the space and institutions that created him/her' (119). The aforementioned shift taken on by Macunaíma's anthropophagist letter transforms the site of the enunciated, or consumed (as other), into the site of consumption and enunciation. Macunaíma, embodying the object of European consumption and Western imperial power, is flipped and becomes a site or agent of knowing. This shift from knowledge to knowing, Mignolo argues,

is the beginning of any epistemic decolonial linking with all its historical, political, and ethical consequences. Why? Because geo-historical and bio-graphic (constructed, of course, in the same way that zero point epistemology is constructed) loci of enunciation have been located by and through the making and transformation of the colonial matrix of power: a racial system of social classification that invented Occidentalism (e.g., Indias Occidentales; that created the conditions for Orientalism; that distinguished the South of Europe from its center (Hegel); and that remapped the world in First, Second, and Third ranking during the Cold War. (Darker Side 119)

In this regard, the letter inserts modern urban industrial imagery - bodies, spaces, machinery - into a new web of meaning and body of knowledge. The delinking called for by Mignolo is undertaken, for instance, at a micro level, through a reformulated relationship between signifier and signified.

The automobile, for instance, the commodity par excellence of industrial modernity, is described as a 'carruage[m] de prata, forrada de pele finíssima' ['silver caravan lined with the finest furs'] (106). The realm of objects as they reside within a capitalist sphere of production is narrativized by Macunaíma in a manner that ambivalently eludes the bourgeois abstraction of each object's use-value, from which exchange value emerges. This sort of re-narrativization, or de-narrativization, 'engag[es] in epistemic disobedience and delinking from the magic of the Western idea of modernity' (Mignolo, Darker Side 120).

Macunaíma's re-narrativizing of the realm of production and the circulation of commodities essentially strips these (commodities) of their magic - their exchange value, that which permits the performance of bourgeois identity, especially in relation to the marginalized and othered proletariat. Macunaíma's account of the modern urban realm of power tacitly ties the abstraction of value regarding commodities (including labor) to the performance of identity at different ends of the spectrum of power. 
In the space of three paragraphs, he is able to connect, without overtly Marxian language, the exploitation of immigrant labor, the production of commodities, ownership over the modes of production, performance of bourgeois life as tied to the commodity, and political power. This is the imperial trajectory of production to consumption. After all, Antropofagia is as much about the formation of a decolonial site of postcolonial consumption as it is about critiquing dominant forms of consumption.

Dominant consumption in the postcolony is, of course, inextricably linked to a national elite consolidated through Western modes of production and performed by way of European forms of bourgeois cultural identity. Bourgeois identity is then predicated on the abstraction of value ascribed to commodities; one divorced from the value of labor. The value of the commodity is subsequently expressed by its consumed existence as an appendage to the body. The bourgeois postcolonial subject, which is antithetical to Antropofagia, is ultimately an amalgam of commodities that originate from the industrial space of labor - namely the confines of the factory in Macunaíma's letter.

Macunaíma's writing on the city subtly presents the realm of production (and consumption) and wealth accumulation as a vicious cycle. São Paulo's industrial elites engender the conditions for surplus labor as the construction of factories drives internal migration and foreign immigration to the city. Through a constant labor surplus, the 'milionários' consolidate their control over the means of production. Ensnared by the controlled means of production, the surplus labor embodied by Italian immigrants ('italianinhos') resides on the outskirts of the city - the exponentially growing 'bairros miseráveis' (106). While the socioeconomic critique within the novel is not as fleshed out and nuanced as the Marxist-influenced readings of History offered by Oswald de Andrade's poetry and political writings, Macunaíma's letter nonetheless ties together various elements of modern urban power and how such power informs identity across this spectrum. The means of production and wealth accumulation, colonial processes of industrial capitalism, also inform the layout of the city, the paradoxical overlapping of spaces of production, subalternity, and privilege; Macunaíma points this out referring to the physical proximity between the twelve thousand factories and largest cafés in the world.

The term café is likely deployed as a double entendre. Firstly, it signifies a space of privileged consumption-as-performance embodying the bourgeois usurpation of the public sphere (see Habermas). At a deeper layer, it genealogically points toward the historical accumulation of wealth and power by São Paulo elites. The booming coffee industry of the nineteenth century led to the concentration of wealth in the state of São Paulo, where 
the largest portion of the industry was located. By 1840, coffee accounted for $43.8 \%$ of Brazil's total exports (Bethell 85 ) reaching $63.9 \%$ in 1950 before its decline due to the emergence of other exports (see Fausto). The accumulation of wealth derived from coffee production gave rise to state elites that would eventually dominate the national political sphere. This predictable intersection of wealth and political power reached its apex during Brazil's First Republic (1889-1930) - a historical period of national politics, the tail end of which witnessed the rise of the anthropophagic modernist movement. This geographical concentration of power famously became known as 'café com leite' ['coffee with milk'] politics in reference to São Paulo's coffee production and Minas Gerais's dairy industry. All of the First Republic's presidents came from these two states. Subsequently, the concentration of political influence led to consistent satisfaction of the political interests and demands of these two states and their respective elites, reproducing their wealth and population/labor force. From the wealth and political power accumulated by way of the coffee industry, the city of São Paulo, the state's capital, became the core of Brazil's industrialization founded on Fordist methods of factory production.

From the concentration of wealth and political power emerge the conditions for brutal industrial - that is, modernized - forms of exploitation. While the transition from a national monarchy to a republic, along with the abolition of slavery, were narrativized as national modernization projects, they did not displace the imperial field of meaning where national power is narrativized. As I have argued elsewhere (Silva, Subjectivity), the modernization of the nation became, at its core, the reconsolidation of imperial forms of power and wealth concentration through reformulated modes of otherness, brought on by overlapping discourses of industrialization, urban renewal, and eugenics. At the heart of this reproduction of Empire and reconsolidation of its material conditions was the same imperial scene of writing against which Antropofagia, despite pitfalls, positioned its project.

\section{Reversing Empire's Psychic Links}

The strangeness with which Macunaíma consumes this paradoxical overlapping of spaces of production, subalternity, and privilege of the urban terrain - understanding it as a paradox - performs a crucial sort of delinking. He fails to misrecognize the inner workings of the imperial symbolic order of the industrial city. As a writer/consumer who has not been interpellated into the city's field of meaning, thus not possessing an identity/ place within production, Macunaíma is not taught how to read or link the field's circulating signifiers. The imperial field of meaning is, moreover, an 
economy of desire where interpellation is the successful synchronization of the subject's desire with imperial power's desire for reproduction. Louis Althusser famously extrapolates interpellation from Jacques Lacan's mirror stage where the uninterpellated individual - embodied by the trope of the infant - confronts the image of their ideal identity - ideal for power's field of meaning. The formation of this image - the ideal ego - is thus narrativized trans-temporally through the desire of the symbolic order, the Lacanian big Other. The ideal ego is what the big Other wants from the subject at the moment of interpellation. Interpellation is never one isolated moment, but a constant process of regulating the subject's desire in agreement with the desire of the Other, in this case, Empire. Lacan notably attributed this regulation to the paternal function within the patriarchal organization of society, but it is not limited to the gendered role of the father, biological or otherwise. Part of the interpellation, the social agreement between subject and Other, is that the interpellated individual will go on to become a scene of writing for the Other, a producer of meaning that will reconsolidate and reproduce the Other as a field of meaning.

In Macunaíma's journey from the forest, the space of precolonial fantasy, to the space formed by industrial production and massive imperial manipulation, he enters the latter physically but is never ideologically inserted into it through power's subjectivation. The interpellated subject would be firstly, in Mignolo's words, the object of knowledge, akin to the ideal ego as the strategic agglomeration of meaning that forms imperialized identities and scenes of writing. If the interpellated subject is the discursive intersection between object of knowledge and subject of knowledge, Macunaíma, as constructed by Mário de Andrade, is a pure subject of knowledge. Andrade's aesthetic and political project of embodying the cannibal metaphor perhaps inevitably forms an entity that is a pure scene of writing. In this regard, Macunaíma's lack of character or personality plays into this aspect of Andrade's version of the anthropophagic project. As someone with little awareness of proper interpersonal conduct, he seemingly comes from no symbolic order from which a subject can be expelled for not following implied intersubjective laws.

As he weaves through various cultural and epistemological realms, he reads different components of Empire's signifying field (such as capitalist modes of production) without misrecognizing them, in the Marxist sense especially the most perilous of them that he encounters in the city. If he truly ever becomes an object of knowledge, it is through being first and foremost a subject of knowledge; that is, through the meanings which he consumes, collects, delinks, and reformulates throughout his journey. In this regard, Mário de Andrade reverses the imperial order of subjectivation through 
Macunaíma. The path toward decoloniality in the novel begins through a scene of writing that is not merely an object of imperial knowledge, but is firstly a critical reader and writer of meaning.

If the scene of national writing culturally and socioeconomically located in the bourgeois locales of the city is one that is successfully interpellated into the imperial field of meaning, the anthropophagic scene of writing must be somehow uninterpellated. The imperial subject/scene of writing, embodied in the letter by the São Paulo industrial capitalist, ultimately represents the intersection of Empire's desire with that of the subject; the bond of desire necessary for the reproduction of power. In desiring the accumulation of wealth via the oppressive mechanisms of production, the capitalist subject also desires - and reproduces - the field of meaning that designates the bodies to be marginalized, based on imperial taxonomies of race and transnational flows of capital and people. The industrial city, in this case São Paulo, is part of a global web of production, consumption, and markets. Its factories are staffed by the descendants of African slaves - the primordial globally translocated labor force - as well as European peasants and proletariats, subalternized in their own national economic contexts. The search for survival of what can be considered a global subaltern class emerging from Empire ultimately leads to the population and formation of the world's mega-cities, the global capitals of production. The influx of European workers into São Paulo, and many other cities of the Americas, was further propelled by state-driven whitening initiatives. In this regard, eugenic discourses and ideals of national improvement based on imperial notions of white superiority, backed by pseudo-science, further drive the slumization of the city. The presence of italianinhos in the São Paulo periphery is ultimately the product of the multi-localized desire of Empire. The reproduction of inequities in Italy guided by the hyper-concentration of wealth intersects with the reproduction of inequities in Brazil led by the desire for wealth accumulation in the industrialized postcolony. Both desires, in their own distinct, yet overlapping locations, are, of course, sanctioned by the imperial field of meaning.

Within this realm of inequities and classification of bodies and life, bourgeois identity is performed - itself a reproduction of Empire. The industrial elite subject, including the President Macunaíma witnesses cruising through São Paulo (106), reads the field of meaning - crystallized by the ideal ego in the mirror stage - at the moment of interpellation. In this regard, Macunaíma does not fail to point out the close relationship between the wealthy industrial class and the realm of municipal and national politics. The subject's desire within Empire thus operates in agreement with the white patriarchal capitalist structuring of power, 
as underscored by his quotidian actions. Economic luxury in terms of consumption of objects and a performance of hyper-masculinity embodied by polygamy constitute the performance of identity as the reproduction of power.

From his uninterpellated place, Macumaíma re-historicizes the phenomena he encounters in the city, thus enunciating a new narrative of urban life divorced from the power relations that mark the existing narrative. In this regard, Macunaíma's letter on São Paulo offers an interesting dialogue with Mário de Andrade's earlier collection of poems on the city, Paulicéia Desvairada [Hallucinated City], in which urban life is reimagined through the lens of urban industrial apocalypse, articulating the city as a locus of abjection and death. The city is thus a terrain of Western and industrial power that mutilates the landscape and the bodies that populate it through production and labor exploitation.

\section{Logocentrism and Antropofagia's Failure}

The very writing of the letter, the logocentric act itself and the speech through which Macunaíma conveys the urban field of meaning, carries its own complexities. Through his act of writing, he takes up the logocentric mode of Western signification while simultaneously critiquing it. Macunaíma writes using archaic European Portuguese vocabulary and syntax only to then underscore the chasm between spoken and written Portuguese, particularly when describing the people of industrialized and socially compartmentalized São Paulo. Of São Paulo's elites, he writes 'ora sabereis que a sua riqueza de expressão intelectual é tão prodigiosa, que falam numa língua e escrevem noutra' ['now you shall know that their rich intellectual expression is so prodigious that they speak in one language and write in another'] (106). In articulating such a discrepancy, he gives postcolonial primacy to phonocentrism by parodying logocentrism - and bourgeois linguistic production - and explicitly aligning it with European colonial endeavor and the Latinization of the New World.

He thus ties the logocentric incarnation of the language to the performance of white bourgeois power in the postcolony. In mimicking bourgeois writing, he ultimately mimics bourgeois identity, particularly in its enunciation of otherness - in this case the othering of spoken Portuguese in Brazil:

Mas si de tal desprezível língua se utilizam na conversação os naturais desta terra, logo que tomam da pena, se despojam de tanta asperidade e surge o Homem Latino, de Lineu, exprimindo-se numa outra linguagem, mui próxima da vergiliana, no dizer dum panegirista, 
meigo idioma, que, com imperecível galhardia, se intitula: língua de Camóes! (107)

[If such a despicable language is used in conversation by the natives of this land, as soon as they take up the pen, they abandon such coarseness and there emerges the Latin Man, of Linnaeus, expressing themselves in another language, much closer to that of Virgil, in the speech of a panegyrist, gentle language that, with imperishable gallantry, is called the language of Camóes!]

Aside from transforming the protagonist into a narrational voice or an internal anthropophagist, the 'Letter to the Icamiabas' offers a stark contrast to the linguistic project carried out by the novel's narration. In this regard, the integration of the letter in the novel performs a parodic articulation of difference; a difference that is now located among European language and linguistic production. Within the novel's own system of meanings, this mode of language is to be read as other; thus tentatively effacing the linguistic prestige of this temporally situated and historically produced variant.

As Mignolo reminds us, 'Modern European languages embodied, during and after the Renaissance, the 'spirit' of epistemology' (Darker Side 183). It is perhaps no coincidence then that the letter reproduces the prose of renaissance Portuguese travel writers. The starkest example of this would be the use of what today is the second-person plural subject pronoun vós (and conjugations) as a hyper-formal second-person singular address, often reserved for royalty. Antropofagia had, of course, a well-delineated mission regarding language, which was 'to Brazilianize the Portuguese language, rejecting archaisms and erudition while proclaiming the naturalness of neological forms, which should come into everyday usage from contact with languages such as Tupy-Guarani and Yoruba' (Jackson 100-01). The language of the novel (excluding the letter) embodies this aspect of the anthropophagist project. It becomes a text, a series of meanings and signs, which is to be consumed and reformulated from the manipulated and marginalized signifiers of colonial otherness. From there, the cannibalized language-text is also to be the mode through which the negotiated anthropophagist scene of writing shall decolonize the nation-sign.

The use of a highly Europeanized writing, itself a collection of linguistic signs, to critique imperial narrativization serves as a useful metaphor for the avant-gardist uses of European forms, the main limitation being that such cultural movements of anti-imperial political stances emerge from sites of relative social privilege. The movement openly aimed to distinguish itself 
from the bourgeois cultural production of the time, although its members were, as Jean Franco notes, 'sophisticated urbanites' (94). Esther Gabara offers a thorough review of the critiques levied against early twentiethcentury modernisms in Latin America, including Antropofagia:

scholars such as Natalia Majluf and Sérgio Luiz Prado Bellei, as well as George Yúdice and Roberto Reis take this generation of writers and artists to task for their participation in a nationalist ideology that depended upon primitivist attitudes toward the native and black populations in the Americas. They examine how this generation of thinkers, including Peruvian José Carlos Mariátegui, Cuban Renato Ortiz, and Mexican José Vasconcelos, produced theories of transculturation and mestizaje (racial mixture) from the position of the same social elites who had controlled power and wealth in the region since independence. Prado Bellei's conclusion that modernism provides little 'emancipatory potential' is typical of contemporary reactions against the heroic proclamations of the 1920 s and 1930s. (63)

The larger critique of the movement would thus assert that, in many ways, it reproduced what it purportedly repudiated, especially due to its own use of European aesthetic trends. Mário de Andrade points out as much in his reflection on Brazilian modernism on the twentieth anniversary of São Paulo's modern art week. In his essay, 'O Movimento Modernista,' Andrade recalls the movement's 'revolta contra a intelligensia nacional' ['revolt against the national intelligentsia'], while also underscoring that the 'modas que revestiram este espírito foram diretamente importadas da Europa' ['styles that conveyed this spirit were imported directly from Europe'] (non. pag.), alluding here to the European modernisms that emerged from the cultural aftermath of World War I. Andrade also denounces the group's brand of modernism: 'o movimento renovador era nitidamente aristocrático. Pelo seu caráter de jogo arriscado, pelo seu espírito aventureiro, pelo seu internacionalismo modernista, pelo seu nacionalismo embravecido, pela gratuidade antipopular, era uma aristocracia do espírito' ['this renovating movement was clearly aristocratic. Due to its risky character, its adventurous spirit, its modernist internationalism, its infuriated nationalism, its anti-popular gratuitousness, it was an aristocracy of the spirit'] (non. pag.).

For Mário de Andrade, therefore, the movement's ultimate downfall was due not only to its bourgeois origins, but its subsequent inability to engender a cultural discourse that could surpass its origins. This would have implied a scene of writing that could fully eclipse the subject-position from which it was spawned. The construction of a decolonial place of 
signification never usurped the very colonial (in the sense of coloniality) place that birthed the movement. To put it in Andrade's own words, the anthropophagus never erased, or at least divorced itself from, the aristocracy of the movement's spirit. We can thus read the prose of Macunaíma's 'Letter to the Icamiabas' as perhaps an expression of Mário de Andrade's internal critique of the movement. The letter's scene of writing, despite its spirit of renovation and impulse to modernize the production of national meaning from a decolonial site, cannot help but speak from a lexicon of colonial privilege.

This perhaps points to a greater antagonism within the novel, as Mário de Andrade constructed it, pitting the prose of the 'Letter to the Icamiabas' against that of the rest of the novel. Whereas the latter embodies a gesture toward a decolonial langue for the postcolony, the prose of the letter within and vis-à-vis the novel embodies colonial continuity, that which is most difficult to vanquish as it resides in the power (inherent to the system) of those who articulate change. Amílcar Cabral notably called this necessary step, the most obstinate one on the road to anti-colonial revolution, 'class suicide' - the postcolonial bourgeoisie's foregoing of its own interests in favor of those of the subaltern (110). The next - unfulfilled - phase in the Antropofagia project was perhaps this transition, implying a sustained shift in enunciatory locale, from the urban cultural aristocracy to the subject-positions that reside at the margins of the imperial field of meaning that informs the nation-sign. The failure of the movement, however, does not irrevocably tarnish its objective. Despite the seemingly irreconcilable discrepancy between the anthropophagic scene of writing and the scene of writing from which the movement emerges, Antropofagia 'may nevertheless put into question the authority of Europe's "long story" of modernity" (Madureira 23), and 'nonetheless evokes, if only inchoately, the terror of totalizing projects' (Madureira 50).

\section{Reading the Realm of Concepts, Interrupting Interpellation}

Part of Antropofagia's decolonial project meant grappling with and contesting the role of modern global capitalism as well as the larger international colonial matrix of economic dependency and imperial epistemology. The formation of international relationships of economic dependency was, for Oswald de Andrade, tied to the reproduction of this imperial field of meaning. He has tacitly connected it to the European philosophical tradition of rationalism. This relationship between Reason and Empire would be famously interrogated in greater depth by Michael Hardt and Antonio Negri in Empire, where they trace contemporary hegemony within global capital 
back to Reason's suppression of immanence as the philosophical ground upon which 'modern sovereignty' emerged. As opposed to immanence, embodied by Spinozan ethics, Reason implied a grip on how individuals related to the material world, a hold on meaning in other words. As a consequence of Reason's mediated reality, 'Nature and experience are unrecognizable except through the filter of phenomena; human knowledge cannot be achieved except through the reflection of the intellect; and the ethical world is incommunicable except through the schematism of reason' (Hardt and Negri 78-79; emphasis original).

Antropofagia, therefore, implies perhaps not a return to immanence, but at least a critique of Kantian transcendental philosophy that offered a fleshed-out philosophical foundation for imperial epistemology, namely the positing of knowledge as transcendental: knowledge that 'is occupied not so much with objects, as with our a priori concepts of objects (Kant, Basic 38). Through the transcendental model of knowledge, the consumption of colonial otherness is made possible - knowledge without experience. More precisely, the transcendental implies the precedence of the concepts of objects over the experience of them. In other words, imperial knowledge pertaining to bodies, geographies, and commodities becomes the frame through which these entities are experienced. The interpellation of the subject into the imperial field of meaning is ultimately the formation of a transcendental - in a strictly Kantian sense - subject, one whose experience of objects is grounded in the shifting definitions of them as they have been narrativized. This is, for Kant, the basis of Reason - 'the faculty which supplies the principles of knowledge a priori' (38). Reason, therefore, not only offers the ideological grounds for global forms of domination through logics of legitimization, it is the modus operandi of subjectivity as it resides within global power's web of meanings.

Mignolo interestingly points out Kant's own moments of consumption when discussing the latter's take on geography: 'The global totality that Kant searches for in his Geography, which parallels other fields of his inquiry, is driven by an anxious will to control knowledge and a blind sensitivity toward what he overrules by means of what he appropriates' (Darker Side 182). More than merely a totality, it firmly reproduces existing imperial modes of power and categories pertaining to race, gender, and sexuality. In his Anthropology from a Pragmatic Point of View, a compilation of material he had taught on the subject for 25 years, Kant notably constructs a binary realm of gender difference through what he called 'nature's economy.' Gender difference is thus a product of natural forces, interests, and nature's division of labor. Eduardo Mendieta and Stuart Elden succinctly capture Kant's conceptualization of man and woman: 
Nature's economy, according to Kant, has entrusted to woman's womb the 'dearest pledge, namely the species.' It is for this reason that nature has implanted in woman fear of physical injury and in particular of sexual injury. By the same token, this fear has given rise to female timidity. And for this reason, woman must rightly claim the protection of the male. Woman's role as the preserver of the species requires a protector of the womb of the species. (356)

Kant, therefore, not only offers the theoretical blueprint for knowledge with his theses on reason, but also enacts his argument of transcendental knowledge in his historicization of the world.

Kant is firmly embedded in Empire's field of meaning and is thus another scene of writing for its reproduction. His interpretation of racial and geographic difference in Physical Geography is based on an existing set of concepts pertaining to bodies and spaces, one that narrativizes particular racial hierarchies. He notably theorizes human perfection in terms of skin color and climate:

In the torrid zones, humans mature more quickly in all aspects than in the temperate zones, but they fail to reach the same degree of perfection. Humanity has its highest degree of perfection in the white race. The yellow Indians have a somewhat lesser talent. The Negroes are much lower, and lowest of all is part of the American races. (316)

Kant succinctly narrativizes power in racialized terms, proclaiming difference as a natural truth. The epistemological consequences of doing so, moreover, delineate a particular path of History, a field of meaning that is monological and dominated by the whiteness.

Displacing Reason altogether is perhaps beyond the philosophical scope of the anthropophagist project. The political end, however, may lie in recircuiting the transcendental basis of knowledge toward the objective of enunciating a decolonial scene of writing/consumption. The issue with the transcendental is not the philosophy itself, but the political purposes it serves, namely the narrativization of global and intercultural time and space, in conjunction with the political and economic power of Europe. We can already perceive this relationship between the transcendental and Western imperialism in the writings of Kant himself.

The project of delinking thus aims for a reordering of the 'concepts of objects.' Over a century after Kant, Ferdinand de Saussure would schematize more precisely what the concept of an object meant. Saussure, of course, called the constellation of concepts langue - a system of signs, themselves constituted by the relationship between signifier and signified, while 
the object itself remains outside of the relationship. Knowledge, in its transcendental form, as it is a product of concepts and not objects, can therefore be thought of as pure narrativization. This is precisely Hélène Cixous and Catherine Clément's theoretical argument when exploring European constructions of otherness at the moment of encounter as the formation of a sign that forecloses the native's subjectivity:

What is the 'Other'? If it is truly the 'other', there is nothing to say; it cannot be theorized. The 'other' escapes me. It is elsewhere, outside: absolutely other. It doesn't settle down. But in History, of course, what is called 'other' is an alterity that does settle down, that falls into the dialectical circle. It is the other in a hierarchically organized relationship in which the same is what rules, names, defines, and assigns 'its' other. With the dreadful simplicity that orders the movement Hegel erected as a system, society trots along before my eyes reproducing to perfection the mechanism of the death struggle: the reduction of a 'person' to a 'nobody' to the position of 'other' - the inexorable plot of racism. (70-71)

It is thus the imperial writing of the concept that forecloses the person. The other becomes knowable only as the other, a text, never as the person. In purely Kantian terms, then, the concept of the object erases the object, and the field of meaning in which power resides and is reproduced is based solely on the concept as it is articulated by power.

The anthropophagic mission is not to articulate a longing for a pre-transcendental epistemological form, however. The anthropophagic scene of writing, like that of Macunaíma in his letter, aims to shift the concept (of bodies, nation, etc.) as it is read in the postcolony. The rearticulation of concepts would ultimately foment emergent decolonial scenes of writing from which the Brazilian nation-sign, as well as the subjects residing therein, can be disentangled from the Eurocentric field of meaning. This would usher in, through the possibility of a decolonial subject, a shift in political power, one that may articulate the nation through the spectrum of voices that inhabit its geopolitical borders. The overarching objective would thus be political change through a shift in the subject. As Félix Guattari argues with regard to the production of subjectivity, 'the various semiotic registers that combine to engender subjectivity do not maintain obligatory hierarchical relations fixed for all time' (1). The interpellation of the subject is never a seamless operation. Rather, the moment in which the individual is hailed, thus confronting the ideal ego, is fraught with tension and uncertainty. The individual may not respond to power's desire being conveyed through the image. Interpellation is thus a consistently repeated 
process - a pedagogical operation that teaches how to desire. Nonetheless, in the interstices of these repeated moments conveyed through 'various semiotic registers' (Guattari 1) - economic, cultural, racial, gender - the concentration of power may not change though its signifiers are in flux, and new meanings may emerge.

It is here that Antropofagia intervenes - in the dispersed moments of subjectivation, presenting a new mode of reading the field of meaning into which the subject is interpellated. Part of the ideal ego, as an image of productivity for the desire of the big Other, is its ability to produce meaning - its promise of becoming a scene of writing. The anthropophagic project thus sets in motion a revising of the subject starting with its production of meaning as the central facet of subjective performativity. The shift in the subject, in other words, must begin somewhat retroactively, or in a possibly opposite order. This is not to argue that the Althusserian hailing and the production of meaning are temporally separate phenomena. I would argue, rather, that they are part of the same agreement. In Mário de Andrade's focus on the subject's production of meaning, we understand that the subject cannot adequately respond to the big Other's desire without the hailing. On the other hand, a hailed subject is rendered useless to the Other if it does not perform its identity in agreement with the tenets of Empire. This seems to be the logic that undergirds the deployment of the cannibal metaphor in Macunaima. The text cannot fully intercept the hailing, especially because it cannot erase the imperial field of meaning; nor does it intend to, but it can impact the other deeply intertwined part of the equation - the interpellated subject's production of meaning.

The novel - and, ironically, its uninterpellated protagonist - is thus directed toward the interpellated reader, the subject residing within the global imperial field of meaning, particularly that residing and circulating among the nation's privileged circles and/or literati. The objective then becomes to connect the imperial reader to the uninterpellated scene of writing that is the novel's titular character. Macunaíma, within the novel's diegetic realm, is not taught to desire Empire. He is thus outside of desire, and his own desire is only liminally found in the imperial field of meaning as it is produced by Mário de Andrade from his own reading of History. In the reader's realm of meaning, Macunaíma is an amalgam of imperial signifiers, a product of Empire's historicization. At the same time, Macunaíma is also the uninterpellated reader/translator of the field of meaning in which the book's reader resides.

Mário de Andrade does not merely create Macunaíma's scene of writing, he does so with the overarching goal of dictating a relationship between it and the postcolonial reader. This would be a connection between uninterpellated 
internal reader and implied external reader. The 'Letter to the Icamiabas' represents the most significant attempt at this. In the letter, the imperially interpellated reader must read the realm of objects as a text produced by the uninterpellated scene of writing. The reader must first understand Macunaíma precisely as uninterpellated in order to grasp his epistemic disconnection from the imperial realm of concepts. Only through this process can the novel successfully offer a model for decolonial rereading and delinking. In doing so, the text of History can be re-evaluated and the subject's place within it critiqued. From here, the rewriting of the field of meaning can begin, and perhaps only then can a decolonial, or 'Brazilian,' Brazil begin to be articulated.

Reading Macunaima from a dialectical materialist approach, one can thus argue that subjective - national - change must come first from a shift in the production of meaning. The novel, and the larger Antropofagia movement, seems to separate subjectivation into two simultaneously emerging parts: interpellation (hailing) and writing (the production of meaning). Rather than challenging interpellation directly, the cannibal metaphor and its focus on writing (reading/consuming and producing/the end of the digestion process) implies a theory of ideology and ideological change that gives precedence to the production of meaning. In other words, the emergence of a decolonial subjectivation must begin with the production of meaning that intervenes in the imperial signifying field from which interpellation takes place. It is from such a shift that decolonial interpellations may then occur and reproduce each other, subsequently resignifying the nation-sign of Brazil, and the larger field of meaning in which it is couched.

In more racial terms, the goal of Antropofagia (at least for Mário and Oswald de Andrade) was in many ways to decenter whiteness as the privileged scene of national writing. In starting with signification/ consumption, the anthropaphagus intervenes against the end result of white identity and performance, the reproduction of the imperial signifying chain, both national and global. The objective was to produce national and transnational meanings pertaining to bodies and capital in a way that is divorced from the racially privileged subject-positions that national writing has reproduced. In doing so, the anthropophagists complicate the notion at the heart of Western power that there is only one linear History, the narrative of Western hegemony, which is told by the West and props up its power. 


\section{From Modernism to Multicultural Fascism}

From the vantage point of the present, one can perhaps argue that the anthropophagic movement, although short-lived, was somewhat successful in engendering new, decolonial, modes of consuming the imperial field of meaning. The cannibal metaphor, though, also led to consumptions and resignifications that were less than decolonial. Although there emerged new modes of national multiculturalism and multiracial nationalism from Antropofagia, these narratives did little or nothing to efface the racial and sexual modes of power, and became, moreover, apparatuses for reproducing a white heteronormative bourgeois patriarchal society. Equally notable were the political shifts that emerged on the heels of the movement. Mário de Andrade later reflected that: 'o movimento de Inteligência que representamos, em sua fase "modernista” não foi o gerador das mudanças político-sociais posteriores a ele no Brasil. Foi essencialmente um preparador, o criador de um estado de espírito revolucionário' ['The movement of the Intelligentsia that we represented, in its "modernist" phase did not generate later sociopolitical shifts in Brazil. It essentially prepared, or created a state of revolutionary spirit'] ('O Movimento' non. pag.). As Walter Benjamin's famous axiom warns, though, 'the rise of fascism bears witness to a failed revolution' (cited in Žižek, Living 152). One can argue that this was the case in post-modernismo Brazil.

The year 1930 brought an end to the café com leite politics of the First Republic, thanks to a military coup d'état born of dissatisfaction among the larger national bourgeoisie and the military. The impact of the Great Depression ultimately spelled the end of the political control of São Paulo/ Minas Gerais. This was an interstate relationship that had already been compromised by São Paulo's support of its state president Júlio Prestes for president of Brazil. The coup ousted the president-elect, Prestes, and the incumbent president, Washington Luís, on October 24, 1930. As a consequence, Getúlio Vargas from the state of Rio Grande do Sul, the runner-up in the presidential election won by Prestes, was named president. In the process, the constitution of the First Republic was repealed, and Vargas was handed broad political powers, essentially ruling by decree. The situation worsened further when Vargas circumvented national restrictions on re-elections by declaring a state of siege in response to a supposed planned communist revolution. This ultimately gave birth to the corporatist authoritarian regime known as the Estado Novo in November of 1937.

Aside from stifling proletarian organization and imprisoning dissenters of his brand of fascism, Vargas's regime also looked to construct a multiracial vision of Brazilianness. This was undoubtedly part of his populist rhetoric 
and went hand in hand with his economic policies of state intervention, especially in terms of the working class, a climate in which organized labor was articulated as anti-national. As Alexander Edmonds reminds us, 'when Vargas addressed the "workers of Brazil" by radio, he was expressing a particular vision of the body politic. Labor was reimagined as the essence of working-class citizenship' (112). Part of Vargas's propaganda machine was, as Colin Maclachlan notes, the stimulation of 'a useful sense of nationalism. Radio loudspeakers placed in central locations by the government made sure people got the message. Propaganda stressed that all had something to offer their country, whether poor or rich, without reference to race' (103). As Maclachlan succinctly puts it: 'The Estado Novo rested on three main pillars - the army, bureaucracy, and urban workers - while propaganda smoothed over any contradictions' (103).

In many ways, the Estado Novo co-opted the anthropophagic project of building a Brazilian-Brazil, but one that served Vargas's political agenda, namely the reproduction of a small sphere of power and control over the nation's proletariat and sub-proletariat. It was, of course, the Vargas regime, both under the Estado Novo and during his later democratically elected presidency (1951-54), which promoted a multiracial brand of popular culture to embody the nation, thus propelling his form of populism. For instance, Vargas played a major role in the establishment of samba - a musical genre of Afro-Brazilian origins - as an official Brazilian cultural expression, and Carnival as a national event. He offered official and economic support for samba schools, subsidizing such institutions throughout Brazil. In addition to the participation of samba schools in Carnival celebrations, he called for strictly 'national' floats to appear during Carnival parades, thus barring non-Brazilian cultural symbols. In terms of Afro-Brazilian representations during Carnival, satirical racist floats were banned in favor of those that evoked African contributions to the brand of national identity the Estado Novo sought to portray.

It was also under the Estado Novo that soccer became a central part of post-Antropofagia Brazilianness; the sport becoming another medium through which to convey a multiracial nation where all participate:

Similar to what he had done with samba and Carnival, Vargas sought to use soccer as a way of unifying the nation, creating a common source of identity, and developing a single national culture. And as had happened with samba, this meant discrediting the racist notions that kept black and mulatto Brazilian players from competing widely. (Meade 204)

The Estado Novo's official investment in soccer as national pastime ultimately served as a blueprint for the later right-wing military dictatorship (1964-85) to perpetuate the false narrative of racial inclusivity. 
This was, and continues to be, a narrative that reproduces imperial power rather than displacing it. While the regime looked to carve a space for black history within the nation-sign of Brazil, it also suppressed the Frente Negra Brasileira [Black Brazilian Front], for instance. Considered a political party by the Estado Novo, the Frente was declared illegal and suffered the same fate as other parties, all outlawed by Vargas. In terms of blackness in Brazil, and negotiation of the nation-sign, the Estado Novo sought to impose a strict distinction between culture and politics. The limiting of representations of blackness to samba, carnival, and soccer - the realm of entertainment - produced a signification of Afro-Brazilianness and Afro-Brazilian bodies that excluded these from political action and participation. Blackness was to be known nationally through the comfortable signifiers of music and sport, divorced from the political sphere; cultural meanings that made the nation knowable to its population. The Estado Novo thus articulated its own version of a Brazilian-Brazil while barring most Brazilians from the anthropophagic dream, a perpetually undefined scene of writing that called for the Brazilian-Brazil to be an open-ended sign. Rather, the Estado Novo and later military dictatorship co-opted the project by essentially usurping the scene of writing to construct a multiracial narrative that obfuscated its monologic imperial core.

The Estado Novo was not the only right-wing political entity whose emergence can be tied to Antropofagia and Brazilian Modernismo. The fascist movement known as Integralismo [Brazilian Integralism] was notably spawned by a member of the modernist cultural circle: Plínio Salgado, a writer and journalist from the state of São Paulo. While working as a journalist with the Republican Party of São Paulo, he became friends with César Menotti del Picchia, one of the Grupo de Cinco - five of the most emblematic members of the Modernismo movement alongside Tarsila do Amaral, Anitta Malfatti, Oswald de Andrade, and Mário de Andrade. Salgado went on to launch the right-wing nationalistic Verde-Amarelismo [Green Yellowism] movement, alongside del Picchia and other modernist participants, poet and literary critic Cassiano Ricardo, and essayist Cândido Mota Filho. The group itself, like its writings, was a polemical response to Oswald de Andrade's Brazilwood Manifesto and Antropofagia in general. Raul Bopp, a poet and one of the more acclaimed members of the Brazilian modernist movement, joined the nationalistic group. Salgado and Bopp co-founded the Escola Anta [Tapir School] - a more left-leaning section of the Verde-Amarelo movement - in 1927, before Salgado started the fascist Integralist party.

Salgado's nationalistic discourse was centered on the Anta, as Madureira notes from the Verde-Amarelo manifesto, co-authored by Salgado, Menotti del Picchia, and Ricardo: 
the authentic meaning of Brazil's national character is said to reside in the unyielding and savage will of the Anta people, as expressed in their precolonial descent into the Atlantic coast from the continental plateau [...] advancing inexorably, with tapir-like single-mindedness, across the Amazon, finally to expel the shore-dwelling Tapuias - posited as the symbol of national origin. (Madureira 30)

While Mário and Oswald de Andrade sought a postcolonial project embodied by the anthropaphagus, the cannibal metaphor, Salgado and the verde-amarelistas preferred the tapir metaphor to convey a Brazilian origin untouched by colonialism. They thus located this figure away from the coast where European settlement and postcolonial wealth was concentrated and, by extension, where the nation-sign was negotiated by Eurocentric elites.

The Verde-Amarelo manifesto thus narrates the cultural antagonism within the nation-sign as a historical conflict between Eurocentric and indigenous groups, modern and precolonial. The manifesto explicitly renders the tapir of the continental plateaus and the Amazon as the Tupi people, positing them as the embodiment of Brazilian origins. The anta is, according to the manifesto, 'um animal que abre caminhos, e aí parece estar indicada a predestinação da gente tupi' ['an animal that opens trails, and there resides the predestination of the Tupi people'] (Salgado, Menotti del Picchia, and Ricardo non. pag.). In this way, the movement called for 'an intensive study of Tupi language' (Madureira 30) as the system of linguistic/ semiological differences through which Brazil could truly become Brazilian.

The manifesto begins by proclaiming that 'a descida dos tupis do planalto continental no rumo do Atlântico foi uma fatalidade histórica pré-cabralina, que preparou o ambiente para as entradas no sertáo pelos aventureiros brancos desbravadores do oceano' ['the descent of the Tupis from the continental plateau toward the Atlantic was a pre-Cabraline fatality that prepared the conditions for entry into the sertão (backlands) by white adventurers, explorers of the ocean'] (Salgado et al. non. pag.). The Tupis, in their mythic construction, serve as the antithesis of the Tapuia: 'o tupi significa a ausência de preconceitos. $O$ tapuia é o próprio preconceito em fuga para o sertão' [the Tupi means the absence of prejudice. The Tapuia is prejudice itself fleeing into the backlands'] (Salgado et al. non. pag.).

The Tapuia is, in other words, the condensation of European-imposed forms - knowledge, religion, art, and, perhaps more importantly, the corruption of the Tupi 'original.' In the scheme of the nation-sign, 'todas as formas do jacobinismo na América são tapuias. $O$ nacionalismo sadio, de grande finalidade histórica, de predestinação humana, esse é forçosamente tupi' ['all forms of Jacobinism in America are Tapuia. Sound nationalism, with a great 
historical objective, of human predestination, is perforce Tupi'] (Salgado et al. non. pag.). Prior to evolving into Salgado's Integralism, the Verde-Amarelo project laid much of the cultural and philosophical groundwork for the fascist conception of the nation, namely a very fixed teleology: the predestined purpose of the Tupi people is to be the symbolic driving force for the nation, leading it to be the next great civilization, the 'fifth race' that will become the universal form of humanity. Citing and supporting the work of Mexican intellectual José Vasconcelos, Salgado affirms that

é de entre as bacias do Amazonas e do Prata que sairá a 'quinta raça,' a 'raça cósmica,' que realizará a concórdia universal, porque será filha das dores e das esperanças de toda a humanidade. Temos de construir essa grande nação, integrando na Pátria Comum todas as nossas expressões históricas, étnicas, sociais, religiosas e políticas. Pela força centrípeta do elemento tupi. (Salgado et al. non. pag.)

[it is from between the Amazon and Plate River basins that the 'fifth race' will emerge, the 'cosmic race' which will accomplish universal peace, because it will be the spawn of the pains and hopes of all humanity. We must build this great nation, integrating within the Common Fatherland all of our historical, ethnic, social, religious, and political expressions. By means of the centripetal force of the Tupi element.]

From the myriad intercultural crossings and conflicts that characterize Brazilian colonial and postcolonial history - for Salgado, a microcosm of world history - the Tupi is thus the central signifier that will unify the four Kantian races (White, Black, Yellow, and Red). The Verde-Amarelo movement offers a re-narration of the past, a narrative that serves as an alternative to the imperial present of Brazilian history. Nonetheless, such an alternative narrative or field of meaning is betrayed by the discursive formations deployed by the movement's members. In other words, their multicultural gnosis, their reading of racial, ethnic, and social difference is very much grounded in the imperial signification of such difference.

Raul Bopp's epic poem Cobra Norato, still regarded as one of Antropofagia's greatest works, has, as Madureira argues, 'closer affinities with the right-wing triumphalism of the nationalistic verde-amarelismo movement [...] than with the more radical antropofagia' (14). Furthermore, Madureira crucially denounces that

the Tupi serves as the key figure in a 'eugenic' romance of miscegenation (between male European migrants and native Brazilian woman). While 
ascribing to noble autochthons a 'spiritual' (i.e., figural) agency, this rhetorical appropriation ultimately reinforces prevalent racist theories, relegating blacks, for instance, to the margins of the narrative of the modern nation. (14)

As Madureira importantly points out, the verde-amarelista arrangement of the nation-sign does not displace the racial underpinnings of the hegemonic national narrative. The nation's white scene of writing is by no means suppressed, and imperial notions of otherness are left firmly intact. This can also be seen in José Vasconcelos's aforementioned essay on the 'cosmic race,' so lauded by the verde-amarelistas. Vasconcelos constructs the cosmic race as an amalgam of imperial notions of otherness regarding race:

How different the sounds of the Ibero-American development [from that of the Anglo-Saxons]! They resemble the profound scherzo of a deep and infinite symphony: Voices that bring accents from Atlantis; depths contained in the pupil of the red man, who knew so much, so many thousand years ago, and now seems to have forgotten everything. His soul resembles the old Mayan cenote [natural well] of green waters, laying deep and still, in the middle of the forest, for so many centuries since, that not even its legend remains any more. This infinite quietude is stirred with the drop put in our blood by the Black, eager for sensual joy, intoxicated with dances and unbridled lust. There also appears the Mongol, with the mystery of his slanted eyes that see everything according to a strange angle, and discover I know not what folds and newer dimensions. The clear mind of the White, that resembles his skin and his dreams, also intervenes. Judaic striae hidden within the Castilian blood since the days of the cruel expulsion now reveal themselves, along with Arabian melancholy, as a reminder of the sickly Muslim sensuality. Who has not a little of all this, or does not wish to have all? There is the Hindu, who also will come, who has already arrived by way of the spirit, and although he is the last one to arrive, he seems the closest relative. [...] we in America shall arrive, before any other part of the world, at the creation of a new race fashioned out of the treasures of all the previous ones: The final race, the cosmic race. $(21,40)$

Vasconcelos's articulation of the cosmic race offers an unrivalled insight into the shortcomings of many formulations of multiracial universals such as that of the Verde-Amarelo movement and, as we shall see, Gilberto Freyre's racial democracy and Lusotropicalism. Vasconcelos's conception of the truly universal race is based on an intercultural dialectic, but one that reads said 
cultures, and constructs the concept of 'culture' per se, through imperial fantasies of ethnic, racial, and religious otherness. For Vasconcelos and the verde-amarelistas, the universal race is not only a product of the antagonisms found within the imperial field of meaning, it is firmly embedded in Empire and resolves said antagonisms without critiquing the violence that guides them. In this regard, the fomentation of this brand of universality is not only in agreement with the desire of Empire, it also articulates an absolute to which Empire guides us. It contributes a teleology to the deep colonial discourse that renders each racial meaning while, most importantly, continuing to confer historical agency upon whiteness.

Regarding the verde-amarelistas, this historical agency is most evident in their own scene of writing. Salgado, Menotti del Picchia, Ricardo, and Bopp usurped historicization while Mário and Oswald aimed to deconstruct it, delinking its imperial bonds of meaning. The verde-amarelistas' fixed centralization of the Tupi as both ideal and prophetic constructer of the multiracial nation is born out of the writers' very imperial scene of writing. The anthropophagic scene of writing that emerges in Macunaima, in contrast, is one that Mário de Andrade labored to disconnect from his own imperial present of the nation through the trope of uninterpellated writing.

It is in reading the Verde-Amarelo movement beneath its multicultural narrative layer that we find the core of Salgado's integralist fascism, its conservative modernity. Although the Tupi image with which it works represents a divorce from Eurocentrism, it is a cultural signifier born from imperial power, the deployment of which does not displace this power. This is always merely a Tupi image, never someone who has suffered the colonial disenfranchisement that comes from having indigenous origins in modern Brazil. The verde-amarelistas, in this regard, do not allow that suffering to speak. The cultural negotiation of the nation-sign is conducted through the Tupi image, as it is palimpsestically narrated from colonial encounter to the modernist present, by members of society whose privilege and right to signify have emerged through the colonial matrix of power. Salgado, as opposed to Oswald and Mário de Andrade, posited the precolonial Amerindian not as a trope for decolonial signification, but as a national ideal and nationalistic prophecy. The precolonial fantasy became an object of truth, a vehicle through which to grip and fix the nation-sign.

It is here that Mário and Oswald de Andrade's version of Antropofagia offers more radical possibilities, and it is in contrast with Salgado that we can observe the singularity, if not the theoretical depth, of Mário and Oswald de Andrade's anthropophagic conceptions. By not centering their cultural project on a particular precolonial fantasy of otherness, and thus reconstructing otherness, Mário and Oswald refrain from speaking 
in the other's place through a false image of it. The voice of otherness is not silenced behind yet another imperially controlled signifier. This subsequently leaves an opening - through an undefined scene of writing - for a more encompassing decolonization to occur. This would be one in which otherness can be contested by the bodies and voices that have been subalternized within imperial power and its social organization.

Antropofagia, as evidenced by both the Estado Novo's nationalistic discourse and the Verde-Amarelo movement, ushered in a decentering of whiteness at the level of the national narrative, while reinforcing whiteness as the privileged scene of writing operating behind the narrative. No post-Antropofagia discourse has had a longer-lasting or more pervasive impact on Brazilian society, however, than the myth of racial democracy ${ }^{1}$ - a narrative of the nation as a multiracial collective that entered the public sphere through sociologist/anthropologist Gilberto Freyre's most celebrated and criticized work, Casa Grande e Senzala. Like Modernismo, Freyre's narrative of Brazil emerged at a time when national elites were looking to assert Brazilian modernity on the international stage. In terms of racial demographics, such assertions intersected with racist discourses of progress, namely eugenics, psychiatry, and whitening policies intended to improve the 'national race' after slavery. At the turn of the twentieth century, the Brazilian state strongly sought the immigration of European workers, not only to constitute an industrial labor force, but also to 'dilute' the blackness of Brazil's population.

On the surface, Freyre appeared to call for an alternative modernity, one that posited Brazil at the global forefront of multiracial humanity. While such eugenic versions of modernity signified racial otherness as un-modern, Freyre's nationalist argument asserted that Brazil was modern precisely because of its multiracial composition. From this premise, Casa Grande e Senzala offers an elaborate re-historicization of Brazilian race relations centering on the relationship between white masters and black female slaves, as the dialectic of national history leading to a twentieth-century present in which Brazilianness is a fusion of cultures - European, Amerindian, and

1 A more nuanced exploration of racial democracy and the work of Gilberto Freyre is beyond the scope of this project. There are several excellent studies that offer rigorous analyses of Freyre's impact on Brazilian race relations. These include, but are not limited to: Abdias do Nascimento's Brazil: Mixture or Massacre; France Winddance Twine's Racism in a Racial Democracy: The Maintenance of White Supremacy in Brazil; Thomas Skidmore's Black into White: Race and Nationality in Brazilian Thought; Jerry Dávila's Diploma of Whiteness: Race and Social Policy in Brazil, 1917-1945; Alexandra Isfahani-Hammond's White Negritude: Race, Writing and Brazilian Cultural Identity; and Lamonte Aidoo's Slavery Unseen: Sex, Power, and Violence in Brazilian History. 
African. Freyre notably translated and built upon the theories in The Casa Grande e Senzala in New World in the Tropics: The Culture of Modern Brazil (1959), which he wrote in English drawing on many contrasts with Anglophone nations, namely the United States:

Men [in Brazil] regard each other as fellow citizens and fellow Christians without regard to color or ethnic differences. Not that there is no race or color prejudice mixed with class prejudice in Brazil. There is. But no one would think of having churches only for whites. No one in Brazil would think of laws against interracial marriage. No one would think of barring colored people from theaters or residential sections of a town. A general spirit of human brotherhood is much stronger among Brazilians than race, color, class, or religious prejudice. (8)

Freyre is, of course, implicitly comparing Brazilian race relations to the Jim Crow laws of the United States, arguing that participation in the Brazilian nation-sign trumps, and is not inhibited by, racial signifiers. Beyond Freyre's ignorance of de facto racism and the social compartmentalization of public space, he omits from his narrative of Brazilian society contemporary power relations that would lead to the emergence of such everyday and systemic racism.

He traces this supposed deficit of prejudice - central to his conception of Brazilian multiracial modernity - back to the Portuguese and the supposed exceptionalism of their model for colonization. Freyre re-historicizes the Portuguese imperial project as one founded not upon the search for control of markets and natural resources, but on love and a mystical desire for intercultural contact and syncretism. In O Mundo que o Português Criou ['The World the Portuguese Created'], where he further develops this thesis, he notably declares: 'I am one of those who attribute the ability of the Portuguese to unite themselves with the tropics for love, not convenience, to the close contacts between the Portuguese in Europe and the Moors' (46).

The consequences of this Portuguese multicultural syncretism can then be found, for Freyre, in Brazilian slavery as the historical foundations for the creation of modern racial democracy:

It is true that racial equality did not become absolute with the abolition of slavery in 1888. But it is true also that even before the 1888 law the relations between whites and colored, between masters and slaves, in Brazil attracted the attention of foreign observers as being particularly cordial and humane. Even before that law, miscegenation had occurred, freely practiced among the people in general [...]. There is in all likelihood no earthly paradise, but in respect of race relations the 
Brazilian situation is probably the nearest approach to a paradise found anywhere in the world. (New World 8-9)

Freyre's positing of miscegenation as the machine behind a modern Brazilian ethos, without analyzing the power dynamics of interracial sex, inevitably leads to a social narrative that obscures racial hegemony. Antonio Sérgio Alfredo Guimarães notably underscores that 'racism is a taboo subject in Brazil. Brazilians imagine themselves as inhabiting an anti-racist nation, a "racial democracy." This is one of their sources of pride and, at the same time, conclusive proof of their status as a civilized nation' (208). Guimarães crucially highlights the still prevalent connection between racial democracy and modern nationhood that Freyre had initially invoked. Denouncing racism, and subsequently pointing out social dynamics of power and privilege constitutes, therefore, an affront to Brazilian modernity in its multiracial narrative.

Underneath the narrative of a non-racist nation that celebrates a collective interracial history is, as Abdias do Nascimento notes, the systemic social and cultural erasure of blackness from the nation-sign; a component also present in the Verde-Amarelo movement. For Nascimento, narratives like racial democracy celebrating miscegenation obscure the crucial connection between the 'sexual exploitation of Black women' and a 'simple genocide' (65). Nascimento goes on to explain: 'with the growth of the mulatto population, the Black race began to disappear' (65). He points out another integral layer of contemporary narratives of Brazilian multiracial nationhood: one that posits 'the presence of African cultural forms, especially in the field of religion' as evidence of a 'history of amiable relations between master and slave and between Blacks and whites in Brazil' (69). According to the logic of racial democracy, the persistence of such forms, without mentioning the immense violence they survived, is also evidence of a flourishing cultural presence of blackness in the nation-sign. This is, however, a liminal and limited inclusion of blackness and black signifiers in the multiracial narrative, concomitant with blackness's increasing marginality and erasure in the envisioning of the nation's future.

\section{Conclusion}

In calling for a decolonial renegotiation of the nation-sign, Antropofagia paved the way for various re-historization projects. The most impactful of these were reactionary to varying degrees and ultimately led to the reconsolidation of the very colonial matrix of power the movement sought to displace. The articulation of a decolonial scene of writing was 
quickly usurped by hegemonic scenes of writing, thus continuing the narrativization of the nation-sign that reproduces its privileged place in the national collective. Mário de Andrade's novel Macunaima, published after his fallout with Oswald de Andrade and Antropofagia, beside tracing ways of reimagining human relations, brings to light the shortcomings and pitfalls of the avant-garde movement. In doing so, it allows us to better understand the political divisions and conflicts within the movement, and especially their repercussions in terms of who participates in the postcolonial signifying process. In terms of the theoretical contributions by, and derived from, Antropofagia, the 'Letter to the Incamiabas' offers a decolonial mode of intervention vis-à-vis imperial subjectivation. In this regard, the letter enacts a theory of formulating a decolonial subject beginning with Macunaíma as an uninterpellated scene of writing. 


\title{
Toward a Multicultural Ethics and Decolonial Meta-Identity in the Work of Fernando Sylvan
}

\begin{abstract}
In recent decades, the study of Lusophone literatures has offered numerous 1 new theoretical perspectives and problematizations of issues pertinent to postcolonial theory and the interrogation of colonial forms of power, both local and global. One geopolitical realm of postcolonial Lusophone literary production that has been relatively under-studied is that of East Timor. Indeed, the particularities of East Timorese history have yielded a rich, if not fragmented, body of literature and cultural reflection that highlights and draws upon the repercussions of territorial occupation (Portuguese and Indonesian) on a multiethnic population. The different projects of cultural invention have sought to explore, question, and push the edges of an East Timorese nation-sign in the historical and intersecting aftermaths of European colonialism, postcolonial, or re-colonial genocide, humanitarian displacement, and neocolonialism in the period of late capitalism.

One of the greatest contributors to such an intervention was this chapter's subject, Fernando Sylvan. Born Abílio Leopoldo Motta-Ferreira in 1917 in Dili, the capital of then Portuguese Timor, he moved to Lisbon as a child, then Cascais to the west of the Portuguese capital, where he lived until his death in 1993. He presided over the Sociedade de Língua Portuguesa [Portuguese Language Society] and received significant acclaim for his poetry in the 1970 s. His poetic æuvre focused, to a certain extent, on themes such as love, deemed universal by the heteronormative male gaze at the gates of the Eurocentric literary canon. Much more significant were his poetic explorations of his Timorese roots from exile, Timorese experiences of resistance against the excesses of European and Indonesian occupation, and the place of East Timor vis-à-vis imperial historicization and global forms of power.
\end{abstract}




\section{Imperial Inscriptions of Colony and Bodies}

Portuguese colonial presence on the island of Timor was consolidated in 1702 with the establishment of Lifau as the capital and the location of the colonial government seat. Portuguese mercantile presence dates back to the early sixteenth century with outposts scattered throughout Southeast Asia. This presence was not sustained, of course, without significant resistance from different Timorese ethnic groups and kingdoms, and faced Dutch military incursions as the Dutch East India company sought to expand its own colonial presence in what is today Indonesia. Following raids by the Topasses, the Portuguese colonial administration moved its headquarters to Dili in 1769 , the present-day capital of East Timor, a nation-state of 1.2 million inhabitants on the eastern half of the island.

The Portuguese crown, followed by the Portuguese Republic, maintained political control over East Timor until the fall of the right-wing Estado Novo $^{1}$ regime in 1974, with a brief interruption during World War II, when Japanese expansion occupied the island from 1942 to 1945. Japanese occupation was preceded by another occupation - that of a Dutch-Australian military coalition in anticipation of a Japanese invasion. The centuries-long Portuguese colonial presence on the island was, many historians have argued, characterized by rampant negligence. Colonial travel writers of the past and historians today point out 'the poor infrastructural condition of the colonial establishment, its military vulnerability, and the patrimonial character of the colonial society' (Roque 306).

Following a visit to East Timor in the early twentieth century, Portuguese poet and traveler José Augusto Fernandes declared that it was a 'damnable colony' and a 'hellish place' (Fernandes 6-8). Raphael das Dores, a coronel stationed in East Timor at the turn of the twentieth century, wrote extensive official documents regarding the colony's ethnic makeup, native political structures, and resources to be extracted for the sake of imperial development. In his Apontamentos para um diccionário chorographico de Timor ['Notes for a Chorographic Dictionary of Timor'], published in 1903, he describes a colonial project that has failed due to interethnic politics, the influence of missionaries, and especially the negligence and lack of investment on the part of Portugal's Overseas Ministry. Colonial governance of Portuguese Timor had been located in Macau, thus underlining the lack

1 The Estado Novo (1933-74) is not to be confused with Getúlio Vargas's Estado Novo dictatorship in Brazil (1937-45). The former will be discussed in greater detail in chapters 5 and 6. 
of importance given to Portugal's easternmost colony. This dysfunctional state of affairs led das Dores to declare:

é minha convicção que, para que Timor possa deixar de ser um cancro nos réditos públicos e gravíssimo encargo para Macau, como tem sido, ou, para melhor dizer, para que entre no convívio da civilização, seria indispensável que um Ministro do Ultramar que conhecesse perfeitamente a colónia, ou chamasse quem a conheça, formulasse dedicadamente um plano sobre a sua administração. (7)

[it is my conviction that, for Timor to cease being a cancer on public revenues and a grave burden on Macau, as it has been - or, to put it better, so that Timor may enter civilization - it would be indispensable for an Overseas Minister who knows the colony well, or knows someone who does, to formulate a plan for its administration.]

Raphael das Dores's loathing for East Timor points to his investment in turning it into a lucrative colony for the Portuguese crown. He thus offers terse observations regarding the failure of the Overseas Ministry to develop a substantive agricultural economy based on the exploitation of native labor. He repeatedly underscores the Ministry's failure to 'civilize,' and subsequently dominate, the various ethnic groups that comprised the colony. It was arguably to this end that he undertook his next project of imperial knowledge production on the colony. Published in 1907, das Dores wrote a Tetum-Portuguese dictionary, a complementary follow-up to the Jesuit Sebastiáo Apparicio da Silva's Portuguese-Tetum dictionary, published in 1889. Raphael das Dores's preface to the dictionary interestingly calls for the political elevation of Tetum to the status of co-official language of the colony - which it holds today in the postcolony. This further highlights how colonial objectives of domination of native others through linguistic translation shapes the ethnolinguistic landscape of the postcolony: a particularly relevant issue considering that the linguistic makeup of East Timor consists of roughly 30 different Austronesian and Papuan languages. While Portuguese is considered the colonial language, Tetum is also a colonially imposed language. As such, it has been met with significant resistance in the decades following Portuguese colonialism.

The 1920 s brought forth further anthropological and ethnographic works from Portuguese travelers. In 1928, Alberto Osório de Castro published what João Paulo Esperança calls 'um peculiar livro de viagens' ['a peculiar travel book'] (1) written in poetic prose with lengthy descriptions on the flora and fauna of Timor Island, as well as its inhabitants. Another traveler, Paulo Braga, also wrote extensively on Portugal's easternmost colony, publishing 
five books on Timorese cultural life with such revealing titles as A Itha dos Homens Nus ['The Island of Naked Men'] (1936) and Timor 1930: País de Sonho e Encantamento ['Timor 1930: Country of Dreams and Enchantment'] (1930). The titles themselves indicate the exoticism and primitivist notions of human purity (located outside the West) with which Portuguese travelers signified the island.

Travelers, or knowledge producers, from other European imperial nations also wrote on the topic of colonial inefficiency in East Timor and Portuguese civilizational incapacity. In his study of the flora and fauna of Southeast Asia, The Malay Archipelago: the land of the orang-utan, and the bird of paradise. A narrative of travel with studies of man and nature, the British naturalist Alfred Russell Wallace dedicates a chapter to Timor Island. In addition to naming, categorizing, and establishing taxonomies of plant and animal life, Wallace also offers reflections on the colonial organization of human life he encounters in the Dutch and Portuguese domains, thus underscoring the intimate bond between imperial consciousness and the production of colonial knowledge. Wallace's reflections inscribe both Portuguese and Timorese otherness vis-à-vis northern European standards of Western civilization. He offers lengthy descriptions of ethnic categories and ways of life, prefaced by the epistemic statement, specifically regarding the capital, that 'there is no sign of cultivation of civilization about it' (145). What follows, therefore, is a catalog of otherness:

The mountaineers of Timor are a people of Papuan type, having rather slender forms, bushy frizzled hair, and the skin of a dusky brown colour. They have the long nose with overhanging apex which is so characteristic of the Papuan, and so absolutely unknown among races of Malayan origin. On the coast there has been much admixture of some of the Malay races, and perhaps the Hindoo, as well as of Portuguese. The general stature there is lower, the hair wavy instead of frizzled, and the features less prominent. The houses are built on the ground, while the mountaineers raise theirs on posts three or four feet high. The common dress is a long cloth, twisted round the waist and hanging to the knee. (Wallace 305-06)

In the realm of literary production, Joseph Conrad, one of the twentieth century's most impactful writers of Empire and its field of meaning through tales of European agency in the global South, also inscribed East Timor as a place of overlapping otherness. In his 1915 novel, Victory, Swedish businessman Axel Heyst finds himself residing in the Dutch East Indies, modern-day Indonesia, as a result of a business endeavor. He tours different islands of the Dutch colonial domain, as well as the French and Portuguese 
colonies. In relating Heyst's time in Dili, Conrad's narrator introduces the city as 'that highly pestilential place' made up of 'God-forsaken villages' that are home to 'a very hungry population clamorous for rice' (15). As is customary in Conrad's fiction, it is the otherness of colonial poverty that serves as the background for the Eurocentric action of the novel. There is, though, a connection between the images of abject 'uncivilization' with which Conrad's narrator inscribes the Timorese residents of Dili and the otherness of the Portuguese vis-à-vis the embodiment of Europeanness that is the protagonist.

While in Dili, Heyst becomes acquainted with Morrison, a British expatriate who is being pursued by the Portuguese colonial authorities. Having spent a significant time under persecution in Dili, Morrison seems relieved to finally find a fellow white man:

He had been wandering with a dry throat all over the miserable town of mud hovels, silent, with no soul to turn to in his distress, and positively maddened by his thoughts; and suddenly he stumbled on a white man, figuratively and actually white - for Morrison refused to accept the racial whiteness of the Portuguese officials. (17)

The articulation of the Portuguese as not racially white is very much a confluence of darker racial features (in comparison with those of Heyst), the geographical location of Portugal on the southern margins of Europe, and perhaps most importantly in the context of colonial endeavor - the perceived Portuguese inability to fulfill the paternalistic mandate of the white man's burden. Morrison's conception of the Portuguese as not racially white arguably owes much to anthropological reflections on the racial makeup of Europe during the nineteenth and early twentieth century. Contributors to the field of racial taxonomy - an integral academic component of eugenics - such as William Ridley argued famously that 'Africa begins beyond the Pyrenees' (272), and that Europe was made up of three races: the Teutonic of northern Europe, the Alpine of central Europe, and the Mediterranean of southern Europe which shared anthropometric characteristics with North African racial groups. As Portugueseness resides on the limits of a phantasmatic European episteme, it is thus unsuited to articulate such an episteme on the other. The Portuguese deficit of whiteness is thus both the explanation and consequence of Portugal's colonial incapacity.

This series of political and cultural reflections on colonial East Timor from different imperial perspectives traces a spectrum of global imperial power, manifested by claims to European notions of civilization that posit Great Britain over Portugal over Southeast Asia. Rather than focusing on what 
this position of relative subalternity means for the legacies of Portuguese colonialism and post-imperial identity, ${ }^{2}$ this chapter is more concerned with the various layers of colonial historicization that have ensnared and signified East Timor and the experiences of its residents, as well as how writers of the past half-century have grappled with this palimpsest of imperial signification. Imperial inscriptions of East Timor have inevitably influenced and structured the political decisions taken over its inhabitants, from colony to postcolony, re-colony, and postcolony once again, impacted by foreign interests, such as those of Portugal, Indonesia, Australia, and the United States.

Portuguese colonial presence, tenuous as it may have been, nonetheless inserted the colony and its people into the logocentric, imperially formulated realm of History, the Western narrative of the past and reigning realm of intercultural meaning. As Luís Madureira reminds us, the goal of postcolonialism's idiom of inquiry must continue to be 'to reconsider the history of slavery, racism, and colonization from the standpoint of those who endured its effects' ('Difference' 141). Part of the challenge taken on by some East Timorese writers has been to fathom a realm of meaning that eludes the structure of representation that, despite Portugal's imperial limitations, accompanied colonial domination, slavery, and economic exploitation of natural resources on the island.

Aside from political documents tracing the physical space, ethnic makeup, and linguistic productions of East Timor, the colony was a central focal point for much Portuguese orientalist fiction in the nineteenth and twentieth century. Grácio Ribeiro's Caiúru (1939) is a prime example of the orientalist strand of fictional portrayals of East Timor and Timorese lives. The semiautobiographical novel follows a young Portuguese man on the island following his deportation from Portugal for involvement in the clandestine communist party. Within the context of the plot's central intercultural encounter, the foundation of the protagonist's identitarian performance is the access to land, bodies, and capital afforded to him by his whiteness within the imperial field of meaning. In the Western narrative of time and space, whiteness, as the racial embodiment of Westernness, bestows upon its subject such freedom to consume, as we explored in Chapter 1.

2 For a larger discussion on the tenuous place of Portugal and the Portuguese empire within a global economic system, see Boaventura de Sousa Santos's seminal essay 'Between Prospero and Caliban: Colonialism, Post-Colonialism and Inter-Identity.' Equally important is Luís Madureira's response to it in 'Is the Difference in Portuguese Postcolonialism the Difference in Lusophone Postcolonialism?' and 'Nation, Identity and Loss of Footing: Mia Couto's O Outro Pé da Sereia and the Question of Lusophone Postcolonialism.' 
This access to bodies is, of course, constructed through different forms of intersectionality that inform identity politics in the colonial space and the imperial realm of power and meaning. The protagonist's experience on the island is, in other words, framed by the intermingling of whiteness, masculinity, and capital, most glaringly underscored by the detailed account of the protagonist's purchase of a nona, a term that became part of colonial Portuguese parlance in East Timor for an unofficial female sex worker, often thought of as a paid mistress or lover (amante). In his A terra, a gente e os costumes de Timor (1939), the aforementioned Paulo Braga offers a detailed exoticizing account of the presence of nonas in public spaces, namely Dili's bazaars:

Nas ruas de Dili e nos bázares desfilam as nonas, saltitantes nas sóquinhas e nas sandálias, reluzentes nas sêdas e no ouro dos cordóes, das cruzes e das escravas. São as amorosas de Timor, semelhantes às amorosas de todo o mundo, talvez mais exóticas e mais originais. [...] E, no bázar, a gente acotovela-se, animada. Com o europeu, cruzam o indiano, o árabe, o china, o timor. [...] Pisam o empedrado ou o cimento os sapatos de lona e borracha dos ocidentais, as sandálias e os chinelos dos chinas, as socas das nonas e os pés descalços, num amálgama cosmopolita e simpático.

E tudo se resolve na tarefa do negócio. Só o europeu não compra, nem vende. Năo o leva alí uma finalidade de interesse comercial, mas apenas uma curiosidade ou uma imposição sentimental. Vai ver as nonas que existam e as possibilidades de nonas que porventura apareçam. Por isso, não olha géneros agrícolas e pecuários ou os artefactos expostos. Procura, apenas, as mulheres. $(11,35)$

[In the streets of Dili and in the bazaars parade the nonas, bouncing in their sandals, gleaming in their silk garments, gold necklaces, crosses and gaudy bracelets. They are the call girls of Timor, like call girls from around the world, perhaps more exotic and original. (...) And in the bazaar, people joyfully rub elbows. The European encounters the Indian, the Arab, the Chinese, the Timorese. (...) On the stone or cement walkways step the canvas and rubber shoes of the Westerners, the slippers and sandals of the Chinese, the clogs of the nonas and bare feet, in an agreeable cosmopolitan mixture.

All actions here revolve around business matters. Only the European does not buy or sell. He is not guided by commercial interest, but only curiosity or a sentimentality. He goes to see the nonas who are there and the chances of nonas appearing. As such, he does not look at agricultural commodities or the artifacts on display. He looks only for women.] 
Braga's exoticist take on the circulation of bodies in Dili suggests that the presence of nonas seems inextricably tied to the development of the bazaar space as a locale of interethnic contact, where different bodies hold different cultural, racial, and sexual currencies. Moreover, Braga seems to reveal a key component of colonial reality and the significational formation of colonial space. The presence of nonas exists in a market space of supply and demand that is very much dictated by a foreign male gaze pertaining to an international masculine bourgeoisie. Through such an economy of desire embedded in a colonial economy and societal compartmentalization, regulated by the aforementioned gaze, socioeconomic stability is facilitated for subaltern bodies almost exclusively by foreign desire in the market. The sexual case of nonas is perhaps most clearly indicative of this, but the same is also true for most goods on sale at the bazaar. In the excerpt above, there is a pronounced consumer/vendor divide that is very much articulated in terms of a foreigner/native dichotomy.

Another literary text that asserted white imperial agency vis-à-vis colonized otherness in terms of inter-gender politics and interracial sex is the short novel A nona do Pinto Brás (Novela Timorense) [Pinto Bras's Nona (A Timorese Novel)] (1992) by Filipe Ferreira. Esperança argues that, due to prose similarities, this may have been the literary pseudonym of famed colonial historian Luís Filipe Ferreira Reis Thomaz (2). It was not only white Portuguese masculinity that found in East Timor the ethnic and racial topography necessary to inscribe itself. Isabel Tamagnini's Diário de uma Viagem a Timor ['Journal of a Journey to Timor'] (1882) serves as a vivid example of how the act of writing the colony and its inhabitants also permitted the expression of notions of white womanhood, and especially white female agency, within an otherwise masculine concentration of colonial power. Although the diary is written for an intimate audience (Tamagnini's cousins and friends in Portugal) during her travels in the Far East, it gives Tamagnini the opportunity to articulate a personal narrative of the metropolitan aristocracy through the imperial field of meaning that ensnares the colonial space through racial and sexual taxonomies.

In the final decades of Portugal's political control over East Timor, Portuguese colonial presence remained sparse, especially outside of Dili. Nonetheless, the furthest colony from the metropolis maintained a central symbolic place in Portugal's late imperial narrative of a 'pluri-continental nation,' as evidenced by its presence in the nation's motto: 'from Minho to Timor.' Its symbolic impact on the imperial narrative derives, mainly, from its role demarcating the empire's expansive boundaries, the domain infamously articulated by the mapa cor de rosa [pink map]. As a signifier of Portugal's overseas empire, Timor was deployed as part of the linguistic 
representation of a Portugal that was 'not a small nation,' this being the oft-repeated clause that customarily followed, preceded, or substituted the ideological assertion that Portuguese national territory extended from the Minho region of northern Portugal to Timor.

In the face of international pressure to decolonize following World War II, Estado Novo propaganda defended the persistence of Portuguese colonial presence in Africa and Asia on the grounds that these holdings were not colonies, but overseas provinces that were integrated and equal parts of the pluri-continental nation. In fact, the term integration became a core component of Portugal's late colonial propaganda machine and its imperial re-historicization. This reformulation of the colonial past into a narrative of cultural syncretism that occulted the quotidian and institutional violence of colonial power was most famously, though not exclusively, undertaken by Gilberto Freyre. As noted in Chapter 2, the Estado Novo funded Freyre's tour of the Portuguese colonies in the 1950 s following his previously established historical arguments that the Portuguese were colonizers more concerned with benevolent intercultural contact and sympathy than nefarious financial aspirations. He thus conceived Portugal and its colonies as equal parts of a Lusotropical civilization. In one of the written products of his journey through 'terras portuguesas' ['Portuguese lands'], O Luso e o Trópico [The Luso and the Tropical] (1961), Freyre defines an integrated society:

Integrar quer dizer, na mesma linguagem especificamente sociológica, unir entidades separadas num todo coeso, um tanto diferente da pura soma das suas partes, como se verifica quando tribos ou estados e até naçōes diferentes passam a fazer, de tal modo, parte de um conjunto, seja nacional ou transnacional, que dessa participaçăo resulta uma cultura, senão homogênea, com tendência homogênea, formada por traços mutuamente adaptados - ou adaptáveis - uns aos outros. Assim compreendida, a integração contrasta com a subjugaçáo de uma minoria por uma maioria; ou - pode-se acrescentar - de uma maioria por uma minoria, contrastando também com a própria assimilação. (313)

[In specifically sociological terms, integrating means uniting separate entities in one cohesive whole, a little different from the pure sum of its parts, as verified when different tribes or states and even nations become part of a collective, be it national or transnational, which participation results in a particular culture that, if not homogenous, has homogeneous tendencies, formed by mutually adapted - or adaptable - traces. Understood in this way, integration contrasts with the subjugation of a minority by a majority, or - we may add - that of a majority by a minority, thus contrasting also with assimilation.] 
The Lusotropical civilization is one in which, according to Freyre, all ethnicities partake. The legitimization of this narrative hinged on its position as a transcontinental nationhood in which all ethnicities purportedly wanted to participate. Freyre attributes the Lusotropicalism of then Portuguese Timor, despite sparse Portuguese political presence and investment, to Timorese loyalty to the Portuguese: 'Só por espontânea lealdade dos nativos de Timor aos portugueses é que Timor continua lusotropical' ['Only through the Timorese natives' spontaneous loyalty to the Portuguese does Timor continue to be Lusoptropical'] (Aventura 409).

In voicing the imperial narrative, Freyre must speak for, and thus construct, the desire of the colonized subject to be part of a reformulated field of imperial meanings. The inscription of cultural difference in the Lusotropical narrative must simultaneously provide an answer to the perennial colonial question: What does the other want? The true - not imperially historicized - desire of the colonial other must first be prevented from participating in signification - the making of meaning - and then spoken over, the desire of the colonized being articulated from the desire of the imperial writing subject.

Freyre explains this phantasmatic Timorese desire for Portuguese presence by reverting to his consistent line of argumentation tracing a Portuguese ethos that resides between Europe and the global South. In contrast to Morrison, the drifting Englishman in Conrad's Victory, Freyre's narrative celebrates Portugal's supposed deficit of Europeanness and uses it to explain Timorese desire for the Portuguese, especially in comparison with the Dutch presence on the Western half of the island:

Timor, metade holandesa, metade portuguesa, foi não só invadida por japoneses como agitada por ásperas revoltas de nativos contra o 'europeu.' Mas europeu - imperialista europeu - era, aos olhos desses nativos insurretos, o holandês; o português, eles o consideravam português: à parte dos europeus. (Aventura 409)

[Timor, half-Dutch, half-Portuguese, was not only invaded by the Japanese, but also shaken by harsh revolts by natives against the 'European.' But European - imperialist European - was, in the eyes of the native rebels, the Dutch; they considered the Portuguese simply Portuguese, separate from Europeans.]

Following Portuguese decolonization in 1975 and the declaration of Timorese independence on November 28 by the leftist Fretilin (Frente Revolucionária de Timor-Leste Independente) party, the Indonesian military, led by President Suharto invaded East Timor on December 4, 1975. The invasion was carried out with significant Western support, namely from the 
United States, with the goal of preventing the spread of Soviet-supported communist presence in Southeast Asia. East Timor was now part of at least two more imperial narratives - that of expansionist Indonesia as the nation's twenty-seventh province, and that of the neoliberal United States, which posited East Timor as a threat to capitalist markets in the region. This signification of newly independent East Timor as a threat to an existing political and economic regional and global order was also central to Australian foreign policy regarding East Timor, and also to Suharto's rationale to invade. East Timor became ensnared in Suharto's New Order narrative and his return to a particular version of Pancasila, the political philosophy of the Indonesian state: a version that distanced itself from populist socialism. Most importantly, the political narratives of Indonesia, Australia, and the United States were profoundly intertwined and served one another. Not surprisingly, historian David Hicks begins his book Rhetoric and the Decolonization and Recolonization of East Timor (2014) with a concise summary of East Timorese experiences of global power: 'As always for the people of Timor, their lives would be changed by others ignorant of their concerns and geographically distant' (2).

\section{Decolonizing the Pluri-Racial Nation, or, Fernando Sylvan's Ambiguities}

East Timor's place at the limits of Portugal's imperial narrative is also reflected in its almost invisible place among an international readership in Portuguese. Although this has changed slightly following the international attention garnered by the 25-year Indonesian occupation, it was very much the case before Portuguese decolonization and largely continues to be the case for contemporary writers. The relative lack of critical recognition of East Timorese letters has largely relegated to the margins of Lusophone literary and cultural studies one of the most prolific thinkers of Portugal's imperial project (especially its final decades), Portuguese national identity, and its relationship with the ethnic diversity of its colonial holdings Fernando Sylvan. His prolificacy encompasses and traverses literary genres and even academic disciplines ranging from political theory to education and ethnography. Sylvan published nine collections of poetry; two theater screenplays; innumerable articles on a range of topics pertinent to Timor, Portugal, Brazil, and East Africa; and 11 books on Portuguese imperialism and East Timorese folklore in addition to a series of personal memoirs.

The decade of his most significant poetic production (1972-82) was anteceded by his most prolific period of essays and cultural reflections, a period that notably intersects with the beginning of the end of Portugal's 
overseas empire. Indeed, in order to more fully understand the voice behind his verse of the 1970s, it is important to consider the nuances of Sylvan's essayistic work, especially regarding his poetic engagement with the practices and legacies of Portuguese colonialism and a global world order.

At the height of the Estado Novo's international promotion of Portugal as a 'pluri-continental' nation, Sylvan's work served as an ambiguous interlocutor to such a narrative. His earliest publications seemed to align themselves with Estado Novo propaganda and the Lusotropicalist narrative of the Portuguese empire and ethos. In 1960, he published the essay 'Arte de Amar Portugal,' which found a receptive audience among Lusotropicalism's apologists, especially its central invocation of Portugal as a 'pátria' ['fatherland'] with which even someone of non-European descent born in a Portuguese colony could identify.

Published in 1962, his Comunidade pluri-racial [Pluri-Racial Community] expanded the arguments delineated in his earlier essay while proposing models for the praxis of Portugal as a multiracial community. The book's publication came at a very significant time for Portuguese colonial politics and its Lusotropical narrative - namely the beginning of anti-colonial struggles in Angola and the integration of Portugal's Indian colony, Goa, into post-independence India. Sylvan thus offered a cultural and political blueprint for the idea of a multiracial community as its real-world counterpart began to disintegrate.

Sylvan's work here does not call for an anti-colonial stance, but instead proposes policies that would enable Portugueseness to become a truly multiracial communal entity without assimilation into a metropolitan cultural expression. He calls for a Portuguese consciousness from 'Minho to Timor' across lines of ethnicity, while maintaining ethnic identities. His theory of a multiracial and transcontinental community operates under an ambiguous dichotomy of nation versus state. The nation, Sylvan argues, should not be a 'discipline of the state' (Comunidade 22). Such a state-driven version of the nation fails to express

a floração total dos indivíduos e, ao contrário, obriga-os a marcharem e a aceitarem conclusóes que são alheias à sua dor e ao seu sorriso, que não demonstram, portanto, nem a sua alma, nem o seu pensamento. 0 acontecimento da Pátria fica então comprometido fortemente e por ela se toma o que não é mais do que uma disciplina de Estado geradora de um Estado que só pode subsistir pela força. (Comunidade 22)

[the full flourishing of individuals and, to the contrary, forces them to accept conclusions that are far removed from their pain and from their joy, that do not demonstrate, therefore, either their soul or their 
thoughts. The affairs of the Nation become, then, greatly compromised and understood as merely a discipline of the State, generating a State that can only exist by force.]

The central ambiguity, if not contradiction, of the work lies in the proposed alternative to a state-driven model of nationhood with the metropolis as its cultural and racial core. Sylvan calls for a

função pedagógica em que seus agentes estejam plenamente inteirados dos imperativos nacionais do seu magistério. Só uma engenharia social pode dar a esses agentes as linhas mestras do seu labor e ser alicerce do entendimento de Pátria Portuguesa para além da quotidiana vivência de Estado político. (Comunidade 22)

[pedagogical function in which its agents fully comprehend the national imperatives of their education. Only a social engineering project can offer such agents the tools through which to understand the Portuguese nation beyond its quotidian existence as a political state.]

At the heart of Sylvan's proposal is the utopia of a transcontinental and multiracial narrative of nation that does not serve nor emanate from the state.

This requires, as he points out, a rethinking of interpellation into such a narrative, a process that would thus be contingent upon a new mode of institutional action. This would be what Sylvan calls an 'instituiçãocorpo' ['body-institution'] (23) through which individuals across ethnicities identify with the community. He posits the 'body-institution' as opposed to the 'instituição-pessoa' ['person-institution'] (23); or rather, argues that the former must precede the latter. The pedagogy of a community operating within Sylvan's model implies an institution that is simultaneously a frame of identification - the frame through which individual ethnic identity must emerge.

The fundamental conflict in his proposal, to put it clearly, resides in the call for the maintenance of ethnic specificities while suggesting that the community/nation take precedence over ethnicity in the way that individuals relate to History. His version of interpellation seems to present a twist of W. E. B. Du Bois's notion of double consciousness (Du Bois 3). Rather than racial/ethnic consciousness and national consciousness consistently problematizing one another, national consciousness, according to Sylvan's reformulated interpellation, must take precedence over ethnic consciousness. Moreover, it is the frame of national consciousness that should formulate notions of ethnic identification. Sylvan nonetheless argues that through this 
process, 'conjuntos étnicos diferentes poderão em breve, de motu-próprio, processar-se em Estado e transcender-se em Pátria' ['different ethnic groups will be able to, in their own way, articulate themselves as part of the State and transcend themselves in the Nation' (Comunidade 24).

Within the overarching identitarian framework of transcontinental Portugueseness, ethnicityis to be simultaneouslymaintained and transcended. Through this ambiguous process, nation, particularly transcontinental Portugal, becomes the 'região única ideal onde grupos de homens da mesma raça ou de raças diferentes unidos em trânsito histórico têm no eterno a sua morada mental futurante' ['unique ideal region where groups of people of the same race, or of different races, united in historical movement, have a future and eternal psychic home'] (Comunidade 41). The interpellation into a narrative of a common past becomes the preferred path toward the fundamental feature of Sylvan's tracing of a nation that supersedes ethnicity and the state - a common future as a shared psychic space.

Beyond the undeniable utopianism of this formulation, Sylvan does, to some degree, take the dominant Lusotropicalist narrative of Portuguese imperialism to task, demanding that it be what it claims - a nation, not a colonial structure:

O sentido de exploração, de enriquecimento fácil, de alheamento dos supremos interesses autóctones que ditou a implantação no Ultramar Português das primeiras empresas e sociedades e actividades económicas pessoais, se não teve nunca razão de ser, muito menos poderá hoje ser justificado. $\mathrm{O}$ que não foi ainda rectificado, terá de o ser, porque não se pode sacrificar o destino de milhóes aos interesses apenas de alguns, porque não se pode escoar o Ultramar em benefício da Metrópole, porque não será possível concretizar a unidade sem ser no interesse igual de todos. (Comunidade 72)

[If the logic of exploitation, of easy accumulation, of the marginalization of native interests that established within the Portuguese maritime empire its earliest companies, societies, and personal economic activities made no ethical sense then they are much harder to justify today. What has not yet been rectified must be, because the destiny of millions cannot be sacrificed for the interests of a few, because the overseas territories cannot be drained for the benefit of the metropolis, because it will not be possible to achieve unity if it is not in the equal interest of all.]

Sylvan does not, therefore, focus on a narrative of Portuguese transcontinentality, but rather underscores the importance of a shift in economic 
policies that informed the relationship between metropolis and 'provinces.' In pinpointing the 'interests of a few' driving Portuguese colonialism's economic endeavor and concomitant system of representation, Sylvan conceives of this pluri-racial nation as one based on the redistribution of power - its geographic, racialized, and gendered location. In his view, the starting point for this shift would be economic:

Tudo o que se prometer, tudo o que se fizer ficará incompleto, melhor mesmo, impossibilitado de expressar-se, se à amplitude de uma acção política e à profundidade pedagógica se não juntar a revoluçăo de uma acção económica. Quer dizer: sem esta revolução, a amplitude política será virtual e não real e a profundidade pedagógica será também virtual e não real. (Comunidade 72-73)

[All that is promised, all that is begun will remain incomplete, or rather barred from expressing itself, if to breadth of political action and pedagogical depth we do not add an economic revolution. In other words: without this revolution, political breadth will be merely virtual and not real, and pedagogical depth will also be virtual and not real.]

Rather than reading Sylvan's stance as one that simply places more importance on class and economic processes over race on the path to the goal of social justice, he understands imperial racial meanings to be part of the ideological support and text for economic exploitation - racial difference being an imperial criterion for the division of labor. Unlike Freyre, Adriano Moreira, and other Lusotropicalist proponents of his time, Sylvan recognizes, perhaps only tacitly, the systemic racism of the status quo in further elaborating the political and economic contours of his version of the multiracial nation:

É importante também que as actividades económicas não sejam um motivo de discriminação racial [...] a verdade é que uma actividade económica que distribui o trabalho segundo a raça não pode subsistir se não se rectificar. Constitui mesmo uma indignidade de quem o impõe ou o consente, pois que, uma vez abolido o esclavagismo, não pode manter-se qualquer atitude que ainda que só de longe com ele se relacione. (Comunidade 74)

[It is equally important that economic activities not be a motive for racial discrimination (...) the truth is that an economic activity that divides labor cannot continue if it is not rectified. This constitutes an indignity for he who imposes such a distribution as well as for 
he who allows it, since, as slavery has been abolished, any practice or attitude even distantly related to it must be deemed impermissible and unsustainable.]

This particular passage effectively underscores the intersectionality of imperial exploitation and the profound presence of imperial discourses of racial difference that continued to mark the implementation of Portuguese colonialism during the Estado Novo's embrace of Lusotropicalist narratives effacing race-based subalternity from the public record. As recent historians, beginning with Gerald Bender and his Angola under the Portuguese: The Myth and the Reality, have uncovered, forced labor based on race was rampant throughout Portugal's colonial holdings during the Lusotropicalist period. A contemporary of this era of late Portuguese colonialism, Sylvan offers here an ambivalent rebuttal to Lusotropical claims of improved race relations while also subscribing to the tenets of Estado Novo propaganda of pluri-racial nation as utopian goal.

Despite criticizing contemporary economic policies driven by the imperial metropolis, Sylvan does not displace the central tenets of metropolitan imperial culture, namely the glorification of early modern Portuguese imperial endeavors. Interestingly, he juxtaposes the colonial economic exploitation undertaken by colonists of the mid-twentieth century to the, for him, laudable accomplishments of the fifteenth- and sixteenth-century Portuguese involved in the period known as 'the Discoveries':

Na verdade, esses colonos que daqui saíram descalços e no Ultramar acumularam quantias que não se podem técnicamente explicar, não levavam já consigo o espírito de aventura que era a característica da nossa gesta, espírito que ainda foi uma das forças poderosas que animaram os Descobrimentos. (Comunidade 75)

[In truth, those colonists who left here (the metropolis) barefoot and accumulated inexplicable wealth in the overseas territories did not take with them the spirit of adventure characteristic of our history, the spirit that was a powerful force behind the Discoveries.]

Revealingly, such a contrast fundamentally plays into the metropolitan reformulation of the Discoveries and the colonial encounter they entailed by stripping from the equation the exercise of power they inaugurated. This rearticulation of the Discoveries, unlike the emancipatory practices we explore here, is much more closely aligned with the Lusotropicalist reformulation of power relations for the sake of a narrative based on the lack of violent social and economic structures. 
The excerpt above also points to another limitation of Sylvan's theorization of the transcontinental community and its multiracial narrative. It indicates that his articulation of the community, despite its evocation of intercultural negotiation of meaning and denunciation of economic and racial exploitation, does not displace the centrality of metropolitan cultural signifiers. The championing of a truly egalitarian intercultural exchange central to the community is usurped by a continuity in metropolitan cultural hegemony.

Another of his works, published two years later, O Racismo da Europa e a Paz no Mundo ['The Racism of Europe and World Peace'] (1964), fleshes out Sylvan's understanding of European colonialism and its discursive underpinnings. In doing so, the book contradicts some of the positions taken by Sylvan in Comunidade Pluri-Racial by gesturing toward a more radical political position regarding European imperial endeavors and the field of meaning these reproduced. In his preface, Sylvan frames O Racismo as a book that 'expressa um grito longo de crente desobediência à Europa' ['expresses a long cry of faithful disobedience to Europe'] (18) while also offering 'fórmulas de vigoroso combate à atávica aceitação do jugo europeu' ['formulas for vigorously combating the atavistic acceptance of the European yoke'] (O Racismo 18).

Sylvan begins his exploration of European racism, specifically the racial underpinnings of European colonial projects, by targeting the philosophical core of Empire - the phantasmatic formulation of selfhood and otherness. He argues that European thought and philosophical reflection 'raramente têm entendido o que é o Homem, ou raramente se têm interessado por tal entendimento. Compenetraram-se de que o Homem era o homem europeu' ['has rarely understood what is Human, or has rarely taken an interest in such an understanding. They have convinced themselves that Man is European man'] (O Racismo 21). In this regard, Sylvan pinpoints what Enrique Dussel would later theorize as the 'archetypal foundational I' (8) operating behind European colonial discourse - the psychic heart of an imperial Weltanschauung and scene of writing from which the Western narrative of History and imperial field of meaning is articulated. Aimé Césaire notably situated this ' $I$ ' as that of the 'Western humanist' - one whose injunction is carried out by the practitioners of a colonial order, those who should not 'object to the European colonial enterprises' (Discourse 3-4).

Aside from pointing out the European philosophical equation of European man as the embodiment of humanity, Sylvan also posits Eurocentric humanitas as fundamentally monological: 'os europeus colocaram-se a si próprios na posição de mestres, quando os mestres verdadeiros são os que nesse plano são colocados pelos que com eles aprendem' ['Europeans placed themselves in the position of masters, when the true masters are those 
deemed such by those who learn with them'] (O Racismo 23). The articulation of a phantasmatic other and speaking for this other, foreclosing its desire and inscribing in its place, reproduces the self-position of European man as I. This is the core of the monologic field of imperial meaning where the imperial I is also the 'civilização-padrăo,' ['standard civilization'] (O Racismo 26), which Sylvan contrasts with the search for a true Human existence. In 'dilating' (O Racismo 25-26) its signifying field into an exercise of global power, Europe failed to serve itself in the aforementioned quest: 'porque os homens e os povos só em amplitude se servem quando o fazem sem medida de espaço e tempo, como garantia de que todos e um se acontecem' ['because humans and peoples are only served without limits of time and space, as a guarantee that all have a right to exist'] (O Racismo 26). Sylvan crucially separates Césaire's Western humanist from a greater understanding of humanitas, the latter being a fundamentally dialogical undertaking, never carried out through a hegemonic scene of writing.

For Sylvan, it is from this foundational monologicism that emerges the fallacy of European supremacy. He asserts that the early modern field of imperial meaning where racial inequality was established by a singular site of articulation led to a fantasy of superiority that later European and European-descendent generations could not prove (O Racismo 83). Sylvan does not argue, however, that such generations did not try. He asserts that such superiority and the range of identities it implies exist only in a symbolic realm over the Real void of such superiority. As such, its subsequent atrocities occur through the repeated performance of superiority as the tool to reproduce the symbolic distance from the Real. For Sylvan, this is both a theory of Empire and a call to action against it. He argues, furthermore, that racial and ethnic signification can unite as much as it has divided so long as notions of supremacy are elided. Herein lies the fulcrum of his potential decolonial ethics - a dialogism that forecloses notions of centrality and supremacy. The resignification of difference from its original colonial articulations, he argues, must be ushered in by 'os povos que viveram sujeitos a regimes coloniais' ['the peoples that lived under colonial regimes'] (O Racismo 135) in response to the excesses reproduced by Europeans and Euro-Americans - those who have carried out the fantasy of a 'civilizaçãopadrăo.' He elaborates:

não se trata propriamente de uma luta de afro-asiáticos contra os demais povos, pois eles não desejam anular o resto dos homens ou obstruir a marcha da Humanidade no novo caminho que se intui. 0 que acontece é ter-lhes competido forçar o novo rumo, rumo em que os europeus e os euro-americanos não foram capazes de abertamente se 
lançar, em grande parte por considerarem para si próprios um perigo a igualdade de direitos. E em perigo afinal se coincidiam, porque coagindo os demais a si próprios se não libertavam, porque não pode haver liberdade parcial em conceito, que o conceito de liberdade é só um. (O Racismo 136)

[this is not necessarily a struggle of Afro-Asians against all other peoples, as the former do not wish to destroy the rest of humankind or to obstruct the march of Humanity down the path proposed here. Rather, it has fallen to Afro-Asians to inaugurate a new path, one that Europeans and Euro-Americans were unable walk, in large part because they considered equality to be a threat to their interests. The threat, though, was inevitable, because in oppressing the rest they never fully freed themselves. There could be no partial freedom, as there can only be one concept of freedom.]

Sylvan's stance notably asserts that Europeans are also ensnared by the imperial field of meaning in which they reside, while echoing Malcom X's iconic 1964 speech 'The Ballot or the Bullet': 'It's liberty or death. It's freedom for everybody or freedom for nobody.' In this regard, the decolonial movement for anti-imperial freedom inaugurates a gesture toward a revised global intercultural understanding and coexistence that dissolves the cyclical nature of Empire. This must come, Sylvan argues, from outside of Europe's 'civilização-padrăo.' Empire's field of meaning must be reconsidered, beginning with the scenes of writing that it consistently and systemically negated.

It is this decolonial ethics that one finds operating in Sylvan's poetry of the 1970 s and ' 80 . The poetic medium arguably allowed him to develop his theses in ways that the prose medium and its political surveillance in $1960 \mathrm{~s}$ Portugal did not allow. While he openly denounces European colonialism in O Racismo na Europa e a Paz no Mundo, Sylvan once again appears to be much more ambivalent on the matter in Comunismo e Conceito de Nação em África ['Communism and the Concept of Nation in Africa'] of 1969. While the focus of Comunismo is his opposition to the adoption of Marxist-Leninist political and economic doctrines by anti-colonial movements, Sylvan concludes with a defense of Portugal's narrative of a multiracial transcontinental community. He argues that Portugal was able to successfully transcend colonialism into nationhood, sublating a web of colonies into a transcontinental nation by way of a 'fenomenologia cultural [...] possibilitada com o miscigenamento' ['cultural phenomenology (...) made possible by way of miscegenation'] (Comunismo 90). 
While he defines colonialism as an imbalanced cultural and political structure based on clearly demarcated human taxonomies, Portugal, in Sylvan's opinion, transcended such a structure 'pelo pensamento, pelo amor e pela erótica' ['through philosophy, through love, and through erotics'] (Comunismo 90). Sylvan thus restates the heart of Freyre's conceptualization of Portuguese colonial endeavor. He credits António Salazar, the Portuguese dictator at the time of writing, ${ }^{3}$ for promoting a cultural phenomenology that reinscribed intercultural colonial contact into a supposedly horizontal multiracial transcontinental collective. Moreover, he supports African nations' struggle for political autonomy, while arguing that 'para que sejam livres ficaram a dever aos portugueses o seu caminho primeiro' ['to become free, they owe much to the Portuguese for opening this path'] (Comunismo 85 ) and that without the Portuguese multiracial model, 'também os outros povos, colónias, não poderiam prever-se em condições de Nação' [other peoples, colonies, would not possess the conditions necessary for a Nation' (Comunismo 97).

Despite misrecognizing Portugal's late imperial narrative as a model for an egalitarian cultural exchange and coexistence, Sylvan's critique of communism as a problematic political ideology for African nationhood and national autonomy furthers his dialogical approach to intercultural ethics and epistemology. His argument against the implementation of a strict Marxist-Leninist state is grounded in an understanding that its view of History and class struggle is particular to a European industrial capitalist reality that is not easily translatable to African colonial societies. This is particularly the case of what he understands as the foundational binary operating at the core of Marxist History - that of bourgeois subject versus worker/producer. The Marxist-Leninist political structure that stems from here does not, therefore, adequately account for the realities of rural peasants and intra-ethnic politics. In this regard, Sylvan sees the communist model as yet another form of epistemic violence stemming from Europe. Most interestingly, he takes issue with the teleological nature of the Marxist view of History, namely its implied fixing of meaning. It is here that Sylvan expresses himself as a sort of pre-Derridean deconstructionist - arguing against a hold on meaning that implies a center/margin dichotomy barring emergent scenes of writing.

Although he does not adequately flesh out how non-European anti-colonial and anti-capitalist struggles grappled with Marxism, reformulating it and

3 Although Comunismo e Conceito de Nação em África was only published in 1969, Sylvan completed it in 1967, when Salazar was still head of state, prior to passing the baton to Marcello Caetano in 1968 due to health concerns. 
effectively de-Westernizing it, ${ }^{4}$ Sylvan nonetheless reveals the theoretical foundations of his intercultural ethics vis-à-vis colonial politics. For him, the fixing of meaning, whether colonialist or Soviet communist, always implies a center with claims to authority and notions of origin, along with the privilege to articulate the terms of the relationship between the phantasmatic center and its margins. This quest against centrality can be found at work in his poetry of the 1970 s and '8os.

Despite his failure to openly, consistently, and thoroughly condemn the Portuguese state's narrative of a pluri-continental nation, Sylvan's cultural thought nonetheless reveals a steady stance against discourses of inequality and marginalization. His greatest political shortcoming, though, was not recognizing these discourses in the last decades of the Portuguese imperial project. Publicly opposing the state's narrative while residing in the metropolis may not have been an option at the height of the Estado Novo's censorship and its secret police tyranny. Despite his public support of the Estado Novo in this period, the ethical standards to which Sylvan held the Estado Novo's narrative and the avant la lettre theoretical exploration of European colonial discourse warrants critical attention. Even at the level of the state, Sylvan's writings are fraught with ambiguity, one that can be read as walking the tightrope of censorship, the fine line between freedom and imprisonment. He lauds António de Oliveira Salazar - the ideological embodiment of the state - while also calling for a decentralization of the state in relation to the life of the pluri-racial community; arguing that the latter must be in a constant state of intercultural flux.

During the peak of his essayist production, the 1960s, Sylvan occupied an inevitably ambiguous position among metropolitan cultural elites, especially as a Timorese intellectual working in imperial Europe. His exile and transcontinental identity arguably played a role in his questioning of the center/margin dichotomy through which European imperial maps operated. In the Estado Novo narrative of late imperial Portuguese colonialism one that rhetorically diluted (without ever erasing) the centrality of the metropolis, Sylvan found a political expression of his own intercultural ideals. His poetry in the following decades, in the last years of the Estado Novo and after its demise, arguably offered him a politically safer platform through which to grapple with imperial power and its global field of meaning. In doing so, he became not only one of the founding voices in the formation of a Timorese literature written in Portuguese, but also provided a

4 For more on the reformulation of Marxist theory in Third World struggles, see Robert J. C. Young's introduction to the second edition of White Mythologies (2004 $1-31)$. 
map toward a critical scene of writing that negotiates Timorese experiences in the turbulent past.

The poetry of Fernando Sylvan thus reveals a complex working through of East Timor's situation and resituation in imperial narrativization and global politics. In light of East Timor's complex past vis-à-vis local and global forms of power, Sylvan's poetry reflects overlapping openings for nation, diaspora, and post-nation within an articulation of meaning that seeks to elude imperial forms of power, while working with what such power has bestowed upon human relations. Writing against Empire, his poetry seeks a new conceptualization through which to experience a present indelibly shaped by imperial power. In doing so, the elusion of imperial power resides more specifically in imagining global human relations outside of the epistemological framework inherited from European expansion.

Like the work of later Timorese writers and poets, such as Xanana Gusmão, João Aparício, Luís Cardoso, and Ponte Pedrinha, Sylvan's poetry straddles both a delinking of imperial meaning and a gesturing toward a scene of writing in flux. It spans both occupational periods of East Timor's recent history - Portuguese colonialism and Indonesian occupation. As such, it inevitably engages with the philosophical/discursive cores of domination, much like his O Racismo da Europa e a Paz no Mundo. From here, his poetry goes a step further by tracing paths toward self-enunciation vis-à-vis and against discourses of domination fomented by fantasies of sameness and otherness that inform subjectivity within modern power. While O Racismo da Europa is centered on a European subject - an individual interpellated into the field of imperial meaning with the implied end of reproducing said field, Sylvan's poetry is written against the signifiers of colonial otherness and the mechanisms of interpellation into it.

In doing so, moreover, he also inevitably tackles the foundations of imperial sameness working within the system of meaning while questioning its false cohesion. Such engagement targets the dialectical reproduction of each floating piece of the phantasmatic dichotomy by seeking a poetic scene of writing that sidesteps the notions of origin and centrality that inform narratives of imperial supremacy. In response to this theory of a European imperial ego, Sylvan's poetry can be read as containing not necessarily a postcolonial identity, but rather a deliberate scene of writing through which to work out the parameters of postcolonial identity and self-enunciation against Empire and the identitarian possibilities contained therein. In this regard, one can approach the scene of writing operating in his work as a poetics of meta-identity, the lyrical $I$, the voicing force of the poem, as an ontological site through which to reflect on the contours of decolonial identities. In doing so, he stages a right to signify from which time and space 
can be delinked and reimagined. In this sense, Sylvan's poetic decoloniality expresses identity as a battleground through which to engage Empire and to imagine signification beyond and against imperial power.

\section{Identity Unfixed}

The role of poetry as an artistic medium through which to express anti-colonial thought and collective meanings has a profound history within Timorese liberation movements, especially within Fretilin and its precursor, the Associação Social Democrática Timorense [Timorese Social Democratic Association]. Sylvan can thus be considered an early proponent of the poetic genre as political weapon. Anthony Soares, in his study of the emergence of a poetic tradition in East Timor, temporally locates the intensification of poetic production in 'the final years of Portuguese colonial rule and throughout the Indonesian occupation' ('Poets' 134) due to the 'pressing need for political self-expression' ('Poets' 134). Soares highlights the connection between poetry as a mode of formulating anti-colonial collective narratives to the political goals of the Associação Social Democrática and Fretilin in order to foment greater political and cultural literacy as an everyday praxis of liberation. To this end, a national literature is conceived as one in which participation shall not be limited to a small cultural elite. Rather, the promotion of reading and writing becomes, for Fretilin, a vehicle for political and cultural participation within the framework of nation, itself the political vehicle for postcolonial collective autonomy. The focus on literacy is undoubtedly logocentric, and especially problematic in its promotion of Portuguese (spoken by a small minority) as the national language, as Soares also points out: 'this view of the value of a national literature is at once liberating and limiting' ('Identity' 83 ). Several poets and writers, including Sylvan, have nonetheless taken on the ambiguous task of decentering the written word through the written medium.

Soares goes on to point out the subsequent limitations of directing literary work 'towards a single purpose, potentially devaluing any creative impulse that seeks to explore other areas suggestive of dissonant voices reading from a different political manual' ('Identity' 83). Sylvan's poetry, as we shall see, takes poetry as a political medium beyond many of the limits Soares pinpoints. His poetic œuvre, in other words, gestures toward greater forms of liberation beyond nation, locale, and logos, thus taking the later conception of Timorese poetry to new levels: 'a Poesia de Libertação é rica de aspiraçóes humanas justas e profundas. Nela, o poeta abstrai-se e subtrai-se dos seus próprios interesses para se identificar com os do seu Povo' ['Liberation Poetry is rich in just and profound aspirations. In it, the 
poet abstracts and subtracts himself from his own interests to identify with those of his People'] (Timor-Leste 5).

Sylvan published his first two collections of poetry in 1942, but took a hiatus from poetry that lasted more than two decades, publishing his next collection in 1965: 7 Poemas de Timor ['7 Poems of Timor']. The temporal proximity of the publication of 7 Poemas de Timor and Racismo da Europa e a Paz no Mundo possibly accounts for the former building upon the latter, or rather the former offering a subaltern experience of the latter while eluding Empire's signifying process. The very order of the collection's short poems follows the poetic mission of displacing notions of origin and centrality that are at the core of Empire's function of defining and ascribing meaning. Similarly, the collection problematizes Empire's fantasy of a fixed scene of writing - or, to use Walter Mignolo's term, the 'zero point' - as 'the site of observation from which the epistemic colonial differences and the epistemic imperial differences are mapped out' (Darker Side 80).

The collection begins with 'Navio' ['Vessel'], which begins with the enunciation of a very particular geographical location before separating from the locale:

Tata-Mailau

É o pico-avô da minha Ilha.

Subi muitas vezes aos seus três mil metros.

E foi no seu alto

Que meu sonho-menino construiu um navio.

Antes,

Ninguém tinha compreendido

Que a ilha

Não era terra isolada pelo mar. (7 Poemas 7)

[Tata-Mailau

is the great peak of my island

I climbed its three thousand meters many times

And it was at its high point

That my child-dream built a ship

Before,

No one had understood

That the island

Was not a piece of land isolated by the sea.] 
The first two stanzas seem to imply a locale of origin from which a trans-spatial journey ensues - Tata Mailau, also referred to as Mount Ramelau, is the highest point of East Timor. For Sylvan, it seems to suggest a primordial site of interpretation, the place from which the world begins to become knowable, as does the viewer/interpreter's place within it. In the same poetic motion, he is also inscribing a particularly East Timorese place from which the global is understood through the particular signifiers that compose the Tetum language. The term 'pico-avô' ['grandfather peak'] is the literal Portuguese translation of the Tetum for highest peak, tata mailau - tata mai meaning 'grandfather' and lau signifying 'mountain.' Like the langue of Empire, 5 Tetum's collection of signifiers suggests an earth made knowable through metaphors, using the known to grasp and integrate the unknown. It is, therefore, from local knowledge that the decolonial global journey begins.

The final stanza inaugurates a brand of newness in terms of articulating an ontological and geo-cultural site in relation to a global politics shaped by Empire. It is a newness that is inevitably twofold vis-à-vis both an imperial spatial understanding produced by global power and a local narrativization of life in the then colony. The utterance 'no one had understood' emphasizes the emergence of a particular scene of writing from which a different global and intercultural narrative may arise. Such a narrative would offer a new mode of understanding time and space, and with it the radical possibility of a shift in existing fields of meaning.

The poem, and the collection as a whole, arguably begins to put such a possibility into action. From the signified place of the island, the rewriting of it begins. Therefore, if there is to be a notion of origin in the collection, it is one that is perpetually decentered and affected by the ensuing signification that takes place. The ending of the state of isolation indicated in the final line leaves the island - as point of departure - open to resignification, in this case at the hands of Sylvan's gaze of exile. The articulation of a nascent scene of writing vis-à-vis Empire is thus conducted by way of a global journey, somewhat parallel to that of Sylvan's own experience as a colonial exile in the metropolis.

The next poem in the collection builds further upon this journey - on trans-spatial movement serving as metaphor and metonymy of a decolonial meta-identity. The poem is tellingly titled 'Rota' ['Route'] and seems to pick up where 'Navio' left off:

5 I have argued elsewhere that Empire, as a system of differences, is formed through a metaphoric process (Silva, Subjectivity 70-77). 
Não sei se o mar tem voz

Mas a sua voz

Desde pequeno me falava lento.

[...]

Foi ele que me disse

Que havia Espaço e Tempo.

E comecei a viajar sem medo da viagem.

E nunca mais parei

Com medo da paragem. (7 Poemas 9)

[I do not know if the sea has a voice

But its voice

Since I was a child spoke to me slowly.

(...)

It was the sea that told me

There was Time and Space.

And so I began traveling without fear of the journey.

And so I never paused

With fear of the stop.]

The poetic ubiquity of the sea in Sylvan's work, and this collection in particular, posits it as the metaphoric means of traveling through and resignifying time and space, as 'Rota' indicates. The title itself is a term with significant colonial historical weight in Portuguese, reverting back to Portugal's early modern imperial glory of the so-called 'Discoveries.' To this day, the term is a fundamental part of a Portuguese imperial narrative, evoking images of early imperial maps laying out the routes taken by Portuguese ships connecting markets, natural resources, commodities, and, of course, bodies. In homage to Portugal's imperial past, for instance, Adidas named the soccer ball used during the 2004 European Football Championships hosted by Portugal 'Roteiro,' the map of routes. In his reading of fifteenth- and sixteenth-century roteiros, Luís Madureira underscores their functional and symbolic importance as an 'attempt to codify and stabilize both nautical knowledge and the boundaries of Portugal's maritime dominion' (Imaginary 34).

The sea itself, as an aesthetic trope, is also deeply imbricated in imperial cultural production, ranging from poetry to cartography. This is the case, for instance, in Joseph Conrad's Heart of Darkness (1899), when Marlow expresses 
his childhood curiosity for spaces represented in maps. In the context of Portuguese imperial expansion, Luís Vaz de Camóes's epic Os Lusíadas [The Lusiads] (1572), which mythologizes Vasco da Gama's voyage into the Indian Ocean, construes the sea as a site of imperial glory, as well as of perilous obstacles such as the Adamastor, the overcoming of which contributes to the poetic grandeur of Portuguese endeavor. In a later poetic epic of a different sort, the modernist Mensagem [Message] (1934) of Portuguese poet Fernando Pessoa, the sea occupies a central location in Pessoa's reinscription of Portuguese imperial history toward the goal of a national revival. Pessoa's collection effectively recanonized the figures and symbols of Portugal's imperial past, especially as the poem's historical reformulation was quickly embraced by the nascent Estado Novo regime in Portugal as the nationalist text par excellence.

These imperial deployments of the sea as trope make Sylvan's use of it all the more important for his project vis-à-vis Empire and its re-narrativizing of imperial terminologies, reappropriating it as a means through which to unite subaltern experiences of imperialism across geographies. The sea as trope is thus newly infused with symbolic value, a sign taken from Empire's order of knowledge, meaning, and desire, and placed into an emergent terrain of decolonial cultural meaning. Rather than imperially articulating a collection of spaces connected by and subsumed into imperial desire, the sea becomes part of a counter-narrative - not of a necessarily different past, but a different version of the imperial past told from a scene of writing that has been silenced to some degree. As such, this also implies a shift in content between narratives. For instance, while violence and excess were ambiguously both celebrated by and elided from imperial narratives, they are brought to the forefront in potentially decolonial reconfigurations of the past and present. This shift in content would subsequently bring forth a different subject to be interpellated into decolonial sign-systems and reordered desire.

It is arguably with these historicizing implications in mind that Sylvan deploys the sea trope/sign, reclaiming it from Empire's field of meaning, adding a decolonial layer to its palimpsest by enunciating his own route as a gendered, racialized, colonized subject interpellated into Empire. It is by way of the sea, a route through it, that both his body and the colony can enact a transition from existing within Empire as a product of knowledge to problematizing Empire by inscribing meaning. This meaning, though, more specifically in the realm of identity, offers a fissuring vis-à-vis Empire's desire for reproduction. It is at the level of the subject-as-inscriber that Empire's field of meaning is perpetuated. For the racialized/colonized subject, the performance of identity, particularly the inscription of the ego within the 
existing symbolic realm of Empire, implies psychic and significational parameters different from those of the colonist subject, for instance. For the sake of Empire's homeostatic balance, colonized identities must be performed in a way that renders the colonized subject knowable to Empire's gaze and surveillance.

It is through the metaphoric journey of identity, in conjunction with the actual journey of exile, that the lyrical I pursues its ultimate poetic goal: the quest for untranslatability. This implies, for Sylvan, inaugurating a knowing subject that persistently forecloses the possibility of becoming a knowable object within Empire. In the process, Sylvan's writing subject must snag the translating of time and space away from the imperial ego pointed out in O Racismo da Europa e Paz no Mundo, thus inaugurating an identity that is untranslatable.

As Cixous and Clément's text excerpted in Chapter 2 points out, Empire is founded upon translating bodies into meaning, the absolute Other into otherness: the reduction of a 'person' to a 'nobody' to the position of 'other' (71). The translation to which I refer here regarding imperial signification is not the transfer of the same (or at least as similar as possible) signified from the signifier in one language to a signifier in another. Imperial translation, rather, refers to the significational operation by which imperial inscription - travel writing, early modern natural sciences, contemporary political discourses, etc. - shifts physical entities as well as actions into Empire's field of meaning. This is 'translation' more in the sense of the Portuguese or Spanish false cognate trasladar, meaning to move, transfer, or change. In Heideggerian terms, this is the epistemological shift of phenomena from earth to world, transferring the unknown into knowable otherness, undertaken by the subject/being, in this case the imperial ego. Through this process of imperial translation, bodies, spaces, and matter become part of Empire, stripped of their own sense of selfhood; the now othered body having its desire and ego foreclosed from Empire's narrative of time and space.

In this regard, the journey of the lyrical voice/writing subject away from origin into a flux of identity reveals not only a right to signify that is staged, but also a mode by which selfhood may elude its translation into otherness. In order to avoid imperial translation, the emerging decolonial identity must, as 'Rota' suggests, travel 'without fear of the journey' while avoiding stoppages and fixities. The 'fear of stops' underscores the need for constant resignification; that is, the persistent manipulation of significational postponement. A core aspect of such postponement, and larger quest for untranslatability is the elision of centrality, an apparent attempt at erasing its trace. If we read 'Rota' as a continuation of 'Navio,' we can identify, in 
the former, a physical departure from an enunciated origin in the latter. In articulating a meta-identity in constant flux, the departure from the origin also implies its displacement from a privileged place of centrality. Origin, therefore, is merely a point of departure and ceases to be the central signifier to which proceeding meaning refers.

The relationship between center/origin and play, which Derrida ascribes to the history of the West and its structuralist discourses, 'is in fact the concept of a fundamental immobility and a reassuring certitude, which itself is beyond the reach of play' (Writing 279). The center is, in other words, as a phantasmatic 'certitude,' 'paradoxically, within the structure and outside it' (279; emphasis original). History, for Derrida, always a significational operation, implies an origin or end (arche or telos) that 'may always be reawakened or whose end may always be anticipated in the form of a presence' (279). The privilege of the central signifier lies is in its ability to elude play and postponement, thus reinforcing presence through its implied marginalization of meaning outside the center.

A centerless meta-identity thus forecloses the psychic foundation of imperial interpellation. It renders impossible the hailing of the subject into the realm of meaning through a historicized ideal ego - a text that becomes an image of totality for the interpellated subject. The ideal ego is, for the imperialized subject/identity, the primordial center of the imperial field of meaning. It is the crystallization of an entire discursive plane into one image through which the subject is enjoined to reproduce said signifying field. The erasure of origin, or the point of origin within meaning, implies, therefore, a persistent erasure and reinscription, or at the very least a reordering, of the entire realm of meaning. Subsequently, the concept of an ideal ego, as an inaugurating moment of the subject, is rendered null. This would thus imply a global intercultural politics in which resignifications are in constant and overlapping intermingling predicated on an elided relationship between self and other due to the erasure of centrality.

The repercussions of Sylvan's untranslatable meta-identity would be twofold: the inauguration of postcolonial identities that do not attempt to grip reality through a rhetoric of origin and phantasmatic authenticity, and the foreclosure of imperial reification through a consistently centerless entity that can therefore not be made knowable through Empire's epistemological reliance on the articulation of centrality. Empire's system of differences, how earth is rendered and organized into world, is, as Sylvan seems aware, constructed through fantasies of centrality (i.e. the imperial ego/archetypal foundational I) that enunciate a core of sameness around which overlapping spectrums of otherness are at play. As Derrida never ceases to remind us, it is through a core of signified centrality that Western presence is consistently 
articulated through historicity. What Sylvan proposes through his poetic meta-identity is a decolonial subject embedded in a centerless, and thus shifting, system of meaning; a system that, in its undeniable utopianism, dovetails with and even surpasses his ideal view of the Portuguese 'pluri-racial community' in his 1962 book.

In his treatise on decolonial approaches to Empire, Mignolo argues for displacing the Cartesian dictum of Reason - 'I think, therefore I am' - with 'I think where I am,' as 'one basic epistemic principle that legitimizes all ways of thinking and de-legitimizes the pretense of a singular and particular epistemology, geo-historical and bio-graphically located, to be universal' (Darker Side 81). Sylvan, I would argue, goes a step further in his decolonial expression, arguing for a 'where' that is, itself, in flux as global power's flows of capital, ideas, and people is also counter-enunciated by the subject in transit. In doing so, Sylvan also enacts Mignolo's decolonial mission - 'not rejecting Western epistemic contributions to the world. On the contrary, it implies appropriating its contributions in order to de-chain them from their imperial designs' (Darker Side 82). A centerless scene of writing in flux through a field of meaning that is also devoid of a center would inevitably reformulate Western epistemic contributions while displacing any notions of Western centrality which such contributions may imply. In this regard, Sylvan offers a quotidian praxis of decoloniality through identity as an epistemological and meaning-producing function in opposition to centrality.

\section{Postnation against Empire}

This praxis and quest for an untranslatable meta-identity against Empire can also be found in Sylvan's poetry after 7 Poemas de Timor, in different incarnations with varying political implications. His next poetic endeavor garnered significant international attention - the poem Mensagem do Terceiro Mundo ['Message from the Third World'] of 1971. Translated into several languages, it was first published in recognition of the United Nations' declaration of 1971 as the International Year for Action to Combat Racism and Racial Prejudice. Sylvan here situates the poetic voice/scene of writing within a particular collective - the Third World.

The centerless scene of writing, however, allows for a movement between and through different existing collectives, communities, and categories that inform global meanings. In doing so, the narrativization of time and space can never be fixed in one such category of subjective existence in the world impacted by imperial power. A movement through categories, or 'overlapping territories and intertwined histories' to borrow Benita Parry's terms (336-61), perpetually resignifies such categories as well as the larger 
field of meaning in which they may be embedded or against which they struggle. The constant quest for untranslatability, of which Mensagem do Terceiro Mundo is an example, implies a rethinking of what Rey Chow calls 'dominant conceptualizations' (25). In the case of East Timor, such conceptualizations, especially postcolonial nationhood, have largely failed in the realm of political autonomy, ultimately compromising the lives of its inhabitants.

Sylvan's movement away from nation (one that is increasingly ambivalent as he constructs his ouvre) has much to do with its political impossibilities historically beginning with the establishment of colonial power on non-European land. Both the formation of the colony and the transition to nation are violently informed by transnational events and currents of power, bodies, and capital. As many a theorist - political, literary, or otherwise - has stressed in different ways, the postcolonial nation in the strictly geopolitical sense has become an instrument of Empire. Partha Chatterjee's famous warning regarding nationalist projects immediately comes to mind: postcolonial nationhood often implies a 'representational structure [that] corresponds to the very structure of power nationalist thought seeks to repudiate' (38). Decades prior to Chatterjee's observation, Amílcar Cabral shared a similar sentiment referring specifically to global political and economic constraints in his theory of imperialism, notably that colonialism establishes the conditions for neocolonialism. Furthermore, the impact of imperialism (whether through colonialism or neocolonialism) 'on the historical process of the dominated people is paralysis, stagnation' (Cabral 128).

The postcolonial nation, in the ruins of colonialism and in inevitable transition into neocolonialism, is thus always already a post-nation in the international political and economic realm. The fomentation of a specifically national realm of meaning that informs national subjectivity is naturally impacted by Empire's continued webs of power and influence. It is this tension between the formation of a national ethos against Empire's field of meaning and the imposition of a national narrative marginalizing ethnic minorities that has constituted an ongoing debate in the realm of postcolonial studies, ethnic studies, diaspora studies, and cultural theory in general. Edward Said arguably brought the argument to the forefront of cultural thought, positing nationalism as a necessary tool against Empire while also underscoring the pitfalls of discourses of essence that often undergird notions of national identity. In this regard, nationalism is to be transcended. Homi K. Bhabha notably elaborates on Said's take regarding nationalism and national culture, underscoring the hybridity at the core of any culture and cultural identity. Benita Parry finds Said's position to 
be an 'equivocation on the necessity of inscribing cultural identity before it can be transcended, of working through attachments in order to emerge beyond them' (346). For Parry, there appears to be an irreconcilable fissure between 'conserving specific structures of communal subjectivity invented by dominating peoples, and that which conceptualizes the subject as split, unfixed and disseminated' (346).

Stuart Hall, working ambivalently against the grain of Said and Bhabha, offers a defense of 'cultural identity' in terms of one shared culture, a sort of collective 'one true self' that 'continues to be a very powerful and creative force in emergent forms of representation amongst hitherto marginalised peoples' ('Cultural Identity and Diaspora' 223). Hall nonetheless recognizes "the impossibility of "identity" in its full, unified meaning. In this regard, Hall seems to straddle the same line as Said, between nation and post-nation, or the larger critique of identitarian essences. Hall thus asks the ultimately central question: 'Is it possible, acknowledging the discourse of self-reflexivity, to constitute a politics in the recognition of the necessarily fictional nature of the modern self, and the necessary arbitrariness of the closure around the imaginary communities in relation to which we are constantly in the process of becoming "selves"?' ('Minimal Selves' 45; emphasis original). In posing such a question, he gestures toward his larger theoretical argument regarding the project of self and its enunciation in time and space, which seems starkly aligned with Said:

One is aware of the degree to which nationalism was/is constituted as one of those major poles or terrains of articulation of the self. I think it is very important the way in which some people now (and I think particularly of the colonized subject) begin to reach for a new conception of ethnicity as a kind of counter to the old discourses of nationalism or national identity. ('Minimal Selves' 46)

In the final excerpt, Hall appears to suggest a theory of identity in the postcolonial moment that resonates with Sylvan's play and flux of identity. The 'necessarily fictional nature' of identity, echoing Lacan's 'fictional direction' of the imago and ego, allows for shifts in collective identities based on the exigencies of the present.

The poetic movement in Sylvan's ouvre from the spatial signifier/local conception of the 'grandfather peak' to the transnational conception of the Third World, speaks to the 'reaching' for a new conception, one based on constructing links of resistance through the same transnational means through which Empire has been enacted and solidified. Sylvan's meta-identity/decolonial scene of writing finds its practice by way of 
'overlapping terrains' that offer intersecting signifying chains of resistance. Hall concludes his essay 'Minimal Selves' by reminding us 'every identity is placed, positioned, in a culture, a language, a history [...]. But it is not necessarily armoured-placed against other identities. It is not tied to fixed, permanent, unalterable oppositions' (46). In a similar vein, Sylvan's meta-identity seems to be poetically performed and inscribed through the shared experiences of a multitude of identities. Sylvan would perhaps thus pluralize Hall's statement as 'every identity is placed, positioned, in unfixed cultures, languages, and histories.' The category 'Third World' subsumes, of course, a plethora of subject-positions across race, class, gender, sexuality, (dis)ability, age, ethnicity, and language. On the spectrum of power and subalternity, the term Third World has come to refer to varying experiences of subalternity and marginalization vis-à-vis the concentration of power, privilege, and capital.

Sylvan's poetic project reveals an awareness that each system of categorization does not imply one rigid mode of identity. Identity, rather, is situated across and through the intersections of these categories. ${ }^{6}$ At the same time, these are transnational categories in the signifying field of Empire that inform where identity is situated at the national level. The globality of Empire thus demands a critical centerless inscription of identity that expresses itself against Empire by way of trans-local intersectionality. As such, anti-imperial movements have seldom been driven by solely national forces - the documented collaboration of Frantz Fanon, Amílcar Cabral, Guevara, Malcom X, Fidel Castro, and Mao Zedong in the political arena constitutes perhaps the most resonant examples from the tumultuous post-World War II era. More than common experiences of subalternity, the enunciation of 'Third World' evokes a form of consciousness and anti-imperial conceptualization that offered a scene of writing against Empire. The placement of Sylvan's poetic meta-identity into the title Mensagem do Terceiro Mundo reveals an urgency to move through different anti-imperial conceptualizations in order to delink Empire's significational and political edifice. These are not only overlapping terrains but also intersecting signifying chains of resistance.

In the poem Mensagem do Terceiro Mundo, there is no written mark of Timorese identity, but as a colonized space and collection of residents subjected to the reproduction of imperial power, it is a decentered presence. The poetic meta-identity speaks through the name of an existing decolonial scene of writing - the Third World - in order to partake in a reordering of

6 Chapter 7 of this volume offers a more in-depth exploration of intersectionality vis-à-vis decoloniality. 
imperial historicity. As a decentered scene of writing, the meta-identity finds in the Third World conceptualization a mode of inscription through which to carry out a reordering of an existing system of differences regarding time and space. In this sense, the poem particularly labors to insert the 'Third World' - an imperially originated term of colonial 'underdeveloped' otherness, now as a decolonial site of enunciation - into the existing imperial, First World narrative of History:

Năo tenhas medo de confessar que me sugaste o sangue

E engravataste chagas no meu corpo

E me tiraste o mar do peixe e o sal do mar

E a água pura e a terra boa

E levantaste a cruz contra os meus deuses

E me calasse nas palavras que eu pensava.

Não tenhas medo de confessar que te inventasse mau

Nas torturas em milhóes de mim

E que me cavas só o chão que recusavas

E o fruto que te amargava

E o trabalho que não querias

E menos da metade do alfabeto.

Náo tenhas medo de confessar o esforço

De silenciar os meus batuques

E de apagar as queimadas e as fogueiras

E desvendar os segredos e os mistérios

E destruir todos os meus jogos

E também os cantares dos meus avós.

Não tenhas medo, amigo, que te não odeio.

Foi essa a minha história e a tua história.

E eu sobrevivi

Para construir estradas e cidades a teu lado

E inventar fábricas e Ciência,

Que o mundo não pode ser feito só por ti. (non. pag.)

[Do not be afraid to confess that you sucked my blood And inflicted wounds on my body

And removed the sea from the fish and the salt from the sea

And the pure water and good land

And raised the cross against my gods

And silenced the words I thought. 
Do not be afraid to confess that you invented yourself wrongly In the torture of millions of me And that you only gave me the ground you refused And the bitter fruit And the labor you did not want And less than half the alphabet.

Do not be afraid to confess your efforts In silencing my drums And in extinguishing my fires And unraveling secrets and mysteries And destroying all of my games And also the songs of my grandparents.

Do not be afraid, friend, for I do not hate you.

That was my history and your history.

And I survived.

In order to build roads and cities by your side And create factories and Science, Because the world cannot be built by you alone.]

The first line of each of the first three stanzas - 'Do not be afraid to confess' - seems to target imperial narrativization, a message from a decolonial scene of writing to the imperial scene of historicization. In this regard, 'Do not be afraid to confess' can be read as 'do not be afraid to inscribe' - that is, do not be afraid to inscribe the violence carried out, but which was historicized imperially in a mode divorced from the experiences of those who received such violence. As such, the poetic voice at work here targets specifically what is left out from imperial historicization. The events to which the poem refers (religious imposition, destruction of non-European modes of knowledge, silencing of the colonized, forced labor, theft of land, and genocide) are, moreover, acts of historicization in themselves. All are acts through which the colonized becomes a text and an amalgam of subject-positions within Empire. As acts of narrativization that inscribe meaning, they are practices of imperial jouissance - acts that follow Empire's desire for reproduction.

In this vein, the decolonial spirit of the poem evokes Žižek's argument that jouissance is not historical, but the very act of historicization: it is 'the non-historical kernel of the process of historicization' (Plague 49). In other words, jouissance is not what is written, but the writing itself - the act of inscription that produces the phantasm of historical presence and the field of meaning in which it is embedded. By enjoining the First World to confess, Sylvan's poetic voice is demanding that imperial scenes of writing 
integrate their mode of writing the signifying field into the field itself. As with all forms of jouissance according to Lacanian theory, 'I cannot simply integrate it into my universe, there is always a gulf separating me from it' (Žižek, Plague 49). For Lacan and Žižek, jouissance, such as the violent acts of signification at the core of Empire, implies an 'excessively intense encounter [that] affects the subject's ability to assume the full ontological weight of his world-experience' (Plague 48). Obliging the imperial subject to confront jouisssance, the violence of meaning-production, by placing it into Empire's realm of meaning thus constitutes an attempt to destabilize Empire's subject-constituting function. ${ }^{7}$

In this regard, the poem puts into practice what Fanon called for at the end of Wretched of the Earth: 'The Third World is today facing Europe as one colossal mass whose project must be to try and solve the problems this Europe was incapable of finding answers to' (238). For Fanon, most notably, this project must imply 'a new start, develop a new way of thinking, and endeavor to create a new man' (239). The final stanza of Sylvan's poem dialogues, in many ways, with Fanon's declaration - Europe or the First World, Empire at large in its global impact, is to be survived, overcome, and improved. This would imply, of course, a breaking of Empire's monological scene of writing, gesturing toward a dialogical and decentered post-Empire worlding or field of meaning.

Importantly, the utopian objective is left for the poem's final lines. The core of the poem is reserved for the articulation of a decolonial scene of writing composed of overlapping terrains that constitute the Third World. If Fanon, like Amílcar Cabral, called for the creation of a 'new man' - itself a decolonial scene of writing, Sylvan's poem and decolonial meta-identity add further nuance to such an endeavor. As we have explored, Sylvan's decolonial philosophy crucially avoids centrality and notions of essence. The decolonial scene of writing would thus have no temporal or spatial beginning or end, in addition to eluding Empire's monologism. To this end, the poetic voice does not seek to locate a voice within the larger Third World conceptualization, but opens the conception to its inherent pluralities and experiences, especially those of suffering, by evoking 'as torturas em milhóes de mim' ['the torturing of millions of me'].

The poetic meta-identity, without a specified beginning or telos, can thus speak through established scenes of writing, such as the Third World, while expressing them in the plural. Third World is itself an overlapping of experiences of Empire. As such, it functions in the poem not only as a

7 Chapter 4 includes further discussion on the role of jouissance in Empire and how its denunciation offers decolonial possibilities. 
decolonial conceptualization of the global, but also embodies the centerless spirit of Sylvan's project. The poetic voice captures Third World scenes of writing through which the meta-identity speaks as 'millions of me' - the singular voice is always already in the plural, thus negating any attempt at monologism, by conjuring up the particularity of each of those millions of experiences without bestowing notions of centrality to any of them. This in itself represents another departure from imperial signification what Bhabha calls the 'metonymy of presence' (171), through which the stereotype is constructed. In colonial discourse's taking of 'one' to signify 'all,' it articulates a central core of otherness - a set of signifiers that serves to represent a particular category of otherness into which subalterns are interpellated. By evoking a decolonial meta-identity, a poetic identity and voice that opens possibilities of meaning-production for decentered/ marginalized identities, Sylvan does not cease to point out, overtly or implicitly, Empire's significational dependency on centrality.

The movement of Sylvan's poetic meta-identity and interconnected quest for untranslatability finds yet another layer in his 1981 collection, Cantogrito Maubere: 7 Novos Poemas de Timor ['Song-cry Maubere: 7 New Poems on Timor']. Published during the period of Indonesian occupation, backed by the US and Australian governments, the title refers to a national struggle for liberation against an imperially funded and sustained invasion. Nonetheless, such a specific struggle is conveyed, in some of its poems, through geopolitically unspecific imagery pertaining to the larger fight against Empire. This is the case with 'Passagem do Testemunho' ['Passing the Testimony']:

Há quinhentos anos que gritamos contra a violência das grilhetas e do chicote nos nossos corpos e almas dos nossos avós.

Há quinhentos anos que gritamos porque foi só isso que nos ensinaram nas nossas vidas dos nossos avós.

Mas na contra-fraternidade da violência aprendemos a gritar liberdade construção independência para as nossas vidas dos nossos netos. (17)

[For five hundred years we have cried out against the violence of the fetter and the whip on our bodies and on the souls of our grandparents. 
For five hundred years we have cried out

because that is all they taught us

in our lives of our grandparents.

But in the counter-fraternity of violence

we learned to cry freedom construction independence

for our lives of our grandchildren.]

Where in Mensagem do Terceiro Mundo a larger imagined terrain of collective experience within Empire is deployed while also integrating myriad global subject-positions and particularly historically grounded identities without a center, 'Passagem do Testemunho' offers the opposite. While it is part of a collection of poetry with a nationally charged title, it nonetheless speaks to other historical experiences of Empire. Therefore, even when East Timor's present appears to be central, it is still decentered in favor of a spatially and temporally unspecific identity that conveys a field of meaning where 'the millions of me' can speak and signify. The space of articulation in which this meta-identity operates is one that emerges from Empire's atrocities and signifying chain.

Moreover, the geographically and temporally undefined scene of writing of the poem intertwines the Timorese struggle against Empire with centuries of anti-imperial struggle from around the globe. Beyond trans-spatial connections of anti-imperial endeavor, the poem also undoes temporal divisions (pertaining to generations as well as categories of past, present, future) in terms of theorizing such a struggle. The final lines of both the second and third stanzas are the most potent examples of this ('in our lives of our grandparents'). The suffering of the present generation is inseparable from the suffering of the previous, while the resistance of the present generation will be inseparable from that of the next. The current collective conceptualizations and overlapping terrains also intermingle with those of the future. These are not to be thought of as separate, rather suffering and resistance are not to be firmly located in temporal bounds. In this regard, Sylvan urges us to think of decoloniality as always already in tension against Empire from its very emergence.

\section{Conclusion}

Throughout Sylvan's work explored here, a case can be made that in his deployment of overlapping terrains, a notion of centrality is at work; namely subaltern experiences used by the poetic scene of writing to summon non-dominant conceptualizations. It is, in other words, the subaltern 
experience that enables such a movement. Within the movement through the overlapping terrains, however, there is an integral awareness that subalternity is not one experience, but an amalgamation of different experiences conditioned by overlapping discourses of race, gender, sexuality, disability, class, and place. In this regard, the movement and speaking with subalternity also annul any notion of centrality and authenticity that may arise therein. The meta-identity in constant mutation serves, furthermore, to underscore that within the amalgamation of experiences, none of these is ever fixed. The avoidance of centrality at the level of constructing emerging terrains, communities, or collectivities is mirrored by the individual meta-identity's elusion of authenticity within subalternity.

Regarding decolonial identity politics, Sylvan evokes Paul Gilroy's fundamental argument in The Black Atlantic against the recovery of 'hermetically sealed and culturally absolute racial traditions that would be content forever to invoke the premodern as the anti-modern. It is proposed here above all as a means to figure the inescapability and legitimate value of mutation, hybridity, and intermixture en route to better theories of racism' (223). The articulation of a fixed authentic subaltern experience would result in a centrality that compromised the ultimate goal of Sylvan's poetic meta-identity: a decolonial untranslatability. Sylvan's poetry, as a theorization and exploration of identity within and against Empire's field of meaning, brings forth a poetic voice representing an experiment in identity, speaking, inscribing itself, and reordering the realm of meaning through which it moves toward a politics of untranslatability. This would safeguard a wider participation in signifying processes while not allowing meaning to become fixed. 


\section{Untranslatable Subalternity and Historicizing Empire's Enjoyment in Luís Cardoso's Requiem para o Navegador Solitário} ollowing Portuguese decolonization and during the decades of Indonesian occupation, a new generation of East Timorese writers emerged seeking to formulate and grapple with cultural meanings revolving around the nation's postcolonial political and economic strife. While the twenty-first century saw the end of Indonesian occupation, which had initially been supported by the United States and Australia, the nation's political and economic autonomy continues to be undermined by the historically fomented relationships of dependency upon Western powers, particularly Australia.

In conveying meaning in literary form vis-à-vis the forces of contemporary global power inflicted upon life in East Timor, writers have, in different measures, looked to a revised politics of untranslatability in the construction of protagonists, narrators, and broader articulations of global reality. Like Fernando Sylvan, many have used the trope of trans-spatial movement in order to elaborate a scene of writing that is itself in strategic flux, barring the subject from becoming a fixable object in the web of Empire's field of meaning and knowledge. For instance, novelist Ponte Pedrinha's (pen name of Henrique Borges) most impactful novel, Andanças de um Timorense ['Wanderings of a Timorese'] (1998), embodies precisely this. One can argue, however, that no writer tied to the literature of East Timor, at least that written in Portuguese, has taken such a trope and the project of untranslatability to further levels of creativity than contemporary novelist Luís Cardoso.

Born in 1958 in the East Timorese village of Calaico, Cardoso was raised speaking Tetun-Prasa (also known as Tetun Dili), a creolized form of the Austronesian language Tetum, spoken primarily in the Belu Regency of West Timor and over the border into East Timor. Tetun-Prasa's creolization is, of course, a result of Portuguese colonial presence and it is one of 
the nation's two official languages alongside Portuguese. Cardoso learned the latter through colonial primary and secondary education. Following Portuguese decolonization, he emigrated to Lisbon, where he earned a university degree in agronomy while also exploring his interest in writing. Since the publication of his first novel, Crónica de Uma Travessia - A Época do Ai-Dik-Funam [The Crossing] in 1997, he has become the most celebrated contemporary East Timorese writer. There are, naturally, deep political and cultural implications to such a status, starting with the role of the former imperial metropolis as center of mechanical reproduction and canonization of literature from former colonies. Cardoso's choice to write in Portuguese, but also to deploy numerous Tetun-Prasa expressions, has undoubtedly enabled his work to find a metropolitan readership (regardless of intention) seeking a cultural product that teeters between similarity through language, Western notions of literary excellence, and 'exotic' linguistic innovation. As Timothy Brennan points out regarding Western readership of non-Western literatures, the latter 'bridge the literary world's Manichaean spaces,' feeding an 'attraction to writing that is aesthetically "like us"' (9).

Despite the possible meanings which Cardoso's works have taken on through the canonical agency of metropolitan bourgeois readership - itself an inevitable by-product of Empire and global cultural consumption - his fiction nonetheless articulates subjects grappling with the realm of imperial historicity and the power relations embedded therein. This would itself be symptomatic of a writer whose nation of birth, with which he continues to identify, has found itself at the mercy and born out of such imperial power relations. Isabel Moutinho has categorized Ponte Pedrinha and Luís Cardoso as diasporic writers, arguing that both formulate protagonists whose sense of East Timorese identity is fundamentally fragmented, fraught with seeming paradoxes (359). We can, though, go even further in exploring the political repercussions of such fragmentation in the current moment of global power. Cardoso's central characters and narrators are, like him, in flux through spaces and positions of power, privilege, and capital. It is through this flux that we can better examine the subjective movement toward postcolonial untranslatability.

In his first novel, Crónica de Uma Travessia, for instance, the semiautobiographical narrator, an anti-colonialist exile in Lisbon, retells the story of his colonized yet colonialist father. Like Cardoso himself, the narrator leaves a marginalized district of East Timor (specifically the island of Ataúro) to pursue a university education in Lisbon. Moutinho's analysis of Cardoso's novels centers on notions of diaspora and exile as subjective and psychic deficits. As such, she focuses on perpetual displacement as the marker of the absence of a totalized 'national' identity. Similarly, in 
exploring exilic identities in East Timorese literary production, Teresa Cunha posits exile as an 'experiência de ressignificação de identidade' ['experience of identitarian resignification'] (142). Such a revision represents a transformative 'potencialidade para a sociedade timorense' ['potentiality for Timorese society'] (Cunha 142). Following Sylvan's rethinking of movement and its decolonial possibilities, we can go in the opposite direction by arguing that it is the absence of a fantasized core of identity that affords the narrator of Crónica de Uma Travessia his critique of his father's political existence and his place within Empire. Tellingly, it is the narrator's father who obliges him to study in the metropolis; he had trained as a nurse, believing that acquiring a professional education was the best way to serve the Portuguese flag.

The goal of the novel, I would venture to argue, is not so much to trace or question the parameters of an East Timorese identity. After all, Cardoso seems only too aware of his privileged place as a metropoliseducated exile to propose a model of national identity, or even to identify as East Timorese in the same ways that most of the population would. $\mathrm{He}$ makes this a fundamental part of the narrator's journey in Crónica de Uma Travessia. Upon returning to East Timor, 'tive de fazer a minha autocrítica perante o representante pelo meu passado burguês, decadente e com prática contra-revolucionária' ['I had to perform my own self-criticism in front of the representative for my own bourgeois, decadent, and counter-revolutionary past'] (Crónica de Uma Travessia 133). This offers an interesting internal critique of Cardoso's larger role as postcolonial and metropolis-educated writer, seemingly distancing him from any pretention of speaking for the postcolony. Instead, his work offers interrogations as to how a postcolonial subject can grapple with colonial discourse and the life of imperial power up to the present; or, as Adriana Martins reflects on Cardoso's æuvre, it addresses 'colonialism as a system and its consequences to [sic] the configuration of identity experienced by [his] protagonists' (4).

Beyond any claim to, or reflection on, national identity, Crónica de Uma Travessia stages a postcolonial inscription of the past, the possibility of which arises through the father's loss of memory. The father, as colonial subject and vessel of colonial discourse, carrying out Empire's prerogatives and field of meaning, is emptied by amnesia. The narrator thus takes on the task of historicizing the father. In re-narrativizing the father, he is able to simultaneously reorder Empire's signifying chain. The narrator, in other words, takes charge of establishing the relationship between his father and Empire - the one that is ultimately rendered to the reader. The father, once subject/producer of imperial meaning, is now object of postcolonial inscription. 
Throughout Cardoso's $\propto u v r e$, there is a concern with the possibilities of postcolonial and subaltern historicization. A central problem confronted by many of his narrators pertains to reinscribing the past, (re)signifying the time and space that has led to the present moment from which his narrators speak and write. These moments of reinscription do not arise through monumental political shifts in power. Rather, they emerge through fortuitous, or at times bizarre or even magical, circumstances within different moments of Empire, as is the case with the father's amnesia in Crónica de Uma Travessia. The same is true for Cardoso's second novel, Olhos de Coruja Olhos de Gato Bravo ['Owl's Eyes Wild Cat's Eyes'] (2001), and his third, A Última Morte do Coronel Santiago ['The Final Death of Colonel Santiago'] (2003). In the former, Beatriz, a narrator of mixed Timorese, Chinese, and European origin relates the roles which her parents, especially her priest father, played in Empire. This is after she spends 15 years in Lisbon with her father, who blindfolds her after baptism as a consequence of her large owl-like eyes. She then returns to East Timor only to confront various voids in her paternally manipulated life narrative - i.e. the death of her mother, whom she had expected would remove her blindfold, and the unknown that is her homeland after departing at an early age. In A Última Morte do Coronel Santiago, the narrator, following the Australian intervention against Japanese forces on the island during World War II, tells the story of the titular colonel, a colonial Portuguese military official.

Equally important to the role of historicization in Cardoso's fiction are the historicizers themselves, the diasporic scenes of writing that offer alternative narratives of Empire and the problematic figures embedded therein. The fact that such scenes of writing emerge within Empire, rather than as a clear interruption of it, is particularly central to his construction of narrators. Temporally located within Empire, it is no surprise then that historicization 'remains the operative strategy or, more properly, the method of the postcolonial in so far as it is a way of conceptualizing history from the present - from the vantage point of where we are "now"' (Abeysekara 506). This points to a larger theoretical issue confronting the discourses of postcoloniality, as Ananda Abeysekara notes: 'one cannot historicize the past from the past; one can only historicize it from and in the present. Thus historicization is caught up in the metaphysics of transcending the present' (506). We can, moreover, view historicization in Cardoso's works through Walter Mignolo's decolonial prism. Historicization, Mignolo would argue, contains a strong pedagogical function. In this vein, one can connect delinking (explored here in previous chapters) to what Mignolo refers to in a project cowritten with Madina Tlostanova as 'unlearning.' Unlearning for Mignolo and Tlostanova reformulates, in many ways, the act of transcending 
into rethinking the present, and subsequently the subject, as emerging in the 'colonial matrix of power' (2). Postcolonial historicization, for them, would target specifically the epistemological life of Empire - the realm of imperial knowledge formation pertaining to bodies, land, and commodities. Such a focus on imperial knowledge implies a concern with both the inscription of imperial meaning and the site from which it is inscribed - the formation of the imperial West as it signifies global time and space into a narrative, History.

There is in Cardoso's fiction a laboring toward a scene of writing that grapples with the colonial matrix of power, similar to what we have seen in Mário de Andrade's Macunaima. For Cardoso, this translates into the construction of narrators who are born out of such a matrix but re-evaluate it through the act of narration. We can thus examine how Cardoso frames and performs the relationship between a postcolonial scene of writing and the movement toward decolonial historicization in his fourth and perhaps most nuanced novel, Requiem para o Navegador Solitário ['Requiem for the Solitary Sailor'] (2007).

Set in the early 1940 s as Portuguese-administered East Timor braced itself for a Japanese invasion during World War II, the novel's narrator is Catarina, a young woman born in Batavia, in the Dutch East Indies (present-day Jakarta, Indonesia), whose father is Chinese and whose mother is 'fruto de uma relação entre uma crioula e um governador colonial' ['the fruit of the relationship between a native girl and colonial governor'] (Requiem 13), presumably from Batavia. Catarina's father is the owner of a struggling silk factory in Batavia. One day, he receives a visit from Alberto Sacramento Monteiro, captain of the port of Dili, and born in Goa, 'filho de pai português' ['son of a Portuguese father'] (Requiem 16) and owner of a coffee plantation in the remote village of Manubera in southern East Timor. Monteiro arrives with a business proposition which would make Catarina's father a part owner of Monteiro's coffee business, and Monteiro part owner of her father's silk business in Batavia. To seal the business transaction, Monteiro and Catarina's father arrange for her to marry the Goa-born businessman and port administrator. She subsequently moves to East Timor to join Monteiro, but also to serve as her father's business envoy, in accordance with his financial interests.

\section{Catarina's Ensnarement in Empire}

As narrator, Catarina relates her time in East Timor, beginning with her stay in Dili and the characters circulating within the capital's physical space. She also narrates her rape at the hands of Monteiro, consequently leading to the birth of her child. Following the rape, she wrestles with the 
institutional impossibility of seeing Monteiro, her then fiancé, charged of any crime. Monteiro ultimately leaves her in East Timor with a child and a failed coffee plantation whose crops have been burned in a mysterious case of arson. Part of Catarina's narrative includes her attempt to solve the mystery of the plantation's destruction and to salvage her father's business endeavor in East Timor.

A central aspect of the novel that sets it apart from Cardoso's earlier works concerns the narrator's relationship with East Timor as cultural and political space. The narrator is an individual not overtly preoccupied with negotiating an exilic identity with a point of origin, and so East Timorese space appears first and foremost as a dizzying conjunction of imperial actors and forces. Carlos Henrique Lucas Lima, in exploring the novel's “"transcontinentalidade" como contribuição teórica e política' ["transcontinentality" as a theoretical and political contribution'] (2), posits Dili as 'um local de exilados, degredados e de toda a sorte de comerciantes de distintas nacionalidades' ['a locale of exiled individuals, those banished from the metropolis, and an assortment of merchants of different nationalities'] (3).

The temporal setting in itself evokes myriad political and economic phenomena that afflicted Southeast Asia and the South Pacific: the final decades of European occupation (Dutch colonial presence would effectively end as a consequence of the war) and the imminent Japanese invasion of East Timor anteceded by a pre-emptive occupation by a Dutch and Australian coalition. These looming events threaten to interrupt the everyday life of what in the novel appears to be a colony on the distant fringes of the Portuguese maritime empire where Portuguese, British, Dutch, and Chinese economic interests are pursued by mysterious characters who are also looking to forward their own individual interests.

In addition to the Goa-born Alberto, other important characters whose diegetic existence speaks to the chaotic modus operandi of local colonial power include Indian Jones, described as a Malabar adventurer working as driver, bodyguard, and hitman for Portuguese port administrators. Within this cast of characters, one also finds Rodolfo Marques da Costa, manager of the Hotel Salazar in Dili, native of the Algarve town of Silves, and part-time Arabist who studies the life and literary work of Muhammed Ibn Abbad al-Mu'tamid, the last ruler of the taifa of Seville, al-Andalus. Marques da Costa is, perhaps more importantly, a political exile, expelled from the metropolis by the Salazar regime for his anarchist views. Drawing on Edward Said's reflection on experiences of exile, Carlos Henrique Lucas Lima argues that 'é a partir de fora, do exílio, que a ideia da nação portuguesa é construída por Marques da Costa' ['it is from outside, from exile, that Marques da Costa constructs the idea of the Portuguese nation'] (6; emphasis original). 
The way in which Marques da Costa performs this construction, or rather, this particular historicization of Portugal is especially interesting, and is yet another example of how Luís Cardoso engenders characters that produce meaning against Western historicity. His interest in the Islamic political and cultural presence in the Iberian Peninsula goes beyond the superficial syncretistic narratives of Portuguese nationhood, such as those of Gilberto Freyre and Teixeira de Pascoaes which posited the origins of 'Portugueseness' as the result of Semitic and Aryan cultural mingling. What is often left out of such narratives is the brutal erasure of the former through centuries of persecution and the dominant historicization of Iberia as a Christian, and subsequently European, geo-cultural space. This erasure, and intertwined othering of Semitic signifiers, is central to the fantasy of a white Christian Europe as the racial and spiritual underpinnings of Westernness. ${ }^{1}$ Such a version of Europe whose narrative of modernity - scientific and political - owes much to Semitic thought, whose ideas have been whitewashed and historically separated from their former temporalities. From the experience of exile, Marques da Costa gestures against these forms of erasure through his study of al-Mu'tamid, and proposes a conceptualization of Iberia that reclaims Islamic presence while also questioning the dominant global mappings of East and West, and the racial consequences thereof.

What Catarina thus finds in East Timor is arguably more than the intersecting of exilic identities, but also that of global narratives, both imperial and decolonial, in contact and flux. Another example of this is the character central to the unraveling of the coffee plantation. The enigmatic Malisera, also known as Adriano da Fonseca, a Timorese leader and anti-colonial rebel, resides in Manumera, the location of the plantation. The colonial authorities accuse him of burning the crops. He is seemingly a mythic figure venerated by the Dili community with which he interacts: 'todos os maltratados iam ter com Malisera para se queixarem das autoridades, civis e militares, dos régulos e dos sipaios, e também das calamidades naturais' ['the mistreated all sought Malisera to complain of the authorities, civil and military, of the chief or native soldiers, and also of natural disasters'] (Requiem 123). Catarina is one of the few non-Timorese people to have been in direct contact with him. As she learns, the true perpetrators of the plantation's destruction were

1 The place of the Iberian Peninsula within this fantasy has itself been a point of contention among cultural and political elites that have set out to establish the parameters of Europe. William Ripley's famous The Races of Europe (1899) and Carleton Coon's second edition of the same title quickly come to mind. Roberto Dainotto's Europe (in Theory) (2007) offers an in-depth exploration of the fantasy of Europe vis-à-vis both the rest of the world and the margins of Europe. 
the Portuguese colonial authorities (carried out specifically by Indian Jones) seeking to maintain a monopoly on coffee production.

Catarina is thus ensnared in a complex interweaving of inter-imperial desires (Doyle 2014) - European, Chinese, Japanese, and Australian - in addition to the desires of particular characters which may or may not dovetail with those of Empire. These include those of her father, a member of the Chinese bourgeoisie in Batavia, and also, more complexly, the anti-colonial desire of Malisera. The novel's narration grapples precisely with the different ways in which Catarina is placed into the realm of meaning where the aforementioned desires and imperial interests are manifest. Within this signifying field she, as a woman of Chinese and Indonesian descent, is often the object of different male gazes, as well as the imperial masculine gaze residing behind Empire's epistemological function. East Timorese space, as a chaotic intermingling of different individuals, is subsequently an intersecting area of a plethora of subject-positions within Empire. In her narration, Catarina carefully considers (or at the very least, cleverly alludes to) the ways in which she is signified by the different subject-positions that comprise East Timorese space, in itself a microcosm of Empire.

In this regard, she is able to historicize, through her own narration, how she is signified, beginning with her first encounter with Monteiro. In doing so, she also signifies other identities in the text, and how these affirm themselves in colonial space. In this sense, Catarina's narration operates through a particular critical distance (but also stemming from visceral proximity) from the inscribed actions, and simultaneous closer examination of how identity interacts with Empire at the crossroads of race, national origin, gender, and class. She narrates the imperial signifying field by way of the subject-positions that operate within and reproduce it. At the same time, Catarina carries out such a narration of Empire by playing with different elements that have served to reproduce hegemonies within this realm of meaning, namely the interplay of occulting and presenting information. As particular examples will make clear, she brings forth topics, largely through brief digressions, that problematize imperial narratives of masculine and European superiority and historical agency. In this vein, we can discuss the possibilities of the novel presenting a de-masculinized/decolonial act of historicization.

It is important to begin with the very fact that Catarina is able to historicize. This speaks to a reality in which privilege and subalternity are not fixed oppositions. Part of her privilege is seen through her ability to sidestep subalternity in different moments and contexts and gain access to meaning production. Privilege and subalternity exist, therefore, in a continuum rather than as a dichotomy. As such, Catarina effectively shifts to and from privilege and subalternity depending on the bodies (placed within 
power) with which she interacts. The trans-spatial reach of Empire manifests itself in how subjects residing within the imperial power spectrum shift position and inscribe themselves according to the signified bodies and signifiers that make up a particular space within Empire's coordinates. This seems to be a common prerogative among many of the characters with whom Catarina comes in contact - ranging from the aforementioned Goa-born administrators and Malabar adventurers to metropolitan Portuguese prisoners sent to East Timor to reproduce a Portuguese colonial presence.

The lack of a consistent diegetic presence of East Timorese characters, aside from Malisera, points toward a circle of local power from which natives are barred, and their marginalization from such power is implied throughout most of the novel until the reader begins to better understand the life of Malisera. Moreover, this implied marginalization functions $v i s-\grave{a}$-vis the dominant and more visible characters as an amalgamated, unspecified otherness, an imperially signified background against which foreigners can inscribe their subjective presence within Empire. Such a diegetic marginalization serves to underscore the dialectics of subalternity and power/privilege, reproduced by the ability of particular characters to perform power in the colonial terrain.

Catarina herself is an example of this. When she lived with her parents in Batavia as a young girl, she could not speak in the presence of her father. The same is true in the presence of Monteiro upon their first encounter. Her body is at the mercy of the historicizing processes of the imperial matrix of power. She recalls her presence in this particular moment as resembling that of - and indeed being confused with - a jade ornament in the form a cat:

O visitante, durante todo o tempo em que esteve em nossa casa, náo tirou os olhos nem de mim nem de uma peça de jade, que representava uma gata. Provavelmente, o seu interesse pelo objecto servia de cobertura para outra peça amarela que náo era de pedra, mas sim de carne e osso e representava uma menina chinesa com pretensóes culturais exóticas. [...]

Antes de sair, olhando na minha direcção, perguntou pelo nome da peça que o meu pai disse chamar-se Catarina. (Requiem 15)

[The visitor never removed his gaze from me nor from a jade ornament representing a cat the entire time he was in our house. Perhaps his interest in the object was a cover for his interest in another yellow piece that was not made of stone, but of flesh and bone and represented a Chinese girl with exotic cultural pretentions. (...)

Before he left, looking in my direction, he asked the name of the piece my father said calls herself Catarina.] 
This is a particularly complex reflection on Catarina's subjective experience, namely her placement within power and the forces at work behind identity. She exists, first and foremost, as a signifier manipulated by the paternalism of Empire: the 'piece my father said calls herself Catarina.' The verbosity of this clause is certainly no fluke. Through the process of subjectivation, Catarina is not only signified by her father, she is taught to signify herself paternally, through the discourse of the father - calling herself Catarina. Her act of historicization that is the text of her narration thus begins with her journey of identity, her placement within dominant historicization. The excerpt above adds a notable layer to the Lacanian conception of ego formation in the mirror stage, notably the specular image of identity as a 'fictional direction' (Écrits 76). Catarina points out the signifying forces behind such a fiction - an image engendered for the reproduction of a particular symbolic order. In the exchange between Monteiro and Catarina's father, the name/signifier 'Catarina' is merely the surface of the symbol/ object that characterizes her early life, as an inter-masculine object of exchange, within the realm of imperial power. The consequences of her narrativization as object for power reaches its apex when she is raped by Monteiro, her fiancé.

The incident leads her to question a particular narrative that had guided her romantic desire up until that point - that of Prince Charming ['príncipe encantado']. She gradually comes to grasp the story as a part of her entrapment within the matrix of power. The tale of the Prince Charming who would appear at some point of her life ultimately dovetails with her subjectivation, teaching her to desire, as part of both compulsory heterosexuality and conformation to masculine agency. The tale, furthermore, becomes an instrument through which she is taught to desire masculine agency over meaning, the desire to be signified patriarchally. Moreover, Catarina's account of her own infatuation with a fictitious Prince Charming - the tale through which she framed Monteiro's initial presence in her life - obliges us to understand this fable as one of patriarchy's obscurantist tales of its own power and the epistemic violence of masculinity over its phantasmatic feminine other. The overlapping of the Prince Charming tale with Catarina's rape forces the reader to connect the masculine historical agency at the core of the tale with patriarchy's very real and, in this case, physical and institutionalized violence.

Catarina, moreover, adds various layers of colonial meaning to the myth of Prince Charming and its repercussions for her subjective experience within Empire. In a colonial space whose institutions operate patriarchally, thus sanctioning the reproduction of an imperial field of meaning, her racial identity inevitably supplements the patriarchal reification of her body as a 
gendered entity. Aside from finding no justice against her rapist through institutional channels, she is signified in Dili as a nona. ${ }^{2}$ The term is assigned to Catarina by the capital's colonialist social circles when it becomes known that Monteiro was in fact already married to a Portuguese woman. She thus once again becomes a sexual signifier within Empire's realm of meaning, revealing in turn the limits of her social privilege in East Timor. Where male characters are able to inscribe themselves in different ways in the easternmost Portuguese colonial holding, the patriarchal component of Empire implies a persistent signification of Catarina's subjective existence. In this regard, Catarina's historicizing act is most crucially a historicization in confrontation with that of Empire.

Her act of narrativizing the reproduction of Empire leads her to consider not only the colonial signifiers that place her body into Empire, but also some of the everyday praxes of imperial power. Catarina recalls a notable instance of these in the wake of her rape, which impacts her ability to historicize the traumatic experience, especially vis-à-vis the schema of power through which the trauma emerged. In an ambiguous and laconic reference to the rape, Catarina notes: ' $O$ que me aconteceu estava escrito algures num local que não pude, em tempo oportuno, decifrar. Faltou-me um visionário que me tivesse ensinado a ler o meu futuro nos sinais do tempo' ['What happened to me was written someplace that I could not decipher in time. I lacked a visionary who could have taught me to read my future in the signs of the time'] (Requiem 92). Catarina's reflection here posits the rape as an inevitable consequence already written within Empire, where her body is constructed as violable. The tale of Prince Charming, in other words, rendered such a violent event indecipherable to her in her subjectivized place of the other; an ontological site barred from writing and only able to liminally and partially access the textuality of Empire.

In this sense, Catarina seems to reflect on Empire's historicizing function as a series of heterologies, to borrow Michel de Certeau's terminology; that is, as a set of 'discourses on the other' (Writing 3). De Certeau theorizes modern Western history as an 'intelligibility established through a relation with the other' (Writing 3). The other, of course, is just as constructed as the ensuing relation. De Certeau thus expounds on the other as a shifting object within Western heterologies such as historiography, medical knowledge, ethnology, and pedagogy: "it moves (or "progresses") by changing what it makes of its "other" - the Indian, the past, the people, the mad, the child, the Third World' (Writing 3). Catarina's evocation of an indecipherable place speaks to her existence as 'an object that is supposedly written in an unknown

2 See p. 112 for a definition of nona. 
language' (Writing 3), to the 'division between the body of knowledge that utters a discourse and the mute body that nourishes it' (Writing 3 ).

Both Catarina and de Certeau grapple with the modus operandi of Western signification and its organized 'rift between discourse and the body' (Writing 3; emphasis original). It is from this rift that Catarina writes her text, from the site of exclusion from dominant writing. Barred from the indecipherable place of writing, of signifying time and space embodied by local colonial authorities that both keep her under house arrest and produce their own meaning pertaining to her, she takes up her own writing. This, of course, is a writing that is not fully supported by political imperial power, despite her relative clout in the privilege/subalternity spectrum. Like the current limits of postcolonial cultural production and decolonial knowledges imposed by contemporary global power, Catarina's writing will, therefore, not supplant or adequately contest colonial power. Rather, Catarina, we can argue, offers a writing on writing; on the imperial 'relation between a "will to produce history" (a subject of the political operation) and the "environment" (into which is carved a power of decision and action)' (de Certeau, Writing 7). A core component of her historicization concerns examinations of how colonial power is reproduced in East Timor through various signifying processes, whether through written records or sexual acts.

\section{Writing, Resistance, and the Inscription of Jouissance}

Following Monteiro's departure from the post of Dili's port administrator, a new administrator, Geraldo Pinto Pereira, appears at Catarina's place of residence, which she shares with Madalena, a previous lover of Monteiro with whom she too had a child, Esmeralda. Due to her earlier contact with Malisera, seemingly the colonial police's most sought-after individual, Catarina is a person of interest to the colonial authorities and intelligence agents. Like Monteiro before him, Pereira offers Catarina a pet cat, a gesture that expresses sexual interest on the part of the giver. Suspecting that Pereira's interests may be principally political and/or sexually exploitative, Madalena suggests that Catarina invite him for dinner where Madalena would prepare a poisonous fish specifically for him. During the dinner, Catarina initiates a sexual encounter, but not without also tasting some of the fish Pereira was beginning to suspect. She wakes up in the hospital, while Pereira is comatose due to the larger portion of fish ingested.

Through this encounter with Pereira, Catarina finds a sort of redemption; not so much from poisoning the port administrator, but more so from being able to control an interracial sexual encounter from the position of other and, more importantly, to narrativize it. Being left comatose, moreover, 
Pereira is physically unable to carry out his imperial, patriarchal mandate of inscribing the liaison. Within her narrativization of that night, Catarina also captures how Pereira interpreted her body during the encounter, leading her to several digressions regarding how her body had been patriarchally and imperially signified in the past. One passage is particularly illustrative of this. During a flirtatious conversation about Pereira's dream of reaching the Pearl River in South China, Catarina recalls her mother wearing pearl necklaces and her father's (to whom she refers simply as 'the old Chinese man') refusal to allow Catarina to also wear one:

Quem gostava de pérolas era a minha mãe. Para ser precisa devia dizer o meu pai, que se servia dela para exibir a sua rica colecção de pérolas. Os seus inimigos, quando queriam fazer-lhe a vida negra, diziam que um dia cortavam a cabeça à mulher. Ele não se ralava com isso. As verdadeiras escondia-as num cofre secreto.

Nunca andei com nenhum colar de pérolas. O velho chinês dizia que o meu corpo não precisava de outros ornamentos para fazer um homem feliz. Nasci com a justa medida de todas as coisas, as formas distintas e proporcionadas.

- Uma gata de jade

e tirava as medidas ao meu corpo como se fosse um alfaiate. (Requiem 96)

[My mother really liked pearls. To be precise, I should say my father did, as he used her to exhibit his rich collection of pearls. His enemies, when they wished to antagonize him, used to say that one day they would behead his wife. That did not bother him. The real pearls remained hidden in a secret coffer.

I never wore a pearl necklace. The old Chinese man would say that my body did not need any ornament to make a man happy. I was born with just the right amount of everything, a distinctive and well-proportioned body.

- A jade cat

and he would measure my body as if he were a tailor.]

Interestingly, this digression transitions directly back to the actions of Catarina's encounter with Monteiro, the last two lines of the excerpt situated ambiguously between the memory of her father's signification of her body and Pereira's physical contact with it. The penultimate line is a reference to the metaphor evoked by Monteiro in the presence of her father, where her marriage was arranged. The jade cat was the statue/commodity - serving as 
stand-in for Catarina - which Monteiro ambiguously indicated as the object that would seal the business agreement between him and her father.

The use of a commodity as the sign-substitute for the female body points to Catarina's place within the masculine sphere of power, as a reified object of exchange necessary for the reproduction of capital and the existing field of meaning. Luce Irigaray reminds us that:

the society we know, our own culture, is based upon the exchange of women. Without the exchange of women, we are told, we would fall back into the anarchy (?) of the animal kingdom. The passage into the social order, into the symbolic order, into order as such, is assured by the fact that men, or groups of men, circulate women among themselves. (170)

Catarina's passing from father to fiancé embodies Irigaray's understanding of this 'matrix of History, in which man begets man as his own likeness, wives, daughters, and sisters have value only in that they serve as the possibility of, and potential benefit in, relations among men' (171). This rings true for both the exchange of Catarina, from father to husband, and her father's symbolic use of her mother as a vehicle through which to inscribe his identity vis-à-vis the circulation of capital and the inter-masculine competition therein.

The female subject, an object produced/gendered here under the father's supervision, himself an instrument of the symbolic order/Empire's reproduction in his paternal function, is conferred to the would-be husband. This patriarchal transaction is thus centered on an inscription of Catarina, the jade cat. It also reinscribes the masculinity of the transacting parties. Catarina thus seems to add a further element to the exchange of women: the commodity becomes the fantasy - the screen or frame through which her body is signified. In locating the fantasy, Catarina pinpoints the phantasmatic nature of masculine agency and inscription over women. She also foresees and seeks to disable the fantasy through which Pereira attempts to render her body knowable within their sexual encounter. She uses this knowledge of masculine power in her own dealings with Empire, reading Empire by way of how Empire reads her.

The inclusion of the sign-substitute commodity in Catarina's historicization of the sexual encounter with Pereira constitutes an interesting superimposition of temporalities - the masculine historicization of her body is historicized by her in turn, in a new moment. She inscribes a realm of meaning while not disconnecting it from its modes of reproduction. Catarina, in other words, inserts imperial jouissance into her representation of Empire. Following Slavoj Žižek's take on jouissance, the term for the subject's act of signification - ranging from historiography to sexual violence - in 
response to the big Other's (here, Empire's) desire for reproduction, the act of signification in itself must not be historicized. That is: 'jouissance designates the non-historical kernel of the process of historicization' (Žižek, Plague 49). Her narrativization of her time in East Timor pays particular attention to not only the relations of men and power (namely the different port administrators who succeed one another in Dili), but also the levels of jouissance that produce and reproduce this matrix of power.

Returning to Catarina's narration of her night with Pereira, she now refers to Pereira's tactile perusal of her body after she recalls its placement in the masculine economy of desire. The passage develops as if Pereira were reading the body as a signified text:

Passava as mãos pelos meus cabelos, pelo rosto, pelos olhos. Desceu até aos lábios, que espremeu até ficarem rubros, antes de deslizar pelo pescoço e finalmente lançou a âncora junto do meu peito e por lá amainou. Demorava-se nos meus seios enquanto tacteava os mamilos, que ficavam tensos. Como se apalpasse as pérolas debaixo da blusa.

- Tem mão de pirata, capitão

- Todos os ocidentais têm fantasias acerca do oriente

- Qual é a sua, capitão, qual é a sua? (Requiem 96-97)

[He ran his hands through my hair, down my face, over my eyes. He moved down to my lips, which he squeezed until they were bright red, before slipping down my neck and finally anchored himself on my chest, where he settled. He lingered around my breasts while feeling my nipples, which grew tense. As if he were groping the pearls under my blouse.

'You have a pirate's hand, captain.'

'All westerners have fantasies about the Orient.'

'What is yours, captain, what is yours?']

Although Pereira never answers Catarina's question before losing consciousness, he nonetheless reveals the phantasmatic nature of imperial signification and the operation through which he reads the body. It is an imperial fantasy of gendered oriental otherness that makes it knowable to him, and that informs empirical experience. The Western fantasies to which Pereira refers, whatever they may be, intermingle with both the gendering carried out by Catarina's father and the space of masculine exchange in which the female body is inserted. The imperial field of Western meaning has, in other words, already coded 'oriental space' and the bodies that inhabit it. Having read the field of meaning through interpellation, Pereira is equipped with an array of signifiers pertaining to sameness and 
otherness, functioning as a priori screens of interpretation through which to experience time and space.

Žižek argues for an even deeper function of fantasy vis-à-vis the symbolic order of meaning, namely as its 'unacknowledged obscene support simultaneously serv[ing] as a screen against the direct intrusion of the Real' (Plague 64-65). The implications of Pereira's utterance in his exchange with Catarina thus go far beyond his imperial experience of that particular moment. The orientalism of Empire, and more broadly its entire signifying field of sameness and otherness, is undergirded by a repeated phantasmatic operation. The subject gives meaning to experience, and thus staves off the intrusion of the Real (where meaning and power break down), through the existing signifiers of the symbolic. In doing so, the subject simultaneously reproduces this field of meaning, the big Other. As Žižek clarifies in this regard, fantasy is the 'screen concealing the gap, the abyss of the desire of the Other' (Sublime 132). Fantasy, in other words, allows the subject to carry out the desire of the Other, Empire, for its own reproduction and the homeostatic balance of power. Herein lies the jouissance of Empire, the reproduction of its signifying field. Through enjoyment, in the shape of inscribing/performing identity, the subject also enjoys (reproduces meaning) for Empire.

Part of the decolonial potential of Catarina's text thus resides in its relationship with imperial enjoyment sanctioned by the imperial fantasy of otherness. In historicizing jouissance, she is giving meaning to an excess that is too much to be signified into Empire, and thus has no place in the dominant field of meaning. Žižek elaborates: 'Every ideology attaches itself to some kernel of jouissance which, however, retains the status of an ambiguous excess' (Plague 50). Catarina's dealings with the port administrators demonstrate her own placement in relation to imperial jouissance. The fantasy to which Pereira alludes indicates the imperial exchange value attributed to 'oriental' women's bodies. They are a site of jouissance, a phantasmatic other through which the imperial field of meaning and Pereira's place within it as a specularly total subject are simultaneously reconsolidated by way of interracial sex and framed by the imperial orientalist fantasy.

\section{Enjoyment, Masculinity, and the Imperial Superego}

Catarina's exploration of enjoyment and the imperial field of meaning revisits a theoretical discrepancy concerning the psychic existence of the subject, with crucial implications for the subject within Empire. Jouissance, for early Lacan (pre-1960), was intricately tied to the superego, itself an entity he locates as existing within 'the totality of the system of language' (Lacan, Seminar I 102). In this sense, the superego appears to be an inevitable 
by-product of the symbolic order and its incessant demand for reproduction. The superego in traditional Freudian readings appears as an entity of repression, seemingly opposed to the subject's enjoyment. For Lacan, on the other hand, the superego is the voice of the enjoyment afforded to the subject within the symbolic order. It is the superego, in other words, that enjoins the subject to enjoy, as long as the enjoyment serves the balance of the symbolic order - the desire of the big Other.

Throughout his work, Žižek posits the injunction to enjoyment as a postmodern condition in which the subject's relationship with its specular image of totality is based on the fulfillment of pleasures ranging from the sexual to the consumption of commodities. This has long been the case within the imperial symbolic order, especially for the subjectivized masculine subject. The performance of European heteronormative masculinity, such as that of Pereira in Catarina's text, is potentiated by an imperial injunction to enjoy the field of power in which its agency is signified and legitimized. This masculine enjoyment based on the signified bodies and spaces in circulation within Empire ultimately serves the desire of Empire - reproducing its symbolic order and the agency of European heteronormative masculinity therein.

The obscenity of the superego in its injunction for masculine jouissance lies in its opposition to supposed conservative social norms such as heterosexual monogamy and marriage. These are, however, tenuous aspects of the Law in relation to men, although as Adrienne Rich reminds us, marriage nonetheless serves as an operation of compulsory heterosexuality (633). The superego's injunction to enjoy beyond such norms seldom has consequences for men in positions of power backed by patriarchal institutional support. Subsequently, the breaking of the Law by masculine enjoyment constitutes the heteronormative masculine subject's response to the desire of Empire. Herein lies the relationship between the Law and the big Other tied together by the superego. There appears to be a gap between the sometimes superficial laws of the symbolic order of intersubjective relations and the reproduction of this order. The superego marks this gap - the space where broken rules maintain the status quo of power, so long as the rules are broken by those in or serving power.

It is crucial to bear in mind that the symbolic order, especially that of Empire, never emerges spontaneously, but is rather reproduced by way of existing systems of power. In this regard, the superego, existing 'within the symbolic plane of speech' (Lacan, Seminar I 102), speaks for the field of power through which it is rendered. Lacan elaborates on his rethinking of the superego vis-à-vis Freud in his writings, notably tying the emergence of the superego to gaps in the symbolic chain, in the desire of the big Other 
(Écrits: Selection 143), thus leading to distortions of the Law. Herein lies the function of the superego's injunction to enjoy, in the case of the masculine imperial subject.

Any gap in the imperial field of meaning is to be taped over by way of enjoyment, distorting the Law to maintain the integrity of the Other. For Pereira and Monteiro, in other words, the superego as the will-to-enjoy (volonté de jouissance) repeatedly, if not structurally in the case of white European masculinity, distorts the Law (i.e. that of white bourgeois marriage) in order to reproduce the imperial field of racial and sexual meanings and subject-positions therein. This inevitably leads us back to jouissance and fantasy, the latter functioning as the significational screen through which the subject experiences the former in response to the desire of Empire. Reproducing Empire thus always means covering the gaps in the symbolic order. It is no surprise, then, that Lacan explores the centrality of this will-to-enjoy in his theorization of sadism in the essay 'Kant and Sade.' Lacan's fundamental argument here is that the sadistic act of the subject works for the balance of the symbolic order, for the big Other. The superego thus operates in relation to the gaps in the symbolic order by making the subject the 'instrument of jouissance' (Écrits 654) for the big Other. In this regard, the superego is a central aspect of the symbolic realm, enjoining the enjoyment of the subject necessary for the enjoyment of the Other - its reproduction and homeostatic balance.

Enjoyment and the superego are not universal entities and series of demands for all subject-positions residing in the imperial field of meaning. The content of the superego injunction is, in other words, contingent upon the demands of Empire for each subjectivation. In the imperial realm, the superego's injunction will inevitably vary by subjectivizing imperial categories such as race, gender, class, and sexuality. Firstly, the signifying field of Empire, at least within Cardoso's novel, does not provide the quantity of phantasmatic texts and possibilities of enjoyment for non-European, non-masculine, non-heteronormative subjects that it offers Pereira and Monteiro in Requiem para o Navegador Solitário. In this regard, if the feminine subject within the imperial symbolic realm truly has no superego, or at least a weaker one, as Freud argued, it is not because women lack guilt, as he suggested. Rather, in a patriarchally established field of sexual, racial, and social meaning, the injunction to reproduce (through enjoyment) a symbolic realm where the privilege of European normative masculinity resides applies particularly to the individual interpellated and subjectivized into that privilege. The superego is a psychic function for the Other, it is a product of patriarchal imperial signification, and therefore sanctions enjoyment primarily for those who carry out such signification. 
The superego, after all, enjoins a breaking of the Law, rules and regulations most strictly enforced on disenfranchised others. In other words, for the object of imperial historicization and knowledge, there are fewer gaps in a violently enforced Law, as evidenced by Pereira and Monteiro's known and accepted marital infidelities in comparison with the strict surveillance of Catarina by local authorities, to say nothing of the local collective inscription of her sexuality. For subjective experiences of subalternity, breaking the Law ultimately leads to a punishment that reinforces subalternity. As is well-documented, and tritely represented in cultural production, an adulterous woman almost always suffers a fall in the social hierarchy of power.

Under the guise of such a Law, one finds the market of commodity exchange where women's bodies are located, as theorized by Irigaray; a market guided by the superego injunction for heteronormative masculine enjoyment: 'The possession of a woman is certainly indispensable to man for the reproductive use value that she represents; but what he desires is to have them all. To "accumulate" them, to be able to count off his conquests, seductions, possessions, both sequentially and cumulatively, as measure or standard(s)' (Irigaray 174). The use value of woman as commodity, pointed out here by Irigaray, marks the means by which the masculine subject inscribes himself in Empire; through the accumulation of women, in other words. It is no surprise, then, that both Monteiro and Pereira are married to European women. For Pereira and the masculine imperial subject able to move transnationally and/or trans-colonially, this is a global market spawned by imperial inscription and where women's bodies are attributed use and exchange value based on the signification of racial difference. Colonial space and colonial bodies become interweaved, the latter often standing for the former in the imperial market of masculinity.

Irigaray does not, of course, fail to underscore the inter-masculine tensions played out by masculinity in the market:

Reigning everywhere, although prohibited in practice, hom(m) o-sexuality is played out through the bodies of women, matter, or sign, and heterosexuality has been up to now just an alibi for the smooth workings of man's relations with himself. Whose 'sociocultural endogamy' excludes the participation of that other, so foreign to the social order: woman. [... the social order] does not tolerate marriage with populations that are too far away, too far removed from the prevailing cultural rules. A sociocultural endogamy would thus forbid commerce with women. Men make commerce of them, but they do not enter into exchanges with them. (172; emphasis original) 
We can, moreover, take these relations between men even further, to the level of imperial historicization, namely Empire's masculinist existence. Imperial inscription, emerging and reproducing itself by way of inter-masculine dialectics, points toward the existence of an implied male gaze within Empire's field of meaning. More than providing the phantasmatic material through which women are exchanged and used for and by historical inscription, the signifying field implies a surveying entity that oversees subjectivation and identity performance. Lacan's term for this implied gaze is the 'ego ideal,' the psychic site 'from where we are being observed, from where we look at ourselves so that we appear to ourselves likeable' (Žižek, Sublime 116; emphasis original).

As I have explored regarding Empire (Silva Subjectivity), the ego ideal is created and reproduced concurrently with its larger field of meaning, a product of the dialectics of historical inscription, guided of course by the masculinist forces and agency sanctioned and reproduced within said field of meaning. In this regard, the 'hom(m)o-sexual' sphere of relations between men is fundamentally a relation between the masculine subject and the imperial field of meaning, particularly its masculine gaze. To reaffirm their position within the big Other, responding to its desire, masculine subjects must enjoy for the big Other by way of the phantasmatic support of experience offered by Empire's textuality. In this sense, the imperial field of meaning is constituted and constitutes its subjects' hom(m)o-sexually.

What Catarina's text performs through her tension with imperial male characters is an attempt at historicizing imperial masculine enjoyment and, subsequently, the imperial superego. The superego, in evoking gaps in the Law and how it is not applied universally, is as Žižek clarifies, a 'supplement of obscene unwritten rules' (Plague 11). As such, the superego maintains an ambivalent position in relation to the field of meaning. Citing Lacan, Žižek elaborates on the status of the superego: 'the superego is a Law in so far as it is not integrated into the subject's symbolic universe, in so far as it functions as an incomprehensible, nonsensical, traumatic injunction' (Metastases 20). This status of the superego as not integrated into the symbolic yet, a crucial factor in the subject's social existence within meaning, is unsurprisingly reminiscent of Lacan and Žižek's take on jouissance, the latter pairing enjoyment with narrativization. In other words, the non-integrated status of the superego does not mean it is not a function of the symbolic. Rather, the subject's inability to integrate the superego can be translated as the subject's incapacity to narrativize it.

Joan Copjec furthers this ambiguity by positing the superego vis-à-vis the subject as a series of 'voice-commands' (57) which, despite being 'obscene, is felt "within like a stranger"' (57). For Copjec, 'obscene' comes to indicate 
that which is 'out of scene,' out of the subject's readily accessible field of meaning. In comparison to the Law, therefore, the superego and its always-implied enjoyment is seldom made publicly present. The rules of enjoyment, although sanctioned for the imperial masculine subject through the symbolic field's phantasmatic support, are never part of what we call public knowledge or official rules. Catarina's text offers an intricate example of this psychic/significational ambiguity of the imperial superego through her dealings with different port administrators and colonial functionaries, namely in sexual interactions.

The fantasies to which Pereira refers, allegedly harbored by all Westerners about an imperially constructed Orient, point toward an injunction to enjoyment that we can locate in the superego, thus pinpointing its operation within Empire. In the context of the imperial signifying field where the subject resides, the Law arguably pertains to the official imperial rules of engagement between subject and othered bodies. It is at the level of imperial Law, for instance, that one finds the Manichaean discourses of strict racial compartmentalization, the masculine dominance of particular spaces, and the interdiction of interracial love and sex. These visible, public, or 'on-scene' rules all serve the purpose of responding to the desire of the big Other, and in doing so safeguard imperial European masculine power over historicization.

The symbolic field that is the big Other is, however, more than a set of official rules. It is a field of signified time, space, and bodies where these are objects of imperial knowledge, a set of signifiers that seldom correspond to any positive physical property. As such, the fantasies to which Pereira alludes are always already built into the imperial field of meaning that is produced and reproduced phantasmatically. The official rules of the Law themselves must be followed through this phantasmatic support through which the subject experiences and interacts with othered bodies. Following the rules of racial compartmentalization, for instance, implies an understanding of the other through the meaning with which such a body has been signified - as monstrous, dangerous, virile, sexually deviant, a threat to the normativity of white life, itself a fantasy as well.

Because the field of imperial meaning is greater and more broadly encompassing than the official rules of the Law, the phantasmatic content of the big Other also offers the subject the significational frames through which to break the Law. In other words, the same phantasmatic support for the Law is also that of the superego, both operating in accordance with the desire of the Other. The superego, though, is not simply a consequence of the existence of the Law, somehow coming after it. Rather, the superego runs parallel to it, emerging and making its presence felt simultaneously 
with the Law. Žižek comes to a similar conclusion in attempting to resolve the relationship between the Law and the superego:

The only solution to this deadlock, of course, is to conceive of these two narratives as the two complimentary ideological gestures of resolving/ obfuscating the underlying deadlock which resides in the fact that the Law was smeared, stigmatized, by enjoyment at the very moment of its emergence as the neutral universal formal Law. The very emergence of a pure neutral Law, free of its concrete 'organic' life-world support, gives birth to the obscene superego underside. (Plague 11-12)

As such, the Law and the superego, while appearing to be oppositional, constitute their own dialectic in synchronizing the subject's desire with that of the Other. We can also think of this relationship between Law and superego in terms of Lacan's distinction between pleasure and jouissance in that the former is aligned with the Law and the latter with excess beyond pleasure. As Lacan explains, 'the function of the pleasure principle is, in effect, to lead the subject from signifier to signifier, by generating as many signifiers as are required to maintain at as low a level as possible the tension that regulates the whole functioning of the psychic apparatus' (Seminar VII 119).

The excess beyond the pleasure principle in the case of the masculine imperial subject-position, however, also contributes to the generating of signifiers and the reproduction of meaning - the homeostatic balance of the big Other. A signifying-field whose emergence is predicated on excess toward a phantasmatic other offers a built-in excess of enjoyment beyond its immediate realm of public knowledge. We see this reconciliation of Law and superego, pleasure and jouissance, at work in Pereira. He holds an official position within the colonial administration, enforcing rules of Empire, but he is also guided by the enjoyment implied by the fantasies of sameness and otherness within Empire.

The textuality of the other within the signifying field - the fantasies mentioned above - makes the other an object of official colonial knowledge within the Law, and a site of enjoyment beyond the Law. The heteronormative European masculine subject in Catarina's text is mandated through the body of meaning rendered in both sides of the symbolic realm. We can go as far as to argue that the Law and the superego function in the case of Pereira as interpellating entities, hailing and maintaining the subject in the symbolic by way of a promise of enjoyment through the body of the other - oriental woman, in this case. In this regard, Freud may have been right to situate the superego within the Oedipal complex, as the agency that shifts the subject's desire from the mother to another entity. Even here, there is a level of enjoyment in Freud's elaboration of the superego - one that Lacan 
would later expand. In shifting the desire of the subject, the superego promises future enjoyment; that is, through the phantasmatic support of the signifying field. In this sense, the superego may enunciate the Law's prohibition, but does so by guaranteeing enjoyment later within the desire of the big Other. It is in her flirtation with Pereira that Catarina extracts this promise of enjoyment - one that, as she uncovers, guides Pereira's imperial trans-spatial movement.

\section{Interpellation and Empire's Masculine Subject}

A significant portion of Catarina's text is, in fact, guided by an interest in the interpellation of imperial male subject-positions - how they come to take on their imperial mandates. This is the case not only with port administrators, but also with the titular character: the solitary sailor referred to is Alain Gerbault, a real-life lone sailor who circumnavigated the world and lived a portion of his life in the South Pacific, before dying in Dili. He wrote numerous books on his travels, one of which Catarina read in her youth and mentions throughout her text - A la poursuite du soleil (translated into English as In Quest of the Sun: The Journal of the Firecrest). Fiction and history once again intersect in the text when Catarina recounts learning of the arrival of Gerbault's vessel at the port of Dili, where he seeks medical attention for the malaria that would ultimately kill him. Local colonial authorities summon Catarina to welcome Gerbault and help monitor his illness.

Even before her encounter with him, Catarina interrogates the economy of desire at work behind travel endeavors like those of Gerbault. What we learn through Catarina's questionings are the possibilities of enjoyment afforded by Empire to masculine subjectivity. Sexual enjoyment by way of othered bodies rendered accessible by Empire operates in a similar capacity to the enjoyment of travel, which for Gerbault culminates in his writing and contribution to imperial knowledge. He takes on the enjoyment of travel afforded to European bourgeois men, a level of jouissance by which they fulfill their interpellation, their imperial gendered mandate. Gerbault's voyages embody enjoyment beyond the pleasure principle/Law. Remaining on land would allow him to carry out the imperial mandate in traditional ways (i.e. within metropolitan society) while also retaining his physiological balance. Exceeding the pleasure principle, however, allows him to pursue his interpellation even further, to generate more signifiers conducive to the balance of Empire.

Despite his open criticism of the colonial exploitation of non-European populations, Gerbault's circumnavigation is nonetheless an experiential enjoyment made possible by the existing imperial narrativization of 
time, space, and matter into which he is subjectivized. For Gerbault, this narrativization came in the shape of maps, earlier travel writings, and the realm of imperial knowledge - in addition to spontaneous interpellation. Catarina's text gauges an imperial materialism when noting how Gerbault's writings ultimately become part of and reproduce the signifying field in which he was interpellated.

This is the case of the third port administrator with whom Catarina comes in contact - César Semedo, who is described as having been born in Cabo Verde. Considering his access to higher education in the metropolis and ability to ascend through the administrative ranks, he seems to hail from a family with colonial Portuguese ties. Prior to Gerbault's arrival at the port of Dili, Semedo tells Catarina of his own interpellation into Empire by way of maritime travel, namely through an adolescent chance encounter with Gerbault in Cabo Verde during the latter's circumnavigation. Through the filter of Catarina's narrativization, we learn that Semedo

ainda era finalista do Liceu. Havia a promessa de continuar os estudos na metrópole. A façanha do francês levou-o a decidir entrar na Escola Naval. Tinha o sonho de fazer uma viagem à volta do mundo. Claro que isso náo passou do impulso de um adolescente. Quando se fez marinheiro deixou o romantismo de lado. O mar passou a ser a sua profissão. A rotina fez da sua vida um tédio. Começou a ficar enjoado de andar tanto tempo embarcado. Só queria chegar a qualquer porto para se desforrar do tempo em que tinha ficado fechado numa gaiola de ferro. (Requiem 153)

[was a high school senior at the time. He had the opportunity to further his studies in the metropolis. The feat of the Frenchman guided his decision to enter the Naval Academy. He dreamt of sailing across the world. Of course, such a wish never led to anything more than adolescent impulse. When he became a naval officer, he set aside such romanticism. The sea began to be his profession. The repetitive routine made his life tedious. He grew seasick from spending so much time in ships. He yearned to arrive at any port to make up for the time spent in a steel cage.]

In historicizing Semedo's interpellation into Empire and maritime work, Catarina also points out the dynamic between jouissance and pleasure operating in Semedo's subjectivation. His quest for enjoyment sanctioned by Gerbault's text leads him toward an excess of the Law, which he experiences as painful tedium and persistent nausea. Between jouissance and the fundamental prohibitions of the pleasure principle, however, Semedo is 
offered a balance allowing him to efficiently take on his imperial mandate and adequately respond to Empire's desire. As an interpellated masculine imperial subject, Semedo, like Monteiro and Pereira, is able to move in the interstices between jouissance (superego) and pleasure (Law). It is no surprise that the lives and actions of these three port administrators/masculine imperial subjects constitute much of Catarina's text. Within her own act of historicization, they become her objects of study - from interpellation to enjoyment. It is through their roles as subjects within Empire that she attempts to understand the field of imperial meaning within which she also moves, a field that she attempts to narrativize while she herself is narrativized by and for it.

The dialectics of interpellation pertaining to Gerbault and Semedo reveal, for Catarina, the politics of enjoyment offered by their masculine imperial mandate, an enjoyment she is denied despite her interest in travel engendered by her own reading of Gerbault's narrative. She thus contrasts her predicament with that of Gerbault and other French travelers. Citing Gerbault's statement to her that 'os franceses estão em todo o lado' ['the French are everywhere'] (Requiem 174), she reflects upon the imperial sanctioning of European movement across global space as opposed to the signification that surrounds her own travels:

não era nenhuma mentira. Tinha um na minha presença. Não era nenhum militar e muito menos estava ao serviço dos holandeses. De mim não diziam a mesma coisa. Mostravam alguma desconfiança pelo facto de ter vindo da Batávia. Uma espia. Uma nova Mata-Hari. (Requiem 174)

[it was no lie. I had one in my presence. He was not a military officer and much less at the service of the Dutch. They did not say the same about me. They were suspicious of me due to the fact that I came from Batavia. I was a spy. A new Mata Hari.]

The imperial field provides European masculinity a global passport, while rendering non-masculinity and non-Europeanness knowable by way of existing permutations of otherness.

Catarina's evocation of Mata Hari is particularly relevant here. The famed historical figure known by that stage name (given name Margaretha Geertruida Zelle) and executed by a French firing squad after being presumed a spy for Germany during World War I becomes a signifier within Empire, one into which Catarina is placed by colonial historicizing authorities. Like Catarina, Mata Hari was also a traveling woman, one whose movement across imperially signified space (the Netherlands, Dutch East Indies, France) 
raised the suspicions of English and French port authorities. Catarina thus provides an implicit contrast of signifiers by which masculine and feminine subjects are placed into meaning - Gerbault exists as ideal ego for Semedo while Mata Hari remains a fantasy of gendered otherness by which imperial authorities regulate traveling women's bodies.

\section{Intersectional Historicization}

The historicizing project of Catarina's text is, perhaps due to Empire's complexities, inevitably multifaceted. Carlos Henrique Lucas Lima therefore posits the novel as one that 'procura fundar uma ética da diferença e da diversidade, abandonando o dualismo' ['looks to found an ethics of difference and diversity, abandoning dualities'] (3) tied to Empire. Catarina thus expresses her ordeal in establishing a scene of writing emerging from the intersectionality (studied in more depth in Chapter 7 ) of her subject-position within Empire, while also being ensnared by the imperial field of meaning. Her text, in other words, grapples with being a scene of writing against being written. In this sense, her writing project inaugurates a renewed search for untranslatability vis-à-vis Empire, carried out via a flux through imperially signified space and the signifiers of subject-positions that constitute the imperial signifying field.

In several passages of the text, she looks to sidestep the meaning imposed on her by gesturing toward a place between signifiers of otherness, residing at the intersection of different gendered and racialized forms of imperial otherness. She attempts to use her movement through imperial space and interactions with different subject-positions within Empire to gesture toward untranslatability - an escape from being a knowable object of imperial narrativization. Her writing is thus always a multifarious act writing in order to avoid being written, to elude Empire's translation (again, the verb trasladar) of her from historicizing subject to historicized object.

We can think of this gesture as an example of critical hybridity, utilizing the interminglings of privilege and subalternity that mark her life and movement through the realm of power - bourgeois, woman, 'oriental,' foreigner - in order to inaugurate a site of non-imperial signification. Catarina, moreover, is guided by a search and exploration of the gaps in the imperial symbolic realm of meaning, looking to exploit intersectionality to grab hold of an ontological space between imperial signifiers of otherness. It is no wonder that her text contains several dystopian allusions to a nonexistent time-space not yet signified by forces of power. In narrating her dinner with Pereira, she offers a digression related to the possibility of an existing paradise, ultimately refuting its projection as a place: 
Nunca formulei no meu pensamento que o paraíso pudesse ser projectado num lugar. Seria antes um estado de alma. Já me aconteceu estar num lugar horrível sem que isso fosse um impedimento para me sentir feliz. (Requiem 94)

[I never thought that paradise could be projected onto a particular place. I thought of it rather as a spiritual state. Although I have been in horrific places, I never allowed it to become an obstacle to happiness.]

We can read such a reflection as suggesting there is no locatable escape from the signifiers of power. Rather, the only possibility is to critically engage with existing meaning. This, of course, entails for Catarina a decolonial stance vis-à-vis meaning, a need for delinking that her text carries out in relation to Empire, particularly in terms of the imperial masculine subject and the excesses enacted upon her.

Aside from opening myriad identitarian possibilities through her untranslatable scene of writing, itself a noteworthy political act, Catarina's text aims to destabilize the hegemonic writing and signification that is inflicted upon her. A crucial example of this is her historicization of the interracial sexual encounter with Pereira, a gesture with profound implications vis-à-vis the patriarchally signified narrative of Lusotropicalism, based largely on Gilberto Freyre's (and others') theorization of Portuguese colonialism as a union with the tropics based on love, rather than convenience (Portuguese 46). In doing so, she underscores the phantasmatic content of sameness and otherness that informs interracial relations including the private (sexual) and the public (institutional).

She critically draws the lines from the signification of her body within imperial meaning to her rape at the hands of Alberto Monteiro, the colonial surveillance that surrounds her, the kidnapping of her son, and several other tragedies that mark her time in East Timor. This interrogation as to the politics of desire operating behind the violence she suffers leads her to confront Empire's economy of enjoyment for imperial masculinity. In doing so, we gain a perspective on the place of jouissance in terms of the imperial masculine subject and, more broadly, the relationship between the Law and the superego, between publicly sanctioned rules of pleasure and the obscene unwritten injunctions to enjoy by way of Empire's phantasmatic content. By exploring enjoyment, Catarina renders visible the off-scene, that which is outside of the Law but informs the seen/ on-scene modes of imperial narrativization. It is the off-scene injunction that inflicts the subject's enjoyment upon the phantasmatic other in different forms of violence. 


\section{Conclusion}

In many ways, Catarina's text can be thought of as a writing on writing, bringing forth a critical reflection on and delinking from enjoyment, signification, and imperial power. Catarina thus historicizes a masculine sphere of imperial interpellation, one in which subjects are enunciated to become scenes of writing and producers of meaning, while she is placed into Empire to be their object of knowledge, meaning, and enjoyment. Most importantly, Catarina historicizes the excess of Empire beyond its Law, and subsequently, the frailty of the imperial subject operating at the intersection of the Law and the superego. Her text leads us to think of the superego's operation within Empire as the institutionalization of excess and jouissance necessary for the continuity of Empire and the individual powers of the European masculine subject, the latter always being the assumption of a specular image residing in the signifying field. The excess becomes crucial to the sustained assumption of the image by the subject, which of course constitutes their response to Empire's desire. Sustained subjectivation (i.e. performed identity) guarantees the reproduction of the imperial field of power via excess. In this sense, Catarina envisages Empire's signifying field as a series of written-over voids - from the subject that inflicts violence upon her to the entire symbolic realm and power itself. These are the layers of imperial meaning that are unveiled through her historicization of Western signification. Catarina's text does not simply relate the signifiers of Empire to the reader, but seeks to point out the ways in which such signifiers are reproduced. 


\section{Imperial Cryptonomy: \\ Colonial Specters and Portuguese Exceptionalism in Isabela Figueiredo's Caderno de Memórias Coloniais}

\footnotetext{
The end of formal colonialism in Lusophone African nations (Angola, 1 Cabo Verde, Guinea-Bissau, Mozambique, and São Tomé and Príncipe) ushered in numerous political, societal, and cultural shifts on a transnational spectrum. Portuguese decolonization, following more than a decade of counter-insurgency in Angola, Guinea-Bissau, and Mozambique, and the eventual fall of the right-wing Estado Novo regime, led to the migration of over half a million former colonists to the metropolis. Those who did not see a future outside of the colonial system of power, or feared political turmoil in the postcolony, arrived in Portugal in 1974 and 1975 to find a metropolis also at the beginning of political reconstruction following the Carnation Revolution that ended the Estado Novo. The process of repatriation began with the political designation of former colonists as retornados [returnees], a paradox because many were born in the colonies and had never set foot in Portugal. Angola and Mozambique had been the largest settler colonies of the Portuguese overseas empire. Subsequently, they accounted for the vast majority of retornados, even before they became internationally recognized sovereign nations.

Following their large-scale arrival in Portugal, the term retornado quickly became imbued with social stigma stemming from imperial notions of nationhood and colonial otherness. The depth of this stigma is central in much literary production by or about retornados, reflecting on the interrelated events and periods of colonial settlement, decolonization, and nation-(re)building in Lusophone Africa and Portugal. The introspective and erratic retornado narrators of António Lobo Antunes's O Esplendor de Portugal [The Splendor of Portugal] (1997) comment, often extensively, on their
} 
social standing in post-imperial Portugal, as individuals of compromised whiteness. ${ }^{1}$

On the other hand, the retornados were also perceived by metropolitans as petit bourgeois colonial parasites, as former colonist Isabela Figueiredo recalls:

Quando chegámos a Portugal fomos muito maltratados. Eu era criança e fui muito maltratada pelos meus colegas, pelos meus familiares. Diziam que o meu pai e a minha máe eram ladrões, que tínhamos tido pretos para nos lavarem os pezinhos e o rabinho. E que merecíamos ter perdido tudo. (Coelho non. pag.)

[When we arrived in Portugal we were mistreated. As a child I was mistreated by classmates and relatives. They would say that my mother and father were thieves, that we had blacks to wash our feet and behinds. And that we deserved to lose everything.]

Antunes's novel was arguably one of the first literary treatments of post-imperial Portugal, its present in conjunction with its imperial past, through the lens of the retornados. Since then, numerous works of fiction have been centered on retornado experiences. These range in terms of both thematics and, especially, critical tone. Manuel Arouca's Deixei o Meu Coração em África ['I Left My Heart in Africa'] (2005), Jaime Magalhães's Os Retornados ['The Returnees'] (2008), and Tiago Rebelo's O Último Ano em Luanda ['The Last Year in Luanda'] (2008) are undeniably imbued with heavy doses of colonial nostalgia and imperial adventurism. Meanwhile, works such as Dulce Maria Cardoso's O Retorno ['The Return'] (2011) and Aida Gomes's Os Pretos de Pousaflores ['The Blacks of Pousaflores'] (2011) critically engage, on different levels, the politics of return in terms of racial and cultural identity, in addition to rethinking the imperial past. On an arguably related note, the latter have garnered significant critical interest, while the former have enjoyed bestseller status in the Portuguese literary market.

Another title within this trend that has had a profound impact in the Portuguese public sphere and the collective reimagining of Portugal's colonial past is Isabela Figueiredo's Caderno de Memórias Coloniais ['Journal of Colonial Memories']. Published in 2009, the collection of memoirs began as a series of blog posts by the author titled Novo Mundo [New World] and reflecting on her experience of being raised as a white colonist girl in colonial Mozambique. Figueiredo was born in Lourenço Marques (present-day Maputo) in 1963 , her formative years coinciding with the final decade of

1 This novel will be explored further in the next chapter. 
Portugal's colonial presence in Africa. Her colonial memoirs, comprising 43 of the aforementioned blog posts, relate her experiences of race, gender, and the reproduction of colonial power, as well as the dawn of her insertion into Portuguese society as a retornada in 1975.

Anna M. Klobucka posits the national impact of Caderno in its opposition to the commonly held narrative of amicable relations between Portugal and its colonized peoples, made most famous by Brazilian sociologist/ anthropologist Gilberto Freyre in a series of writings beginning in 1933 . He notably theorized Portuguese love of the tropics to be at the core of an exceptional culturally syncretistic and hybrid civilization which he called 'Lusotropicalism.' Klobucka reads Figueiredo's memoir 'as a particularly forceful counter-cultural statement against the Portuguese and Freyrean tradition of infusing the representations of Lusophone colonialism and postcolonialism with postulations of affect as a centrally operative force' (40). In a similar vein, Patrícia Vieira asserts that Figueiredo's work 'strives to debunk myths associated with Portugal's supposedly benevolent colonialism and present a de-idealized image of the former empire' ('Imperial Remains' 284). Figueiredo accomplishes this by foregrounding 'the violence and falsehood that operated in the colony and in the consciousness of the colonists and the retornados, although she does so with a fiercely confrontational bluntness that has few, if any, equals in the literature of Lusophone postcolonialism' (Klobucka 41).

The bluntness of her stance is evident from the very outset of the collection. The first chapter/blog post critically alludes to Manuel Arouca's Deixei o Meu Coração em África and its participation in propagating the Lusotropical narrative:

Manuel deixou o seu coração em África. Também conheço quem lá tenha deixado dois automóveis ligeiros, um veículo todo-o-terreno, uma carrinha de carga, mais uma camioneta, duas vivendas, três machambas, bem como a conta no Banco Nacional Ultramarino. (Caderno 11)

[Manuel left his heart in Africa. I also know someone who left in Africa two compact vehicles, a sport utility vehicle, a cargo van, a small truck, two townhouses, three pieces of farmland, and also an account in the Overseas National Bank.]

The brief commentary dissects Arouca's titular evocation of love for Africa as nostalgia for the privileges of colonial life founded upon systemic violence and exploitation. Figueiredo's positioning of her text against Arouca's from the beginning speaks to the latter's recycling of Lusotropical thematics. 
One particularly noteworthy portion of Arouca's novel exemplifying its Lusotropical inclinations focuses on the colonial war/anti-colonial struggle in Guinea-Bissau - as the protagonist joins the Portuguese military - but decenters the inherent violence of the confrontation in favor of an interracial love affair between the protagonist and a Fulani woman.

According to Figueiredo, such popularized treatments of Portugal's colonial past ultimately drove her to write and disseminate her experience of such a past. In an interview annexed to the published memoir she states:

sinto que faço o que tinha de ser feito. [...] Estamos sempre a varrer o colonialismo para debaixo do tapete. O que mais gostamos de dizer, quando acusados relativamente ao nosso passado ultramarino, é que 'a nossa colonização foi suave, não teve nada a ver com a dos ingleses, etc.' ('Isto é a sério' 21)

[I feel I am doing what had to be done. (...) We are always sweeping colonialism under the rug. What we most love to say, when accused of our colonial past, is that 'our colonialism was soft, it was nothing like that of the English, etc.'].

Through the medium of memoir, Figueiredo's proposed interruption of metropolitan narratives of the colonial past is undertaken via an overtly autobiographical posture; that is, through a narrating of her placement within ideology, specifically imperial narrativization and local colonial reality. In Joana Pimentel's words, 'Figueiredo recalls her own version of Portuguese colonialism in Mozambique, challenging public memory by commenting on the historical archive of Lusophone postcolonial discourse' (243). The historical period that constitutes Figueiredo's reconstructed past is one of overlapping and conflicting discourses. Born in 1963, her childhood or preadolescence in the late 1960s and early 1970s coincides with the final throes of Portugal's colonial project, along with its exceptionalist rhetoric, and the ongoing struggle for liberation in Mozambique and various parts of the global South, more internationally. In other words, while Portugal's heads of state stubbornly defended a Portuguese presence in Africa on the international stage, pushing the narrative of a transcontinental and multicultural nation composed of overseas provinces and amicable relations between Europeans and Africans, a young subject was being formed by the quotidian race-based violence that informed colonial reality 'on the ground.'

Figueiredo's account of the past detailing numerous variably traumatic experiences ultimately offers a glimpse into the interpellational function of colonialism - how privilege-based colonial society reproduces itself by means of subjectivation. The mainstream Lusotropicalist narrative 
of Portuguese colonialism, and of Portugal as a global entity, functions, moreover, to formulate a national subject/identity whose desire is circuited to the imperial spectrum of power. Herein lies the depth of Figueiredo's text - as Pimentel succinctly puts it - a text that 'challenge[s] the links between identity, language, history and nation' (243). The discourses of race, gender, labor, and capital - central to imperial power, within which identity, language, history, and nation are also couched - ultimately 'hail' (Althusser 174) Figueiredo into Empire's field of meaning. The most salient voice of this field, or the most prominent instrument for its reproduction, is Figueiredo's father. After all,

Quando o meu pai regressou a Portugal trouxe consigo o colonialismo e nunca foi capaz de sair dele. O meu pai era o colonialismo. Portanto, o meu pai era também a injustiça e a violência. Talvez eu não saiba bem, do ponto de vista histórico, o que foi o colonialismo - muito me escapará; mas sei muito bem o que foi o meu pai, o que pensava e dizia, e esse é um conhecimento prático do colonialismo que nenhum historiador pode deter, a menos que tenha vivido a mesma experiência. ('Isto é a sério' 21-22)

[When my father returned to Portugal, he brought colonialism with him and he was never able to escape it. My father was colonialism. Therefore, my father was also injustice and violence. Perhaps I do not know, from a strictly historical point of view, what colonialism was much escapes me - but I know very well what my father was, what he thought and said, and that is practical knowledge of colonialism that no historian could grasp, unless they have lived the same experience as me.]

In tacitly opposing her words to those of historians, Figueiredo ultimately reveals her writing as a way of challenging how the Portuguese colonial past has been historicized. The close and intimate voice that fills the memoir inevitably re-emerges in this interview, making the latter a sort of extension of the former. This is especially the case when reflecting on her father. As the patriarch of a colonist family, the father embodies the intersecting point of whiteness, masculinity, heteronormative notions of sexuality, and control over racialized labor (in their transhistorical imperial constructions). His agency resides, therefore, in the privileged experiences tied to these as separate yet overlapping formations. 


\section{The Father and Ideology}

One of the father's main privileges implies the right to signify and to reproduce imperial signifiers while establishing the relationship between them and his daughter. Jacques Lacan referred to this role within the realm of meaning as the Name-of-the-Father, that which regulates the desire of the subject-offspring. The term, though, is not limited to a biological father or paternal subject. Rather it refers to a 'symbolic function' (Écrits 230) that enforces the law vis-à-vis the subject within ideology, from interpellation on.

More than simply hailing, ideology - in this case, the field of colonial meaning - must trace Figueiredo's desire; that is, her subjective and corporal relationship with colonial space and otherness. While the father in Figueiredo's memoir may represent the crystallization of colonialism's violence and metaphysics, he is not the only source from which colonial meaning is communicated to the narrator. Isabela is placed - as a white woman - into the realm of colonial desire (being taught how to desire in the colonial space - the alphabet of colonial desire), guiding power dynamics in the local realm of the colony and the trans-spatial domain of Empire. This is a process undertaken by and through various members of the colonial intersubjective space, notably those who have also been interpellated as white colonist women. Within the racialized and gendered compartmentalization of colonial space and social life, Isabela's body, genitalia, and actions are traced for her by colonist wives, for instance, in contrast with those of black women: 'Recordo as conversas ouvidas entre mulheres. Eu não tinha idade para entender, pensavam elas [...] porque as esposas de colono, quando se juntavam, falavam das cabras das pretas e da facilidade com que tinham filhos' ['I remember the conversations I heard between women. I was not old enough to understand, they thought (...) because the wives of colonists, when they got together, would talk about the black whores and the ease with which they gave birth'] (Caderno 19).

Fantasies of racial and sexual otherness are central to the narrativization of colonial time, space, and power - one in which interpellated cisgendered female colonists also participate. In fact, Figueiredo's memoir articulates a white female public (micro-)sphere where members inscribe their bodies, as well as those of black women, and their place within local colonial power. It is during this quotidian construction and performance of white colonist womanhood that the young narrator learns of the colonial system of difference and her place therein:

As pretas tinham a cona larga, diziam as mulheres dos brancos, ao domingo à tarde, todas em conversa íntima debaixo do cajueiro largo, 
com o bandulho atafulhado de camarão grelhado, enquanto os maridos saíam para ir dar a sua volta de homens [...]. As pretas tinham a cona larga e essa era explicação para parirem como pariam, de borco, todas viradas para o chão, onde quer que fosse, como os animais. A cona era larga. A das brancas não, era estreita, porque as brancas não eram umas cadelas fáceis, porque à cona sagrada das brancas só lá tinha chegado o marido, e pouco, e com dificuldade, que elas eram estreitas, portanto muito sérias [...]. Limitavam-se ao cumprimento das suas obrigações matrimoniais, sempre com sacrifício, pelo que a fornicação era dolorosa, e evitável, por isso é que os brancos iam à cona das pretas. (Caderno 13)

[Black women had loose cunts, the wives of white men would say on Sunday afternoons, in intimate conversation under the wide cashew tree, their belly filled with grilled shrimp, while the husbands went out on their 'man trips' (...). Black women had loose cunts and that was why they gave birth the way they did, face down, wherever, like animals. Their cunts were loose. White women didn't, it was narrow, because white women were not easy whores, because the sacred white cunt was only accessed by the husband, and very seldom, with much difficulty, since they were narrow, and thus very serious (...). White women would merely fulfill their wifely obligations, always with sacrifice, because fornication was painful, and avoidable, and because of this, white men sought out the cunts of black women.]

This moment ultimately creates a specular image into which Isabela is interpellated - the corporal and subjective place where she is to reside within the colonial field of meaning. In this public space, her body schema and its actions are elaborated as those of a white woman vis-à-vis the fantasy of the black female body. Her body is thus placed into Empire's field of meaning where the sign of black womanhood has been rendered for centuries as simultaneously abject, lascivious, an object of wonder, violable, and an instrument of labor exploitable by white masculinity as a master scene of writing that is also voiced by white women whose identity-sign too has been constructed by this imperial master scene of writing.

One can trace this gendered dialectic of white and non-white womanhood as far back as Pero Vaz de Caminha's Carta do Achamento do Brasil '[Letter on the Discovery of Brasil'] (1500), which details, among other topics, the supposed greater sensuality of Tupi women in comparison to European women:

uma daquelas moças [...] certamente era tão bem feita e tão redonda, e sua vergonha - que ela não tinha! - tão graciosa, que a muitas mulheres 
de nossa terra vendo-lhe tais feições, provocaria vergonha, por não terem as suas como a dela. (165)

[one of those girls (...) was certainly so well-formed and so voluptuous, and her shame - of which she had none! - so charming that many women of our land, seeing such traits, would be ashamed that theirs were not like hers.]

Isabela must, therefore, render her body and perform its corresponding identity according to these long-established yet shifting textualities of racialized womanhood.

The specular image of corporal and subjective totality which the individual confronts and assumes in the Lacanian mirror stage is discursively produced through the power relations of the symbolic realm of intersubjective meaning. For Lacan, this stage marks the transition from specular I to social I (Écrits 79). It is this ideal image - or ideal ego - that 'situates the agency known as the ego, prior to its social determination, in a fictional direction' (Écrits 76). Ever-ambiguous and polysemic in his wording, the 'fictional' nature of the ego speaks to both the un-Real existence of meaning and the ego's inscription within symbolic meaning. In this regard, the moment the ego - nothing 'other than an imaginary function' - is enunciated is also 'the moment the symbolic system appears' (Seminar II 52) to the subject. This instance in which the specular totality of colonial white womanhood is articulated is also a moment in which the symbolic system of colonial power and meaning is presented to Isabela. Nevertheless, Isabela's interpellation as a white cisgendered woman in the colony is both reproduced and complicated throughout her life, thanks in large part to the omniscience of her father.

\section{Crypts and the Colonial Past}

The memoir, as a series of vignettes delving into Figueiredo's experience of the colonial past, autobiographically reflects on her corporal and subjective entrapment, privileges, and perils in the realm of imperial meaning. In this regard, the contents of the book tell the story of a crypt - in the sense of Nicholas Abraham and Maria Torok's term 'cryptonomy' - of both Figueiredo's and Portugal's colonial past. As Abraham and Torok argue, 'the crypt works in the heart of the Ego as a special kind of Unconscious' (80). The crypt itself is a psychic location of fragmented symbols stemming from the trauma of subjectivation. The most omnipresent fragmented symbol of the memoir is inevitably the father - the symbol responsible for consistently policing the narrator's body and intersubjective life within 
colonialism, subsequently embodying colonial power. At the heart of the split subject - between body and specularity - resides the paternal function/enforcer of colonial intersubjective Law, due largely to the father's dual and contradictory role prescribed by the exigencies of colonial power. It is Figueiredo's father who, more than other characters, conveys both restraint and excess. In terms of the laws of whiteness, the father posits himself $v i s-\grave{a}$-vis Isabela as 'the negating law - a NO that forecloses a YES' (Rothwell 19). But the patriarchal foundations of Empire allow the father to seemingly transgress the Law - that negating interracial sex, for instance - the caveat being that the father's actions always reproduce colonial meaning and power. ${ }^{2}$ Interracial sex between white men and African women, as evidenced in the colonist women's words above, repeatedly produces the colonized feminine body - an edifice of imperial knowledge and historicization.

This seemingly irreconcilable duality of the father embodies, and is largely produced by, the machinations of colonial power and its narrativization. Under the guise of sexual constraint - such as the prohibition of imperially signified non-normative sexual preferences for women and men of color - the father presents excess as a modus operandi of his quotidian power. Figueiredo finally seems to make sense of this contradiction through her act of writing, coming to the conclusion that it is in this very conundrum (of enforcing the Law while breaking it) that her father 'was colonialism.' This paradox had of course been a subject of consideration for Freyre and others, who made sense of it through a narrative of interracial love stemming from Portuguese cultural ambivalence between Europe and the tropics. What Figueiredo's memoir teaches us regarding the tenets of Lusotropicalist discourse is that interracial sex did not blur or compromise colonial racial binaries and compartmentalizations, but rather reinforced them. Interracial sex and sexual violence were merely modes of reformulating racial difference - race as a floating signifier (as Stuart Hall called it) reifying otherness through different yet related discourses, such as those of sexuality, gender, and science.

Phillip Rothwell's seminal A Canon of Empty Fathers: Paternity in Portuguese Narrative (2007) explores the intersections of the paternal function and the construction of Portuguese nationhood and empire. He concludes that when 'the YES and NO of the paternal function [...] become a binary opposition, striving to obliterate each other, they empty paternity of its function' (174-75). The colonial space seemingly allows the father to circumvent such

2 See Chapter 4's discussion of jouissance versus pleasure, and superego versus Law in the psychic life of imperial masculinities. 
a binary. While placing Isabela's desire in line with that of Empire through a series of constraints, the father also does so by sanctioning particular YESes over the colonized body. Although interracial sex is out of the question for white colonist women, as we will explore further, Isabela is introduced to the pleasures of colonial power through her father's staging of physical violence on his African employees - a violence which Isabela emulates. Through this sort of balance, the paternal function aims to produce white heteronormative colonist womanhood within a reproduced order of power. Figueiredo's relationship with her father is thus 'built upon a division between the body of knowledge that utters a discourse and the mute body that nourishes it' (de Certeau, Writing 3).

\section{Portugal's Contemporary Imperial Narrative, and the Crypts of Historicization}

As mentioned above, the claims of Lusotropicalism continue to permeate mainstream reflections on the colonial past in Portugal. Imagery of affect such as that which infuses the aforementioned titles of bestselling retornado literature is merely one way in which the excesses of colonial power are re-narrativized or elided altogether in the contemporary Portuguese public sphere. The public focus on imperial endeavor and early modern navigation also produce similar erasures of colonial violence that dovetail with Lusotropicalism's claims of a non-violent colonial project. In 2009, for instance, the state-owned Rádio e Televisão Portuguesa held a television and online poll to select 'As Sete Maravilhas de Portugal no Mundo' ['The Seven Wonders of Portugal in the World'], the 27 candidates were all imperial monuments ranging from forts to basilicas and convents built across the southern hemisphere for colonial purposes.

In the realm of sport, the run-up to the 2010 FIFA World Cup in South Africa led to rehashing a somewhat lost tradition of attributing a team nickname ahead of a major tournament. The Portuguese national team manager Carlos Queiroz called the squad 'Os Navegadores' ['the Navigators']:

Pelo tributo que temos de fazer aos nossos antepassados e à maior epopeia da história dos portugueses. Dividiram o mundo com a Espanha e chegaram ao Japão. Temos ali um simbolismo, mas acho que o termo navegadores adaptava-se mais a esta circunstância de jogarmos na África do Sul, num sítio onde dobramas aquele cabo. ('Mais Futebol')

[We owe a tribute to our ancestors and the greatest epic of Portuguese history. They divided the world with Spain and reached Japan. It is a 
form of symbolism, but I think the term 'navigators' can be adapted to the circumstance of playing in South Africa, where we rounded that cape.]

Ahead of the 2014 World Cup in Brazil, sports daily Record conducted an online survey to determine the national team's moniker, and the winner was, tellingly, 'Os Conquistadores.' The selection of such a term for a sporting tournament held in a former colony only confirms the mainstream seduction of Portugal's imperial past.

We can think of imperialism, and perhaps power in general, as a series of overlapping and/or contradictory narratives that give meaning to power - and notably how it organizes bodies (in terms of sameness and difference), resources, capital, and land. The final decades of Portuguese colonial presence in Africa, as experienced by Figueiredo, constitute one of the clearest examples of this. While colonial power was practiced through a system of differences that perpetuated the disenfranchisement (or the de facto enslavement) of the colonized, the violability of black bodies, and the privileges of whiteness (on different scales according to class, gender, and sexuality), such a colonial reality was resignified on the postwar international stage as a culturally syncretistic endeavor. Shifting away from the paternalistic rhetoric of Europe's civilizing mission, Lusotropicalist thinkers, and subsequently Estado Novo spokespeople, posited Portugal's overseas mission as that of forming a new multicultural civilization based on interracial love. The two narratives came together for the sake of maintaining power - one narrative of difference on the ground and the other on the international front. Together, they served to consolidate imperial power, privilege, and history.

The contradictions of the father represent also the contradictions of colonialism in its conflicting narrativization, or rather, colonial discourse's multiple layers of signification. The colonial practice of power 'on the ground' and its system of race-based privileges implies its own narrativization in order to reproduce colonial hierarchies based on imperial forms of knowledge. The interpellating voices that surround young Isabela ultimately survey and reproduce the field of colonial meaning. At another level, one finds the grand narratives of Western History that focus on endeavor (i.e. civilizing mission and intercultural humanism). These are not only contingent upon the localized narratives of power and bodies, but resignify the product of these, shifting focus from slavery, rape, and exploitation to 'greater universal values.' The Lusotropicalist narrative, for instance, reformulated the meanings pertaining to African women articulated in the excerpts above. This speaks to the internal dialogisms of the imperial 
spectrum of power and historicity. In other words, the colonist site of articulation differs from the metropolitan place of historicization. The grand narrative seeks to consolidate the different experiences of power - from the metropolitan elite to the colonized subject - by means of presenting or omitting. After all, it is through historiography that power represents itself.

The grand narrative pertains more overtly to the historiographic project of the imperial West, while the 'ground' narrative produces the material and metaphysical conditions for such a project. This implies a dissonance in scenes of writing between the two, between colonists of working-class origins and metropolitan (historicizing) elites. The latter ultimately synthesizes the two, if not speaks for the former. Figueiredo's memoir asks us to see this opposition as that of a colonial narrative of Empire and a metropolitan narrative carrying overtones of Lusotropicalism and the saudade of Portuguese overseas endeavor.

At the moment of writing the memoir, it is the metropolitan narrative/ historiographic project that prevails, its scene of writing negotiating the terms by which both narratives intermingle and form a totalized and comfortable whole. Michel de Certeau speaks of the historiographic endeavor as a mode of hiding through meaning: "this project aims at "understanding" and, through "meaning," hiding the alterity of this foreigner' (Writing 2) - the sign for that which is other and outside the historiographic scene of writing. Imperial historicization, as power's writing of its past, must thus be a monological narrative project from which the heterologies (to borrow another of de Certeau's terms) of the imperial spectrum of power are hidden. Within this spectrum, the voice of the colonized is effaced and foreclosed from historicization, from the encounter to the everyday imposition of power in the colony. The colonist voice that carries out the imperial field of meaning in the colony must also be, to varying degrees, occulted from the former metropolis's historiographic reflections on its imperial project - hidden through the meaning produced about the past by historians, state television, bestselling fiction, and even sporting figures.

Figueiredo, however, cannot shake off the colonist voice, especially that of her father, who constantly reappears, much like a haunting. The first chapter/entry of her memoir establishes a tension between metropolitan historicization embedded in the present and her experience of colonial power in the past. This tension is inevitably guided by the ghostly presence of her father as she attempts to situate herself - and her colonial subjectivation - in the current metropolitan historiography of imperial exceptionalism. The father's violent role within power is, of course, incompatible with metropolitan historicization, and thus must be excluded from the recorded 
contents of the past. De Certeau argues, however, that 'these voices whose disappearance every historian posits, but which he replaces with his writing - "re-bite" [re-mordent] the space from which they were excluded; they continue to speak in the text/tomb that erudition erects in their place' (Heterologies 8). We can therefore approach Figueiredo's memoir as a spectral text, not only with regard to the apparitions of her father, which imbue the writer's memory, but most importantly with regard to how the memoir intervenes in the present.

\section{Spectrality and Imperial Public Sphere}

Jacques Derrida is widely credited with bringing forth the spectral turn in critical theory and cultural studies with his Specters of Marx (1993), which conceives spectrality as a fundamentally ethical project:

If I am getting ready to speak at length about ghosts, inheritance, and generations, generations of ghosts, which is to say about certain others who are not present, nor presently living, either to us, in us, or outside us, it is in the name of justice [...]. It is necessary to speak of the ghost, indeed to the ghost, and with it, from the moment that no ethics, no politics, whether revolutionary or not, seems possible and thinkable and just that does not recognize in its principle the respect for those others who are no longer or for those who are not yet there, presently living, whether they are already dead or not yet born. No justice [...] seems possible or thinkable without the principle of some responsibility, beyond all living present, within that which disjoins the living present, before the ghosts of those who are not yet born or who are already dead, be they victims of wars, political or other kinds of violence, nationalist, racist, colonialist, sexist, or other kinds of exterminations, victims of the oppressions of capitalist imperialism or any of the forms of totalitarianism. (xviii)

Derrida seems to posit the specter along the lines of disenfranchisement. We surely cannot do the same with the specter of Figueiredo's father for her, he is the embodiment of colonialism. Nonetheless, the voice of this specter poses an inconvenient truth for contemporary exceptionalist historiography. In a way, the haunting of the father, and the writer's relationship with his specter, opens a possibility for 'suffering to speak'3 by reintroducing suffering into the exceptionalist narrative that strategically

3 This is part of the famous Cornel West quote, itself delineating an ethical stance: 'You must let suffering speak, if you want to hear the truth.' 
elides the violence of the past. By omitting violence, the specters of the colonized - which are also present in the memoir - are further barred from all enunciation regarding the past.

As Carla Freccero argues with regard to the ethical potential of spectrality, 'in the concern for justice, spectrality may allow an opening up - or a remaining open - to the uncanny and the unknown but somehow strangely familiar, not to determine what is what - to know - but to be demanded of and to respond' (207). The colonial spectrality of Figueiredo's memoir thus engenders a space for postcolonial de-silencing in the metropolitan public sphere - a collective ontological space where the everyday experience of nationality is negotiated through institutions, politics, and modes of mass communication. It is thus an ideological space in which 'public opinion can be formed' (Asen 117) and is 'coextensive with public authority' (Habermas 30), a space where members are interpellated into a field of meaning that narrates the present and rearticulates the past, managing the relationship between individual and nation - in this case, imperial nation. The public sphere of meaning, moreover, inevitably affects private life and the interactions of intimacy therein.

In Jürgen Habermas's idealized version (prior to co-option by bourgeois society), the public sphere represents 'a society engaged in critical public debates' (52). Meanwhile, Hannah Arendt's take on the public realm points to deep power relations that construct a 'common world' where particular 'forces' 'lead an uncertain, shadowy kind of existence unless and until they are transformed, deprivatized and deindividualized, as it were, into a shape to fit them for public appearance' (50). Arendt goes on to mention storytelling as an example of such transformations - the translation of acts into words, by which the latter substitutes the former, thus delineating historiography's modus operandi. Arendt's quote above denotes its own notion of spectrality, as a shadow that is tenuously inserted into the realm of language yet resides behind the sign's public circulation. The same can be said regarding Portuguese imperial historiography and the aforementioned examples of colonial narratives presented in various cultural realms (literature, media, sports) that reproduce the Portuguese 'imagined community' (Anderson) or the Arendtian 'common world.'

Central to this common world of Portugueseness is the construction of time, namely the mournful chronometry of the imperial past, as what Dana Luciano has called 'sacred time,' referring to 'the altered flow of time experienced by the mourner' (7). The collective experience of mourning cannot, however, be separated from the power to produce meaning in the public sphere - and who holds such a right to signify; 'dirigentes pátrios' ['directors of nationhood'] as Eduardo Lourenço would call them 
(44). Drawing upon Freud's opposition of mourning and melancholia through Luciano's stance, we can think of mourning as a political project of signification by which the object of loss is established; as opposed to melancholia, by which grief is detached from meaning, directed toward an unsymbolized phenomena, an 'unknown loss' (Freud 245). In the political project of mourning, the power that regulates the public sphere traces the parameters of what is worthy of mourning, or 'entitled to veneration' (Luciano 7), transforming the past into a consumable version of itself, the consumption of which informs notions of Portugueseness.

One can oppose this signified object of loss to Lourenço's remarks regarding the psychological vestiges of empire in the Portuguese soul:

marcas duradouras na alma de quem 'teve' quinhentos anos de império nada, ou só a fiç̧ão encarecente que n'Os Lusíadas ecoa, não como mudadora da sua alma, mas como simples nomenclatura extasiada de terras e lugares. (44-45; emphasis original)

[long-term scars on the soul of he who 'had' five hundred years of an empire of nothing, or just the needy fiction echoed by The Lusiads, not as something that changed his soul, but as a simple ecstatic nomenclature of lands and places.]

For Lourenço, Empire was always already a loss of nothing, a void over which fictions and stories were inscribed, a phenomenon not experienced by the vast majority of the metropolitan population. To put it in Arendtian terms, the past of Portugal's imperial project was the shadowy, uncertain existence that was transformed to produce a common experience.

Drawing on Freud, Patrícia Vieira crucially associates the loss of empire in the contemporary Portuguese public sphere and cultural imaginaries with melancholia, which occurs, for Freud, at a far more insidious level - that of the unconscious. In relation to mourning, Vieira argues that 'a melancholic approach to the former overseas territories would entail a failed process of mourning the lost empire and the attempt to integrate its idealized image in contemporary life, a condition that comes through in several recent novels and films' ('Imperial Remains' 281). In both her above-cited article and her work on Portuguese colonial cinema of the Estado Novo period, 4 Vieira makes an interesting connection between melancholia and fetish with regard to Portugal's imperial project. This overseas endeavor, and the way in which it was historicized in Portuguese cultural production,

4 See Vieira's Portuguese Cinema, 1930-160: The Staging of the New State Regime. Trans. Ashley Caja. New York: Bloomsbury, 2013. 
she argues, owes much to the loss of Portuguese historical agency on the global stage and within Western modernity, beginning in the late sixteenth century. Thus late Portuguese imperialism is historicized in relation to early Portuguese expansion. Vieira ties the fetishization of empire evident in twentieth- and twenty-first-century Portuguese film and literature as a sustained stand-in for the lost object - a dominant place within the global symbolic realm of power.

Although there is a level of mourning in Figueiredo's Caderno revolving around the tumultuous paternal figure, the spectrality of colonialism (embodied by the father) destabilizes public historiography by disrupting the political project of mourning/melancholia and the sacredness of the mourned object. The revenant, Derrida's term for ghost, is 'that which comes back' (Specters 224, n.1), which 'comes from and returns to the earth, to come from it as from a buried clandestinity (humus and mold, tomb and subterranean prison)' (Specters 116). The clandestinity of the father's place in the past must thus be barred from the venerability of the lost object that structures the present - the cohesive signifying chain of Portugal's exceptionalist imperial past. Given Derrida's philosophical project of understanding the ways and ends in which meaning is produced through exclusion, presence, and absence, it is no wonder that he was interested in Abraham and Torok's notion of the crypt. Furthermore, in Derrida's foreword to their The Wolf Man's Magic Word: A Cryptonomy (1986), one can grasp the stirring of his interest in spectrality and its relationship to presence through his treatment of the crypt. What is more, his reflection on the crypt can help us better comprehend the spectral function of Figueiredo's memoir.

\section{The Framework of Cryptonomy}

As a location of meaning, the crypt is 'not a natural place [lieu], but the striking history of an artifice, an architecture, an artifact: of a place comprehended within another but rigorously separate from it, isolated from general space' (Derrida, 'Foreword' xiv; emphasis original). In other words, the crypt is not simply an artifice in itself, constructed by meaning. The term refers, also (not rather), to a layer of signification outside the crypt; the running narrative that historicizes an existing signifying chain, reformulating by way of presenting and omitting. Figueiredo places her memoir in opposition to the cryptonymic framework of imperial historicity, its 'system of partitions, with their inner and outer surfaces [...] the assembled system of various places' (Derrida, 'Foreword' xiv). Imperial historicity, as a crypt, takes on a shifting existence within what Derrida calls the 'forum' or 'public square' - 
'a place where the free circulation and exchange of objects and speeches can occur' ('Foreword' xiv). In this public sphere, 'the crypt constructs another, more inward forum like a closed rostrum or speaker's box, a safe: sealed, and thus internal to itself, a secret interior within the public square, but, by the same token, outside it' ('Foreword' xiv). In other words, by residing within the inner partition of the Portuguese exceptionalist imperial narrative, Figueiredo's father is subsequently masked within a tomb of the Portuguese public sphere. The cryptic safe of imperial historicization 'protects from the outside the very secret of its clandestine inclusion' ('Foreword' xiv). To be sure, the father is inevitably included in this historicization - as he participated in the material construction of power - but as a safeguarded secret, written over through the transformational process of historical inscription. Hence Derrida's insistence that the crypt also implies the significational means by which it is hidden.

It is through the absence of the father and his violence (in the forum) that a particular version of Portuguese imperial history is made present in the now - the forum's temporal present. Imperial presence as the object lost through decolonization is recovered through inscription in the forum - an example par excellence of the politically strategic chronometric reordering which Luciano addresses above. Such a reordering of time is predicated on the crypt's 'sepulchral function' (Derrida, 'Foreword' xxi) here Derrida begins to expound upon a nascent theorization of spectrality regarding the crypt. The cryptic underpinnings of imperial chronometric reordering situate the crypt's inhabitant as 'a living dead, a dead entity we are perfectly willing to keep alive, but as dead, one we are willing to keep, as long as we keep it, within us, intact in any way save as living' (Derrida, 'Foreword' xxi). The specter, as a clandestine entity vis-à-vis the imperial forum where the exceptional narratives of the past reside, must be continuously relegated to the inner crypt. This significational location, or non-location, is, as Derrida argues, 'the haunt of a host of ghosts, and the dramatic contradiction of a desire' ('Foreword' xxiii), in this case the paradox of inscribing an imperial history without the violent means by which domination was achieved and sustained over land, bodies, and markets. This gets to the heart of Derrida's characterization of the crypt as 'a tale of a tale, of its progress, its obstacles, its delays, its interruptions, its discoveries all along a labyrinth' ('Foreword' xxiii). The outer crypt - in its historicizing fictional function - resignifies the movements, the fictions of the inner crypt - the lies that structure colonial power (i.e. the intertwined fantasies of whiteness and colonial otherness that dictate exploitation and societal compartmentalization).

With the passing of time, the outer crypt becomes more ubiquitously 
reproduced across Portuguese post-imperial society, including among other former colonists, at whom Figueiredo launches a scathing accusation:

Mas parece que isto era só na minha família, esses cabróes, porque segundo vim a constatar, muitos anos mais tarde, os outros brancos que lá estiveram nunca praticaram o colun [...], o colonis [...], o coloniamismo, ou lá o que era. Eram todos bonzinhos com os pretos, pagavam-lhes bem, tratavam-nos melhor, e deixaram muitas saudades. (Caderno 49)

[But it looks like this was only the case with my family, those jerks, because as I came to notice, many years later, the other whites that were there never practiced colon (...), colonis (...), colonialism, or whatever it was. Everyone was so kind to blacks, they paid them well, treated them even better, and left many sweet memories.]

Such an outer crypt began taking shape before decolonization, of course, before the end of Portugal's overseas presence. Figueiredo's play with the word colonialismo reverts back to Salazar's renaming of Portugal's imperial project and narrative from a civilizing mission to an intercontinental nation. The term colony was of course replaced with overseas province. Decades later, Salazar's own paternal voice - toward the nation - continues to shape the crypt of Portuguese imperialism through the perpetual foreclosure of the terms colony, colonialism, and their derivatives. The barred terms naturally destabilize the narrativization of the past - they are to remain in the inner crypt, the domain of Figueiredo's father. They point to the unspeakable presence that was to be made absent at the level of the outer crypt. In the realm of Portuguese nationhood, or its Arendtian forum, these signifiers and their exploitative and exclusionary connotations can nonetheless intrude into the present, as they do for Figueiredo.

This embodies the haunting that speaks to a relationship between a subject and the crypt - along with its specters - as a particular signifying chain to which the subject is bonded. 'To be haunted,' Avery Gordon argues, 'is to be tied to historical and social effects' (190). More specifically, haunting is 'a process that links an institution and an individual, a social structure and a subject, and history and a biography' (19). It is through the father that Figueiredo is inextricably tied to the social effects of the inner crypt, the reality of everyday colonial life that continues to be rewritten decades after decolonization. The specter of the father binds her to the inner crypt and its ghostly signifiers that compose colonialism's field of meaning. 


\section{The Omniscience of the Paternal Specter}

Figueiredo's memoir is more than a denunciation of the quotidian atrocities of Portuguese colonialism embodied in the paternal figure. The father was, after all, an instrument for something larger - the reproduction of colonial power and its system of differences. Figueiredo exposes the inner crypt by retracing her placement into the physical and discursive space of the colony, namely its racial discourse and underpinnings. In addition to the earlier passages pertaining to a colonial space of white cisgendered female inscription, from which Figueiredo learns her body in racial and sexual terms, the memoir is rich in other examples of her gendered and racialized interpellation within Empire:

Era absolutamente necessário ensinar os pretos a trabalhar, para o seu próprio bem. Para evoluírem através do reconhecimento do valor do trabalho. Trabalhando, poderiam ganhar dinheiro, e com o dinheiro poderiam prosperar, desde que prosperassem como negros. Poderiam deixar de ter uma palhota e construir uma casa de cimento com telhado de zinco. Poderiam calçar sapatos e mandar os filhos à escola para aprender ofícios que fossem úteis aos brancos. Havia muito a fazer pelo homem negro, cuja natureza animal deveria ser anulada - para seu bem. (Caderno 51)

[It was absolutely necessary to teach blacks to work, for their own good. So that they could evolve by recognizing the value of work. By working, they could earn money, and with money they could prosper, so long as they prospered as blacks. They could cease living in a hut in order to build a house of cement and zinc. They could then wear shoes and send their children to school to learn trades that are useful to whites. There was so much to do for the black man, whose animal nature was to be eliminated - for his own good.]

While the epistemic violence of a European civilizing mission was removed from Portugal's official imperial narrative at the time of Figueiredo's childhood, it continued to inform interactions between black natives and white colonists. The paternalism of colonial discourse was, of course, most strongly conveyed to young Isabela by the paternal figure himself. As a result, as Isabela is placed into the racialized and gendered division of labor upheld by Empire's discursive fabric of alterity, so too are the colonized subjects with whom she comes into contact. The task of persistently interpellating black bodies into the colonial order, through labor and desire for colonial labor, dialectically becomes part of the colonial father's own imago. As Figueiredo 
makes abundantly clear, this division of labor, reproduced through the father's mandate, must perpetuate the racial class system. In other words, racialized labor exclusively serves white wealth accumulation (even in the case of lower middle-class families like Figueiredo's) over that of colonized subjects. This particular passage thus embodies the memoir's strongest rebuttal to mainstream Lusotropicalist views of Portugal's imperial past by placing racial discourse as a structuring tool of colonial society in its many components - from the formation of colonial identities to the meaning ascribed to sexual practices and access to capital.

Returning to Lacan, the father - or rather, the Name-of-the-Father - is the signifier through which the subject identifies with a symbolic order or field of meaning. The father's role in the symbolic is to mediate between the desire of the subject/offspring and the discursive fabric of social organization. In Lacan's words, the 'true function of the father is to fundamentally unite (and not set in opposition) a desire and the Law' (Écrits 698). For Lacan, the father is always synonymous with the symbolic order. It is the father who intervenes in the imaginary relationship between child and mother by enunciating and enforcing the symbolic order and its social relations. There is, in Lacan's theorization, a hint of spectrality concerning the father's role $v i s-\grave{a}$-vis the subject. Firstly, his presence destabilizes the pre-Oedipal imaginary, ultimately reordering the terms by which the subject relates to the outside world. More importantly for Lacan, the father as signifier and function in the realm of meaning takes precedence over the father as an actual person. Peter Guy further underscores the spectrality of Lacan's elaboration of the father: 'paternal power is linguistic rather than corporeal [...]. The name of the father is an epitaph, destined to outlive the dissolution of the flesh and Lacan insists that death inheres in language as a whole, where every vocable enfolds a void' (42). From her placement into colonial ideology to her reaction to the outer crypt of the Portuguese imperial narrative, Figueiredo's father is the constant haunting presence in her life - ever-present and interventive even in death. The father is, for her, equivalent to colonialism - its praxis of power, and of course its language as the symbolic realm where such power resides over its Real void.

The father's colonial actions - categorizing, compartmentalizing, and castigating the bodies that occupy colonial space - follow her and make themselves present in her own actions. In one vignette from the past, young Isabela accompanies her father to the city's caniços [shanties] to seek an employee who had not shown up for work that day. Inside her father's truck:

eu ia atrás, voando sobre o solo vermelho, espreitando pelos recortes no muro de caniço atrás do qual se escondia a vida dos negros, essa 
vida dos que eram da minha terra, mas que náo podiam ser como eu. Eram pretos. Era esse o crime. Ser preto. Depois o meu pai encontrava o lugar, é aqui que mora o Ernesto? Onde está o preguiçoso? A mulher apontava a palhota. $O$ meu pai largava-me a mão e entrava, enquanto eu ficava cá fora abraçada ao meu peito, no meio das galinhas, dos filhos descalços do preto, da preta, dos outros pretos todos da vizinhança que tinham visto o branco e vinham saber.

O meu pai gritava lá dentro, e aos safanóes trazia-o para fora, atordoados ambos. Segunda, vais trabalhar, ouviste? Segunda, estás nas bombas às sete. Vais trabalhar para a tua mulher e para os teus filhos, cabrão preguiçoso. Queres fazer o quê da vida? Safanão. Soco. E a mulher e os filhos e o bairro todo, e eu, estávamos ali, imóveis, paralisados de medo do branco.

E eis que o branco mete uma nota na mão da negra e diz-lhe, dá de comer aos teus filhos; depois levanta-me no ar, atrás de si, presa pelo seu pulso, enquanto grita ao negro, Segunda, nas bombas, ai de ti.

[...] E o homem branco que me leva pela mão voando, atravessa o caniço veloz, procura a Bedford estacionada lá fora, senta-se, póe o motor a trabalhar, arranca, olha para mim, então estás cansada, queres ir beber uma Coca-Cola? Queres que te deixe provar o meu penalti? Olho-o, não respondo. Aquele homem branco não é o meu pai. (Caderno 52-53)

[I would ride in the back, flying over the red soil, peeking through the cuts in the wall behind which the lives of blacks were hidden, those lives of people who were from the same country, but could not be like me. They were black. That was the crime. Being black. My father would find the place, does Ernesto live here? Where is that lazy hobo? His wife would point to the hut. My father would let go of my hand to go inside, while I remained outside hugging myself, among the chickens and the barefoot children of the black men and women of the neighborhood who had seen the white man arrive and come to see what was happening.

My father was shouting inside and, manhandling Ernesto, brought him outside. 'On Monday, you are going to work, you hear me? On Monday, you will be at the station at seven. What do you want to make of your life?' A shove. A punch to the face. And his wife and children and the entire neighborhood, and myself, were there, immobile, paralyzed by fear of the white man.

And then the white man places a bill in the hand of the black woman and tells her, feed your children; he then lifts me up in the air, behind 
him, grabbing on to his wrist as he shouts at the black man, 'Monday at the station, don't you dare not show up.'

(...) And the white man who takes me flying by the hand crosses the shantytown, finds the Bedford parked outside, sits down, starts the engine, pulls out, looks at me, 'So you're tired, do you want to drink a Coca-Cola?' I look at him without replying. That white man is not my father.]

The actions of Figueiredo's father can be found at the core of her experience of Empire's crypt. As paternalistic agent, he carries out colonialism 'on the ground,' reproducing imperial power by exercising physical, epistemic, and significational power over othered bodies while preserving imperial fantasies of whiteness. In terms of the gendering of racialized power, this particular scene embodies the inter-masculine dynamics of slavery explored in Chapter 1 in the context of Oswald de Andrade's poem 'fazenda antiga.' As much as she wishes to separate her father from colonial power and violence, she cannot. Father and colonialism are not two separate entities, they each supplement the other.

Her father's words and actions inevitably inform her own within colonial society and especially its racial structure. His ubiquitous presence, even in absence, regulates and oversees her relationship with the colonized. It is no surprise, then, that the blog entry following that of her father's assault on Ernesto begins with a confession:

Nunca tinha batido em ninguém, mas dei-lhe uma bofetada, porque ela me irritou, porque não concordou comigo, porque eu é que sabia e mandava e estava certa, porque ela tinha dito uma mentira, porque me tinha roubado uma borracha, sei lá por que lhe dei a maldita bofetada!

Mas dei-lha, [...]. Era a Marília.

Foi premeditado. Tinha pensado antes, se ela voltar a irritar-me, bato-lhe. Podia perfeita e impunemente bater-lhe. Era mulata. (Caderno 55)

[I had never hit anyone, but I slapped her in the face, because she irritated me, because she didn't agree with me, because I am the one who knew and gave orders and was right, because she had lied, because she had stolen a rubber band from me. Who knows why I hit her!

But I did (...). It was Marília.

It was premeditated. I had thought about it earlier: if she bothers me again, I will hit her. I could hit her without punishment. She was a mulatto.] 
The hypothetical reasons Figueiredo gives for her actions all reference those used by her father in his interactions with his non-white employees - control over knowledge, the colonial construction of truth, anxiety over private property, disavowal of the colonized's desire. Her violent actions, like those of her father, are of course sanctioned by the law: 'Era mulata e não podia bater-me' [She was a mulatto and therefore could not hit me'] (Caderno 55).

The haunting presence of Figueiredo's father, before and after death, underscores the spectrality of the specular image that Isabela understands to be her father - the Lacanian imago of false identitarian totality assumed by the subject in the mirror stage. In this regard, the events of the mirror stage are not limited to one particular moment. Rather, subjectivation the formation of the ego - is a constantly repeated process guided by the persistent specters of ideal ego and interpellator. For Figueiredo, the father is the intersection of both. On the one hand, in occupying the paternal function vis-à-vis Isabela's psychic existence, he formulates her desire in accordance with the Law of colonial relations. On the other, in carrying out the paternalistic project of European occupation, he must embody the ideals of Western subjective totality and the underpinnings of Western universality - heteronormative masculine whiteness.

The very next entry after recalling Figueiredo's violence against Marília highlights this additional aspect of the father's spectral psychic presence. In other words, in the span of three entries, Figueiredo traces the father's reproduction of colonial meaning and power, his placement of her desire within it, and his own identitarian performance for the Portuguese imperial project. Figueiredo recalls spending time eating piri piris, challenging herself to show no weakness against the pepper's spiciness. The ultimate goal was to 'ser forte como o meu pai. Ser forte como o meu pai desejava que fosse' ['be strong like my father. Be strong like my father wanted me to be'] (Caderno 57). These two short sentences succinctly convey the haunting centrality of the father in the psychic dwelling of colonial life. The father is thus always a multiple ghost - self and desire, ideal ego and interpellator, in one specter. As a result, young Isabela is stuck in the ambiguity of her father's multifarious place and role within Empire; between following his own imperial performativity or the gendered direction of her imago.

The father's repeated apparition - constitutive of subjectivation - always enunciates a colonial narrative, a field of meaning and set of knowledge that resides in the inner crypt of the imperial past. Interpellation into the symbolic realm of meaning is much more than a 'hailing' (Althusser 171). It is a moment of narration in which the interpellating agent re-narrates the field of power, now with the interpellated subject in it. But his re-narration is not confined to one particular moment. It is a haunting reoccurrence 
driven by Figueiredo's father's actions: the beating of Ernesto, the daily distribution of work among his employees, his political conversations with fellow colonists, etc.

\section{The Father and Colonial White Womanhood}

Although the aforementioned space of colonist women gathering is one in which colonial categorization of bodies and genitalia is carried out, and the white female body is surveyed, it is nonetheless the father who administers the disciplinary consequences of the categorization. Isabela learns of her racialized genitalia through the female public space and debate, but it is her father who physically imposes the categories by disciplining the body accordingly. Reflecting on her romantic feelings for the son of a black neighbor, Figueiredo recalls her fears:

Se eu estivesse grávida do preto, o meu pai podia matar-me, se quisesse. Podia espancar-me até ao aviltamento, até não ter conserto. Podia expulsar-me de casa e eu não seria jamais uma mulher aceite por ninguém. Havia de ser a mulher dos pretos. E eu tinha medo do meu pai. Desse poder do meu pai. (Caderno 43-44)

[If I fell pregnant by the black boy, my father could kill me, if he wanted. He could have beaten me to a pulp. He could have expelled me from my home and I would no longer have been accepted by anyone. I would have been a black man's woman. And I feared my father. That power my father possessed.]

The interpellational agency of white colonial paternalism implies such executive power. Through it, the father not only places the subject - Isabela - into meaning, he also retains the power to decide where she will reside within colonial meaning. Paternal power over the home is, of course, tied to the paternalistic power over colonial space, conferring to the father the ability to marginalize Isabela's body from both intertwined spheres of life the private and the public. He enforces the order of the home and the racial/ sexual taxonomies of the colony.

Contrary to the Lusotropical narrative of interracial love, whether public or private, the union carried damning consequences for the white female subject that it did not for the white male - as is underscored by Isabela's father's sexual liaisons with colonized women. Ensnared in white colonialist patriarchy and its signifying privilege, the interracial liaison ascribes to white women's bodies symbolic devaluation due to sex with abjectified bodies. For Isabel, more so than for her father, interracial sex is 
coded as deviant because it goes against the significationally reproductive prerogatives of Empire's white patriarchal heteronormative core. As such, Isabela would become a signifier of failed whiteness, especially in contrast with the colonialist role ascribed to white women - ensuring the purity of whiteness, especially through the construct of the nuclear family.

Ana Paula Ferreira illustrates and underscores how, in the context of Estado Novo Portugal and its late colonialist discourses, the regime's "institutionalization of Portugueseness" could not have been achieved without the rhetorical involvement of womanhood and femininity as ideological signs, and of women and those deemed "different" as socio-political subjects' ('Homebound' 134). Ferreira goes on to point out that 'the Estado Novo relied on and in turn generated a consensual fictional poetics of womanhood and femininity encompassing heterogeneous spaces and peoples characterized as "naturally" different' ('Homebound' 134). The Estado Novo's ensnarement of women into nationalist and imperial ideology subsequently carried a colonialist functionality, while maintaining a well-defined white patriarchal order based on a family structure by 'contain[ing] women within the family unit - while at the same time colonizing all subjects of difference under the aegis of the greater national family' (Ferreira, 'Homebound' 134).

Margarida Calafate Ribeiro's research on the role of women as agents of Estado Novo nationalist and colonialist discourses provides in-depth explorations of how this relationship was officially conveyed through the regime's different propaganda machines. One of these was the Movimento Nacional Feminino [National Women's Movement], which began as a grassroots women's group in support of Portugal's colonial wars in Angola, Guinea-Bissau, and Mozambique. Ribeiro examines the ideological functions of the movement through (and beyond) its publications, noting that:

eram feitos apelos às máes portuguesas para que sacrificassem os seus filhos 'pela Nação,' nos jornais da época, nacionais e principalmente regionais, eram aplaudidas as mulheres que tinham muitos filhos e que os 'davam' para a defesa do ultramar português. ('Mulheres portuguesas' 288)

[pleas were made to Portuguese mothers to sacrifice their sons 'for the Nation' in the newspapers of the period, national ones and especially regional ones. Women with many children were celebrated for 'giving' them in defense of the Portuguese overseas empire.]

The movement's publications thus enunciate a Portuguese nationalist maternal subject whose desire is circuited to that of the Estado Novo, while reinforcing patriarchally ascribed gender roles, the concomitantly gendered 
division of labor, and the underlying rigid gender binary, now in the name of Empire.

Within the purview of ascribed gender duties vis-à-vis nation and empire, the role of Portuguese women also implied their role in relation to family and colonization. On this topic, Ribeiro cites Maria Archer who, despite seeking exile in Brazil due to her opposition to the Estado Novo (namely its discourses on women), nonetheless embraced Portugal's colonial mission, at the core of which she posited women: 'Archer, referindo-se à falha da colonização portuguesa em África, "uma civilização só se fixa e define através da mulher"' ['Archer, referring to the failure of Portuguese colonization in Africa, (wrote) "a civilization can only establish and define itself through the woman"'] ('Mulheres portuguesas' 289). Archer's understanding of the colonial role of women, shared by the Estado Novo as reflected in its propagandistic mission to bring more families to the colonies, thus places women at the core of both Portugal's civilizing mission and its cementing of whiteness and white presence overseas.

In her genealogy of racial segregation in colonial life, Ann Laura Stoler explores the relationship between larger influxes of European women to the colonies and the greater stratification of colonial society, along with the conflicting notions and stereotypes regarding female colonists:

The arrival of large numbers of European women coincided with new bourgeois trappings and notions of privacy in colonial communities. And these, in turn, were accompanied by new distinctions based on race. European women supposedly required more metropolitan amenities than did men and more spacious surroundings for them. [...] Their psychological and physical constitutions were considered more fragile, demanding more servants for the chores they should be spared. In short, white women needed to be maintained at elevated standards of living, in insulated social spaces cushioned with the cultural artifacts of 'being European.' [...] Segregationist standards were what women 'deserved' and, more importantly, what white male prestige required they maintain. (55)

Regardless of who set these standards, it is apparent that colonial segregation followed a bourgeois logic; often this was a lifestyle that implied a sort of social mobility for Portuguese colonists, the majority of whom hailed from a rural working-class background (Castelo 2007). Colonial space was thus one where European bourgeois fantasies could be acted out. It is within the sphere of bourgeois social values that the white female body is enveloped, signified, and surveyed. The racial boundary cannot, of course, be separated from that of class; the logic of colonial power deeply intertwines them. 
Portuguese colonization of Africa in the twentieth century was not solely predicated on the migration of Portuguese women to the colonies, but on the import of the nuclear family structure. The construction and performance of class in the final decades of Portugal's colonial presence in Africa is thus centered on the family and white heterosexual marriage as bourgeois institutions of Western modernity. In the colonial setting, the power dynamics internal to these gained increased racial components while further reinforcing colonial compartmentalization. A white wife became a signifier of status within the colonial setting, enunciating a public family narrative of white bourgeois - and thus normative - sexual practices. As a colonial marker of whiteness under the rules and regulations of a white patriarchal gaze, white colonist womanhood was to be isolated from sexual pleasure - especially interracial sex - at all costs. The white colonial female body, as Figueiredo's memoirs render it, was thus produced to be an instrument and index of colonial power. Sexual pleasure was the sole reserve of white imperial masculinity. Female sexual enjoyment, on the other hand, was potentially fatal to the reproduction of imperial power, from the bourgeois colonial microcosm of family life to the ideological superstructure of Empire. To quote from Foucault's genealogy of sexuality and bourgeois values, 'the familial and civic status of a married woman made her subject to the rules of conduct that was characterized by a strictly conjugal practice' (145-46).

Colonial whiteness, in its pure bourgeois form, thus depended on the strict control over white female sexuality and the systemic curtailing of non-reproductive pleasure. This stood, of course, in stark opposition to the freedoms afforded to white masculinity: 'no sexual relation was forbidden to him [...] he could have an intimate affair, he could frequent prostitutes, he could be the lover of a boy - to say nothing of the men or women slaves he had in his household at his disposal' (Foucault 146-47). Aside from enjoying this freedom, Figueiredo's father is responsible for maintaining whiteness through the bourgeois distribution of pleasure in the colonial space. After all, 'subversions of the bourgeois order were those that threatened that repertoire of sensibilities glossed as "personal character" and that marked who was eligible to be classed as white' (Stoler 157).

Figueiredo's father takes up the mandate of producing colonist womanhood throughout her youth. She notably recalls a particular episode related to her preadolescent sexual curiosity, prefacing the memoir entry: 'Foder. Essa descoberta tornou-se algo que me envergonhava e desejava. Tinha os tais sete ou oito anos' ['Fucking. That discovery became something that embarrassed me, but that I desired. I was about seven or eight years old'] (Caderno 29). While playing in a nearby abandoned construction site (a 
new house for an arriving colonist family) with a white neighbor close to her in age, Luisinho, they agree to 'jogar a foder' ['play-fucking'] (Caderno 29):

Despimo-nos completamente, eu deitei-me sobre a terra, exactamente como nos ensinavam que se devia dormir, pernas e braços direitos, o Luisinho deitou-se nuzinho sobre mim, exactamente como nos ensinavam na escola que se devia dormir, e ali ficámos alguns minutos, nessa posição de difícil equilíbrio, conversando e 'fodendo.' Eu estava por baixo e podia ver a abertura já existente onde se situariam as janelas. E, num ápice de segundo, apercebo-me da figura do meu pai, oh, meu Deus, o meu pai, estou a vê-lo ainda hoje, debruçado nesse vago, com os antebraços pousados no tijolo, olhando para baixo, observando a cena, apercebendo-se da situação e desaparecendo rapidamente. Percebi tudo. Nessa fracção de segundo levantei-me, derrubando o Luisinho, e agarrando a minha roupa. No momento em que o meu pai deu a volta ao exterior da casa, entrou pela porta e me arrebatou pelo braço, estava o Luisinho ainda em pelota e eu já meia vestida. Segundos antes da pancada, tinha já a certeza absoluta que foder era proibidíssimo. (Caderno 30)

[We got completely naked, I lay down on the ground, exactly how they taught us we should sleep, legs and arms straight, and Luisinho lay down on top of me in the exact same way, and there we stayed in that acrobatic position, talking and 'fucking.' I was on the bottom and could see the hole where the windows would go. And, in a split second, I noticed my father, oh my God, my father, I can still see it today, leaning into that hole, forearms resting on the brick, looking down, observing the scene, realizing what was happening and quickly disappearing. I understood everything. In that fraction of a second, I got up, throwing off Luisinho, and grabbing my clothes. When my father rounded the house and came inside, and grabbed me by the arm, Luisinho was still naked and I was already half dressed. Seconds before the beating, I already knew for sure that fucking was strictly prohibited.]

This particular memory captures the father's spectral being as a gaze. Even before the father deals a punitive blow, Isabela fully comprehends the sexual prohibition explicit in the very presence and surveillance of her father. This comprehension, one that genders her within the imperial field of meaning, is inevitably traumatic to the point that it continues to haunt her 'ainda hoje' ['even today']. This moment from her childhood - for her, a primordial scene of her father's intervention in her sexual desire - ultimately provides an image to the father's interpellational gaze. This embodiment of a gaze 
into a traumatic image-apparition is inevitably a product of the racialized and gendered configuration of colonial society. The colonial patriarchal system, entrusting the paternal figure with the power of surveillance and the enforcement of the Law, provides him almost boundless spatial access from the colonial home and its surroundings occupied by the family to the city's outskirts occupied by the colonized subaltern.

It is this gaze that stalks Isabela's early sexual relations and manifestations of desire, a Lacanian partial object that enunciates the patriarchal imperial desire to reproduce white heteronormative femininity. Elaborating on Freud, Lacan explains that partial objects such as gaze and voice 'represent only partially the function that produces them' (Ecrits: Selection 315). Through the father, the partial object, Empire's gaze takes the form of a spectral body - a haunting and persistent image giving a sensory feel to spectral experience.

Through the power conferred on him by the imperial field of meaning and power, the father also becomes an object of desire - not only as ideal ego, the specular image of colonist identity, but as an incestuous object of desire for Isabel. This, however, has more to do with the father's role as ego-ideal than as specular image. As the interpellator and surveyor of her identity and performativity as white colonist woman, her existence as gendered subject within the symbolic realm is dependent on the father's appraisal and acceptance - on his love for her. Figueiredo notably reminisces over the joy she felt in his presence during their frequent leisure outings:

Eu gostava da sua presença, de passear com ele a pé, por onde quer que fosse, de mão dada [...]. Era muito grande e muito poderoso como um rei-gigante, e a sua presença protegia-me de todos os medos irracionais. Acho que nunca fui tão feliz como nesses momentos em que me pegava pela máo e caminhava comigo pelas ruas de Lourenço Marques, até ao Scala, até depois do Scala, vendo montras, pessoas, sentindo cheiros vindos de todo o lado, ao entardecer, enquanto as luzes das avenidas e dos néons se iam acendendo [...]. Todos os meus sentidos despertavam nesses fins-de-tarde.

Sentia-me uma pessoa. Sentia-me uma mulher. A sua alma-gémea.

Năo houve nenhum homem capaz de me resgatar como ele, de me quebrar, de me dar vida só por existir. Só por estar ali, sorrir-me, dar-me valor. Dar-me a mão. Pegar em mim. Escutar-me. (Caderno 81)

[I had enjoyed his presence, strolling with him, to wherever, holding his hand (...). He was very tall and very powerful, like a giant king, his presence protected me from all irrational fears. I don't think I have ever been as happy as I was in those moments when he would take 
me by the hand and we would walk through the streets of Lourenço Marques, to Scala, and even past Scala, window shopping, looking at people, smelling the scents coming from everywhere, until late, when the lights of the avenues and signs would light up (...). All my senses would awaken in those late afternoons.

I felt like a person. I felt like a woman. His soulmate.

No man was able to rescue me like him, able to break me, able to give me life just by existing. Just by being there, smiling at me, valuing me. Holding my hand. Picking me up. Listening to me.]

The love she feels emanating from her father in these moments - and her corresponding filial pleasure - can be translated as the reconsolidation of her nascent imperial womanhood. Her subjective totality becomes contingent upon the reassuring presence of the father - he who oversees her desire. In desiring to be whole within the colonial field of meaning, she is taught to desire her father's presence. As the paternal signifier, he has posited himself throughout her life as the only person capable of validating the desire that he, himself, engendered for her - that she be a white woman in the imperial field of meaning.

Figueiredo seems to suggest that her father was cognizant of his grip over her when later in the same entry she recalls his wish that she never become dependent on any man: 'Tens de ter uma profissão que te permita viver a tua vida, com os teus filhos, ou năo, sem depender de nenhum homem! Sem estares às custas de ninguém. Tens de ser dona da tua vida. Tens de ser livre' ['you must have a profession that allows you to live your life, with your children, or without, without depending on a man! Without depending on anyone. You must own your life. You must be free'] (Caderno 82). On the surface, her father's injunction seems to be overtly emancipatory. We cannot, however, separate the words from their enunciator. 'Being free' does not necessarily suggest being free from him. In other words, his demand does not displace his desire; it enunciates his desire. Naturally, under the semblance of freedom, Isabela has no choice but to oblige:

'Para isso tens de estudar, tens de ir para a universidade!'

'Sim. Eu vou.' (Caderno 82)

['For that you must study, you must go to university!' 'Yes. I will go.']

The ocular emphasis Figueiredo gives to the father in the last three passages tacitly betrays the larger multi- or even extra-sensory impact of the specter. The very terms often used to discuss ghosts and hauntings - such 
as 'specter' and 'apparition' - seem to be etymologically centered on the visual field. Derrida, however, rejects such an incomplete take on spectrality through what he calls the visor effect:

this spectral someone other looks at us, we feel ourselves being looked at by it, outside of any synchrony, even before and beyond any look on our part [...]. To feel ourselves seen by a look which it will always be impossible to cross, that is the visor effect on the basis of which we inherit from the law. Since we do not see the one who sees us, and who makes the law, who delivers the injunction. (Specters 6-7; emphasis original)

Although the father's specter is momentarily captured in the memory of a seen image, the specter's implied gaze constantly eludes any permanent placement in the visual field, or even any tangible identification of it by the senses. In other words, the surveying gaze of power - that of the father - is only, at the very most, a fleetingly knowable presence. The father's interpellation resists temporal and spatial fixity. It is a continuous act of seeing that the subject cannot visually grasp. The field of meaning, and the movements of individual desire therein, are thus persistently formed and structured by an unseen agency.

In her nuanced exploration of seeing and its limits in the political spectrum, Patrícia Vieira offers a further interpretation of spectrality and its relation to the visual field:

Derrida reverses the Husserlian model of intentionality, where a subject directs her or his mental regard to the intended object. Here, the traditional object (the ghostly Thing) becomes the subject of vision and contemplates my blindness to the virtual, an inversion that represents a re-description of Levinasian ethics from the perspective of the other. The I who comes into the other's field of vision becomes aware of its relative position vis-à-vis the ghost; the subject is, thus, decentered, since it is no longer the origin of perception and of the phenomenological world. Further, the other is now virtual, and I am no longer able to identify it concretely. (36)

What gives the father the semblance of a body is his simultaneous existence as ideal ego and ego-ideal as well as his temporal physical presence. His injunctions, however, once voiced, do not necessitate a tangible body, as Isabela becomes the object of colonialism's spectral contemplation. Although she may eventually refuse the injunction, the specter is never fully elided from her intersubjective life. 


\section{Displacing the Father}

The father oversees Isabela's placement into imperial womanhood, and her sexuality as one of the performative components of it, within Empire's synchronization of normative gender identity and sexuality. It is through her transgressions vis-à-vis the demands of colonial gender politics, however, that she is introduced to sexual pleasure. Aside from her preadolescent experience with Luisinho, Figueiredo recalls her sleepovers at the house of a fellow colonist family and her homoerotic friendship with their daughter Domingas:

A Domingas era mais velha que eu. Tomávamos banho de imersão juntas. Eu achava-a grande, e bonita, porque já tinha mamas e pêlos púbicos, mas na verdade ela era apenas grande.

A Domingas foi quem me masturbou pela primeira vez. Logo pela manhã, com a banheira cheia de água morna, estendeu a sua perna entre as minhas, e procurou, com o pé, a entrada da minha vulva, que esfregou devagar, fitando-me trocista e rindo-se. Sabia-a toda. E eu fitei-a, e ri-me, e deixei-me ficar a olhar para ela, rindo e gozando, igualmente.

Quis tomar banho com a Domingas a vida inteira, mas depois veio - 7 de Setembro, os revoltados partiram a banheira, e tivemos de negar-nos esses prazeres tão higiénicos e marginais. (Caderno 94)

[Domingas was older than me. We would take baths together. I thought she was big, and beautiful, because she already had breasts and pubic hair, but really she was just big.

Domingas was the first person to masturbate me. Early in the morning, with the tub full of warm water, she stretched out her leg between mine, and searched with her foot for my vulva, which she rubbed slowly, looking at me and laughing connivingly. She was wise. I looked back at her, and I laughed, and I just let myself look at her, laughing and enjoying, equally and simultaneously.

I wanted to bathe with Domingas for the rest of my life, but then September 7 happened, the rebels broke the bathtub, and we had to deprive ourselves of those hygienic and marginal pleasures.]

Isabela's relationship with Domingas, breaking 'the regulatory apparatus of heterosexuality' (Butler, Bodies that Matter 12), introduces her not only to the pubescent female body, but to the sexual pleasure of her own. Although Figueiredo does not frame this experience as a direct transgression of 
the father's impositions of heteronormativity and sexual propriety, it nonetheless reveals the limits of his mandate. Against the colonial imperative of producing white femininity divorced from sexual pleasure - vis-à-vis the colonial fantasy of the lascivious woman of color - Isabela learns to recircuit her sexuality away from the desire of the father, shifting the colonist female body from Empire's instrument of reproduction to the instrument of her own pleasure. In this regard, this shift momentarily displaces the father's desire - as well as that of Empire - over her own body.

It is interesting, then, that this period of Isabela's preadolescence coincides with the final days of Portuguese colonial presence in Mozambique. Figueiredo interlaces this intimate memory with allusions to the historic date of the Lusaka Accord - September 7, 1974 - which formally transferred sovereignty of Mozambique from Portugal to FRELIMO (Front for the Liberation of Mozambique). The agreement triggered waves of violence throughout the colony as well as the mass exodus of colonists, some of whom returned to Portugal while others sought to live under white rule in neighboring apartheid South Africa and Rhodesia. Figueiredo recalls the event being understood by colonists as betrayal by the new socialist Portuguese government: 'o Almeida Santos e o Mário Soares são uns cães que nos estão a vender por meio tostăo' ['Almeida Santos and Mário Soares are nothing but dogs selling us out for a penny'] (Caderno 91). Meanwhile, she remembers, with a tone of ironic critical distance, the anti-colonial reappropriation of land and homes by the former colonized: 'os negros do Domingos estavam fartos de carregar sacos de farinha e milho e farelo que nunca eram para eles' ['Domingos's black workers were tired of carrying sacks of flour and corn that were never for them'] (Caderno 94). Amidst these larger political shifts, the centrality of her father's desire over Isabela's subjective existence is dislocated as his excessive power within colonial reality draws to an end. This last passage also points to how the struggle for independence against Portugal has been historicized in relation to Lusotropical narratives. By erasing the institutional, economic, and physical forms of violence against colonized peoples, independence movements encoded in the outer crypt of metropolitan public memory are stripped of their historical urgency and humanitarian ethics.

\section{The Specter's Persistence}

Figueiredo's relationship with the specter of the father and the crypt of Empire also reveals her entrapment within the contradictions of colonial discourse, especially regarding gender performance and sexuality. These are particularly tied to the omniscience of the father as both ideal ego and 
ego-ideal. She reads him, at different times, at both levels of identification: imaginary and symbolic. The former pertains to identification with the ideal ego, the specular image of desired identitarian totality while the latter relates to the ego-ideal, thus implying identification 'with the very place from where we are being observed' (Žižek, Sublime 116). In other words, she is stranded between following the father's masculine specular presence - evidenced in her desire to be 'forte como o meu pai' ['strong like my father'] - and following what her father wants her to be: a woman in the colony. The excessive power of the father ultimately leads to his excessive, simultaneously seeable and intangible presence, which produces confusion and anxiety in the subject he repeatedly seeks to interpellate. At the end of colonial reality, the imperial interpellation of Isabela slips out of the father's hands as she is sent to Portugal to become one more returnee and her father is imprisoned by FRELIMO forces for three years before his return to the metropolis.

Like colonial discourse, though, her father's gaze is never completely eradicated. Its spectral omniscience continues after the Portuguese colonial project, following her intersubjective life even after his death. Inevitably, the father's specter affects how she relates to the past, although she 'não conseguia ver o mundo pelos seus olhos' ['was unable to see the world through his eyes'] ('Isto é a sério' 23). Her interview, from which the last quote is taken, reveals that she felt she was betraying her father by not sharing his views: 'Uso o vocábulo traição muitas vezes ao longo do livro, porque sempre me senti sua traidora' ['I use the term betrayal many times throughout the book because I always felt I was his traitor'] ('Isto é a sério' 23). This would suggest that imperial interpellation - undertaken by her father - eventually broke down. At different points of her childhood and adolescence, Isabela refuses to read the imperial field of meaning as her father had presented it to her. The father's desire to situate his offspring within a particular symbolic realm hinges on the offspring's interpretation of it - one that must be in sync with that of the father. This then contributes to her painful inability to rid herself of the father's ghost, which always carries a supplement of the past - in this case, the symbolic realm of late Portuguese colonial settlement which she refused, in refusing the father.

In the same interview, Figueiredo suggests that one of her main objectives in writing the memoir was to confess her father's sins: 'ele não se confessou antes de morrer, e eu quero realizar essa confissão em seu nome' ['he never confessed before dying; I wish to do that for him'] ('Isto é a sério' 24). This seems to be the only way to exorcise his ghost - essentially rewriting the father by placing the inner crypt of Empire (of which he was keeper) into the outer crypt of the contemporary public sphere. If it is through the father that 
she relates to the Portuguese imperial crypt - rather than through Camóes, Lusotropical tropes, and odes to the Discoveries - then the post-imperial nation must now also deal with the father's specter as he 're-bites' the outer crypt. In keeping with Derrida's ethical formulation of spectrality, Figueiredo's own decolonial ethical project vis-à-vis the colonial past consists of staging the father's specter in the public space of metropolitan readership. By means of the memoir, Figueiredo is, in the words of Avery Gordon, 'writing with the ghosts' (7). Although the specter cannot be eliminated, it can be shared.

\section{Conclusion}

Figueiredo's memoir inserts the father - his actions and colonial mandates - into a present in which 'the postmodern, late-capitalist, postcolonial world represses and projects its ghosts in similar intensities' (Gordon 12). The present is thus a ground of contestation regarding the past, a power struggle for historicization. Resignifying the past becomes a political project along the entire spectrum of power (from local to global), serving the interests of the present whether they are emancipatory or conservative. Figueiredo's sharing of the specter acts against forgetting, which 'is not something passive, a loss, but an action directed against the past' (de Certeau, Heterologies 3). Following de Certeau's argument, the specter of the father is 'the mnemic trace, the return of what was forgotten, in other words, an action by a past that is now forced to disguise itself' (Heterologies 3-4). As we have seen, the father's specter represents a series of actions, utterances, and apparatuses that have been tentatively erased from public memory by an ongoing exceptionalist interpretation of history. It is through this series, though, that the material conditions are fostered for such a narrative and its enunciating power. In this regard, Figueiredo's memoir seeks not only to recover what is strategically forgotten by imperial power in order to destabilize imperial historicity, but also to offer a glimpse into how imperial power and historicization is (re)produced. 


\section{Spectrality as Decolonial Narrative Device for Colonial Experience in António Lobo Antunes's O Esplendor de Portugal}

\footnotetext{
$\mathrm{T}$ he previous chapter sought to unpack the ways in which Isabela I Figueiredo's memoir, Caderno de Memórias Coloniais, engages with colonial discourse in pre-independence Mozambique and how the colonial past is historicized in the contemporary Portuguese public sphere. An integral part of her critical engagement, I argued, concerns her deployment of spectrality in order to understand the underpinnings of colonial power and to destabilize dominant historical narratives, such as that of Portuguese colonial exceptionalism. Few Portuguese writers, though, have explored the depths of Portugal's colonial past in a more spectral fashion than António Lobo Antunes. His vast body of fiction dedicated to the topic and to his own experience as a medical doctor of the Portuguese armed forces in Angola during the war for independence, presents a plethora of voices that speak from a past that is often repressed at both individual and collective levels.

The earliest of his novels to receive critical acclaim, Os Cus de Judas [South of Nowhere] (1979), his second, has been regarded as a semiautobiographical account of Antunes's life up to that point, four years after decolonization. The narrator, in a stream of consciousness conversation with the reader, reflects on his childhood, sexual experiences in both Portugal and Angola, and his own imperial interpellation which leads him to witness the atrocities of Empire. His memory is articulated by the images and voices of the past, from the mutilated body of a screaming conscript to the musings of a military dentist. Drawing on Derrida, Patrícia Vieira points out the evocation of specters in Os Cus de Judas as akin to 'an archive, with which they also share the injunction to remember: a law, a story, a debt' ('Specters' 342). In this sense, the narrator's specters, each speaking their own archive and composing the archive of the narrator, become part of larger national and postcolonial archives under revision.
} 
Antunes's 1988 novel, As Naus [The Return of the Caravels] shifts from his personal trajectory to that of the Portuguese imperial narrative. In one of Antunes's few literary experiments with the fantastic, the novel follows the postcolonial trek back to the metropolis of Portugal's most famed early modern explorers. These include Vasco da Gama, Pedro Álvares Cabral, Bartolomeu Dias, and Diogo Cão. As historical figures, these men have become signifiers of Portuguese imperial lore. In the aftermath of decolonization, the protagonists attempt to find their way back to Portugal and, more importantly, struggle to integrate themselves in post-revolution Portuguese society and its collective renegotiation of nationhood. Through putrid and morbid imagery, like that found throughout Os Cus de Judas, Antunes arguably establishes parallels between the decadent characters and the societal marginalization of colonial returnees.

In being dislocated from the tomb of History, the protagonists of the past - signifiers, links of the signifying chain of Portugal's imperial narrative speak once more at the moment of postcolonial renegotiation. As Naus is, in many ways, what Margarida Calafate Ribeiro has coined 'narrativas de regresso' ['narratives of return'] that incite one to 'pensar Portugal de uma margem' ['think of Portugal from the margins'] ('Percursos Africanos' 132). The abject state in which the protagonists are presented serves, of course, as a stark contrast to their sacred place in mainstream representations of the past. Through the spectrality of the fallen protagonists, augmented by their putrid existence, the nation in its post-revolutionary present is rethought, starting with its early modern past.

Antunes takes the use of spectrality in reflecting on the Portuguese imperial project and its narrativization to another level nearly a decade later in his 1997 novel O Esplendor de Portugal [The Splendor of Portugal]. Paulo de Medeiros ties the novel to Antunes's larger auvre on colonialism, which 'giv[es] voices to thousands of corpses' (43). Medeiros thus underscores the spectral nature of Antunes's treatment of (post)colonial experiences, prefacing his analysis: 'Postcolonial texts are also at once problematizations of identity and invocations of a ghost, be it the ghost of history or more individual, particular ghosts, whose name nonetheless stands, or can stand, always for another' (39). Not only does Antunes use spectrality to problematize identity in postcolonial time and space, he ultimately turns spectrality into a narratological device, an aesthetic mode of narrating colonial experience.

At the heart of the novel is a family's tri-generational experience in Angola as colonial settlers. Each of the novel's three parts centers on a different, now adult child of Isilda, a Portuguese colonist born and raised in Malanje, Angola, who resides there until her death. The parts are themselves divided 
into ten chapters beginning with the date in which they are articulated, with five narrated by Isilda and the other five by one of her children, in alternating fashion. Those narrated by her children - Carlos, Rui, and Clarisse - are dated December 24, 1995, whereas Isilda's 15 chapters span two decades following Angolan Independence. As Maria Alzira Seixo explains, the past 'vem progressivamente chegando ao presente, a partir de 1978 até 1995' ['gradually approaches the present, from 1978 to 1995'] (322). We soon come to learn that Isilda's chapters are in fact letters she wrote to Carlos, with perhaps the exception of her last chapter, also the last of the book, which is dated December 24, 1995.

Carlos waits impatiently for his siblings to arrive for Christmas Eve dinner, an invitation he extended to them 15 years after he expelled them from his home. As he repeatedly counts down the seconds to an arrival that never happens, Isilda's letters sit unread in a drawer. They are, for Carlos, like Edgar Allen Poe's telltale heart - a piece of the past that is always present, a crypt that is a piece of narrativization. It tells a story that Carlos does not want to read, one that he not only knows, but has lived. For all intents and purposes, the mother, Isilda, is dead to her children. She is a relic of a colonial yesteryear that can have no place in the present, neither for her children nor for the postcolonial moment in which Carlos, Rui, and Clarisse speak. As we learn from the respective narrations of the children, any psychic bracketing of the colonial past from the present is impossible. Unlike Poe's telltale heart that disrupts the peace of a symbolic order sanctioned by that which is not told, the letters do not disrupt any sort of peace nor do they compromise the place of her children in the symbolic order of the present. Since decolonization, the three siblings have all resided in the metropolis as broken, marginal, and decrepit beings bearing the indelible scars of colonial life and its realm of meaning. The symbolic order in which they reside, in other words, is already disrupted and chaotic, which is characteristic of Antunes's plots.

An epileptic, Rui never escaped the stigma tied to mental illness within the discourses of colonialism, predicated on a subject possessing mastery over body, space, and the other. As such, he himself was othered, isolated from much of family life, subjected to numerous and frequent doctor visits, taking an inordinate amount of medication, and suffering seizures in public. Clarisse, meanwhile, like Isabela Figueiredo in the previous chapter, struggles to follow her interpellation as a white colonist woman and imperial power's demands of her. The first part of the book is narrated by Carlos, interrupted by Isilda's letters. Carlos is not Isilda's biological son. $\mathrm{He}$ is the product of her husband Amadeu's affair with a black woman he met while working as an agronomist. In an attempt to maintain the family's public image of whiteness, Isilda purchases Carlos from his mother. As 
we shall explore, these events and traumas, among many others, form the spectral backdrop for the novel's characters.

\section{The Novel's Spectral Composition}

If the division of the text seems structurally ordered, the content of each chapter is the complete opposite. Each is composed as a soliloquy that is constantly interrupted by the discourses of voices past. Scholarship on $O$ Esplendor de Portugal has opened various debates regarding possible categorizations for the novel's narrative structure. Isabel Ferreira Gould calls our attention to 'traços técnicos/estilísticos específicos que incluem a multiplicidade de vozes narrativas e a convergência de pontos de vista; a alternância aparentemente caótica de espaços e tempos narrativos; a intertextualidade' ['specific technical/stylistic traces that include a multiplicity of narrative voices and the convergence of various points of view; the apparently chaotic alternation between narrative times and spaces; intertextuality'] (154) in the novel, and Antunes's work in general. Gould reads $\mathrm{O}$ Esplendor de Portugal, specifically, as a series of diary entries, classifying it as 'ficção de diário' ['diary fiction'] (157). Paula Gândara, on the other hand, places the novel's narrative style into the category of interior monologue (179). I argue, though, that the novel is much harder to pin down. Its deep complexities elude divisions between writing (i.e. the diary) and thought (interior monologue), or logocentrism versus speech. While Isilda's letters are examples of writing, it is much more difficult to ascertain whether Carlos, Rui, and Clarisse are writing, internally reflecting, or verbalizing their thoughts to a silent listener.

Regardless of the mode of articulation, all the narrators in the novel produce meaning, but this is never an autonomous endeavor. Rather, enunciation for the narrators is constantly trapped within the traumas of colonial interpellation. In attempting to convey the fragmented nature of postcolonial enunciation, Antunes consistently forsakes common writing practices such as punctuation and linear horizontal writing. We can take an excerpt from the first chapter, narrated by Carlos, as an example to dissect:

- Não esperes visitas logo à noite Carlos

a Lena que previa um Natal sozinha comigo

(contar até cem outra vez, contar de cem a zero, contar até trezentos) idêntico aos últimos quinze Natais desde que como ela teima

os expulsei da Ajuda, a levantar-se surpreendida com a blusa pelo menos melhor que os trapos do Sambila 
- Não é mussequeira palavra de honra que não é mussequeira os pais dela têm o apartamento em obras juro-te que é exactamente como nós que costuma usar, adereços e penduricalhos de estanho. (Esplendor 24; emphasis original)

['Don't expect visitors later tonight Carlos'

Lena who predicted a Christmas alone with me

(count again to a hundred, count from a hundred to zero, count to three hundred)

identical to the last fifteen Christmases since as she insists

I kicked them out of Ajuda, getting up surprised with her blouse at least better than the rags from Sambila

'She is not a slum girl. I swear she is not a slum girl, her parents are having their apartment renovated. I swear she is exactly like us'

that she usually wears, accessories, tin necklaces.]

The passage begins with Carlos repeating his wife Lena's injunction to not expect company that evening. The words, which were proffered earlier in the day and interrupt Carlos's wait but supplement his train of thought, are placed in italics - indicating, perhaps, that the utterance originates from outside of the very present moment. The parenthetical third line conveys one of Carlos's background actions - his futile counting down to the moment his brother and sister arrive - which interrupts his own narration, coming between the second and fourth lines. Similarly, the fifth line cuts through the utterance that composes the fourth and sixth lines. '[C]omo ela teima' ['as she insists'] points toward a repetition that occurs at various points in time - Lena's insistent reminders that he expelled his siblings from their apartment in Lisbon (located in the Ajuda neighborhood/civil parish) and from his life. Rather than inserting this short adverbial clause within the larger one by way of a comma, Antunes renders Carlos's fragmented narration by breaking the clauses into three separate lines. The empty spaces before and after each clause stand for the discontinuities at the heart of the postcolonial subject's attempt to place the past in a unified signifying chain.

The italicized utterance constituting lines eight and nine is Carlos's own from the colonial past. While describing Lena's non-European clothing, he is confronted by his own words - ones that he used to legitimize his teenage romance with Lena, a mixed-race resident of Malanje's shanties, to his white schoolmates and family. In reproducing his own discourse from the past, the listeners of that utterance are also present at the time of narration. Through this spectral invocation of colonial gatekeepers of whiteness, the reader is 
made aware that the racial signifiers of colonialism follow Carlos from the past to the present, thus framing the memory of his traumatic experience of racial meaning in the colony. As Medeiros argues, 'postcolonial time is always already unhinged, [...] it does not come after, as its prefix would suggest, but rather is always there from the beginning of colonialism and as such marks the colonizer as much as the colonized' (44). The colonial field of meaning is thus not temporally bound. If the formation of signifiers of race, gender, class, and sexuality dialectically predate colonial encounters, they continue to inform contemporary forms of economic and political power. The narrators of the novel are thus cognitively incapable of containing colonial discourse within the false temporal confines of colonial settlement. The enunciative voices of this discourse also resist confinement. As Isabela Figueiredo repeats regarding her father (see the previous chapter), these voices are colonialism. In Carlos's marriage to Lena, the collective experiences of colonialism continue to impact his affective existence - the discourses of whiteness and imperial power's need/desire to reproduce it persistently frame how he experiences both love and the institution of matrimony.

Carlos and the other narrators (perhaps to varying extents due to their differing access to colonial privileges) can thus be thought of as postcolonial figures that reflect on the discourses of colonialism and present the speaking corpses of the colonial past - the 'then' which is always 'now.' As in many of Antunes's works, narrational agency is decentered. One can argue that the four narrators in O Esplendor de Portugal are not always telling a story - they are, instead, haunted by it. It is the story, and the spectral voices contained therein, that tell them; the story, the inner crypt of colonialism, in which they are also characters. The ghostly voices speak the discourses of colonial power that informed their previous existence as settlers.

Spectral voices intervene and foil the narrators' attempt to forge a coherent signifying chain of the past that would enable them to dwell as complete, fully functional subjects in the present. Medeiros thus reads the plight of the narrators as a futile attempt to reconstruct postcolonial selves. The narrators labor to piece together the postcolonial ruins of Empire - its discourses, bodies, and voices - in order to render a cohesive identity. The challenge is to reorder the signifiers of the past into a signifying chain in which individual identity can then be enunciated. Like the post-imperial metropolis's imperative of forging an outer crypt that resignifies its inner counterpart, these former colonists seek to articulate their own outer narrative - looking to accommodate the ghosts by taming them through yet another layer of narrativization in order to exist in the postcolonial present.

The narratological style of the novel arguably occupies an interstitial place in the thought/writing binary. In presenting a written schema of the 
subject's interior monologue - interior dialogues, in fact - Antunes seems to labor toward a visualization of thought. This would be a chain of words not marked by standard punctuation rules. Rather than conveying interruption through a graphic mark such as a comma or period, Antunes utilizes the opposite of written presence - a blank space that leads to another line of text, usually occupied by another voice. While the comma or period is a present mark that conveys a temporary absence of speech, Antunes conveys the absence of speech - interior or otherwise - through an absent mark. But this blank space is never completely empty or disconnected from textual presence. It signals a trace from the past that will soon come into the reader's view of the text. In other words, the blank space is the cognitive mechanism by which another voice can produce its presence.

Paula Gândara sheds light on the complexity of the novel's narrative process by approaching it as if 'Carlos, Isilda, e até mesmo Clarisse e o próprio Rui se deitassem no divă e fizessem do leitor o terapeuta ideal' ['Carlos, Isilda, and even Clarisse and Rui were lying on the couch and addressing the reader as their psychologist'] (180). While the metaphor is an intriguing way of understanding the novel and the challenges faced by its protagonists/narrators - as analysands, they are indeed looking to rebuild a signifying chain - it does not adequately take into account the ghosts that also sit on the reader/analyst's sofa. After all, the voices of the narrators are not only interrupted by each other, but by myriad family members and other passing but impactful characters. In many instances throughout the novel, these utterances are not voiced through the narrator's memory as words that were once spoken to them. Rather, they are the reflections, critiques, and condemnations spoken directly by other characters who are presumably dead while the narrator is suspended in thought.

These moments of interrupted narration can be considered examples of what Sérgio Paulo Rouanet calls 'immobilization' in reference to Laurence Sterne's The Life and Opinions of Tristram Shandy, Gentleman and Machado de Assis's Posthumous Memoirs of Brás Cubas (90). As a narratological technique, a narrator or character is frozen in the middle of an action - including that of narration - while another action takes place, or while another ghost speaks. Where one narrator speaks in the aforementioned works of Assis and Sterne, constantly interrupting and immobilizing characters to the point of compromising the reader's trust, the narrators of $O$ Esplendor de Portugal are immobilized by external voices that may reside within or outside the narrator's psychic dwelling. While Tristram Shandy and Brás Cubas aim 'to be the master of time' in their reconstructions of a totalized signifying chain of past events, Isilda, Carlos, Rui, and Clarisse are barred from any form of mastery. Whereas Shandy and Cubas are narrators 
who immobilize characters for the sake of strategic yet seemingly errant digressions, it is the narrators of $O$ Esplendor de Portugal who are left immobilized by the characters whom they accidentally yet inevitably conjure as specters.

In many instances, immobilization works in tandem with another narratological device which Rouanet highlights in Sterne and Assis - 'delay' (94), pertaining to revelations brought forth by the intervening specters of o Esplendor de Portugal. Delays are central to the novel's narration through the frequent and seemingly uncontrollable digressions of the narrators and the interruptions of the ghostly voices. In the moments where the voices of a specter and the narrator intertwine, each delays the utterance - and its completion - of the other. In some cases, this means the delay of a particular revelation. The most impactful example of such a delay occurs during a chapter narrated by Isilda in which her own voice from the past interrupts her attempt to piece that past together. It is at this moment that the reader learns that Carlos is not Isilda's biological son:

(o meu filho Carlos a achar que eu não gosto dele por)

se deitou nas pregas de cetim, poisou a nuca na almofada, arranjou o lençol, fechou os olhos

[...]

- Năo escutes

(o meu filho Carlos, o mais velho, o primeiro dos meus filhos e Deus sabe o que me custou aceitá-lo, aquele que toma conta dos irmãos em Lisboa e acha que eu não gosto dele por)

o meu pai a dirigir-se comigo para a casa da fazenda na época em que a fazenda e a casa e os espelhos e eu éramos novos [...]

- Não tínhamos outra solução que não fosse enterrá-lo também antes de Luanda o enterrar a ele e a nós o senhor sabe que não tínhamos outra solução

(eu não ser mãe dele). (Esplendor 89-90; emphasis original)

[(my son Carlos thinking that I do not like him because)

lay down on the satin folds, placed his head on the pillow, fixed the sheet, closed his eyes

[...]

'Don't listen'

(my son Carlos, the oldest, my first and Lord knows how difficult it was for me to accept him, he who takes care of his brother and sister in Lisbon and thinks I don't like him because) 
my father going to the plantation house with me at a time when the plantation and the house and the mirrors and myself were all young $[\ldots]$

'We had no choice but to bury him before Luanda would bury him and us Lord knows we had no other choice'

(I am not his mother).]

This passage also details the complexity of the novel's spectrality, as one that also implies an intermeshing of time. The characters of the past emerge in the present and show up in the future, surveying how time is being narrated. Their utterances infiltrate the narration, furnishing footnotes to the discourse of the subject. We can, therefore, think of each character as a history of the subject - an unstable entity that repeatedly emerges in different forms at different moments. As a palimpsest of selfhood, the subject in the novel is confronted by its own emergence and articulation situated in different moments. These different layers of the palimpsest, marked by the discursive and material conditions of a particular moment, are inevitably present at the moment of the narrator's latest inscription.

In recalling his journey to find his biological mother in Cotonang, Carlos angrily recalls confronting a woman he was convinced was his mother. His father Amadeu interjects throughout this particular recollection, inserting his own signifying chain into that of Carlos:

[eu] a obrigá-la a encarar-me, a perguntar baixinho, numa raiva que crescia e crescia e me impedia de bater-lhe

- $\mathrm{O}$ teu filho?

uma rapariga, uma miúda comprada à família pelo preço que eu quis dado que se não pode recusar uma mulher a um branco

[...]

- O teu filho?

$[\ldots]$

eu ainda não era um bêbado, um palhaço, ainda não com a minha mulher a dormir com o comandante da polícia no escritório por baixo do meu quarto sem se esconder de mim ou se ralar comigo, eu a apanhar o gargalo da mesinha de cabeceira a fingir que não dava fé, a quem o enfermeiro mostrava as análises do figado e as radiografias da vesicula que em vez de me assustarem me alegravam, a prevenir-me da minha morte, dos vómitos de sangue, da icterícia, das úlceras, das dores, da febre, eu contente imaginando o rebentar das azáleas e as flores das acácias, a minha filha Clarisse a visitar-me aos sábados na casa da minha sogra, da minha mulher, dos filhos da minha mulher, não do meu filho, não minha visto que a minha casa é uma cabana no bairro da Cotonang, em Malanje 
[...] meu filho Carlos, espantei-me do meu filho Carlos, senti-o mexer-se quando the toquei, o meu filho Carlos

- Onde vais com a furgoneta Carlos?

- Tenho um encontro com um intermediário em Malanje amanhã sem falta estou cá

que foi a Malanje e regressou de Malanje sem achar qualquer resposta para além de uma mulher embalsamada nos seus cheiros amargos, o meu filho Carlos. (Esplendor 133)

[I made her face me, asking quietly, in a rage that grew and grew and stopped me from hitting her

'Your son?'

a young woman, a girl purchased from her family at the price I desired since no one can refuse a woman to a white man

[...]

'Your son?'

[...]

I was not yet a drunkard, a clown, my wife was not yet sleeping with the police chief in the office under my room without hiding from me or being bothered by me, me grabbing the bottle from my night table pretending I had no idea, I whom the nurse would show liver tests and gallbladder $x$-rays that instead of scaring me pleased me, warning me of my death, of the bloody vomiting, of the jaundice, of the ulcers, of the pains, of the fever, me happy imagining the budding of the azaleas and the acacias, my daughter Clarisse visiting me on Saturdays in the home of my mother-in-law, of my wife, of my wife's children, not of my son, not mine seeing that my house is a cabin in the Cotonang neighborhood, in Malanje [...]

my son Carlos, I was shocked by my son Carlos, I felt him move when I touched him, my son Carlos

'Where are you going with the van Carlos?'

'I have a meeting with a businessman in Malanje, I will be back tomorrow for sure'

who went to Malanje and returned from Malanje without finding any answers aside from a woman embalmed in her bitter smells, my son Carlos.]

Amadeu, an abject figure degenerated according to the discourses and expectations of colonial whiteness, supplements or adds a footnote to Carlos's utterances. Amadeu's interjection first situates him, his subject-position, within the colonial field of meaning as an individual initially interpellated to carry out imperial power on the colonial 'ground,' but who was unable to follow the identitarian mandates of that interpellation. Part and parcel of 
the colonist identity, in other words, was the performance of the imperial mandates explored in the previous chapter in relation to Figueiredo's Caderno de Memórias Coloniais, especially the trans-generational formation of the white colonist family. Procreating with an African woman is merely the beginning of his degradation in colonial time and space. As a colonist father, the gendered aspect of his mandate implies the power to bring children into the familial realm. In this regard, Isilda displaces his imperial masculinity by purchasing Carlos and bringing him into the family sphere. Moreover, Amadeu's masculinity is always already compromised by his working-class origins and then furthered by his marginal colonial existence.

Rather than residing in the (petit) bourgeois colonist spaces of the compartmentalized colony, Amadeu resided in a neighborhood of prefabricated buildings and small apartments owned by the cotton plantation and manufacturer, Cotonang, for which he worked. As an agronomist, he was responsible for helping establish the material conditions for colonist living and privilege, but without fully partaking in the colonist experience. His mandate was not to establish whiteness through a project of family-building. Isilda recalls that the agronomists of this neighborhood 'preveniram-me que todos os agrónomos da Cotonang sem excepção tinham mulatas e filhos mulatos com quem viviam em segredo no bairro da empresa' ['warned me that all the agronomists of Cotonang without exception had mulatto women and mulatto children with whom they secretly lived in the company's neighborhood'] (Esplendor 57). In many ways, then, Amadeu does not fit the family-centered mold of colonist whiteness embodied by Isilda's family.

A later passage narrated by Isilda gets to the crux of colonist identity. The decision to migrate, to buy into the colonial promise of prosperity is bound to the desire to escape non-bourgeois otherness within the metropolis and to gain access to the right to signify transnational, imperial Portugueseness. Propaganda about working in the colonies, to ultimately foment and guarantee the financial well-being of the imperial metropolis, was packaged to the urban and rural working classes as an expedient means to attain bourgeois selfhood (Castelo 2007), a politicized interpellation into universal Europeanness. Residing in the colonies represented the blank page of History to which Toni Morrison refers in Playing in the Dark (35), enabling citizens who were marginal within metropolitan social organization to transcendentally inscribe themselves. In the colonies, the marginal metropolitan can respond to Empire's desire for its reproduction by taking up an intersubjective place of writing and power within its system of differences. As Isilda relates in O Esplendor de Portugal, Empire fuses metropolitan class divisions with colonial otherness to form a complex spectrum of subject-positions: 
O meu pai costumava explicar que aquilo que tínhamos vindo procurar em África náo era dinheiro nem poder mas pretos sem dinheiro e sem poder algum que nos dessem a ilusão do dinheiro e do poder que de facto ainda que o tivéssemos não tínhamos por não sermos mais que tolerados, aceites com desprezo em Portugal, olhados como olhávamos os bailundos que trabalhavam para nós e portanto de certo modo éramos os pretos dos outros da mesma forma que os pretos possuíam os seus pretos e estes os seus pretos em degraus sucessivos descendo ao fundo da miséria, aleijados, leprosos, escravos de escravos, cães, o meu pai costumava explicar que aquilo que tínhamos vindo procurar em África era transformar a vingança de mandar no que fingíamos ser a dignidade de mandar, morando em casas que macaqueavam casas europeias e qualquer europeu desprezaria considerando-as como considerávamos as cubatas em torno, numa idêntica repulsa e num idêntico desdém, compradas ou mandadas construir com dinheiro que valia menos que o dinheiro deles, um dinheiro sem préstimo não fora a crueldade da maneira de o ganhar e para todos os efeitos equivalente a conchas e contas coloridas. (263)

[My father would explain that what had brought us to Africa was not the pursuit of money or power but of blacks without money or power who would give us the illusion of money and power because even though we had it, we did not, for we were nothing more than tolerated, accepted with disdain in Portugal, looked down upon as we would look down upon the Bailundos who worked for us and, therefore, in a way, we were blacks in the eyes of the metropolitans in the same manner that blacks possessed their own blacks and these their own blacks in successive degrees descending to the base of misery, the invalids, the lepers, the slaves of slaves, dogs, my father would explain that what we searched for in Africa was the transformation of the vengeance of power into what we pretended to be the dignity of power, living in houses that mimicked European houses and that any European would ignore, considering them as we would consider the huts around us, with an identical repulsion and identical disdain, purchased or erected with money worth nothing save for the cruelty through which it was earned and for all intents and purposes equal to seashells and colored beads.]

The dizzying, one-sentence stream of consciousness stylizes the anxious retelling of Isilda's father's interpellation into Empire, particularly through the promise of social mobility in the move from metropolitan rural life into 
colonial space, from European peasant to colonist. The passage also reveals what Gayatri Chakravorty Spivak would call the 'un-coercive rearrangement of desire' that is central to particular forms of education, especially those central to Empire. Colonial propaganda carries its own educational purpose which is not always so un-coercive, namely to align individual desire with imperial desire through interpellation into bourgeois images of selfhood. This version of bourgeois whiteness revealed by Isilda's father, Eduardo, himself a specter, underscores the ideal ego's need for its phantasmatic inversion - non-white, non-bourgeois bodies. For Eduardo, though, this is not a dichotomy of power elaborated by one version of self and a malleable other. Rather, this outline of imperial relations is revealed as a spectrum of otherness at one end of which resides metropolitan whiteness and at the other the colonized rural peasantry. The fantasies of otherness, meanwhile, are the logic by which exploitation and identitarian performance are carried out.

As an agronomist, Amadeu is not interpellated into colonial space in the manner of Isilda's parents. His presence is not for the direct consolidation of whiteness. Unlike the emigrating metropolitan family, he serves the corporate entity for which he works more directly. In terms of residence within compartmentalized colonial space, he lives in temporary housing close to Malanje's shantytowns. Residential divisions sought, of course, to reinforce the colonial divisions of bodies and labor. As we saw in the previous chapter, in the case of Isabela Figueiredo's father, white male heads of family possessed the privilege of traversing such divisions. In other words, familial versions of white masculinity were able to negotiate between the sexual indulgence in African bodies deemed accessible and the consolidation of a white home and, subsequently, colonial privilege. The distinction between Amadeu's subject-position and that of Eduardo or Figueiredo's father is thus rendered by the different ways in which their desire has been rearranged in order to serve distinct imperial purposes.

Since the agronomist subject-position appears to be variably incompatible with the construction of the white colonist family, Amadeu's interracial sexual liaisons are more difficult to narrativize into the family's signifying chain. Isilda is thus left in charge of negotiating Amadeu's sexual actions vis-à-vis the mandates of her white patriarchal family. As an image of failed whiteness according to Isilda's colonist family values, Amadeu is permanently displaced from this process, and subsequently from the family itself. His failed whiteness also spells the trauma of failed masculinity, leading to his remaining existence as drinking himself to death.

Unsurprisingly, Isilda's power to resignify Amadeu's sexual actions into a familial narrative intersects with colonial economic power - that 
of purchasing Carlos, the product of her husband's interracial sexual relationship with Carolina. Such financial prowess, of course, takes on gendered meanings, as the performance of masculinity so often intertwines with the privileged performances of capital and wealth. This brutally emphasizes Amadeu's inability to assume the ideal ego of colonist masculinity embodied by Eduardo, despite the latter's own latent anxieties as evidenced in his theorization of metropolis-to-colony migration and its concomitant promise of social mobility. In this regard, Amadeu can even be thought of as a specter in life, perhaps in line with the zombie trope, a lifeless body devoid of a functional subjectivity. His integration into the family space is eventually limited to being shut away in his bedroom, isolated from the rest of the house, gradually erasing his physical existence through alcohol consumption.

\section{The Spectral and the Specular}

Carlos's placement in the family is not simply the consequence of interracial sex, or of an interracial relationship gone awry. He experiences his familial place as an identitarian tragedy also because of the complexities and power dynamics that informed his faulty membership in the colonist family. Carlos's experience as a mulatto child in a colonial setting underscores the many oversights and contradictions and the ignorance of Freyrean narratives of interracial love. Even if one were to remove colonial power dynamics and the colonial meaning through which the black female body is repeatedly and malleably rendered, and to argue for some kind of emotional bond between Amadeu and Carolina, the mixed-race family is far from desired. In O Esplendor de Portugal, it is essentially barred from existence. Not only are black bodies deemed unfit for family life, and more suitable for labor and sexual exploitation, the black family can be taken apart and its members confiscated. The mixed-race child, romanticized in much Lusophone literature and cultural/intellectual production as a symbol of cultural syncretism, is more concretely a battleground over which colonial power is performed and reproduced.

Carlos's body becomes the significational site where Isilda and Amadeu can perform their colonial power and inscribe their identity. In this intramarital struggle for bourgeois identity, Isilda is ultimately victorious as she delineates the roles of both Carlos and Amadeu within the family and the colonial space. Narrativization of the familial domain, a paternal function in Caderno de Memórias Coloniais, is thus taken up by Isilda in Esplendor. In stripping Amadeu of this imperial/masculine agency, he is fundamentally relegated to the margins of colonial articulation. 
Carlos is well aware that his body is signified from without, through the colonial field of meaning as it is rendered in the family circle. He experiences this external signification, in itself, as a form of haunting, as if another figure inhabited his name. It is through such an implied specter in the realm of identity that he eventually comes to realize the colonial splitting of his ego - a traumatic experience in and of itself. Immediately following Amadeu's spectral interruption above, Carlos reflects on his name, the signifier into which he was interpellated:

dizia o meu nome

Carlos

e eu era diferente daquele nome, não era aquele nome, não podia ser aquele nome, as pessoas quando chamavam

Carlos

chamavam um Carlos que era eu em elas não eu nem era eu em eu, era um outro, da mesma forma que se lhes respondia não era eu quem respondia era o eu deles que falava e o eu em eu calava-se em mim e portanto sabiam apenas do Carlos delas não sabiam de mim e eu permanecia um estranho, um estrangeiro, um eu que era dois, o deles e o meu, e o meu por ser apenas meu não era e então dizia como eles diziam

Carlos. (Esplendor 127)

[I would say my name

Carlos

and I was different from that name, I was not that name, I could not be that name, people when they called

Carlos

would call a Carlos that was me in them not me nor the me in me, it was someone else, in the same way that if I replied it was not me that would reply it was their me that would speak and the me in me would remain quiet in myself and therefore they knew only of their Carlos, they did not know me and I remained a stranger, a foreigner, a me that was two, theirs and mine, and mine because it was only mine did not exist and thus I would say as they said

Carlos.]

Carlos's reflection essentially takes us back to the mirror stage, undoing layers of subjectivation and bringing us to the incipient moment of the subject. The totalized image he sees in the metaphoric mirror is the place he is to occupy in the realm of imperial power. It is a narrative of body and 
selfhood articulated through and for the imperial field of meaning. His interpellation into the image serves to reproduce the colonial structuring of power - its taxonomies and social organization - and perhaps more viscerally for him, the race-based privileges and power of his adoptive family. When summoned or spoken to, Carlos realizes that those individuals who occupy his symbolic realm of existence - the colonial field of meaning - are interacting with the imago/specular image of identity constructed by them. After all, his interpellation into the colonial field of meaning occurs through the family space, which is controlled, though not exclusively, by Isilda. The narrative/image that is Carlos is the result of a colonial economy of desire. Those who inscribe the image and interpellate him into it are imperial subjects answering Empire's desire for reproduction.

By means of this interpellation, Carlos's skin color and parental history is given meaning through the colonial discourse of race. The family space - directed by Isilda - functions as a sort of metonymy of the larger colonial sphere into which it is inserted. More crucially for Carlos, however, it is a pedagogical space, embodied especially by the physical confines of the colonist house, where he will learn to be a subject of color to the colonial realm of meaning. In the moment of narration, Carlos remembers how control over the domestic space served to place him racially within the colony's social organization. Carlos specifically recalls the frequent gatherings of foreign investors and colonists at the home:

os belgas enchiam-nos o vestíbulo de malas e ficavam uma semana a beber com o meu pai no terraço, a caçar jacarés na Chiquita, a usar fraque ao jantar como as mulheres deles penteados barrocos, o relógio aumentava de importância, os meus irmãos e eu comíamos num compartimento à parte por não haver lugar à mesa para nós e um dia percebi que não era por não haver lugar à mesa nem pela Clarisse nem pelo Rui era por medo que os estrangeiros reparassem que eu năo era branco, era preto como os contratados, mal aparecíamos na varanda cheia de senhoras sentadas a tomarem chá, de capacete colonial e botas de montar, fitando-nos num horror delicado, a minha mãe levantava-se logo abrindo as mangas a esconder-me, mandando-nos brincar para o jardim [...] a minha máe que se a Clarisse ou o Rui entravam sozinhos na varanda os chamava, os deixava ficar, os mostrava às convidadas e se era eu as bochechas lhe caíam como se perdesse malares e me enxotava numa lufa-lufa antes que pudessem ver-me. (Esplendor 130)

[the Belgians would fill our vestibule with luggage and would stay a week drinking with my father on the deck, hunting alligators in 
Chiquita, wearing coattails for dinner and their wives sporting baroque hairstyles, the clock grew in importance, my brother, sister, and I would eat in a separate room because of the lack of space at the table for us and one day I understood that it was not due to lack of room at the table nor due to Clarisse nor due to Rui, it was out of fear that the foreigners would notice that I was not white, that I was black like the employees, as soon as we would appear in the veranda full of women seated drinking tea, in colonial helmets and equestrian boots, looking at us in delicate horror, my mother would get up immediately opening her sleeves in order to hide me, ordering us to play in the garden [...] my mother who, if Clarisse or Rui entered the veranda alone, would call them, would let them stay, would show them to the guests and if it were me her cheeks would fall as if she had lost her molars and she would shoo me away before they could see me.]

The frequent colonial gatherings become the stage upon which social organization is collectively performed. It is also the stage upon which Carlos comes to (mis)recognize his place within Empire as a mulatto boy who must be barred from participating in white colonial pageantry as well as its pleasures and privileges. His remembering of so many details, from hairstyles to footwear, communicates the series of contrasts that define the colonial circulation of meaning and the definition of separated spaces those for the colonist and those for the colonized. As the house stands for bourgeois existence (objects and white bodies), Carlos's foreclosure from that space posits his racialized body as the antithesis of colonial whiteness. As such, he learns to occupy a liminal space, within both the family and the colony. From that moment of signified difference on, young Carlos experiences the family domain from a perpetually ambivalent subjective place. At the moment of narration within the novel, Carlos begins to piece together the moments of the colonial past that culminate in his spectral experience of subjectivity as a being-for-Empire, the imperial field of meaning and the subjects that constitute it.

In being-for-Empire, Carlos is a signifier in the imperial signifying chain. It is no wonder, then, that the last passage eventually leads to his critical reflection on his name - the pure linguistic signifier. The signifier is occupied by an other that is not he; an other that occupies the strategically liminal location within the colonial field of meaning. The haunting core of subjective existence within the imperial symbolic realm, as an experience of split selfhood, gestures toward a decolonial notion of the subject. In identifying the Carlos that is not he, he enunciates, and speaks from, a subjective place tentatively outside of the colonial realm of articulation in which his family 
resides. The gesture toward a subjective existence embedded in another symbolic realm is paradoxically emancipatory and traumatically painful, as it requires the shattering of a particular mode of being founded upon the illusions of imperial power. In many ways, the move toward the outside of Empire is already under way for Carlos, driving his narrative objective of constructing his own signifying chain of the past and the present within which to reside.

Carlos's spectral understanding of the subject offers us a theoretical framework for grappling with both the other narrators of the novel (and their need to narrate) and the formation of the colonist subject. Like Carlos, throughout her fragmented and trans-temporal narration Isilda also confronts the spectral image of her subject-position within Empire the narrative of herself that emerges in the colonial field of meaning. The interpellating subjects that inhabit said field of meaning subsequently regulate her relationship with her body and her specular image. She frames her relationship with her parents in this light. More specifically, she understands parental love to be contingent upon her adherence to the subjective contours of this image, the ideal ego, which is external to her. In many ways, it is not she who possesses the love of her parents, but this specter that is unattainably other to her. She consistently recalls repeatedly asking loved ones, especially her parents, if they 'gostavam de mim' ['liked me'] (Esplendor 414).

Approaching death at the hands of either Unita rebels or MPLA state counter-rebel forces (Isilda does not offer a clarification) in the final pages of her narration, she recalls once more her search for parental affection, a search that would perhaps bridge the abyss separating her from her spectral specular image:

se puxava o lençol da minha mãe a meio da noite

- Gosta de mim?

não me abraçava, não me dizia

- Anda cá

não me deitava na cama com ela

não era dinheiro, não poder, pretos sem dinheiro e sem poder algum sentava-se estremunhada, acendia a luz para verificar as horas, o cabelo como nunca tho vira [...] a casa uma caverna onde os reposteiros acenavam grandes asas lentas

$[\ldots]$

- Gosta de mim?

não chego ao alto dos tremós, a minha mãe de luz apagada a ir-se embora

- Que pergunta. (Esplendor 409-10) 
[if I pulled on my mother's bed sheet in the middle of the night

'Do you like me?'

she wouldn't hug me, wouldn't tell me

'Come here'

I wouldn't lie in bed with her

it was not money, not power, blacks with no money and no power

she would sit up disturbed, would turn on the lamp to check the time, her

hair like I had never seen it (...) the house a cavern where the drapes waved like large slow wings

(...)

'Do you like me?'

I cannot reach the top of the furniture, my mother with the lights off leaving

'What kind of question is that'?]

Through her parents, Isilda is repeatedly estranged from this image. Her parents' implied rejection of her in attempting to follow their desire embodied in the specular image - renders her other vis-à-vis the specter/ image that possesses their love. The specter is thus the metaphysical materialization of Empire's desire - in her case, surveyed by her parents.

This predicament is not, however, unique to Isilda. It is therefore no surprise that her father's critical utterance on the colonist's socioeconomic - and subsequently identitarian - mission in the colony creeps into this moment of her narration. The spectrality of specularity informs all three generations of Isilda's family. The specular image, embedded within a spectrum of power as an ideal, must inherently reproduce the spectrum. It aligns individual desire with power's desire. The desire for individual success and notions of it - here bourgeois social mobility through colonial migration - is circuited to reproduce Empire's wealth, privilege, and field of meaning. Eduardo, Isilda's father, like the novel's four narrators, retroactively confronts the colonist experience by splitting the colonist subject he was/is. This psychoanalytic interrogation brings them back to the edge of the Lacanian symbolic order - the Imaginary order where the individual in the process of interpellation is still a distinct entity from the specular image.

This is a return to the fundamental confrontation in the emergence of the subject. Colonial reality, what became the inner crypt of Portuguese imperial narrativization, is not only occupied by specters when we retroactively approach it as a past reality. Rather, o Esplendor de Portugal's narrators gesture toward the conclusion that colonial reality - the ideological maintenance of power's authority over bodies, space, and commodities - is constructed through specters of selfhood. In order to be a productive subject for the 
imperial field of meaning and respond to its desire, the individual must become one with the specter that is the specular image.

Isilda's confrontation with her identitarian specter - repeatedly played out through the search for her parents' love - is finally elided in the novel's last lines, seconds before she is killed:

fixavam-me com a mira, desapareciam atrás das armas, o modo como os músculos endureceram, o modo como as bocas se cerraram e eu a trotar na areia na direçáo dos meus pais, de chapéu de palha a escorregar para a nuca, feliz, sem precisar de perguntar-lhes se gostavam de mim. (Esplendor 414)

[they set the crosshairs on me, they disappeared behind the weapons, the way in which their muscles hardened, the way in which their mouths would close and I would trot toward my parents' house, with my straw hat slipping down my head, happy, without needing to ask them if they liked me.]

As she drags herself through Angolan postcolonial terrain ridden by civil war, a scene from her childhood - with her parents - is restaged one last time before the bullets presumably hit her. In that brief moment, the death of the specter/specular image comes just before her own. The specter's demise results from the end of colonial meaning for Isilda - the significational field that has informed her life in Angola. If there is no longer a field of colonial meaning in which her life is inserted through racial and socioeconomic privileges, there is no longer a need for her to seek the voicing of her parents' love. But Isilda cannot live outside of such a field and must ultimately die. In many ways, her insistence on staying in postcolonial Angola and keeping what remained of her family's possessions had already posited her as a sort of ghost, a trace from the colonial past that merely witnesses the disintegration of the physical manifestations of colonial privilege. It was thus as a speaking/narrating ghost of the past that she experienced the other ghosts of the past, including her own identitarian specter. With her impending death, all is exorcised for her.

\section{Spectrality and Ruins at the Heart of Colonial Spaces}

The novel's narrative structure underscores the importance of spectrality - corpses and ghosts - in understanding the colonial past and, more importantly, its retelling in the present. Isilda notes early in the novel, when reflecting on young Carlos's paranoid obsession with the house's wall clock, that: 
O meu filho Carlos, em criança, julgava que o relógio de parede era o coração do mundo e tive vontade de sorrir por saber há muito que o coração do mundo, o verdadeiro coração do mundo náo estava ali connosco mas além do pátio e do bosque de sequoias, no cemitério onde no tempo do meu pai enterravam lado a lado os pretos e os brancos do mesmo modo que antes do meu pai, na época do primeiro dono do girassol e do algodão, sepultaram os brancos que passeavam a cavalo e davam ordens e os pretos que trabalharam as lavras neste século e no anterior e no anterior ainda. (Esplendor 83)

[As a child, my son Carlos believed the clock on the wall was the heart of the world and I felt the urge to smile because I had long known that the heart of the world, the real heart of the world, was not there with us but beyond the yard and the sequoia woods, in the cemetery where in my father's time they would bury blacks and whites side by side in the same way that before my father, in the time of the first owner of sunflower and cotton, they buried the whites who traveled on horse and gave orders and the blacks who worked the fields in this century and in the previous and the one before that.]

The cemetery is the metaphorical heart of the colonial field of meaning in which Isilda resides with her relative power and privilege. The cemetery stands for the dialectic of bodies - those that gave orders and those that followed them. These were, of course, signified bodies upon which colonial power was constructed. Isilda begs the novel's implied postcolonial reader not to separate the present moment from the palimpsest of power written by and over bodies that have filled colonial time and space. More crucially, though, these very bodies serve as reminders of that connection, and that the inner crypt of imperial narrativization can disrupt the outer crypt's drive to silence it.

From the nearby cemetery, Isilda hears voices:

dizendo palavras que eu entendia mal por medo de entender, năo o vento, não as folhas, vozes que contavam uma história sem sentido de gente e bichos e assassínios e guerra como se segredassem sem parar a nossa culpa, nos acusassem, repetindo mentiras, que a minha família e a família antes da minha tinham chegado como salteadores e destruído África. (Esplendor 83-84)

[saying words that I misunderstood out of fear of understanding, not the wind, not the leaves, voices that told an illogical story of people and animals and murders and war as if they incessantly whispered our 
guilt, accused us, repeating lies, that my family and the family before mine had arrived as thieves and destroyed Africa.]

We can already witness in this colonial moment the formation of an outer crypt beginning to surround the cemetery - a very literal crypt. This outer crypt is, more precisely, the re-narrativization of the stories told by the cemetery. In the passage, Isilda wants to understand the history told by the crypt as 'repeated lies'; a desire that one can connect to the 'fear of understanding' the voices, for these may compromise how the subject relates to the larger imperial field of meaning. For each subject-position there is a series of voices that articulate the emergence of said subject-position. This is an articulation that, more than explaining the history of the subject, can ultimately unsettle the subject by corroding the signifying chain/version of History into which the colonist subject is placed.

In order to reconsolidate identitarian totality within the imperialized field of meaning pertaining to colonial time and space, the utterances from the crypt are reinterpreted as 'lies' - a psycho-hermeneutic project carried out especially by Isilda's father. She recalls that he used to warn her about the voices: 'Não ouças' ['Do not listen'] (Esplendor 84). The directives to ignore, filter, and resignify the voices from the crypt underscore how colonist reality is already contingent upon its own construction as an outer crypt.

Rather than approaching the cryptonomy of imperial narrativization as a relationship between an inner crypt and an outer crypt, the myriad overlapping and mutually interrupting voices, narrators, specters, times, and places in $O$ Esplendor de Portugal point toward the trans-temporal formation of imperial meaning and power as a series of crypts. It is here that Antunes's spectrality goes beyond that deployed in Figueiredo's memoirs. Within one inner crypt there reside others. Here imperial cryptonomy is fundamentally a layering of different crypts and narratives. For instance, metropolitan historicization resignifies the cryptic voicing of Eduardo's resignification of the cemetery's voiced utterances. Similarly, the voices that speak from the cemetery are themselves in significational dialectic, challenging the signifying chain of the others. In this regard, the cemetery as a place of interrupted narratives resembles the collection of characters in the novel's narrative edifice. As with the cemetery in relation to Isilda, the voices from the book disquiet and disturb the subject that is exposed to them - the present-day postcolonial/imperial reader, particularly that which resides in the outermost crypt of contemporary metropolitan historicization.

Tellingly, the house, the metaphoric location of outer cryptonomy vis-à-vis the cemetery as inner crypt, begins to erode, transformed into a structure 
rotted in colonial time and space. Isilda inevitably begins to vanish along with the house:

os meus passos sumiram-se do corredor, deixei de distinguir a minha sombra, as lâmpadas dos rostos nas molduras, fundidas, apagaram-se e entendi que os mortos começaram a morrer e a casa com eles, - esqueleto da casa com pedaços de cartilagens de reposteiros e de quadros suspensos dos ossos, o esqueleto da casa sem ninguém excepto eu, as criadas e a trepadeira da varanda a amortalhar-nos no seu lençol de insectos. (Esplendor 84)

[my steps disappeared in the hallway, I became unable to distinguish my shadow, the lamps from the faces on the frames, dissipated, they were extinguished and I understood that the dead began to die and the house with them, the skeleton of the house with fragments of cartilage of curtains and of picture frames suspended from the bones, the skeleton of the house with no one except me, the maids and the creepers of the veranda rolling us in their sheet of insects.]

As the outer crypt dissolves after the dissipation of Portuguese colonial presence, Isilda's body begins to wither away in a paranormal fashion, losing its physical presence - that is, her shadow. She becomes a ghost inhabiting a space that was erased by anti-colonial time. This process is under way from the novel's outset, as early as her 1978 letter to Carlos:

a casa mudara, conhecia os objectos e achava-os estranhos, conhecia as cadeiras e não me sentava nelas, o passado dos retratos nas molduras cessara de me pertencer, quem diabo é este, quem diabo é aquele, a senhora acolá de braço dado com o meu marido usa um chapéu que eu tive. (Esplendor 28)

[the house had changed, I recognized the objects and I found them strange, I recognized the chairs and did not sit on them, the past of the portraits in the frames had ceased to belong to me, who on earth is this, who on earth is that, the lady over there arm in arm with my husband is wearing a hat I once had.]

We can thus think of the house as a space under de-narrativization. Knowledge, the meaning which informs Isilda's relationship to the objects in the house, including the faces in the portraits, begins to break down. Without this imperial meaning, the house is left a structure of abject death conveyed via the tropes of bodily degradation. Stripped of all imperial 
signifiers, the house is reduced to a skeleton with broken pieces of cartilage buried by the vines that climb the house. If Isilda connects the voices from the cemetery to the wrestling of trees, leaves, and twigs in the wind (Esplendor 84), then the growing vines are tied to the inner crypt's erosion of the outer crypt.

The house's imperial death, the de-narrativization or emptying of meaning, of its colonial existence as outer crypt/site of imperial enunciation and gnosis, is ultimately a decolonial phenomenon. The reconfiguration of the cryptonymic relation between house and cemetery, between inner crypt and outer crypt, constitutes a fundamental 'delinking from coloniality, or the colonial matrix of power,' according to Walter D. Mignolo's conception of decoloniality (Darker Side xxvii). As the house metaphysically disintegrates, the disappearance of Isilda's shadow and physical body becomes a symptom of this decolonial dismemberment. The breakdown of the outer crypt at the hands of the inner crypt spells the destruction of the imperial link between the knowing subject and the known object, thus leaving Isilda in a psychic limbo. Without the cryptonymic existence of imperial knowledge, Empire's field of meaning, Isilda is stripped of her imperial life source - the signifying chain in which she exists. Subsequently, her body is left roaming the previously colonial space as a moving repository of imperial signifiers displaced from current postcolonial narrativization. As a partially lifeless repository, rather than inhabiting the postcolony, Isilda haunts the dead structure that is the colony, bringing her native former employee Maria da Boa Morte along with her through the deceased narrative.

In Antunes's cuvre, narratives, the outer crypts, are often structures approaching death and extinction. His works are arguably obsessed with the void at the core of ideology, and his plots are centered on peeling the layers of meaning to the point where we are left with (partially) de-signified violent actions and bodies in ruins. Antunes's plots are thus arguably experiments in ideological dissociation in which actions and bodies are unbraided from outer layers of meaning. As such, matter (human and otherwise) becomes lifeless. Colonial homes are returned to their purely biological existence as a conglomeration of altered building materials left to decompose, and human beings are once again 'featherless two-legged linguistically conscious creatures born between urine and feces whose bodies will one day be the culinary delight of terrestrial worms' (Cornel West in Taylor, Examined Life). 


\section{Decrepit Narratives and Decolonial Delinking}

The larger implications for reading Antunes against contemporary Portuguese imperial exceptionalism are thus centered on his articulation of death as a phenomenon that afflicts meaning, firstly, and individuals, secondly. After all, it is not so much the characters that die, but narratives that corrode. Characters, like readers, are left exposed to the inner crypts of the past, enjoined by the specters therein to reconceive their relationship with the present. In this regard, the novel, as Gould argues, 'exige tanto a reavaliação da auto-imagem nacional como a revisão do "esplendor do passado" ['demands as much the re-evaluation of Portugal's national self-image as a revision of the "splendor of the past"'] (Esplendor 154). Through the novel's staging of colonial spectrality, the significational framework of the postcolonial metropolis-nation also walks toward death. The nation, after all, is the novel's titular entity, and its epigraph is the example par excellence of the nation's outer crypt - Portugal's national anthem.

Cid Ottoni Bylaardt reads the epigraphic placement of the national anthem along similar lines, namely as the breaking of a national trans-generational signifying chain:

a voz dos egrégios avós ressoa no romance como um significante esvaziado de sentido, entre as brumas da memória, as quais, ao invés de atar o presente ao passado com um discurso hegemônico e consistente, conduzem ao estilhaçamento da História. (Esplendor 5)

[the voice of the egregious grandparents resonates in the novel as an emptied signifier, within the mist of memory which, instead of tying the present to the past by way of a hegemonic and consistent discourse, drives the shattering of History.]

Antunes thus presents the metaphoric house of the postcolonial metropolitan nation as the preface, only to execute its death via the spectral dwellers of its colonial inner crypt. The trans-generational collection of characters and specters in the novel profoundly compromises the integrity of the outer crypt, which constituted, for them, a false narrative.

While reading, the subject localized within the outer crypt - interpellated into the signifying field of contemporary Portuguese nationhood - is left, at best, like Carlos, looking to construct a new signifying chain from the past, or, at worst, like Isilda, aimlessly and lifelessly occupying a dying space. Reflecting on the role of literature vis-à-vis 'os desastres da história' ['the disasters of history'] (Esplendor 2), Ottoni Bylaardt points toward the rethinking of dominant historicization. The literary text thus 'permite 
o diálogo com o que poderia ter sido. o que pode parecer inimaginável torna-se, dessa forma, imaginável ao extremo' ['permits a dialogue with what could have been. What may appear unimaginable becomes, then, imaginable in the extreme'] (Esplendor 7). If we can locate historically marginalized voices and experiences under the 'unimaginable' - in relation to hegemonic historicity - novels such as O Esplendor de Portugal, Ottoni Bylaardt argues, can transform such experiences into 'hiperimaginável' ['hyperimaginable'] (1). He also associates the previously unimaginable with significational gaps that exist between the event/disaster and the historicization thereof. Antunes's novel thus renders hyper-imaginable the gaps, or omissions, left by the outer crypt. In this regard, by making the inner crypt hyper-imaginable, the novel not only addresses the postcolonial metropolis and the hegemonic modes of narrativization that reconceive its colonial past, it also moves toward decolonizing the metropolis.

The novel, as an artistic and ideological product, presents what Jacques Rancière has called 'the aesthetic regime of the arts,' 'a new regime for relating to the past [...] The aesthetic regime of the arts invents its revolutions' (Politics 25). For Rancière, the aesthetic regime emerges in opposition to the representational regime that establishes modes of seeing and doing (Bylaardt 11). The novel thus adopts a decolonial posture by positing itself as a new way of 'thinking and doing' (Mignolo, Darker Side 3) $v i s$-à-vis the outer crypt of postcolonial metropolitan historicization. We can apply Rancière's terminology from 'Ten Theses on Politics' to metropolitan historicization here, conceiving it as a 'political relationship that allows one to think the possibility of a political subject(ivity) [le sujet politique] not the other way around' (2). Politics, therefore, 'is not the exercise of power,' but the formation of the parameters by which subjects 'part-take' in 'the fact of ruling and the fact of being ruled' ('Theses' 2; emphasis original).

This political sphere - 'through which a subject is defined' (Rancière, 'Theses' 1) - implies a particular field of meaning that is constructed and policed. In his 'Theses,' Rancière theorizes this notion of the political sphere through a politics/police duality. The police is very much a trope for the ubiquitous and unlocalizable authority over meaning, over the ways in which subjects participate politically, here in the significational production of the postcolonial metropolitan nation. 'The police says that there is nothing to see on a road, that there is nothing to do but move along' ('Theses' 9). This force ultimately surveys and patrols how meaning is interpreted, enforcing the signification of what is sensible (seen, heard, smelled, touched, and tasted). It repeatedly solidifies the relationship between signification and power, by controlling the strategic relationship between signifier and signified. 
In the postcolonial metropolis, History is policed - and Empire is maintained through policing as historicity - by way of the monuments, intersections between sports and the imperial past, and ubiquitous cultural products romanticizing colonial relations. All of these envelop the temporally and spatially located postcolonial metropolitan subject, enjoining him to 'be Portuguese' by way of these imperial signifiers. Therefore, what is being policed is Portugueseness, in an imperial form, after colonialism. As much as these signifiers speak of the past, they function to mark the present, demarcating the parameters of subjective possibility. The policing of national subjectivity by way of imperial signifiers also places the subject into a global field of racial, gender, sexual, and economic signifiers.

Rancière's conception of the 'aesthetic regime' is very much a response to this policing function in relation to History. Offering a new regime for relating to the past, a potentially decolonial regime against the imperial signifying chain that surrounds and surveys the 'visible and the sayable,' ultimately propels political struggle:

The essence of politics, then, is to disturb this arrangement by supplementing it with a part of the no-part identified with the community as a whole. Political litigiousness/struggle is that which brings politics into being by separating it from the police that is, in turn, always attempting its disappearance either by crudely denying it, or by subsuming that logic to its own. Politics is first and foremost an intervention upon the visible and the sayable. ('Theses' 9)

António Lobo Antunes's intervention against the metropolitan policing of subjectivation in relation to History attempts to rearrange the relationship between 'the visible and the sayable' and the subject, the socially central relationship to be policed. Like the national anthem that opens the volume, the aforementioned signifiers (monuments, cultural products, etc.) that constitute the policing of subjectivation also form the outer crypt of Empire in the present after colonialism.

O Esplendor de Portugal thus proposes a rearrangement of this relationship through the corroding of outer crypts. As they dissipate and rot, the possibility for decolonial subjectivity arises, and may rearrange the metropolitan relation to the past. Drawing on both Mignolo and Rancière, the act of rotting narrativization and its policing function - here the outer crypt - moves toward 'unveiling the hidden geo- and bio-graphical politics of knowledge of imperial epistemology' (Mignolo, Darker Side 119). It is the unveiling of the racial, sexual, and economic politics that scars the novel's narrators and specters (the replacement of the outer crypt by the inner), 
that will dislocate the imperial policing of the metropolitan field of national meaning.

'Decolonial delinking' (Mignolo, Darker Side 119) must thus be undertaken as a global project, including the former metropolis. The decentering of the global North must also take place in the global North, where relationships to former colonies and placement within the global economy are negotiated and historicized. As such, more than a stripping of imperial meaning attributed to signifiers, they must be rearranged in order to undo the signifying chain of Empire. Furthermore, as global flows of capital bring migrant laborers, refugees, and tourists from the global South to cities in the global North, the signifiers that define the metropolis are in constant renegotiation. Carlos, the racialized colonial other turned migrant in the postcolonial metropolis, is the voice that arguably embodies this subaltern delinking. His subjectivation or placement into the imperial field of meaning as a child, the place from where he speaks, is incompatible with the contemporary outer crypt that seeks to resignify the inner, erasing its systemic violence.

As the subject is constituted by power, Carlos, including his spectral ideal ego, is the remainder from the outer crypt's resignification of the inner. The translation of the past, the production of new layers of narrativization carried out by historicizing powers - leaves a trace of what was translated. This is what Derrida refers to as a 'system of partitions' or the 'cryptic safe [that] protects from the outside the very secret of its clandestine inclusion or internal exclusion' ('Foreword' xiv). As Derrida explains, of course, the 'crypt is the vault of a desire' ('Foreword' xvii), clandestinely including and/or internally excluding a moment to which a desire is temporally bound. Carlos, as a colonial subject, is the novel's embodiment of that moment - the 'tropological inauguration of the subject' (Butler, Psychic Life 3). Power's desire for reproduction - the Lacanian desire of the big Other produces a string of moments in which the implied question of that desire (che vuoi?) is being answered. The interpellation of the subject, carried out by another subject's answering of Empire's desire, is a moment in which desire is inscribed. Carlos is ultimately unable to dissociate himself from that moment. The same can be said of the other narrators and specters that intervene in the novel's interior monologues-turned-dialogues.

\section{Conclusion}

Carlos's presence vis-à-vis the imperial outer crypt, both in the novel (as the national anthem) and in the postcolonial metropolitan public sphere, disrupts the translation of the inner crypt. Part of contemporary imperial 'linking' - to use Mignolo's term - is imperial power's present relationship 
between outer and inner crypts - essentially how they connect by strategically including or excluding. An example of imperial linking is thus the historicizing gesture of 'crypting. 'To crypt,' in the words of Derrida, 'is to cipher, a symbolic or semiotic operation that consists of manipulating a secret code' ('Foreword' xxxvi). In using the national anthem as the novel's epigraph, Lobo Antunes is likely steering the novel toward a particular national audience, entrenched in a particular signifying field. The novel, situated in the temporal and spatial location of the postcolonial metropolis, is thus read in relation to a particular moment of Empire's desire. The reading subject, inscribing meaning while reading, is also faced with the task of answering Empire's desire by participating in the imperial linking of outer crypt with inner crypt. Faced by this, Lobo Antunes opens a subjective conundrum by opening the spectral vault on the reader, forcing the reader to confront an internally excluded crypt and the voices that inhabit it. The novel's delinking thus aims to thwart the reader's job of following the imperial linkages that semiotically circuit the metropolis's exceptionalist cryptonomy.

Carlos, Isabela Figueiredo's father, and the other specters residing in the inner crypt of Portugal's colonial past - and Empire in general - represent a crucial decolonial step in the vein of Rancière's aesthetic regime. Patrícia Vieira's conceptualization of 'the archive-as-specter as a possible path to envisage the future' ('Specters' 343) in Os Cus de Judas thus also holds true for $O$ Esplendor de Portugal. Following Derrida, Vieira asserts that the 'future is hauntological; it arrives in and through ghosts. The archive-as-specter [...] will keep recurring in what is to come' ('Specters' 343). We can thus think of Antunes's form of spectrality as phantoms: texts (subjectivized beings) whose inscriptions within the inner crypt will continue to write against the outer crypt. It is this haunting that can in turn lead to a future narrative of the past. 


\section{Decolonizing Hybridity through Intersectionality and Diaspora in the Poetry of Olinda Beja}

$\mathrm{T}$ he works explored thus far in this volume have, in different ways and through different approaches, grappled with Empire's signification of time, space, and bodies, confronting imperial taxonomies of human life while offering interrogations of the performance of subjectivity in relation to power. Following up on these examinations, the remaining two chapters map proposals for alternative, non-imperial conceptualizations of global time and space. These tentative forms of narrativization do not operate in terms of a utopian new beginning in a world untouched by Empire. Instead, they trace the emergence of alternative epistemologies over and against Empire's field of meaning, particularly its categorizations of bodies and lands.

This has very much been the case with the $\propto u v r e$ of Olinda Beja, which evokes, appropriates, and reworks Empire's signifiers in order to remap the signified terrain of power while bringing about anti-imperial forms of local and global consciousness. For Beja, this project is closely tied to her own personal trajectory. An acclaimed poet, she is also the author of two novels and three collections of short stories, and is regarded as one the leading literary voices of São Tomé and Príncipe, the West African archipelago along the equator. Born in the São Toméan town of Guadalupe in 1946, she was raised under Portuguese colonial rule. She has lived most of her life, however, outside of São Tomé and Príncipe after a childhood move to Portugal followed by prolonged residence there and in Switzerland. This has undoubtedly contributed to her work both in terms of experiences to place on the page and a unique lens through which to perceive the world, beyond São Tomé and Príncipe and the former imperial metropolis.

Her first collection of poetry, Bô Tendê? ['Do You Understand?'] (1992), offers numerous poems reflecting on the consequences of moving to Europe as a young African girl, and learning about herself and the world through imperial pedagogy. Within this particular collection, the poem 'Visão' 
['Vision'] provides a visceral example of this, beginning with the very first lines:

Quiseram fazer de mim uma europeia

e por esse motivo me arrancaram

das costas de mãe-África, minha mãe. $(14)^{1}$

[They wanted to make me European

and for that reason they pulled me

from the back of Mother Africa, my mother.]

Although the poetic voice never mentions specifically to whom the third person plural pronouns refer, she nonetheless underscores the subjection to interpellation, which stems from a particular desire: 'they wanted to make me European.' Becoming European, or Europeanizing her, as she goes on to reveal, implies the adoption of the Western site of knowledge and narrativization as her own, viewing the world imperially, or better yet, learning to learn imperially:

Repuxaram meus cabelos, alisando-os

dando-lhes nova forma, esquecendo como

Medeia penteou os filhos de África.

Deram-me um colégio por escola

para aprender, enfim, boas maneiras e assim

poder entrar na sociedade. (14)

[They pulled back my hair, straightening it

giving it a new form, forgetting how

Medea combed the children of Africa.

They gave me a college for school

to learn, then, proper manners and thus

enter society.]

The altering of her hair speaks to a praxis of corporal transformation according to both European standards of beauty and, underneath that, European standards of valid personhood articulated here as the appearance of 'civilization.' Such a change of appearance always goes hand in hand with European and imperially disseminated notions of social respectability, thus tying it together with the socializing goal of acquiring 'good manners' in

1 All collections of poetry cited in this chapter can be found in the same anthology titled Aromas de Cajamanga e outras obras [Aromas de Cajamanga and Other Works]. 
order to 'enter society.' This Europeanization does not, to be sure, suggest a racial transformation into whiteness, but a European re-textualizing of the black body. This is a learning to reinscribe the body and perform identity - at the intersection of race, gender, class, and sexuality - according to European knowledge of bodies (including the beauty thereof), time, and space, as the next lines of the poem illustrate below. As the above excerpt also suggests, the imposition of European ways of viewing and inscribing the othered body - part of the field of meaning through which the other is interpellated - also implies the displacement and erasure of non-European modes of knowing.

In this regard, Beja refers to Medea, the eponymous character of Euripides' Greek tragedy, in which the discursive binary of 'civilized' versus 'barbarian' - an early example of orientalism and discourse of ethnic/racial difference - frames the action. As the plot of the play goes, Medea is a princess of the 'barbarian' (non-Greek) kingdom of Colchis, and is married to Jason. The latter divorces her in order to marry Glauce, princess of Corinth, a beacon of Greek civilization. In response, Medea murders the children she had with Jason in addition to his new wife. As Albert Wertheim's postcolonial reading of Medea explains, 'As a woman and an ethnic Other, Medea is the victim of a double patriarchy or double colonialism' (337). A similar experience is evoked throughout Beja's work, and the reference to Medea represents the celebration of an act against power. This is precisely what Wertheim extracts from the play:

The unexpected triumph of Medea despite her bloody deeds is the triumph not merely of a woman wronged but of female intelligence and, even more significantly, of the ethnic Other, who is always seen by the hegemonic culture as inherently less intelligent, less rational, barbarous, and literally or more often metaphorically female - and hence as an easy target for subjugation and exploitation by a masterful, intelligent, civilized, male 'superior' society. (377)

Here Beja deploys the figure of Medea in yet another related fashion - as a maternal entity that practiced motherhood through political engagement against Empire, that far exceeds any trite valorization of womanhood through motherhood. The act of filicide is an act of revenge but also bars the children from being placed into new modes of behavior and manners - like those experienced by Beja's poetic I. Medea is thus evoked as a subversive component of an anti-imperial mythology that resisted the incorporation of her children into Empire's realm of intersubjective meaning. Medea is, therefore, cited in the poem as a mother acting as a site of knowledge against Empire. Medea's combing of her children's hair, mentioned by Beja, speaks 
to the decolonial epistemology which Medea bestows upon her offspring, a knowledge of their bodies and larger existence not subsumed by the forces of Empire. By denouncing the 'forgetting of how Medea combed,' Beja's poetic voice underscores the erasure of non-imperial forms of knowing an erasure she experienced through her own interpellation into Empire as other.

The experience of interpellation outlined in 'Visão' offers important insights regarding imperial subjectivation into otherness. The poem's focus on Europeanization points to a process that begins with the cultivation of an imperial ideal ego of black femininity: the discursive formation of the sign which Beja is supposed to take on within Empire's signifying field. This is the sign/body that is to be performed, prepared for, and consumed by the white heteronormative male gaze that guides imperial signification. From this hegemonic scene of writing and reading social bodies, the ideal ego of black femininity is thus the crystallization and intersection of various forms of signified otherness, namely those pertaining to gender and race - the double colonialism mentioned by Wertheim above. These figurations of otherness come from those who have been imperially inscribed over the 'absolute otherness' (Cixous and Clément 70-71) of non-European bodies through the monologism of imperial historicization and subsequent foreclosure of non-European voices from the global signifying process.

The brand of otherness into which the poetic subject is being interpellated is, more specifically, an assimilationist one - an image of otherness placed on the black bodies that are most in quotidian physical proximity with white bodies. This would pertain especially to the imperial post-slavery metropolis where the poetic subject finds herself, and to different ranks of colonial administration or business where employment for colonized natives was often contingent upon assimilation. The specular image that corresponds to the assimilated other is thus an imperial negotiation between the signified abjection of non-assimilated subjects and a consumable form of exoticness - a sign in flux across different imperial fantasies of otherness. Entering spaces of white presence and control thus entails an assumption of this particular sort of specular image of identitarian totality. As such, this assumption is always regulated through the surveying function of a society whose intersubjective relations are imperially negotiated.

The performance of this imago in the subjectivation of the assimilated other entails a reading of the body through the imperial forms of knowledge that formulated it - the imperial knowledge pertaining to bodies, both European and non-European. Beja's poem thus brings to the forefront the pedagogical aspect of imperial subjectivation. It is not only the ideal ego/imago that is formulated by and embedded in Empire, but also the 
regulation of the relationship between the emerging subject and the imago. This regulatory function is itself widely disseminated at the quotidian level, particularly through the role of institutions. In this regard, Beja's poem underscores the experience of metropolitan schooling. Placement into Empire occurs, in other words, through Empire's epistemology - a realm of knowledge that also stipulates how to know. The imperial signifying field is simultaneously text, reading, and reinscription. This is also the tripartite existence of the subject. Beja is thus taught how to read and understand the imperially formulated world in order to reproduce its field of meaning through her performance of imperially inscribed otherness:

Obrigaram-me a cantar todos os rios

montes, montanhas e até

ganhei um belo prêmio por saber tudo

sobre o mar e sobre a terra

$[\ldots]$

Fizeram-me decorar todos os reis

seus nomes, cognomes, dinastias

mas esqueceram que na terra do cacau houve

um Amador

que foi mais bravo que o mais bravo dos reis de

Portugal. (14)

[They forced me to chant all rivers

hills, mountains and I even won

a nice prize for knowing everything

about the sea and the earth

(...)

They made me memorize all the kings

their names, nicknames, dynasties

but they forgot that in the land of cocoa there was

an Amador

who was braver than the bravest of the kings of

Portugal.]

For Beja, every piece of imperial knowledge implies the erasure of a piece of non-imperial knowledge or act of knowing. The last four lines above pertain to a piece of anti-imperial knowledge, much like the example of Medea. The Amador evoked is revered in postcolonial São Tomé and Príncipe as an anti-imperial figure who led a slave revolt against Portuguese colonial authorities in 1595 . The erasure, or 'forgetting,' mentioned in the poem 
speaks also to the function of imperial historicization of events - what is inscribed and what is omitted from the Western narrative of History, and for what purposes. In this case, the purposes are inevitably multifaceted. This erasure of an anti-imperial act maintains intact Empire's representation of itself, and its European masculine core, as an impenetrable and superior entity while at the same time maintaining imperial fantasies of colonized subjects as inferior, needing of European presence, docile, or, on the flipside, ungovernable. The comparison here refers to a particular positive quality that of bravery - which becomes an integral part of the discursive makeup of Western mastery (such as the European kings mentioned in the poem) while it is negated from the imperial articulation of otherness.

Like the imperial articulation of global terrains (rivers, mountains, and seas), the imperial articulation of blackness - as other - is thus the only one rendered accessible to the poetic subject. It is subsequently through this particular image of blackness that the subjectivized other comes to know herself. This encapsulates the fundamental predicament to which W. E. B. Du Bois refers with the term 'double consciousness': 'this sense of always looking at one's self through the eyes of others, of measuring one's soul by the tape of a world that looks on in amused contempt and pity' (3). The subjectivation into narrativized otherness within Empire implies an identity that has been constructed and is then observed and regulated from without. Du Bois's theorization of the 'American Negro' notably begins with this split, which leads to others: 'One ever feels his twoness, - an American, a Negro; two souls, two thoughts, two unreconciled strivings; two warring ideals in one dark body, whose dogged strength alone keeps it from being torn asunder' (3).

The Du Boisian theorization of racialized subjectivity - experiencing the realm of social meaning as other - points to a hyper-awareness of the regulatory function of this symbolic realm, which is itself composed of interpellated subjects. As Fanon would further elaborate half-century later in Black Skin, White Masks, the gaze that regulates, disseminated among other interpellated subjects within Empire's signifying field, is intimately tied to the imperial production of the othered body. Not only is the body regulated; it is a signifier palimpsestically formulated through the reproduction of imperial meaning, the reproduced fantasies of otherness over which fantasies of white/bourgeois/male/heteronormative superiority could be performed and inscribed. The regulatory function would thus serve to ensure that the body continues to fit the signifier of otherness into which it is interpellated.

The fundamental crux of double-consciousness can thus be unpacked via Fanon's interrogations of 'the lived experience of the black man' (Black Skin 89) as one framed by imperial narrativization and knowledge, as 
Beja's poem also points out. Fanon notably speaks of the image of the body schema - 'an image in the third person' (90). In regard to how his interpellated body comes to move and perform, in the everyday sense, through the realm of intersubjective meaning, he pinpoints the ordeal of the subjectivized other:

I make all these moves, not out of habit, but by implicit knowledge. A slow construction of my self as a body in a spatial and temporal world - such seems to be the schema. It is not imposed on me; it is rather a definitive structuring of my self and the world - definitive because it creates a genuine dialectic between my body and the world. (Black Skin 91)

Du Bois's 'looking at one's self through the eyes of others' implies, for Fanon and Beja, a living as a body/text whose movements and actions are inscribed a priori and are therefore part of a realm of meaning constituted as the product of Empire's desire for reproduction. Fanon's visceral awareness of the psychic experience of race is also an awareness that his body moves, thus producing meaning, in accordance with how it was taught to move by Empire's pedagogy of subjectivity. It is this conclusion that he summarizes succinctly: 'not only must the black man be black; he must be black in relation to the white man' (Black Skin 90).

Beja's body in her poem is thus guaranteed a place within Empire - as other - by following the identitarian roadmap that is implied by interpellation into the ideal ego. The voice behind the poem operates, therefore, through a fundamental cognizance that the body portrayed is one that has been narrated a priori. As such, the poem details how the body in question was placed into that particular text, as well as some of the significational mechanisms behind the formulation of the body/text. The following stanza of 'Visăo' conveys more of the actions laid out for her body/text:

Tentaram fazer de mim uma europeia

e aconselharam até que quando um dia

chegasse a hora certa do amor

escolhesse alguém em cuja cor

se notasse bem a nobre raça

para que assim ficasse assegurado

aos descendentes da minha geraçáo

o esquecimento total da negritude

que resultou de uma loucura do meu pai ...

'tudo por bem eles disseram

tudo por bem eles fizeram!' (Bô Tendê 14) 
[They tried to make me European

and advised me that when the time

came to fall in love

I should choose someone in whose color

one can clearly see the noble race

so that it would be guaranteed

to the descendants of my generation

the complete amnesia of blackness

that originated from my father's folly ...

'all for the best they said

all for the best they did!']

Part of the text - Beja's story written for her - formulating her specular image of subjective totality implies, of course, particular sexual mandates that will enable her to reproduce the symbolic realm in which she is placed. The larger mandate ascribed to her, in order to reside in the metropolis, is the erasure of negritude mentioned throughout the poem, for the sake of the European-sanctioned and ventriloquized formulation and performance of black identity. Negritude, as evoked by Beja, means not only blackness, but formulations of blackness and knowledge that contest or reside outside of Empire, those that have also been foreclosed by Empire. As a subject, Beja's interpellation implies the synchronization of her desire with that of Empire by circuiting it toward the signifiers of white 'superiority,' formulating sexual and romantic desire as desire toward whiteness - the object of desire (sexual, racial, and social) for metropolitan life.

This portion of the poem points toward a transition in the imperial formulation of black subjectivity within the metropolis. The imperially inscribed specular image of blackness into which Beja and Fanon are interpellated must lead to a trans-generational erasure of blackness. This trans-generational signifying chain of the metropolis must lead, from one signifier to another, to the realization of the fantasy of a white Europe. Beja's poem reveals interracial sex to be a dialectical mode of achieving this imperial absolute of Europe - the inscribed universality/whiteness of Europeanness which has never fully existed. It is in this sense that Beja's poem mentions the 'folly' of her father - a European man who compromised this particular mission toward the absolute.

To be clear, the imperial goal of a white Europe operating within the poem never means an eradication of alterity, for the fantasy of whiteness operates in tandem with the palimpsestic and floating fantasies of otherness. Europe, though, as the geo-cultural and political core and phantasmatic origin of universality - what Audre Lorde has referred to as 'the mythical norm' (116) 
- must be inscribed as the embodiment of such a core, the embodiment of the ideals of a global sphere of intersubjective existence purportedly molded by European civilization. In being mandated to act toward and desire this goal, Beja reminds us of Saidiya Hartman's argument on the subjectivation of the slave: 'the slave is made to speak the master's truth and augment his power' (22).

\section{The Intersectionality of Subjectivation}

The grappling with Empire in this poem, particularly its subjectivation and circuiting of the desire of the othered body, in many ways lays the groundwork for Beja's larger auvre. It conveys the backdrop of imperial power and discourse against which her poetry, and especially her poetic site of articulation, emerges. More than touching upon different aspects of Empire and its modes of reproduction - imperial knowledge, foreclosure of non-Western forms of knowing, fantasies of sameness and otherness, formulation of sexual desire - 'Visão' provides a glimpse into the converging imperial categories that constitute the racialized and gendered subject residing within what Patricia Hill Collins has termed the 'matrix of domination' (18).

Kimberlé Williams Crenshaw has crucially named this intermingling of corporal categories that inform power and privilege 'intersectionality.' While her seminal essay 'Demarginalizing the Intersection of Race and Sex: A Black Feminist Critique of Antidiscrimination Doctrine, Feminist Theory and Antiracist Politics' (1989) focuses particularly on the confluences of race and gender and the challenges facing black feminism, the term has a notably broadened scope. Through the work of both Crenshaw and other theorists, namely within critical race theory, intersectionality has become a key framework through which to examine quotidian and institutional experiences of individuals across myriad categories such as ethnicity, disability, sexuality, class, education, age, and residence in addition to race and gender. From a legal perspective, Crenshaw's work lays bare the institutional blindness regarding, and lack of protection for, individuals whose social experiences are informed by intersecting identity classifications. Citing a plethora of court cases implicating discrimination against black women in the United States in the realms of work and education, Crenshaw underscores the discrepancy between how privilege and disenfranchisement operate and are experienced intersectionally. Her interrogations of the legal system, particularly cases affecting black women, reveal how anti-discrimination laws operate under single-classification systems. In other words, discrimination, as both a symptom and a practice 
of power, privilege, and disenfranchisement, is only judicially legible in terms of 'race discrimination, sex discrimination, or alternatively either, but not a combination of both' (Crenshaw 141).

Crenshaw's work on intersectionally urges us to destabilize one particular category as the essence of social experience and thus approach the subject's existence within the spectrum of power and intersubjective meaning by the way in which the different imperial classifications of bodies mentioned above interact in signifying one another. Beja's 'Visão' offers an interesting case study in intersectionality by narrating the subject's interpellation through such intersecting categories. The signifiers making up these categories are inscribed at the level of the specular image into which she is interpellated. The formation of this imago does not emerge spontaneously, however. It is, of course, the product of centuries of imperial historicization and imperial taxonomies of bodies. As an inscribed sign for the reproduction of Empire, the specular image emerges in response to the exigencies of the moment in which it is engendered. In this regard, the intersections of race, gender, and sexuality for her specular image are inevitably shaped by residing in the metropolis - a signified imperial space itself shaped by its claims to whiteness. The specular image at work in the poem also follows what is understood to be her European father's 'folly' in having a child with an African woman. Her existence, pre-interpellation, is thus regarded as compromising the metropolis's Manichaean ideals of whiteness.

The intersecting of categories at the level of the specular image is thus negotiated by the forces that inscribe, reproduce, and regulate imperial ideals. Imperial desire, that which must be reproduced, does not exist as a single embodiment. Rather, the ways in which meaning is inscribed at the service of imperial power varies by location and how that location is embedded within Empire. Beja's poem deals specifically with the metropolis. In order to preserve the phantasmatic whiteness of the metropolis, and thus set her identity on a course toward retrieving that whiteness, her intersectional subjectivity is guided beginning with interpellation. Through her placement into the imago, this metropolitan desire for whiteness must become her own - as the famous Lacanian dictum tells us, 'desire is the desire of the Other' (Écrits 582). In becoming part of this economy of desire, she is taught how to think of her skin color through imperial discourses on racial otherness and sexual desire for white European men.

In circuiting her desire as a black woman with that of the imperial reproduction of metropolitan whiteness/Europeanness, she is to become the object of white heterosexual male desire. Her performance of the specular image must appeal to a metropolitan male gaze that is also interpellated into the desire for metropolitan whiteness. Her performance of womanhood, in 
other words, always carries racial implications, for it must be a particular version of black womanhood in order to be desired; a version calibrated through imperial masculine heterosexual fantasies of African women and notions of whitening this same othered body. The intersectional inscription of the black female body by the significational forces of Empire highlight another element of the politics behind the imperial contexts of interracial sex celebrated in Lusotropicalist discourses. This would be the underpinnings of white supremacy and the trans-generational erasure of blackness at the heart of the championing of miscegenation.

The intersectional formation of the operative specular image in the poem lays the blueprint for the subject's performance of identity as the response to Empire's desire, namely that of metropolitan whiteness. In considering intersectionality as the confluence and interplay of signifiers of race, class, gender, sexuality, age, ability, and health, we must also examine how this interplay is guided and negotiated by the demands of the particular narrative in which the intersectional sign is couched. It is within the phantasmatic narrative of metropolitan whiteness that Beja and her poetic subject experience this particular interplay. We can thus think of this form of subjectivation as its own experience of hybridity.

A widely contested and oft-cited theoretical term within the study of colonial discourse and imperial power, both during and after formal colonialism, 'hybridity' has become an object of study and part of a critical lexicon. ${ }^{2}$ Homi K. Bhabha notably brought the term to the forefront of colonial discourse studies as a way of problematizing claims to cultural origins and authenticity - as a 'partializing process' (163) that calls for 'the revaluation of the assumption of colonial identity through the repetition of discriminatory identity effects [... and] displays the necessary deformation and displacement of all sites of discrimination and domination' (159). Bhabha reinaugurated the term from its colonialist origins of racial mixing as a way to think through identities, both individual and collective, as formulated through colonial discourses of race and ethnicity. In this sense, the term stands for a contestation of discursive binaries and phantasmatically fixed notions of sameness and otherness.

Since Bhabha's introduction of the term in his essay 'Signs Taken for Wonders' (1985), numerous theorists have offered important dialogues and responses to the term's implications and historical weight. Robert J. C. Young's Colonial Desire: Hybridity in Culture and Race (1995) provides a book-length exploration of the term, offering a critical genealogy of its

2 Hybridity, in the context of Latin American cultural production, is also explored in Chapter 2. 
use within colonial discourse and as a theoretical tool against it. Avtar Brah and Annie Coombes published Hybridity and its Discontents: Politics, Science, Culture (2000), a collection of essays dedicated to the topic with contributions from scholars including Donna Haraway, Jo Labanyi, John Kraniauskas, and Ann Laura Stoler. In Writing Diaspora, Rey Chow gets to the crux of the critical contestation toward Bhabha's deployment of the term:

What Bhabha's word 'hybridity' revives, in the masquerade of deconstruction, anti-imperialism, and 'difficult' theory, is an old functionalist notion of what a dominant culture permits in the interest of its own equilibrium. Such functionalism informs the investigatory methods of classical anthropology and sociology as much as it does the colonial policies of the British Empire. (35)

Bhabha's development of the term is not, however, limited to emancipatory possibilities. In his elaboration of the ideological mechanisms behind hybridity, namely the Derridean concept of différance as the postponement of meaning (explored in Chapter 3), Bhabha does not fail to note how such a postponement is also central to the 'productivity of power' (165). Hybridity's tones of functionalism, underscored by Chow, point to the fact that hybridity does not displace imperial power's right to signify, itself reproduced through its own modes of hybridity and performance namely in the discursive (re)formations of otherness. Stuart Hall arguably best theorized this modus operandi of Western imperial power in his famous lecture 'Race, the Floating Signifier,' which approaches the sign of racial otherness as a palimpsest, constantly rewritten in order to fit the demands of imperial power.

In discussing the possibilities of decolonial resistance, I wish to avoid a utopian or even naïve understanding of the political impact of postcolonial literatures that contest current configurations of global power and imperial categories of human life. Such literary products reside, as we know, at the margins of cultural circulation, and this circulation itself depends largely on metropolitan readership and how such products are placed within metropolitan and Western narratives. Therefore, as much as a literary work may problematize imperial knowledge, in deploying Bhabhan notions of hybridity and instability, its global political impact is limited to some extent due to the continuity of imperial control over canonization and dissemination. A work derived from a colonial past and/or the intersecting modes of imperial power can, nonetheless, offer new and decolonial modes of global and intercultural understanding. 
In this regard, Beja's poetry gestures toward an imagining of global space against imperial signification through her own intersectional experience of power, time, and space outlined in 'Visão.' While Bhabha's use of hybridity contests the dichotomous foundations of imperial thought - self/other, inside/outside, civilized/savage - by theorizing the presence of one inside the other, intersectionality may offer a reformulation of hybridity as the intermingling of different signifiers of otherness in the subjectivation of the othered body. Like Bhabha's conceptualization, this sort of hybridity also implies a constant postponement of meaning in how the subject is placed within the imperial intersubjective signifying field. Racial signifiers, for instance, postpone and rewrite signifiers of gender and class. In the portrayal of interpellation in her poem, Beja traces the relationship between racial signifiers of otherness, most notably those concerning hair, as manipulated and rendered toward a particular circuiting of sexual desire - for the sake of metropolitan desire; that is, the reproduction of whiteness and concomitant elision of blackness.

The intersection of imperial categories of corporal and subjective signification that marks social experience is one of floating signification, to borrow Stuart Hall's metaphor mentioned above. What Crenshaw's work on intersectionality teaches us is that imperial otherness, such as that into which Beja is interpellated, is never rendered by a single imperial category. Bhabha's formulation of hybridity effectively points to the instability that characterizes imperial categories and figurations of phantasmatic otherness, floating from one figuration to another; hence his seemingly contradictory statement regarding the 'productivity of colonial power' as a series of 'shifting forces and fixities' (159). The temporary fixity of otherness, such as the moment of interpellation in which the individual is placed into the specular image/ signifier of identitarian totality, is predicated on the interplay and mutual postponement of signifiers of otherness. After all, the subject in Beja's poem is not interpellated as simply black. The social experience she is to have in life - for Empire, in accord with Empire's desire - is predicated on more than racial signifiers. In order to partake in the reproduction of the imperial symbolic toward its phantasmatic goals, she must experience it as a black heterosexual woman born in Africa, transplanted to the colonial metropolis, desiring of sexual relationships with European men, and desiring of a trans-generational return to filial whiteness.

In this sense, the intermingling of imperial categories of otherness at the intersection is contingent upon and guided by imperial desire and the demands of the particular imperial symbolic realm into which the subject is placed. 'Visão' concludes, however, with a response to this placement and the gradual erasure of blackness in which she is made to participate: 
Conseguiram fazer de mim uma europeia

só que se esqueceram de cortar

o cordão umbilical que ficou preso

nas raízes da velha eritrineira

que meu bisavô plantou em Molembu. (Bô Tendê 15)

[They were able to make me European

only they forgot to cut

the umbilical cord that remained tied

to the roots of the old eritrineira ${ }^{3}$

that my great-grandfather planted in Molembu.]

Part of Beja's rejection of the trans-generational trajectory of black erasure implies her own resignification of a trans-generational past. In opposition to the realm of knowledge into which she is placed through metropolitan schooling, the final stanza offers a revised, decolonial map of time and space, which Beja further develops later in her work.

This final stanza can be read as a blend of resignation and triumph, the former in terms of her interpellation into a particular version of Europeanness, or at least as an other for the European phantasmatic self. Meanwhile, triumph is suggested in the resistance to metropolitan imperial desire - a political stance against the erasure of blackness by laying claim to a version of locality, identity, and culture that has not been signified by imperial power. In this sense, Beja's poem gestures toward a formulation of non-imperial knowledge that had been foreclosed from the moment of imperial interpellation, by evoking a particular spatially and temporally localized act committed by her great-grandfather. The planting of the tree itself can be understood as an inscription on space, an act of knowing not based on larger forces of power. As such, Beja calls upon not only a sign of identity but also a form of knowing that fundamentally diverges from the version of imperial otherness which she confronts through interpellation. In addition to sidestepping imperial notions of non-Europeanness, Beja also avoids falling into essentialist conceptualizations of identity, evoking an unfixed site of knowledge that is itself always in negotiation vis-à-vis the impact of imperial power on the world.

3 Eritrineira is a species of tree that is a ubiquitous presence in São Tomé e Príncipe's biodiversity. 


\section{Double-Consciousness from the Intersection}

'Visão,' one of Beja's early poems, sets the political tone for her later work, particularly in its evocation of competing sites of knowing - pertaining especially to the imperial narrativization of Europe, and therefore, the bodies that circulate within it. From there, the poetic voice in 'Visão' elaborates what we may refer to as an emergent decolonial gnosis. The poem itself develops around these two sites - the imperial and the decolonial - and their inherent tension. It is through the budding decolonial gnosis in the final stanza, however, that Beja reflects decolonially on the process of interpellation that occupies the bulk of the poem. It is only at the end, in other words, that we begin to grasp the poet's scene of writing as it dialogues against History.

At the core of this decolonial gnosis, from which emerges a particular mapping of time and space in Beja's later poetry, is a reclaiming of the significational dynamics of her poetic voice's intersectionality. Through this negotiation of the signifying process across imperial categories, Beja's work gestures toward the undoing of such categories by destabilizing their claims to truth. In this regard, Beja's poetry draws parallels in terms of cultural politics with those of Gloria Anzaldúa, particularly the latter's formulation of la mezcla, Anzaldúa's own version of critical hybridity. Anzaldúa's term points toward a constant resignification of categories - ethnicity, gender, class, and sexuality - in order to open contemporary power's spectrum of monolithic identities. Such a call to arms is based on each individual's renegotiation of these categories. Where Anzaldúa's la mezcla and Crenshaw's intersectionality differ theoretically from Bhabha's hybridity is in their approach to social and symbolic existence vis-à-vis imperial categories of human life and global time/space. Where Bhabha focuses on interstitiality, residing in the critical space between categories, Anzaldúa and Crenshaw focus on the overlapping of categories from which, for Anzaldúa especially, new identitarian spaces can emerge and displace those that have been established, fixed, and shifted by the spectrum of imperial power.

It is precisely this open-endedness regarding postcolonial identity that can be found in Beja's aptly titled poem 'Identidade' ['Identity'] from her collection No País do Tchiloli ['In the Country of Tchiloli'] (1996). 'Identidade,' moreover, contains an additional important and related strand of Beja's work - her relationship with São Tomé and Príncipe, whence she emigrated at a young age and returned later in life. The title of the collection is particularly relevant to Beja's larger political project. The term tchiloli refers to both a São Toméan piece of theater and a particular approach to theater and performance originating in colonial São Tomé and Príncipe as a form of cultural resistance to Portuguese authority. Tchiloli was the São Toméan 
Creole name given to the production by a local theater company of Tragédia do Marquês de Mântua e do Imperador Carlos Magno ['The Tragedy of the Marquis of Mântua and the Emperor Charlemagne'], originally written in the sixteenth century by the Madeiran poet Baltazar Dias. The legacy of the original tchiloli continues today with the annual performance of Auto de Floripes [Act of Floripes] on the streets of Príncipe Island by its entire population. Considered a tchiloli, Auto de Floripes itself embodies the cultural politics of the original tchiloli, staging a medieval battle between Christians and Moors through São Toméan language and cultural signifiers in addition to improvised props and diegetic space.

In this regard, tchiloli has come to stand for a mode of cultural production based on the appropriation and resignification of previous cultural products from both Europe and Africa. Such a performance, moreover, represents a signification of European history by the postcolony. The tchiloli thus implies an act of knowing. Regarding São Toméan history and its cultural formation prior to and following colonization, Inocência Mata posits the nation as the result of various cultural encounters between identities and cultural expressions that were also products of dynamic political and cultural forces: 'São Tomé e Príncipe, mestiça nação africana que concilia elementos de culturas já então mestiças quando da sua integração, é o resultado de um doloroso processo transculturativo que prolongou por muitos séculos' ['Săo Tomé and Príncipe, a mixed-race African nation that reconciles elements of different cultures that were themselves mixed-race when integrated, is the result of a painful transcultural process that lasted many centuries'] (18). As Mata indicates, thus avoiding a blind celebration of colonial cultural dynamics, São Toméan cultural expressions such as tchiloli are born of violence and resistance. It is the dialectic of struggle - political and cultural - that has engendered what is for Mata a postcolonial Atlantic, a 'redistribuição do mundo atlântico, de nova configuração do mundo através dos Oceanos' ['redistribution of the Atlantic world, a new configuration of the world by way of the Oceans'] (18). Within the remapping of the world through European expansion, Mata underscores the ways in which local cultural practices of São Tomé and Príncipe, as part of the postcolonial Atlantic, have implied non-imperial forms of knowing, rethinking, and historicizing such a mapping.

In this sense, Beja's work follows a particular São Toméan poetic tradition of simultaneously rethinking the nation, its imperial past, and its current imperial realities in the postcolonial moment. Clariane Crippa and José Pires Laranjeira point out the ways in which the poetry of Beja's fellow São Toméan poet Alda Espírito Santo intertwines national redefinition and larger intersectional struggles of power: 'mais do que instituir uma literatura santomense, corroboraria a criação de uma luta pró-feminina de 
cariz político-ideológico muito próximo das ideias do marxismo' ['more than instituting a São Toméan literature, (Espírito Santo) would corroborate the creation of a pro-feminist struggle of a political-ideological brand very similar to Marxist ideas'] (5-6). Like Espírito Santo, Beja's sort of decolonial nationalism carries implications far beyond the scope of nation, and addresses modes of power that exceed the political and historical framework of Portuguese colonial power by targeting global exercises of power expressed intersectionally.

Most importantly for Beja's political stance, tchiloli implies a particular decolonial scene of writing, one of constant reinvention from which global events are inscribed outside of, or in opposition to, imperial modes of historicization. The very title of Beja's collection - No País do Tchiloli - thus sets the political tone for many of her later poems, both in tracing an ethics of signification for emergent scenes of writing - such as that of the poet herself - and in carrying out a decolonial production of meaning that challenges and effaces the imperial categories confronted in Beja's earlier 'Visão.' We can, therefore, observe a shift in cultural objective from one collection to the next, from a grappling with Empire and Beja's placement in it, to a searching for decolonial modes of signification.

Like her notion of selfhood, São Tomé and Príncipe emerges, especially in 'Identidade,' as a sign in flux following formal colonialism and in its postcolonial relationship with Empire. In this regard, Beja's poetic articulations regarding the postcolony carry a profound affinity with her own quotidian plight with colonial discourse, both having been signified by imperial entities and placed within imperial desire. As such, both appear in a state of postcolonial renegotiation:

Por vezes procuro-me

por toda a ilha [...]

farrapos de mim voam em círculos fatais

no chão dos milhos e das mandiocas

possuindo os ramos entreabertos

das plantas rastejantes. (125)

[At times I search for myself

throughout the entire island (...)

tatters of me fly in fatal circles

on the ground of corn and yucca

possessing the open branches

of the crawling plants.] 
From the very beginning of the poem, Beja's own identity and the postcolony/ sign are configured as overlapping terrains of unfixity and openness, a permanently incomplete project underscored by the ellipsis at the end of the first stanza. Moreover, the two incomplete signs inform one another, for consistently renegotiating herself and her scene of writing is contingent upon her persistent resignification of São Toméan space. More importantly, this space in flux emerges as the ideal setting to grapple with, and overcome, the intersectional imperial signification of her body. It is no wonder, then, that the second stanza is driven by potent imagery of the fragmentation of her body undergone at the moment of interpellation into Empire. In negotiating the postcolony for herself, from the subject-position of an exile raised in the metropolis, Beja seeks transcendence of Empire's field of meaning, and of the 'tatters' left of her body and subjectivity.

This evocation of the interpellated other through an imagery of destruction and fragments caught in an infinite whirlwind of death - communicated by fatal circles arguably referring to the palimpsestic nature of imperial signification - offers yet another crucial insight into the conceptualization of power through intersectionality.

This particular stanza calls attention to Empire's operation of intersectionality as centered on fragmenting the body and its actions, including skin color, genitalia, and hair. The fragmenting schema of the imperial signification of otherness operates by inscribing racial, sexual, gender, and socioeconomic meaning onto the fragments as they become fetishized pieces of otherness. In acting as a fetish within the societal life of imperial power, each fragment is attributed its surplus value. Like Marx's reflection on the commodity, the othered fragment, or the fragment as signified kernel of otherness, 'is, in the first place, an object outside us, a thing that by its properties satisfy human wants of some sort or another' (Capital Vol. I 43).

Marx deploys his brand of dialectical materialism within this statement. The properties of the 'thing' to which Marx refers are signified through the dominant modes of production; hence his equivalence of the commodity with 'crystallized social labor' (Capital 202). As a result, for the sake of maintaining such modes of production and the capitalist balance of power, the 'human wants' to be satisfied through the commodity must be aligned with the fundamental desire of the big Other - its homeostatic balance. Therefore, the fetishized fragment of otherness, as a commodity to be consumed, also satisfies the desire of interpellated imperial subjects as circuited to the desire of Empire. The circularity noted in the poem also speaks to this imperial dialectic into which the othered body is placed. Beja thus establishes, furthermore, a parallel between the circulation of her body/sign within Empire and that of the former colony. 
It is, therefore, through the evocation of São Toméan space that Beja seeks to reclaim the fragments of her interpellated self, as well as the right to (re) signify them. The postcolony is not configured here as a sort of blank space for identitarian inscription. Rather, it seems to embody the postcolonial renegotiation sought by the poetic voice. In this regard, Beja's relationship to São Tomé and Príncipe, as a locale of return, is more than a simple search for a lost origin in hopes of establishing a sense of identitarian totality. The fatalistic imagery deployed to convey imperial fragmentation seems to imply a recognition that such an objective is unattainable. In this regard, the poem, particularly the final stanza, appears to frame Beja's search, not for a past lost at the moment of departure, but for a future to be inaugurated and reinaugurated:

eu quero continuar a procurar-me

na orla infinita das praias e das gentes. (126)

[I want to continue looking for myself

on the infinite shore of beaches and peoples.]

The allusion to an infinite margin, like the border as a site of negotiation between overlapping categories, emphasizes the permanent indeterminacy of postcolonial signification. Furthermore, the final line evokes this as an infinite interplay between an infinite number of shores (themselves margins) contained within the larger infinite margin at the beginning of the line. The endless number of shores and people reveals a space of collective articulation pertaining to time, space, and bodies. In this sense, the border or margin for Beja represents a metaphorical space constituted by subjectivities that are themselves borders - individuals located at the intersection of various epistemological categories and, thus, sites of signification in negotiation. Subsequently, the signification of space and self occurs through a dialogic negotiation with other subjectivities/sites of signification. This entails an open postponement without political grips over reality and monologic claims to truth.

This particular collection of poetry, No País do Tchiloli, can be thought of as enacting the infinite journey of postcolonial signification (of self, space, and community) and reflecting on the contours of one's scene of writing. In this sense, many of the poems that comprise the collection grapple directly with the fragmented nature of an earlier imperial specular image of herself - a collection of pieces signified together through Empire's desire. A potent example of this is centered on the gesture toward reconstituting the imperially signified body, in the poem 'Forma Corporal' ['Corporal Form']: 


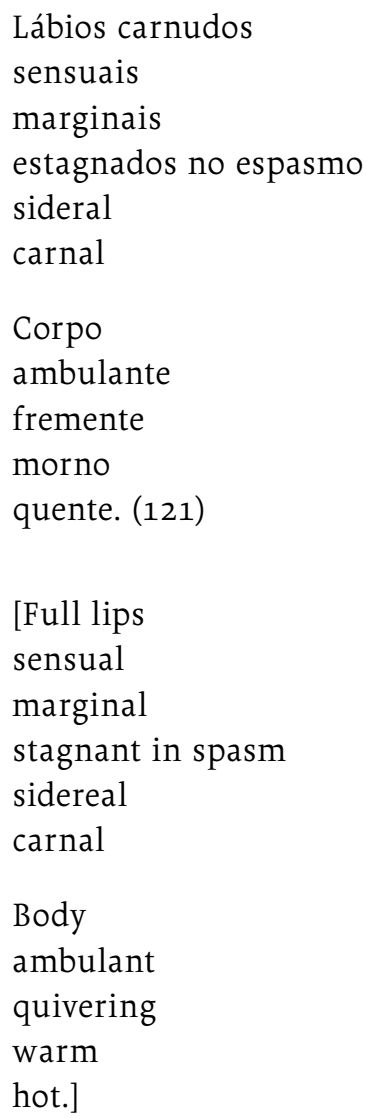

The poem presents a sequence of adjectives pertaining to particular conditions, focusing on two entities - the lips as fragment in the first stanza, and the body as a tentative whole in the second. Both entities are, moreover, described via differing adjectives evoking divergent sets of images.

The first stanza appears to speak to Empire's fragmentation of the body and imperial value ascribed to this 'tatter,' as the previously analyzed 'Identidade' would call it. Within the imperial process of othering, the 'sensual' and 'marginal' certainly overlap and mutually reproduce one another. The fragment, othered as sensual, always refers to an imperial grip on signification safeguarded by the marginalization of the other. This, of course, is a marginalization which signified otherness in turn helps to render. The stagnation alluded to in the proceeding line arguably carries a double meaning, referring to both the momentary fixity of the fragment within imperial schemas of otherness, as well as Beja's experience of such fixity, experiencing the signifier of otherness as an imprisoning edifice within which the body may only spasm. 
The constrained movement implied by the image of the spasm in stagnation appears to contrast with the images through which Beja evokes the body in the second stanza. We can thus argue that the shift from the first stanza to the next, from fragment to whole, represents a reclaiming of the body or, more specifically, a reclaiming of the earlier fragment (lips) in the body that is in a state of reclamation. The divide, or the space between the stanzas, thus evokes Beja's margin or border of transition against the imperial ordering of her body. What follows is an enunciation of the body after the fragmentation through images of movement, both large (ambulant or shifting) and small (quivering). While the fragment is articulated through stillness and momentary determinacy, the body, as Beja signifies it, is conveyed through images of unfixity and indefiniteness. As such, Beja renders the body and the modes of signifying it as a border entity in constant negotiation with the other borders/scenes of writing the body encounters.

The very signifying chain of the poem, moreover, is representative of this unfixity. The largely one-word lines comprising the two stanzas each bring forth a signifier in relation to others of the poem. The signified, however, is openly left to the act of reading due to the poem's lexical scarcity. As such, the poem's signifying chain is always incomplete, thus mirroring the act of decolonial signification proposed by Beja. In evoking just a few images, mainly through adjectives, Beja purposefully leaves the poem open to the reader's own system of linguistic differences while also permitting the reader - also a border with which Beja seeks to dialogue - freedom to postpone each word in relation to the others, thus allowing the formation of different signifying chains. In this sense, the dialogic tone of the poem suggests that any scene of reading is always a scene of writing, a postcolonial/decolonial hermeneutics in which interpretation itself becomes an unconstrained form of inscription through which different forms of knowledge can exist. Beja's deployment of decolonial dialogism thus challenges Empire's 'conception of knowledge based on the distinction between epistemology and hermeneutics' (Mignolo, Local Histories 13). Such a distinction, as Mignolo argues, has 'subalternized other kinds of knowledge' (Local Histories 13).

\section{Borders: Mapping a Decolonial Sign-System}

The development of the poem, as read here, is predicated on a consciousness of the intersection, a mode of thinking in terms of race and gender, not as separate entities but as overlapping parts of a social experience within the power-driven realm of meaning. This is similar to Du Boisian 
double-consciousness, an awareness of both as intersecting parts of the same tentative imperial whole that is the sign of the other. The space of the intersection, also a sort of border constructed by overlapping categories of humanity and personhood, always implies a thinking and performing through and/or against each category, not as its own freestanding entity but as a relational inscribing device of power. In this sense, Du Bois was, at the time of writing The Souls of Black Folk, already theorizing the effects of intersectionality. Frances Beale notably unpacks this intermingling of categories, particularly race and gender (and, to a lesser extent, class), by conceptualizing it as 'double-jeopardy' (Beale), not as 'two thoughts' (Du Bois 3) - as the yoking of multiple forces of power and social organization producing one form of thinking.

Olinda Beja's evocation of borders or margins serves to articulate the intersectionality of her experience within and against Empire, in addition to gesturing toward an uncontained quantity of scenes of writing. As such, Beja's poetry presents the various layers of power, privilege, and resistance that go into what Mignolo called 'border gnosis' - 'a powerful and emergent gnoseology, absorbing and displacing hegemonic forms of knowledge into the perspective of the subaltern' (Local Histories 12). Mignolo explains his use of "gnosis" as a term that would take us away from the confrontation - in Western epistemology, between epistemology and hermeneutics, between nomothetic and ideographic "sciences" - and open up the notion of "knowledge" beyond cultures of scholarship' (Local Histories 9). By 'cultures of scholarship,' Mignolo is speaking of course of those that have cemented their claims to global truth through and for Western imperial power. In recovering the terms 'gnosis' or gnoseology,' Mignolo attempts to announce a space for subaltern knowledges outside of an imperial lexicon. For Beja, subaltern knowledge and its implied scenes of writing grapple with the forms of power that have marginalized them and/or engendered them, as is the case with her own border politics of intersectionality.

In one of her most recent poetry collections, Aromas de Cajamanga ['Aromas of Ambarella'] (2009), one can find yet another step in Beja's poetic engagement against Empire. Shifting from the engendering of an unfixed, 'border,' scene of writing to a decolonial articulation of time and space, Aromas de Cajamanga contains crucial examples of Beja's border at 'significational' work. Like her earlier collections, the title, and indeed many poems within the collection, evoke significant imagery pertaining to the postcolony. As in No Pais do Tchiloli, the poems of Aromas de Cajamanga also labor toward a constant negotiation of São Tomé and Príncipe as a postcolonial nation/sign within global intercultural space. As such, Beja's enunciatory work regarding São Tomé and Príncipe is never isolated from 
a farther-reaching project of thinking global spaces against the grain of an imperial episteme.

This is particularly underscored in yet another aptly titled poem, 'Terra' ['Earth'], where we encounter a reflection on postcolonial/decolonial signification and its possibilities:

renasce das cinzas a água onde se espargem ilhas

ilhas como flores

ilhas que serão sempre deusas ignoradas

grávidas de trilhos

por onde sulcaram mágoas navegantes e náufragos. (136)

[from the ashes is reborn the water where islands are sprinkled islands like flowers

islands that will be forever unknown goddesses

pregnant with paths

through which navigating sorrows and shipwrecks may sulk.]

We can read the first line of this stanza as articulating the attempt at a postcolonial rebirth from the destruction left by Empire. Interestingly, Beja suggests that what is reborn is water itself, a substance that, due to its physical properties, cannot be burned, and therefore has no relationship with ashes. This would seem to imply a false destruction, or Empire's inability to contain the existence of cultures and gnoses, merely foreclosing them from Empire's textual universe. In this regard, Beja attempts to locate decolonial resistance by pointing out the limits of Empire's symbolic power where the annulment of non-imperial scenes of writing leads to their cultural destruction under the imperial sign of otherness. We can also read Beja's deployment of water imagery as standing for the perseverance of non-imperial signification and sites of articulation. In this indestructible material there are decolonial gnoses that give rise to islands, a potential metaphor for resignified terrains of collective identities.

Beja's work has often been characterized as elaborating island identities or referring to a povo ilhéu [island people]. In many ways, 'Terra' problematizes such a statement, or even enriches this particular strand of Beja's work, by working through the possibilities of decolonial signification by way of the imagery she evokes for postcolonial São Tomé and Príncipe. Importantly, decolonial narrativization, or the production of new meanings symbolized in the poem by the scattering of islands, is not portrayed through the formation of new islands, as the first two lines seem to suggest. Rather, the islands that will emerge will be born out of, enunciated over, the terrains of 
suffering and oppression - the 'seaborne grief and shipwrecks.' This seems to call for a decolonial narrativization that does not strategically forget such a painful past. Instead, such a narrativization must inscribe through it, as in the case of the middle passage, formulating new terrains of meanings and identities that, according to Beja's larger poetic œuvre, are never closed off or contained. As such, her work opens the possibility of a decolonial rearrangement of desire, similar to that which Ana Margarida Dias Martins points out in the novel Niketche: uma história de poligamia [Niketche: A Story of Poligamy] by Mozambican writer Paulina Chiziane. More specifically for our reading of Beja's poetry, Dias Martins suggests that such a rearrangement implies a reinvention of dominant structures of intersectionally based power (74).

We can argue that the poem's title is inherently polysemic, pointing to both earth as planet and, more importantly, to the constantly emerging and renegotiated signified terrains that comprise it. In this sense, the poem seems to gesture toward a postcolonial remapping; the formulation of a postcolonial sign-system in constant renegotiation through the infinite interplay of borders, as seen in 'Identidade.' This particular poetic mission of Beja is enacted in her poem 'Escuridão' ['Darkness'], also from Aromas de Cajamanga:

A sinfonia do tempo dilata-se no areal

da praia entontecida no teu ventre

a cúpula das árvores espreita a névoa do Cão

Grande

envolto na orquestra da brisa

o arco-íris multiplica as cores na vereda da

chuva ciumenta

por onde passa a memória da nossa infância agreste. (140)

[The symphony of time is dilated on the sand of the beach dizzied in your womb

the dome of trees peeks at the mist of the Cão

Grande

wrapped in the orchestra of the breeze

the rainbow multiplies colors in the path of the jealous rain

through which the memory of our rough childhood passes.]

The first line tellingly articulates a relationship between time and space that which is to be narrativized as the poem progresses. The titular darkness 
of night conveys, in itself, the overlap of time and space, the night sky being the spatial entity that envelops the immediate physical/visual field, but that pertains to a particular, albeit cyclical, period of the day. Equally notable is this rendering of time and space, particularly the night, in the feminine and maternal, itself in relation to the 'dizzying shore' that once again evokes a border imagery and Beja's overarching approach to postcolonial/decolonial narrativization.

This eventually leads to the evocation of the rainbow which 'multiplies the colors in the path.' Beja's deployment of the rainbow imagery and attributing to it a particular function - of multiplying colors - can be understood as the connecting of different identitarian terrains and intersections produced from Empire. This sort of rainbow, which implies also the joining of different sites of signification, will then multiply itself in accordance with the logic of Beja's infinitely reproducing borders and shores. As such, the evoked path toward decolonial signification is never a monolithic one, but one that is composed and persistently renegotiated by the interplaying borders that form it. Beja ensures, moreover, that this path does not diverge from its grappling against Empire by clarifying that its indeterminate path is always tied to the painful content of the past and the present.

In the time-space of the night's darkness with which Beja dialogues, and thus enunciates her own unfixed signifying chain, we come across the pain of the present, and its concomitant imperial pleasure and enjoyment:

festejam-se insônias

em tabuleiros de xadrez

abrem-se mãos e desmembram-se veias

onde perpassam sombras de Brasis longínquos. (140)

[insomnias are celebrated

on checkered trays

hands open and veins are dismembered

through which run shadows of faraway Brazils.]

Pain and pleasure in the context of Empire appear in intertwined, almost oxymoronic expressions such as the celebration of insomnia. Beja also performs a tentative mapping of imperial destruction by locating the 'dismembered veins' in 'faraway Brazils.' The plural form of Brazil is particularly curious as it refers to the early imperial Portuguese nomenclature for the colonial piece of land and circulating bodies therein. In this sense, Beja poignantly reminds us of the imperial epistemic violence of naming and signifying - the mapping of the imperial world is mutually potentiated by 
the physical violence enacted over bodies and spaces. The persistence of the evoked shadows of these 'Brazils' also underscores the constant decolonial tussle against Empire and its modes of global signification.

The postcolonial mapping performed here, from a decolonial gnosis, can be thought of as Beja's praxis of engagement with Empire. As a mapping, Beja's formulation of a tentative sign-system operates through a free-flowing mélange of historical signifiers pertaining to the violence of imperial meaning and knowledge, geographic landmarks, and Empire's subalternizing processes, including slavery. The ultimate goal of such a sign-system is to create a signifying field over and against that of Empire, one that fundamentally acts as a border space - a significational terrain where existing and emerging terrains and forms of intersectional consciousness (spawned from Empire or not) can rethink themselves and/or build new solidarities and open-ended collectivities. Beja appears to build on this sign-system in the next stanza:

a aragem tépida do teu céu da boca traz à lembrança flores de algodão que se espraiam nos areais vermelho-sangue de Fernáo Dias. (141)

[The tepid air of the roof of your mouth brings to mind cotton flowers that sprawl across the blood-red sands of Fernão Dias.]

Much like the decolonial scene of writing at work in the poem, the titular night continues to bring forth meaning to the open-ended postcolonial sign system, in this case, the memory of African slave labor evoked by the 'cotton flowers.' Within the context of Empire, as rendered in the poem, slave labor operates in strong relation to imperial mapping; hence the mention of Fernão Dias, a frontiersman of colonial Brazil whose charting of vast tracts of territory permitted its incorporation into the Portuguese possessions as well as into Empire's signifying field.

Beja notably uses the term espraiar, which can be translated as 'to sprawl' or 'disseminate.' The root of the word in Portuguese, praia [beach] is perhaps most interesting with regard to the poem's political engagement. Beja utilizes once again imagery of shores and borders constructed, in the case of slavery and slave-based economies, through displacement, diaspora, and the subsequent formation of myriad intersectional subject-positions. Here, diaspora forced by Empire-driven slavery points to the disseminated site of subaltern articulation spread across the globe. Having contributed deeply to imperial historicization and the right to signify implied therein, Beja seeks to 
rethink slavery, without eliding its profound consequences still felt today, by calling on the radical potential of the African diaspora within the proposed sign-system and decolonial path. For Beja, the slave subject-position, and the contemporary diasporic subject-position, always entails the potential for decolonial signification. The poem therefore attempts to open the border/ sign-system to slavery's dissemination of subject-positions, again, as a signifying field over and against Empire, from where to rethink selfhood and global time-space. The use of espraiar reiterates that the path toward decoloniality must, for Beja, be in constant negotiation and thus function as a borderland for the interplay of emerging and existing borders.

\section{Conclusion}

We can thus see a sort of progression in terms of Olinda Beja's political project and stance pertaining to Empire, across her poetry collections. Her first volume, Bô Tendê?, offers a multilayered reflection on the interpellation into imperial otherness from a nascent decolonial scene of writing. The contours of this scene of writing are then more fully fleshed out in her third collection, No País do Tchiloli, as a border entity in constant dialogic renegotiation with other borders/scenes of writing. Finally, her sixth volume of poems, Aromas de Cajamanga, formulates a praxis of decolonial writing, namely laboring toward a postcolonial sign-system from which to rethink global space and time away from and in opposition to Empire and its modes of signification. Throughout her work, Beja has laid a political trajectory deeply allied to decolonial forms of knowing and signifying, both local and global. The formation of a decolonial signifying field is thus predicated upon the constant exchanges and shifts between and among existing and future decolonial scenes of writing. 


\section{Transgendering Jesus: Mário Lúcio Sousa's O Novíssimo Testamento and the Dismantling of Imperial Categories}

W riters from across the Lusophone world have formulated ways to grapple with and against Empire's field of meaning, ranging from allegories of consumption to dealing with colonial specters and poetics of intersectionality. Mário Lúcio Sousa's novel O Novíssimo Testamento [The Newest Testament] (2010), in combining the religious, spiritual, and the fantastic, offers yet another path against Empire.

Sousa was born in Tarrafal on the island of Santiago, Republic of Cabo Verde in 1964, 11 years prior to independence from Portugal. Aside from being an established writer of fiction, poetry, and theater (which he also directs), Sousa is a renowned musician. He is founder and lead singer of the Cape Verdean musical collective Simentera, an acoustic group fusing popular national musical genres such as Coladeira, Morna, and Funaná. Like his literature and dramaturgy, his music is also politically engaged. In addition to integrating the genres mentioned above, for instance, the group's repertoire includes slave hymns from both Cabo Verde and continental West Africa. Beyond evoking colonial violence, this practice breaks with elitist constructions of Cape Verdean popular music of the early and mid-twentieth century, which sought to evoke a cultural and racial separation between 'Europeanized' Cabo Verde and the African continent. We can thus consider Sousa's work in music, literature, and theater to be undergirded by artistic engagements with power and cultural politics. In addition to artistic endeavors, he earned a law degree from the University of Havana and served in the Cape Verdean parliament for five years.

While Sousa may have few recollections of direct experience of Portuguese colonial administration given his date of birth, he is arguably part of what we may consider a generation of Lusophone writers who grapple with the specificities and legacies of Portuguese colonialism, as well as with broader contemporary forms and manifestations of power based on race, gender, 
class, sexuality, and (dis)ability. This sort of engagement is very much evident across his entire artistic cuvre. Sousa was forced to confront one of those legacies head-on as an adolescent. Following the death of his parents when he was 15, he lived as an orphan in the Cape Verdean military base in Tarrafal, a building that had been Portugal's concentration camp for colonial dissenters. The historical weight of that particular experience surely had an impact on his view of the postcolonial nation-building project as it grappled with all that colonialism left behind. At another level, though, this experience may have also contributed to the proposal against Empire we shall explore in O Novissimo Testamento - the ability to resignify and transform what Empire had already signified. Regardless of the violence with which members of Empire performed the meaning of that particular space, it can become unfixed once again and postponed, as Derrida reminded us in Chapter 3, and thus reformulated.

The events of the novel's plot take place in the remote Cape Verdean village of Lém, on the island of Santiago, during the early 1970s, the final years of Portuguese colonial rule. There a devout elderly Catholic woman lies on her deathbed at the end of a life lived in practical solitude with the exception of two young women referred to as her adopted granddaughters and known simply as the Marias. Living a life of total adherence to Catholic doctrine while shunning any form of pleasure not tied to her faith led to her becoming known as 'a mulher mais beata' ['the most devout woman']. Feeling the end of her life approaching, with both Marias by her bedside, she requests a photographer instead of a medical doctor, arguing that a photograph prolongs life more than a doctor's visit.

The one photographer of Lém promptly arrives and snaps a photo as she takes her last breaths. At the very moment of the camera's click, her body physically disappears into the camera. Residents of Lém quickly gather upon hearing news of the curious incident, and within the two days the photographer needs to develop the film, thousands of people from around the world flock to Lém to bear witness to the unfolding events. The developed photo depicts what everyone perceives to be a miracle: superimposed upon the image of the bedridden elderly Cape Verdean woman is the image of Jesus Christ, in its dominant European form. This ultimately leads to the arrival of millions of people from around the world, both to get a glimpse of the photograph and to wait for someone to step out of it. The self-conscious narrator jokes that he fears the island will sink due to the overcrowding. Although this does not happen, the population of Santiago and the remaining islands constituting the archipelago is multiplied 144,000 times. Within the immense crowds throughout the islands, it becomes impossible, according to the narrator, to distinguish the race, ethnicity, nationality, or gender of any 
person to the point that such imperially inaugurated categories of human classification became unnoticeable, while also avoiding Lusotropicalist erasures of race as a socially relevant category. This decentering of imperially formulated categories is very much the narrator's utopian interpretation of the demographic predicament at hand, but it is also a sort of foreshadowing of the ethical project to come later in the novel.

The development of the photo also restores the elderly woman's body back to the physical realm of human life, but now as Jesus. In other words, the messianic figure of Christianity repeatedly gendered and racialized by Christian liturgies and visual arts throughout the centuries to embody white masculinity, concurrently with the formation of the West, now walks the earth in the body of an elderly African woman. Jesus, now referred to and addressed with feminine pronouns, interestingly carries around the photograph of the revelatory superimposition of the Western rendition of Jesus's image as a manner of identification as the messiah, although news had spread almost universally that she was the reincarnation of Christ. Aside from carrying the photo, Jesus is accompanied by the two Marias and Clara, a resident of Lém, through whom Jesus speaks.

Before the reincarnation is fulfilled, however, the dominant Western image of Jesus is interestingly unpacked. Called to the elderly woman's home following the disappearance of her body into the photographer's camera was a local priest known simply as father Renan, a multilayered reference to Ernest Renan, whom the novel cites in an epigraph. The reference reminds us of Ernest Renan's place within religious thought as well as his contributions to imperial notions of racial difference, particularly in his revision of Jesus's biography, arguing in Life of Jesus that Christ transformed himself from Jew to Christian, thus Aryanizing the messianic figure. The deployment of a character named Renan who now witnesses the transformation of the male Aryan Jesus into the body of an African woman is both an allusion to the imperial construction of a messianic figure at the service of European expansion and right to global power, and a clever response to Renan's imperial brand of narrativization. The narrator effectively captures a piece of Renan's project in Life of Jesus, namely that of depicting Jesus as a human being rather than a divine entity, and takes it in a decolonial direction by stripping Christian religious meaning from the figure of Jesus altogether. For the many travelers visiting Santiago for a glimpse of the photograph, Father Renan attaches a description of the image of Aryan Jesus captured in the photograph:

não hesito em dizer que se trata de um homem caucasiano que media os seus bons um metro e oitenta centímetros e que pesava cerca de oitenta quilos, tudo indica que terá sofrido muito nos últimos dias da sua vida, porquanto apresenta 
fluxos de sangue na cabeça, provenientes de várias feridas de perfuração na testa e no couro cabeludo, também terá sido espancado no rosto, apresenta feridas nos pulsos como se tivesse sido crucificado [...] na verdade, as constituiçóes da mão são demasiadas frágeis para suportar o peso de um homem de tal estatura. (Novissimo Testamento 52; emphasis original)

II do not hesitate to say that it is a Caucasian man of about one meter and eighty centimeters weighing about eighty kilos, he seems to have suffered plenty in the final days of his life, as he displays cranial hemorrhages due to various perforations on the forehead and scalp, he seems also to have been hit in the face, he displays wounds on the wrists as if he had been crucified (...) in truth, the composition of the hands is far too fragile to support the weight of a man of his size.]

The narration of the image by Father Renan is poignantly dry and straightforward, using cursory medical speech in stark contrast with the polish of historical revisionism characteristic of Ernest Renan. The image of an Aryanized Jesus Christ is stripped of its religious meaning and supplemental value - that which furnishes the commodity or symbol with its perceived magic. In this sense, the narrator separates the image from its implied will to truth so central to Life of Jesus's project of inscribing the superiority of whiteness by revising the pigment and religious/cultural whiteness of Christ. In describing the image in purely physical terms, Father Renan comes close to placing the body of the Christian messiah in the Real, reducing it to its positive physiological being, stripping it - as well as its whiteness, masculinity, and ableism - of its supernatural meaning and thus its religious value. In performing this separation of the corpse (the Real) from the signifiers of religious divinity (the symbolic), this passage effectively delinks the text of religious meaning from its imperial writing.

In her reading of Sousa's novel, Catarina Martins points out its efforts to destabilize and revise European Christianity as it was imposed by colonial authorities (37). More specifically, 'Sousa attacks Christianity's core, not because it is un-African, but more importantly because it is inhuman [...] we witness an attempt to develop a religious message that will do justice to a broad concept of Humanity' (37). We can pinpoint the contours of this greater Humanity taking shape in the form of a persistent questioning of an array of imperial claims to normativity. By offering the above example of Christianity's relationship with Empire, the former a part of the latter's discursive field, the narrator sets the scene for both the reincarnated Jesus's experiences in the realm of intersubjective meaning and her mission to change this realm. 


\section{Dialogic Epistemes}

The sudden reincarnation of the messianic figure, now as an embodiment of otherness vis-à-vis the image of historical universality in terms of race, gender, age, and ability as the standard bearer of Westernness appears, at first glance, to inaugurate an end moment. This would be the eschatology of History through a ground-clearing motion that brings forth a zero moment or new beginning. As the narrator warns soon after the development of the photo, however,

E tudo está ainda no começo, apenas no começo, pois a ideia de que a história termina aqui, que depois da resurreição tudo acabou, é errada, é exactamente aqui que começa toda a história, e tudo que se vai ouvir nos próximos tempos é isto mesmo. (Novissimo Testamento 51)

[And this was merely the beginning, just the beginning, as the idea that the story ends here, that after the resurrection everything ends, is false; it is precisely here that the whole story begins, and all that will be heard in the coming time is exactly that.]

The reincarnation does not simultaneously deliver a new realm of intersubjective meaning. Rather Jesus, now in the terrestrial body of a black elderly woman, is very much placed into the signifying field of Empire. Despite being widely recognized as the reincarnation of the messianic figure, Jesus must confront the ways in which her body is inscribed in terms of race, sexuality, and gender.

As the reincarnation of Jesus, she is also ensnared by the religious writings pertaining to the established canonical notion of the Christian messiah. In a chapter titled 'Sermão da Montanha' ['Sermon on the Mount'], referring to the portion of the Gospel of Matthew (chapters 5-7) that presents arguably the most-recited series of Jesus's moral teachings, Jesus cannot decide whether to simply follow what has been written (what she apparently said according to the Scriptures) or break with the Gospel:

estaria Jesus a ser outra vez vítima de Si própria?, refém da sua própria sorte?, cumpridora eleita de uma missão que nunca escolhera?, dona de uma vida já escrita?, com capítulos e versículos em que Ela não participara? (Novissimo Testamento 110)

[was Jesus once more a victim of Herself? A hostage of Her own destiny? The elected agent of a mission She had never chosen? Owner of a life already written, with chapters and verses in which She had not participated?] 
Jesus quickly realizes that her actions are inseparable from a realm of desire that has written and has read her prior to her reincarnation.

This is ultimately the crux of subjectivation, which we have explored in previous chapters - occupying a signifier that has already been inscribed, one whose desire has been tentatively synchronized with that of power; whose words, in her case, have already been ventriloquized through power's writings in religious form. In looking to establish her own voice and site of signification, Jesus must confront the scenes of writing that had imperially created and ensnared her. The scriptures, moreover, narrate the actions of a messianic figure pertaining to a divergent subject-position, one grounded in imperial notions of racial and gender universality.

It is against this particular field of meaning - framing intersubjective relations and knowledge of time, space, and bodies - that Jesus realizes she must inaugurate a Third Age, that which comes after the Current Era. This new age of intersubjective reality will not appear and impose itself spontaneously, however. As Jesus explains, it is one based on a dialogic intersubjectivity, as opposed to the monologic scene of imperial signification:

Jesus estava ali para ver e ouvir, era inaugurada com Ela a era da palavra, a Terceira Idade do Mundo, em que o diálogo terá a força do Verbo, e Jesus ali estava para atender o seu povo, gente que até vergonha de falar tinha porque desconhecia a palavra certa. (Novíssimo Testamento 103)

[Jesus was there to see and listen, with Her was inaugurated the era of the word, the Third Age of the World, in which dialogue will have the power of the Word, and Jesus was there to tend to her people, people who even felt ashamed to speak because they did not know the right word.]

In potentiating the emergence of new sites of signification, the displacement of the monologic foundation of reality also opens a space for the articulation of new forms of knowledge, the production of which had been barred by Empire. This sort of play and inversion between margins and centers is not new to works by Mário Lúcio Sousa, namely his plays, as Christina McMahon explores in 'Sozinha no Palco (Lusófono)?' (2014).

A large portion of the diegetic action follows Jesus as she listens to the pain, quotidian challenges, and maladies faced by the multidão [multitude] who search for a miraculous solution to these problems. Before such an enormous crowd living in anguish - brought on, in many cases, by contemporary power - Jesus reflects that 'detrás das palavras vulgares do sofrimento estava um mundo em decadência' ['behind the vulgar words 
of suffering was a decaying world'] (Novissimo Testamento 103). In listening and permitting dialogue, Jesus allows the inscription of each individual to signify their own suffering and bring forth their own knowledge of reality. While many members of the multitude communicate their ordeals overtly pertaining to Empire and its system of differences, especially regarding disability, many of these also take on an element of the fantastic. This is the case, for instance, of a young boy able to button and unbutton the clothes of others simply by whistling, or a man who chose to live in trees rather than on the ground. The latter had become known in the village as one of the so-called 'endemoninhados' ['the possessed'] - a group feared and marginalized due to illness, mode of living, or (dis)ability.

The multitude originally brings Jesus to the endemoninhados in order to cure their difference. Jesus listens attentively to both the endemoninhados and to others involved (witnesses, family members, etc.), but refuses to perform any miracle. In the case of the man living in the trees, for instance, she proclaims to both him and the multitude: 'Deixai-o nas alturas' ['Let him live in the heights'] (Novissimo Testamento 155). The narrator captures the significance of Jesus's resolution:

E aquele homem voltou à sua vivenda, e os endiabrados pularam de alegria e todos os que estavam presentes, outrora temerosos do aspecto dos energúmenos, ficaram surpreendidos, e eis que, definitivamente, entenderam aqueles que sabiam e queriam entender o seguinte, um pormenor, isto é, que os chamados bastardos pelos próprios progenitors, afinal, não o são aos olhos de Jesus, e, se bastardos foram, já não o eram aos olhos do povo, porque quando pularam de alegria, fizeram-no não como manifestação de protesto pela liberdade própria, mas pela simples liberdade do outro. (Novissimo Testamento 155)

[And that man returned to his home, and the possessed jumped with joy and all those present, who had been scared by the appearance of the possessed, were surprised, and henceforth those who knew and wanted to understand definitively understood the following: that those called 'bastards' by their own progenitors were not so, after all, in the eyes of Jesus and, if they had been bastards, they were no longer so in the eyes of the people, because when they jumped with joy, they did so not as a protest for individual freedom, but to celebrate the freedom of the other.]

Jesus successfully undoes the dominant categories of human corporal classification and the way in which bodies are known and interpreted within the realm of intersubjective meaning. The so-called 'possessed' are 
no longer categorized as such among the multitude. In doing this, Jesus also displaces the gaze that oversees the reproduction of power through such categories, including disability as an imperial classification and inscription of otherness. In this sense, she also gestures toward an altering of the terms by which subjectivation repeatedly occurs within Empire. The performance of subjectivity within Empire is remolded to no longer follow imperial knowledge and classification of bodies.

Through this decentering of the interconnected system of classification and gaze of Empire's signifying field, dialogism is potentiated. As such, the 'other,' as a body/object signified through imperial difference and knowledge, inches closer to freedom from imperial meaning. The dismantling of categorizations of otherness becomes a project against imperial epistemic violence, a term brought forth within the field of postcolonial inquiry by Gayatri Spivak in 'Can the Subaltern Speak?' (1993), drawing on Foucault's exploration of discourses of madness in eighteenth-century Europe. The term refers, in both Foucault and Spivak, to a field of knowledge serving as a means of domination over the groups contained within said field. In regard to Foucault's example of epistemic violence and overhaul, Spivak reflects: 'But what if that particular redefinition was only part of the narrative of history in Europe as well as in the colonies? What if the two projects of epistemic overhaul - European madness and colonial normality - worked as dislocated and unacknowledged parts of a vast two-handed engine?' (31).

As Spivak suggests, madness and normality, or difference and normality, are two sides of the same coin of imperial epistemology. In the moment Jesus abolishes signified difference/abnormality, she also dismantles normality and the bodies ensnared within that epistemic dichotomy. This deconstruction also dislocates the power to signify from any notion of normality. In this case, access to participation in collective signification is now afforded to all and on a level field, not guided toward Empire's desire for the reproduction of a power spectrum. Jesus had already signaled this intention earlier in delinking herself from established scripture, urging the multitude to separate their interpretations of phenomena from those found in scripture: 'Náo me tomeis por aquilo que julgais que sou, mas por aquilo que vós sois' ['Do not take me to be what you judge me to be, but as what you are'] (Novissimo Testamento 115). In yet another act of delinking, Jesus separates the desire of the subject from the desire of Empire, in its Christian doctrinal form. As far as is possible, she attempts to present desire as a single-entity operation, perhaps not in the sense of a subject and desire isolated from ideology, but an open-ended, unguided desire of the subject within a revised field of meaning and relationship with said field. This would reformulate the subject by inaugurating desire as 
de-synchronized from an ego-ideal - the function within a spectrum of power and its implied field of meaning 'from where we are being observed' (Žižek, Sublime 116).

The ego-ideal, in acting as the gaze that reaffirms the subject's good standing in relation to the desire of the big Other (power's field of meaning), ultimately serves to reaffirm the subject's place within this field. As an ideological and psychic function, the ego-ideal is also intricately tied to the imperial modes of epistemic violence which the reincarnated Jesus seeks to eliminate. The ego-ideal's fundamental function for the big Other in terms of the subject's desire pertains to identity - particularly the performance of it in a mode synchronized with Empire's desire for the reproduction of its spectrum of power. As a constellation of subject-positions/signifiers that comprise this realm of power, the individual is subjectivized to fit one of these positions, first introduced in the mirror stage as ideal ego. The latter, as well as the constellation of subject-positions, is in turn produced by way of imperial taxonomies of bodies in terms of race, gender, ability, health, class, and sexuality. The ego-ideal thus provides the link between Empire's desire and the subjectivized performance of identity within and across these imperial categories. In this regard, Jesus attempts to delink the ideological foundations and inner apparatuses of imperial subjectivation.

In doing so, Jesus is also careful to not simply take the place of the ego-ideal, to not recircuit desire in any particular direction. This begins to become evident from the last quote above: 'do not take me to be what you judge me to be, but as what you are' (Novissimo Testamento 115). When she decenters herself from desire, desire seems an unhinged phenomena with neither an ego-ideal nor an ideal ego derived from imperial knowledge and classification. Furthermore, Jesus performs a new relationship with knowledge, separating herself from it, from the subject-position Lacan calls 'the subject supposed to know' or 'supposed subject of knowledge' (Lacan, Seminar XI 232). Lacan's use of the term refers mainly to the role of the analyst in the clinical setting, but we can find a similar dynamic in the initial relationship between Jesus and her followers, who seek her guidance and resolutions. In calling on her followers to replace her with themselves, as in the quote above, she displaces her agency over knowledge - a gesture that goes hand in hand with her vision of a dialogic intersubjective sphere of meaning. 


\section{Rewriting the Dark Continent and Decentering Masculinity}

The most notable aspect of Jesus's goal of inaugurating a dialogic realm of social life resides in her deconstruction of masculinity and its claim to power, namely its power over signification. Her incursion into masculinity, namely its performance and its relationship with power, begins with the first time she speaks to the crowd of followers, her version of the 'Sermon on the Mount.' One of the first questions she is asked after gesturing toward the delinked desire of the multitude, and separating herself from it, goes as follows: 'Senhora Jesus, sendo Vossa Santidade mulher, que me dirá do adultério?' [Madame Jesus, since Your Holiness is a woman, what can you tell me about adultery?'] (Novissimo Testamento 116). Before giving us Jesus's reply, the narrator provides the ideological backdrop to her eventual answer, pointing out adultery's masculine scene of writing by noting that, regarding adultery, 'as opiniôes dos homens, as únicas até hoje conhecidas' ['the opinions of men (are) the only ones known today'] (Novissimo Testamento 119).

The narrator interestingly frames adultery as a discursive construction produced for and by the performance of masculinity in its relationship with compulsory heterosexuality, and the parallel silencing and masculine inscription of women's desire. The parameters of the definition and application of adultery as both a practice and a criminal act are, as the narrator suggests, negotiated by men. This brief reflection points toward a masculine sphere of articulation (explored in chapters 4 and 5) that surveys, categorizes, and defines bodies and their actions within a realm of intersubjective meaning in which masculine power is couched. The narrator's classification of masculine opinion regarding adultery as 'the only one known today' speaks to the masculine power to signify and its monologic grip on the meanings that inform social experience.

Along these lines of inquiry, Jesus's reincarnation and subsequent journey through Empire as a woman consistently grapple with the products of this masculine inscription of bodies and actions. As an example of this grappling, the novel contains several passages that can be read as engaging Freud's infamous conception of women's sexuality as a 'dark continent for psychology' (Standard Edition XX 212). Freud's stance has come to embody both the centrality of the male body as phantasmatic totality, its historical universality, and the foreclosing of non-cisgendered male identities from signifying their own bodies and actions. The premise is, of course, that such bodies are 'too other' to have the right to signify. Sander Gilman lucidly extrapolates the imperial categories of otherness at work in Freud's theorization of female sexuality, particularly those of illness and abjection, by pinpointing Freud's movement from a 'suggestion of disease 
and difference into a discourse about the "blackness" (the unknowability) of the woman' (Freud 38). This unknowability goes hand in hand with the systemic quotidian barring from the signifying process.

The narrator's words also point to the other side of unknowability - the production of meaning over the unknowable. For every foreclosed site of signification, in other words, there is a series of signifiers of alterity. The Freudian question that comes in tandem with his proclamation of women's sexuality as a dark continent - 'What does woman want?' - marks the space over which women have been signified. This space is, of course, that of desire. In the masculine heterosexist-dominated sphere of articulation and historicization, from which women and non-conforming gender identities are barred, women's desire is a patriarchal inscription, circuited to the desire of the Other by way of the masculine right to signify. The imperial signifying process does not only produce categories and classifications of otherness, it attributes a desire to the othered body. This is, of course, the centuries-old formula of orientalism, Islamophobia, anti-Semitism, xenophobic rhetoric, and other hegemony-derived phobias and forms of hate. The other is signified as 'wanting' to harm; exploit resources; rape/be raped (another tired chauvinistic trope regarding women's desire); and corrupt the phantasmatic standard, norm, or moral fabric thereof.

In the briefest of sentences, in other words, the narrator refers to myriad layers of signification against which Jesus must battle. It is in response to the forces and products of imperial signification that, later in the novel, Jesus seeks exile on the uninhabited Cape Verdean island of Santa Luzia. Not only is it the only uninhabited island of the archipelago (of the ten main islands), it is, as the narrator reminds us, the only island bearing a woman's name. The reasoning behind Jesus's decision to seek exile on Santa Luzia invokes, once more, Freud's trope of the 'dark continent.' In Santa Luzia, the narrator tells us, Jesus

podia assim fugir às Escrituras, e se havia a ilha de Santa Luzia pelo caminho, não era, todavia, pela Santa que Jesus a elegera, mas antes por a ilha ser virgem e deserta, sem homens nas suas entranhas agrestes. (Novissimo Testamento 214)

[could, in this way, elude the Scriptures, and if the island of Santa Luzia was on the horizon, it was not because of this particular saint that Jesus selected the island, but rather because the island was virgin and deserted, without men in its rough entrails.]

Santa Luzia's past invokes much relevant imperial history, particularly that to which Freud's term refers. Due to its extremely arid conditions, Santa 
Luzia is deemed inhospitable in the long term, although it is a tourist site for brief visits. As such, it is the only island of the archipelago that resisted colonization and remained uninhabited, save for a small agricultural community that attempted to live there in the eighteenth century.

Santa Luzia's appeal to Jesus, the fact that it is deserted, allows the island to embody more than the 'unknowable,' but also the unsignifiable. The novel thus contorts the trope of the dark continent into a symbol of resistance - a space that masculine historicization could not incorporate into Empire. It is, therefore, in a place that has eluded dominant meaning that Jesus can in turn elude the meanings contained in the Scriptures, those that lay out the actions she is supposed to follow, the blueprint for her subjectivation.

It is equally important to note that her exile in Santa Luzia comes as a consequence of the death of João, her object of romantic desire. João appears to her earlier in the streets of Lém as an apparition while he is actually jailed in a nearby prison, presumably the colonial prison of Tarrafal. Before she can come into contact with him, he is beheaded in prison by the colonial authorities, thus invoking the story of John the Baptist to which his name refers (João being the Portuguese equivalent of John). Jesus believed the earlier apparitions of João were signs that she must seek him out. Although the narrator does not fully flesh out the contours of Jesus's romantic interest in João, perhaps in order to avoid speaking for Jesus's desire, the reader can nonetheless grasp Jesus's intention to live her terrestrial life as the messiah differently from her previous life as 'the most devout' Catholic. In that previous life, as she often remembers, she repressed all sexual and corporal desire in accordance with the imperial, patriarchal surveillance and control over bodies.

As the reincarnation of Jesus, she proposes to center the body as the means by which to know the world - spaces, objects, and other bodies. She begins to arrive at this conclusion when, following her version of the 'Sermon on the Mount,' she allows herself to be touched by the multitude as she walks through the crowd. The narrator reveals that:

experimentava agora Jesus o que era a paixão segundo a carne e percebia que qualquer coisa para chegar ao espírito tem de passar pelo coração, e para passar pelo coração, tem de passar pelos sentidos. (Novissimo Testamento 140)

[Jesus was now experiencing the passion of the flesh and understood that for anything to reach the spirit, it had to pass through the heart; and to pass through the heart, it has to pass through the senses.] 
Jesus thus initiates a rethinking of Christian doctrine to displace the primacy of 'spirit' for the agency of the body and the senses to understand the physical world. Her previous subjectivity - that which was known as the 'most devout Catholic' - was arguably close to what we may consider a 'pure subject of ideology', one that subscribes fully to the 'representation of the imaginary relationship of individuals to their real conditions of existence' (Althusser 109). In avoiding many forms of direct contact with the outside world, she had only come to know the world through the historicized representation of it.

We can thus also read the passage above as a championing of Spinozan immanence in the vein of Michael Hardt and Antonio Negri's stance against Empire. It is with regard to Spinoza and immanence that Hardt and Negri may offer insight into Jesus's own philosophical and ethical project in the novel: 'It is a philosophy that renewed the splendors of revolutionary humanism, putting humanity and nature in the position of God, transforming the world into a territory of practice, and affirming the democracy of the multitude as the absolute form of politics' (77). Reminiscent of Spinoza's humanism, Jesus's feeling of the multitude's touch provides her 'uma sensação tão humana, tão humana que jamais tão perto de Deus Jesus se tinha sentido' ['a sensation so human, so very human that Jesus felt closer to God than ever before'] (Novissimo Testamento 140). In this sense, for both Spinoza and reincarnated Jesus, the body's immanent contact with matter, less mediated by meaning/ideology emanating from and serving power, is central to a new realm of democratic social life. This would go hand in hand with Jesus's dialogic vision, as immanence would displace hegemonically articulated and disseminated meaning, and thus permit the individual to inscribe their own signifiers. The body thus becomes the instrument - rather than object - of knowledge; and meaning emerges a posteriori, rather than as a controlled phantasmatic frame of subjective experience.

Immanence and dialogism would thus constitute a new dialectic, mutually reproducing one another, making one another possible, each sublating the (re-)emergence of the other. The meanings that are inscribed through bodily experience are, therefore, barred from becoming frames of experience for others. An inscription of meaning at the level of the individual can, in other words, never become a hegemonic form of knowing, as it is contingent on intersubjective exchange. It is against this backdrop that Jesus enunciates her own desire in relation to the public as she searches for João.

Part of the new realm of intersubjective life which she seeks to build is the decolonizing of the body and corporal pleasure from the patriarchal schema 
of power. This also implies a decentering and contestation of heteronormative masculine and imperially oriented knowledge pertaining especially to women and queer identities. Such a shift in meaning surrounding the body also points toward a further shift in the terms by which subjectivation plays out. The body, across gender and sexual identities, themselves intersecting with racial and socioeconomic identities, is now allowed a greater space for pleasure, an expansion of the pleasure principle, the amount of enjoyment permitted for the balance of a new symbolic realm. This comes arguably in response to Empire's built-in privilege of enjoyment for men (explored in greater detail in Chapter 4), which she underscores in her 'Sermon on the Mount' in the context of the masculine discursive construction of adultery as an apparatus of control:

Ouvistes o que foi dito aos antigos, Não cometerás adultério, e que qualquer que atentar numa mulher para a cobiçar, já em seu coração cometeu adultério com ela, Eu porém vos digo desde esta minha condição, sendo assim, os homens, a não ser que em seus corações haja amor, são todos adúlteros e disto não escapam o próprio Adão com Eva e Lilith, e mais vos digo, se os homens assim se comportam todos, desde os tempos dos tempos, então é o adultério que deve ser abolido. (Novíssimo Testamento 119; emphasis original)

[You heard what was said to the ancients, Thou shall not commit adultery, and that anyone that covets a woman, has already in their heart committed adultery with her. I, however, from my standpoint, tell you that, unless they have love in their hearts, men are all adulterous, and from this there is no escape, not even for Adam with Eve and Lilith, and what is more, if all men behave in this way, since the beginning of time, it is adultery that should be abolished.]

What may seem, at first glance, to be a broad generalization of men as inherently adulterous, speaks to the ever-present possibility of masculine enjoyment in adultery, an enjoyment from which women are barred. Adultery, as part of the official laws regulating intersubjective life, what Lacan calls the Law, invokes a socially constructed pleasure principal - the parameters of pleasure (sexual or otherwise) that a subject may access within the limits of the Law. Enjoyment, as discussed in Chapter 4, is for Lacan pleasure beyond the Law. Like Catarina in Chapter 4, Jesus's reflection on adultery leads us to confront the heteronormative masculine enjoyment sanctioned by Empire, a breaking of official Law that, more importantly, reproduces and reinforces the imperial spectrum of power and field of 
meaning. In other words, the enjoyment allowed to men, as in the example of adultery, performs and reinscribes masculine power. In this regard, Jesus does not approach adultery as merely an act, but as a legal and judicial edifice that is unequally enforced. To abolish adultery as a legal apparatus would thus diminish the space specifically designated for masculine enjoyment and privilege - in relation to the barring of women from enjoyment and the significational repercussions thereof.

This leveling of the plane of pleasure and enjoyment is merely a part of the new civilization Jesus wishes to construct, grounded no longer in the repression of pleasure for the sake of a paradisiac afterlife, but in the centering of pleasure as the worship of life itself:

ficaria decretado de Si para Si que, a partir daquela hora, o culto seria o culto da vida, seria a vida todo o seu acatamento, seriam os seus ensinamentos a adoração da vida, sobre a vida Jesus edificaria o seu altar, sobre uma nova vida construiria a nova civilização, da vida implantaria uma nova cultura, faria da vida toda a devoção, seria viver a única homenagem, tudo se passaria a fazer em honra da vida [...] pregaria como religiáo unicamente a vida [...] para que juntos adoressem a vida como a Deus, que, alias, passarão a significar a mesmíssima coisa e constituirão uma única entidade, Deus será Vida e Vida será Deus. (Novíssimo Testamento 174)

[it was to be decreed by Her that, from that point forward, worship would be the worship of life, all deference would be to life. Her teachings would be on the worship of life, upon life Jesus would erect Her altar, upon a new life She would construct a new civilization, from life She would implant a new culture. All devotion would be to life, to live would be the only homage, everything would be done in honor of life (...) life would be the only religion to preach (...) so that together all would adore life as if it were God, which would, therefore, come to mean the exact same thing and would form one single entity. God will be Life and Life will be God.]

Ushering in such a revised collective view of humanity and approach to subjective experience entails for Jesus an undoing of both the existing view and the imperial forces that have ideologically engendered and reproduced it. 


\section{Undoing Masculinity and a Move Beyond Gender Categories}

It is with the objective of shifting the aforementioned collective view of humanity and intersubjective relations that Jesus centers her attention on the violent performance of masculinity. In the same paragraph of reflection as the previously cited passage, the narrator relates Jesus's engagement, as a woman, with the performance of masculinity and its quotidian excesses:

agora a diferença é monumental, observa a postura de uma mulher, uma mulher não baba os copos, não sorve de um hausto um trago sem o ver sequer, uma mulher não arrota no final de gole, uma mulher não pega num copo como se fosse uma pedra, certamente que não, uma mulher năo brinda com esse jeito de lutador grego nas tabernas, espancando os vidros, separando os ombros. (Novíssimo Testamento 175)

[now that difference is monumental, observe the demeanor of a woman, a woman does not slobber on cups, does not slurp a drink all in one go without even looking at it, a woman does not belch at the end of a sip, a woman does not grab a cup as if it were a stone. Certainly not, a woman does not toast with that attitude of a Greek wrestler in the taverns, slamming down her glass, spreading her shoulders.]

This particular passage leaves plenty to unpack, namely its essentialist gendering. As Martins notes regarding the plot's ushering in of a new brand of human relations through the subaltern experience of a black woman, 'this statement however falls into some traps from a feminist point of view: it presents a mythical womanhood that is still stereotypical and builds upon a rather traditional conception of binary sexual identities' (39). Though this passage - and others throughout the novel - lacks a degree of critical nuance in relation to the dominant constructions of gender and sexuality, it nevertheless points in an interesting direction regarding gender identity and the imperial categorizations thereof.

Despite, or rather through, its gender essentialism, the passage underscores the development of a gender binary into which subjects are interpellated and formed within Empire. Working within such a problematic binary, the passage highlights the fixed movements and actions of everyday hyper-masculinity which, through imperial gender interpellations, are not permissible to women. In barring women from performing identity through these performative signifiers, the latter have become part of the masculine lexicon of power and privilege within Empire. Despite evoking a stereotypical form of womanhood, within the context of the imperially engaged plot, we are directed toward how such a stereotype has been formed and historicized. 
The stereotype, ideal ego of womanhood for the reproduction of imperial patriarchal power, is one that is historically calibrated, through patriarchal circuits of desire, to be the rigidly formed binary other of masculinity and the everyday performance of its own power, which the narrator points out.

The shifts in gendered power suggested in the passage thus begin with an inversion of the structure constructed by current power, before undoing the structure itself. The shift, in other words, comes from the imperially formed subject-position of gendered subalternity. This is also the case with racialized subalternity in the form of the resurrected Jesus, as the intersectional embodiment of imperial categories. One can argue that this is part of the novel's ethics of anti-imperial engagement in the rethinking of imperial categories, toward their potential undoing, which is initiated - significantly - from the ontological sites of subaltern subject positions as they were created by and within Empire. Undoing all meaning through one divine gesture seems impossible to the reincarnated protagonist. Challenging and inverting Empire is, instead, a struggle to be led by those in subject-positions that have most endured Empire's effects.

The characterization of masculinity offered here takes particular aim at its quotidian violence that becomes part of the masculine body schema through imagery such as 'Greek wrestler' and 'slamming the glass.' From here, we are led to ponder the role of masculinity within power, and especially in the reproduction and reinscription of the evident gender binary. From this tracing of a normative masculine body schema and performativity, Jesus ultimately makes the connection to the monologic grip on historicization and the realm of intersubjective meaning that is concomitant with various forms of social compartmentalization, uneven flows of capital, and the discursive production of otherness and normativity. Herein lies the core of the novel's mission in transgendering and re-racializing Jesus; it is more than a diegetic device to question the self-signified legitimacy and universality of white masculinity. Rather, the novel appears to think through a new mode of conceptualizing interpersonal actions away from what is presented as the abject brutality of masculine inscription.

In opposition to this, the transgendering of Jesus, the shift in subject-position from which to view humanity, implies what the narrator refers to as 'estética' or 'aesthetics' with overtly decolonial contours:

estética no acto de viver mesmo, nos mais corriqueiros imundos actos do dia-a-dia, e cada coisa terá o seu antídote natural, estética na paz significaria continuar, estética na guerra significaria parar, estética na ira significaria ria, estética no sexo significaria erotismo, estética em mim significaria tu, estética na abundância significaria economato 
significaria partilha significaria unidade significaria nós significaria todos, sem vírgula nem reticências. (Novissimo Testamento 175)

[aesthetics in the very act of living, in the most quotidian and banal acts, and each thing will have its natural antidote, aesthetics in peace would mean to continue, aesthetics in war would mean to cease, aesthetics in ire would mean to laugh, aesthetics in sex would mean Eros, aesthetics in me would mean you, aesthetics regarding abundance would mean economics would mean sharing would mean unity would mean us would mean everyone, with no commas or ellipses.]

The term 'estética' thus seems to imply not only a shift away from violence and discursively constructed inequalities, but also a shift toward dialogism, once again. This passage, however, takes dialogism even further, connecting it to a larger outcome underscored in the last lines of the passage - a shift toward collective thinking without the aforementioned imperial taxonomies of human life. This would begin with an effacement of masculinity as a collection of signs and performances, and through which imperial power and its taxonomies of life are carried out.

Jesus's actions immediately following this reflection effectively tie all these ideas together. She quickly decides to put this 'estética' into practice at a small local tavern with Clara and the Marias. There she faces the imperial field of meaning orchestrated by the violent scenes of writing she aims to displace. The four women take their seats at a table as the regulars stare. They are greeted by a server, to whom Jesus declares through the voice of Clara: 'Vim provar o vinho' ['I came to taste the wine'] (Novissimo Testamento 177). Her statement provokes much surprise among the onlookers, as the narrator tells us:

E pronunciou Jesus com água na boca aquelas palavras, como se costuma dizer, para dupla surpresa de todos, inclusive das Marias, que sabiam que tal comportamento ia, de uma assentada, contra duas regras da tradição, a primeira, pelo facto de Jesus ser mulher e, a segunda, por ser Jesus Jesus, isto é, por ser Jesus quem julgavam os outros que Ela era, pois, como se sabe, nesses mandos dos costumes e das tradiçóes, não importa o que tu és, ou o que julgas ser, mas sim aquilo que és na cabeça dos outros, ou o que significas para os demais, concluindo daí que Jesus era efectivamente aquilo que o povo pensava dela. (Novissimo Testamento 177)

[And so Jesus, her mouth watering, proclaimed those words to the double surprise of everyone, including the Marias, who knew that 
such behavior was simultaneously in opposition to two traditional rules: first, due to the fact that Jesus was a woman and, secondly, as Jesus was Jesus, that is, for being the Jesus the others perceived Her to be, since, as we know, as far as traditions and customs go, it does not matter who you are, or who you think you are, but rather, what you are in the minds of others, or what you mean to the outside world, concluding from this that Jesus was precisely that which the people thought She was.]

The passage makes clear once more that Jesus is being read, her body circulating in a realm of textuality to be interpreted. Jesus's response to this and the subsequent consternation of the crowd and service staff is to undo the texts that govern the interpretation of bodies - in this case, those pertaining particularly to gender difference and performance. The texts that construct the notion of woman - those to which Jesus must adhere through performance - dictate 'proper' and 'normative' actions for women within the space of social meaning. These texts governing social interactions also enunciate the bar as a physical space primarily for the performance of masculinity. It is also one in which women unaccompanied by men are read in particular ways. These implications undoubtedly factored into Jesus's decision to go to the bar following the previous reflection on masculinity and its social narrativization. Although the passage operates by way of a strict gender binary, Jesus's identitarian performance appropriates gendered signifiers of both sides of the binary and temporarily effaces the legibility of both, and thus avoids a performance of gender that falls into the patriarchal heteronormative stereotype of womanhood.

Jesus insists, once more through the voice of Clara, on being served without the reading of her body and actions, a reading that infringes on freedom and impacts desire while compromising, moreover, the goal of a collective dialogism. After Jesus, Clara, and the two Marias are served their respective glasses of wine, Jesus raises hers for a silent toast with the entire bar, leading to a solemn 'momento de alto silêncio e de uma grande comunhăo' ['moment of supreme silence and great communion'] (Novíssimo Testamento 197) which, more importantly,

causou uma breve exaltação e muita cumplicidade, e todas as antigas diferenças se esvaíram momentaneamente nos pingos de bebida que iam caindo dos copos, e assim como desapareceram as gotas também sumiram as desigualdades, e porque a ocasião era especial mandaram os homens da taberna que fosse servido mais vinho, isto é, na linguagem tabernácula, que fosse a todos presentes servido o vinho, 
a todos, livremente das suas condições, fossem elas de género ou de espécie. (Novissimo Testamento 197)

[caused a brief exaltation and much conviviality, and all of the old differences dissipated momentarily in the drops of drink that fell from the cups, and as the drops disappeared so too did the inequities, and because the occasion was special the men in the tavern ordered that more wine be served, that is, in the tavernacular language, that all present be served wine, regardless of their respective conditions, be they of gender or species.]

For this brief and fleeting moment, the imperial field of differences is suspended. Although the narrator mentions, at different points, Jesus's mission to engender a new era in which 'fossem as mulheres e os homens todos iguais' ['women and men were all equal'] (Novissimo Testamento 177), the manner in which she attempts to inaugurate this new age of intersubjective relations implies, at one level, a decentering or effacement of masculinity and deconstruction of its performance. On another level, spawning this new age, of which decentered masculinity would be a part, seems to suggest an abolition of the texts that inform gender categories.

Jesus's very act of entering the bar and demanding wine appears to offer an example of this. Coded as a masculine act or, at the very least, one that is not characteristic of dominant/imperial/bourgeois notions of feminine propriety, she purposefully performs against her perceived gender identity within the realm of meaning that aims to establish the relationship between genitalia, gender, and sexuality. We can thus approach Jesus's actions here as an example of what Judith Butler coined 'gender insubordination.' Butler's term refers to an act that exposes normative gender and sexual identities 'as an incessant and panicked imitation of its own naturalized idealization' ('Imitation' 314; emphasis original). The topic of gender performativity is one that Butler has revisited across numerous books and essays spanning nearly two decades. In her later Undoing Gender (2004), Butler elaborates further on acts of gender insubordination and what their implications may be, drawing a parallel between an individual's 'doing' of gender in their own way and the 'undoing' of dominant notions of personhood.

Along similar lines, by effacing the legibility of gender distinctions and categories, Jesus carves out a space for free assumption of gender identities that demonstrates a radical awareness against gender essentialism. This is an awareness that gender performance resides in a plane of socially constructed meaning where sexism, homophobia, and transphobia also reside. Jesus's enactment of masculinity displaces it as a biological given and prompts the 
reader to think of masculinity, or other cemented/normalized gender identities, as a performance, as 'an imitation for which there is no original' ('Imitation' 313). In this sense, Jesus's actions here lay the groundwork for potentially critical gender nonconformity that informs the current life of Jesus as a trans identity. As Butler elaborates, 'identity categories tend to be instruments of regulatory regimes, whether as the normalizing categories of oppressive structures or as the rallying points for a liberatory contestation of that very oppression' ('Imitation' 308). It is in the sense of liberatory contestation against such categories of power and domination that Jesus affirms womanhood while also seeking to inaugurate the possibility of free gender inscription outside of the imperial texts that classify and gender bodies.

The temporary dissolution of differences that takes place in the scene of community at the bar comes about as a consequence of Jesus's act of gender insubordination. Performing an action coded as masculine while being read as a woman effectively delinks the action from a sign of gender distinction, which is precisely what Jesus calls for. Her action, that of entering a bar and ordering wine, is part of what we may consider a constantly negotiated and constructed dictionary of actions that make gender difference, in this case masculinity, legible as such. This is precisely Butler's argument when she clarifies performativity in Bodies That Matter: On the Discursive Limits of 'Sex' (1993): 'Performativity is thus not a singular "act," for it is always a reiteration of a norm or set of norms, and to the extent that it acquires an act-like status in the present, it conceals or dissimulates the conventions of which it is a repetition' (12). The repetition does not merely reinforce the repeated norm, it seemingly adds another layer of normativity and legitimacy that moves the norm further away from its Real inexistence. The repetition, in other words, adds to the symbolic realm and dictionary of norms by once again separating it from conventionality and reproducing its 'truth-ness.' To phrase it in yet another way, according to Butler, borrowing here from Jacques Derrida, the repetition of the acts coded as constitutive of a discursively articulated gender identity lends to that identity/category the semblance of truth which goes hand in hand with the legitimacy of normativity.

Butler seeks to drive home this argument by drawing on Derrida's notions of iterability and citationality. Like the act of signature in Derrida's essay 'Signature, Event, Context,' a performed gender norm acts as a ritual that is immediately recognized within a signifying field mainly due to its previous inscriptions, thus reproducing its existing legibility while aiding in the constitution of the subject:

performativity cannot be understood outside of a process of iterability, a regularized and constrained repetition of norms. And this repetition 
is not performed by a subject; this repetition is what enables a subject and constitutes the temporal condition for the subject. This iterability implies that 'performance' is not a singular 'act' or event, but a ritualized production, a ritual reiterated under and through constraint, under and through the force of prohibition and taboo, with the threat of ostracism and even death controlling and compelling the shape of the production, but not, I will insist, determining it fully in advance. (Butler 95)

The act reaffirms the identity/category of the body performing it as well as the signifying field in which it is recognized. In the case of Jesus's actions in the bar, however, the legible identity/sign of Jesus's body and the act recognized as masculine ultimately complicate one another and momentarily throw off the system of gendered meanings by which she is to be read. The repetition reaffirms the subjectivized body, performing it for the sake of maintaining a place in the symbolic realm. The repetition maintains the subject within meaning but, as a repetition, the act is but one of a pre-existing set of acts that constitute the subject, establishing parameters for normative gendered subjectivation.

More than merely acts, the signifying field of power also dictates which identities - emergent from previously performed acts in agreement with the ideal ego into which one is interpellated - are to perform which acts. In other words, part of the gender agreement implied by a rigid gender dichotomy does not permit much space for mixing and matching actions to perform. The interpellation into a gender sign obliges the gendered subject to follow the catalog of actions constructed, indexed, and made available to that particular sign if the subject is to exist in the realm of intersubjective life and meaning. By performing actions, or doing identity, from both sets of repeated and thus gendered actions, Jesus legitimizes a crossing of the gender border that momentarily shuffles both dictionaries of gendered actions into a larger non-categorized volume open to further additions. Her act thus inscribes into the field of meaning new terms by which to perform identity and personhood with the capacity to re-historicize an ideal ego or displace its phantasmatic point of origin altogether. In other words, Jesus's actions in the novel open the possibility of a gender non-conforming feminist discourse.

In this sense, Jesus's political project strongly evokes a profound undoing of boundaries in the vein of Donna Haraway's 'A Cyborg Manifesto,' very much a vision for late twentieth- and twenty-first-century historical transformation. Herein lies the socialist-feminist core one may read into O Novissimo Testamento - the fictional creation of a body/self that is both 
'a creature of social reality as a well as a creature of fiction' (Haraway 291), one that affirms identity while deconstructing the imperially created categories that aim to circuit identity in the form of subjectivation into the realm of power. Haraway's conceptualization of the cyborg figure captures Jesus's existence and ethical objectives vis-à-vis Empire: 'the cyborg has no origin story in the Western sense - a "final" irony since the cyborg is also the awful apocalyptic telos of the "West's" escalating dominations of abstract individuation, an ultimate self untied at last from all dependency' (Haraway 292).

Like the cyborg, moreover, Jesus in the novel's reincarnated appearance emerges almost spontaneously, with little knowledge as to the origins of the body/individual acting as the returned messiah. If we recall, the woman formerly known as the 'most devout' of Lém, had no known biological family and thus no family history inscribed in local public knowledge. As Haraway elaborates, this sort of detail itself implies a move against the foundations of Western imperial historicization: 'An origin story in the "Western," humanist sense depends on the myth of original unity, fullness, bliss and terror, represented by the phallic mother from whom all humans must separate, the task of individual development and of history' (292). The absence of an origin story for the reincarnated Jesus thus dovetails with her social project of challenging power-driven and power-reproducing categories of human life in favor of a greater freedom to signify across and beyond established taxonomies of bodies and desires.

\section{Conclusion}

Jesus's trajectory and actions in O Novissimo Testamento thus tie together her conception of a new era of intersubjective existence outside of Empire as well as the means by which to reach such a new culture of life. Representing and calling for an erasure of an imperial system of classification and knowledge dovetails with her dialogical vision of human relations in which a site of articulation does not seek to impose and hold onto its own version of reality. The call for immediacy further ensures that one's production of meaning does not function as another's frame through which to perceive and experience the social world. From here, one's performance or inscription of identity, for instance, ceases to be ensnared in power's categorization of bodies and the world by enunciating itself across and beyond existing normalized identitarian labels and their implied rituals of being. In this sense, Jesus's journey offers a sort of blueprint back toward what Spinoza had championed as Humanity as God. 


\section{Conclusion}

$\prod$ he texts explored in this volume emerge from different colonial in the reproduction of Empire. More importantly, they offer valuable and nuanced contestations to Empire and propose decolonial alternatives to imperial subjectivity, historicization, and knowledge.

While the experiences laid out in these literary products - and behind their creation - contribute to the study of Lusophone literatures, they also tackle larger questions beyond geo-linguistic categories of cultural production. The writers studied here offer robust new inquiries into Empire not only as a system of economic and political power, but also and especially as a field of meaning, economy of desire, and mode of epistemological domination. This does not mean that these works have little to offer to the study of Portuguese colonialism and its particular legacies. Rather, they offer approaches to that history through its interaction with, and contribution to, the larger field of Empire. At a historical moment when imperial categories of time, space, and bodies undergirding Empire continue to be reinforced, not least with the rise of right-wing white nationalism in Europe and the Americas, decolonial perspectives on intersubjective existence have become increasingly urgent. In this respect, each work or writer offers a different perspective and blueprint for deconstructing and moving beyond Empire.

Mário and Oswald de Andrade articulated and interrogated the Brazilian postcolony a hundred years after Brazilian political independence and roughly a hundred and fifteen years after the formal decolonization of Latin America. The moment was arguably propitious for a critical rereading of the imperial historicization of (post)colonial Brazil and a theorization of how to break with imperial signification and knowledge. As a long-time Timorese exile in Portugal during the final decades of Portugal's imperial project, Fernando Sylvan's poetry and political/cultural essays toe the line between anti-colonial discourse and a celebration of the state-backed narrative of Portugal as a transcontinental and multiracial nation. In doing so, Sylvan's 
work has lent poetic expression to the plight of East Timor against different imperial forces while also inserting such an anti-imperial struggle into transnational frameworks of decoloniality. Through his literary auvre, Luís Cardoso has furthered this transborder approach to decoloniality in the late twentieth and early twenty-first century while imagining, through his assortment of characters, decolonial significations of bodies and spaces.

Isabela Figueiredo and António Lobo Antunes, for their part, experienced Empire, and specifically Portuguese colonialism, through their complicity in it - the former as a young colonist in Mozambique and the latter as a conscript and medical doctor in the Portuguese armed forces during the colonial war in Angola. Their experiences, as well as those presented through Antunes's characters, serve a particular function in relation to dominant narratives of Portuguese colonialism and contemporary notions of Portuguese nationhood grounded in cultural syncretism and the erasing of colonial violence. Their political engagement with dominant Portuguese historical narratives offers, moreover, theoretical insights into how Empire historicizes its own power.

The poetry of Olinda Beja, meanwhile, reveals her own transnational experience and decolonial worldview as a São Toméan woman residing in Portugal and interpellated into European and Western signs of otherness at the intersection of race, sexuality, and gender. A tension sparked by residing within and questioning Empire while also forging a connection to her place of birth leads to a new mode of conceptualizing self and postcolony against the imperatives of Empire. In this vein, her poetry proposes a decolonial approach to identity as a scene of writing in constant flux, as an 'infinite shore' of borders and other sites of signification, toward the dismantling of imperial categories of time, space, and bodies.

Finally, Mário Lúcio Sousa's O Novissimo Testamento places this decolonial dismantling or 'delinking' at the core of the novel's plot, beginning with the traversal of the figure of Jesus Christ across imperial categories of race and gender. Although no complete undoing of the gender binary is present, this crossing of boundaries nonetheless gestures toward that possibility by targeting the rigidity of imperial masculinity and queering gender performance. In this regard, the novel is less about a particular experience within Empire and more about a fantastic questioning of categories that span race, ethnicity, gender, class, and (dis)ability.

The texts discussed here, particularly in their decolonial ethics, offer necessary rebuttals and alternatives to the ongoing rhetoric of Empire, in and beyond Lusophone contexts. This is an ethics that emerges in opposition to Empire's discursive field and the dominance over meaning contained therein. Speaking to the poststructuralist imagery contained in 
these works, they point toward a critical open-endedness, the proposal of possibilities rather than a structured model through which to cope with, combat, question, and/or reformulate both the signifying field governing intersubjective life and the terms by which subjects interact with and come to know others.

A recurrent theme in these literary projects is the conscious avoidance and critique of totality and totalitarian modes of existence; that is, of the One, or the established epistemic standards to which subjects must become aligned. In this sense, the battle against Empire must not follow the same roadmaps toward the construction of new notions of normativity, of pureness, of origin, and authenticity. In the trajectory these texts set toward decoloniality, no path is more authentic, or more decolonial, than another. In charting new modes of signification, the center is always already decentered, the phantasmatic value and priority of origin is quickly erased. In enunciating a signifying chain, be it through the trope of a journey or the beach of borders, the linking of signifiers always seems to imply its own delinking. This would be the critical aspect of a decolonial posture - anything linked should be read as delinkable, indeterminate, and incomplete.

Moreover, this sort of stance cursorily traces the contours of decolonial subjectivities beginning with a revision of interpellation, and interrogations of other imperial forces of subjectivation. In contrast, a decolonial subject, rather than being circuited to the central desire of Empire via particular modes of knowledge and historicization, is radically unhinged from such epistemological limits. The subject is not ensnared in a particular narrative of time, space, and bodies, but perpetually opened to Beja's infinity of borders. As such, the subject resists becoming a text within Empire translatable to the imperatives of power, as Sylvan and Cardoso's work demand.

The decolonial subject is ultimately one whose desire must be open to what Bhabha calls 'the enunciative boundaries of a range of other dissonant, even dissident histories and voices - women, the colonized, minority groups, the bearers of policed sexualities' (6). The subject will thus emerge as a scene of writing that produces meaning intersectionally in dialogue with other subject-positions - embodying, therefore, the trope of the border or boundary that 'becomes the place from which something begins its presencing in a movement not dissimilar to the ambulant, ambivalent articulation of the beyond' (Bhabha 7; emphasis original). In this spirit, the decolonial mission and trajectory laid out in these texts demand a persistent search beyond the limits of signification and its subsequently enacted violence. 


\section{Bibliography}

Abeysekara, Ananda. 'At the Limits of the Secular: History and Critique in Postcolonial Religious Studies.' The Oxford Handbook of Postcolonial Studies, edited by Graham Huggan. Oxford: Oxford University Press, 2013. Print.

Abraham, Nicolas, and Maria Torok. The Wolf Man's Magic Word: A Cryptonymy. Minneapolis: University of Minnesota Press, 1986. Print.

Ahmad, Aijaz. In Theory: Classes, Races, Literatures. London: Verso, 1992. Print.

Aidoo, Lamonte. Slavery Unseen: Sex, Power, and Violence in Brazilian History. Durham: Duke University Press, 2018. Print.

Almeida, Maria Cândida Ferreira de. Tornar-se outro: o topos canibal na literatura brasileira. São Paulo: Annablume, 2002. Print.

Althusser, Louis. Lenin and Philosophy and Other Essays. Translated by Ben Brewster. New York: Monthly Review Press, 1972. Print.

Anderson, Benedict. Imagined Communities: Reflections on the Spread and Origin of Nationalism. London: Verso, 1983. Print.

Andrade, Mário de. O Movimento Modernista. Rio de Janeiro: Casa do Estudante do Brasil, 1942. Print.

-. Macunaíma: O Herói sem Nenhum Caráter. São Paulo: Livraria Martins Editora. 1978. Print.

—. Macunaíma: O Herói sem Nenhum Caráter (Edição Crítica). Paris: ALLCA XX. 1988. Print.

Andrade, Oswald de. 'Manifesto Antropófago.' Revista de Antropofagia, vol. 1, no. 1, 1928, pp. 3-4. Print.

—. Obras Completas VI: Do Pau-Brasil à Antropofagia e às Utopias. Rio de Janeiro: Editora Civilização Brasileira, 1972. Print.

-. Estética e Política. São Paulo: Editora Globo, 1991. Print.

-. Pau Brasil. São Paulo: Editora Globo, 2003. Print.

Antunes, António Lobo. Os Cus de Judas. Lisboa: Dom Quixote, 1979. Print.

-. As Naus. Lisboa: Dom Quixote, 1986. Print.

—. O Esplendor de Portugal. Lisboa: Dom Quixote, 1997. Print.

Anzaldúa, Gloria. Borderlands/La Frontera: The New Mestiza. San Francisco: Spinsters/ Aunt Lute, 1987. Print.

Appiah, Kwame Anthony. 'Is the Post- in Postmodern the Post- in Postcolonial?' Critical Inquiry, vol. 17, no. 2, 1991, pp. 336-57. Print.

Aquino, Zilda Gaspar, and Ana Luísa Lotti. 'A argumentação nos manifestos: "Nhengaçu Verde Amarelo" e "Poesia Pau-Brasil."' Todas as Letras: Revista de Língua e Literatura, vol. 18, no. 1, 2016, pp. 128-40. Print. 
Araujo, Ana Lucia. Brazil through French Eyes: A Nineteenth-Century Artist in the Tropics. Albuquerque: University of New Mexico Press, 2015. Print.

Arendt, Hannah. The Human Condition. Chicago: University of Chicago Press, 2013. Print.

Beale, Frances. 'Double Jeopardy: To be Black and Female.' Sisterhood is Powerful: An Anthology of Writings from the Women's Liberation Movement, edited by Robin Morgan. New York: Random House, 1970.

Beja, Olinda. Aromas De Cajamanga e outras obras. São Paulo: Escrituras, 2009. Print.

Bender, Gerald. Angola under the Portuguese: The Myth and the Reality. Berkeley: University of California Press, 1978. Print.

Benjamin, Walter. The Origin of German Tragic Drama. Translated by John Osborne. London: Verso. 1977. Print.

Bethell, Leslie. Brazil: Empire and Republic, 1822-1930. Cambridge: Cambridge University Press, 1989. Print.

Bhabha, Homi K. The Location of Culture. New York: Routledge, 2004. Print.

Boehmer, Elleke. 'Stories of Women and Mothers: Gender and Nationalism in the Early Fiction of Flora Nwapa.' Motherlands: Black Women's Writing from Africa, the Caribbean and South Asia, edited by Susheila Nasta. New Brunswick: Rutgers University Press, 1992. Print.

Boris, Fausto. A Concise History of Brazil. Cambridge: Cambridge University Press, 1999. Print.

Bosi, Alfredo. História Concisa da Literatura Brasileira. São Paulo: Editora Cultrix, 1981. Print.

Braga, Paulo. A Ilha Dos Homens Nús. Lisboa: Editorial Cosmos, 1936. Print.

-. A Terra, a Gente e os Costumes de Timor. Lisbon: Editorial Cosmos, 1939. Print.

-. Timor 1930: País de Sonho e Encantamento. Dili: Crocodilo Azul, 2006. Print.

Brah, A, and Annie E. Coombes. Hybridity and its Discontents: Politics, Science, Culture. London: Routledge, 2000. Print.

Brennan, Timothy. 'Cosmopolitans and Celebrities.' Race \& Class, vol. 31, no. 1, 1989, pp. 1-19. Print.

Butler, Judith. Bodies that Matter: On the Discursive Limits of 'Sex.' New York: Routledge, 1993. Print.

-. 'Imitation and Gender Insubordination.' The Lesbian and Gay Studies Reader, edited by Henry Abelove, Michèle Aina Barale, and David M. Halperin. New York: Routledge, 1993. Print.

-. The Psychic Life of Power: Theories in Subjection. Stanford: Stanford University Press, 1997. Print.

-. Undoing Gender. New York: Routledge, 2004. Print.

Bylaardt, Cid Ottoni. 'O Pós-colonialismo Africano em Lobo Antunes.' Estudos Linguísticos e Literários, vol. 53, no. 1, 2016, pp. 5-19. Print.

Cabral, Amílcar. Revolution in Guinea: Selected Texts. New York: Monthly Review Press, 1970. Print.

Caminha, Pero V., J. F. A. Prado, Maria B. N. Silva, and Sílvio Castro. Pero Vaz De Caminha: Carta Do Achamento Do Brasil. Rio de Janeiro: AGIR, 1998. Print.

Campus, Haroldo de. 'Uma poética da radicalidade.' Oswald de Andrade: Obras Completas. São Paulo: Globo Livros, 2000. Print.

Cândido, Antonio. Formaçấo da Literatura Brasileira. Belo Horizonte: Editora Itataia Limitada, 2000. Print. 
Cardoso, Luís. Crónica De Uma Travessia: A Época Do Ai-Dik-Funam. Lisbon: Publicações Dom Quixote, 1997. Print.

-. Olhos de Coruja Olhos de Gato Bravo. Lisbon: Publicaçóes Dom Quixote, 2002. Print.

-. A Última Morte do Coronel Santiago. Lisbon: Publicações Dom Quixote, 2003. Print.

—. Requiem para o Navegador Solitário. Lisbon: Publicações Dom Quixote, 2007. Print.

Castelo, Claúdia. 'O Modo Português de Estar no Mundo:' O Luso-tropicalismo e a Ideologia Colonial Portuguesa (1933-1961). Oporto: Edições Afrontamento, 1998. Print.

- Passagens para África: O Povoamento de Angola e Moçambique com Naturais da Metrópole (1920-1974). Oporto: Ediçóes Afrontamento, 2007. Print.

Césaire, Aimé. Discourse on Colonialism. New York: Monthly Review Press, 1972. Print.

Chakrabarty, Dipesh. 'Postcoloniality and the Artifice of History: Who Speaks for 'Indian' Pasts?' A Subaltern Studies Reader: 1986-1995. Minneapolis: University of Minnesota Press, 1997. Print.

Chatterjee, Partha. Nationalist Thought and the Colonial World: A Derivative Discourse? Minneapolis: University of Minnesota Press, 1993.

-. Empire and Nation. New York: Columbia University Press, 2010. Print.

-. The Black Hole of Empire: History of a Global Practice of Power. Princeton: Princeton University Press, 2012. Print.

Chow, Rey. Writing Diaspora: Tactics of Intervention in Contemporary Cultural Studies. Bloomington: Indiana University Press, 1993. Print.

Cixous, Hélène, and Catherine Clement. The Newly Born Woman. Minneapolis: University of Minnesota Press, 1986. Print.

Coelho, Alexandra Prado. 'Isabela Figueiredo: "O colonialismo era o meu pai."” Público. 23 Dec. 2009. https://www.publico.pt/2009/12/23/culturaipsilon/noticia/ isabela-figueiredo-quoto-colonialismo-era-o-meu-paiquot-247765. Accessed 21 Feb. 2015.

Collins, Patricia Hill. Black Feminist Thought: Knowledge, Consciousness, and the Politics of Empowerment. New York: Routledge, 2000. Print.

Conrad, Joseph. Victory. London: Methuen Publishing, 2015. Print.

Copjec, Joan, editor. Radical Evil. New York: Verso, 1996. Print.

Costa, Luís Octávio. 'A selecção portuguesa já tem cognome e está prestes a ter um estilo: “Jogar bom futebol.”' Público, 6 Jun. 2010, http://www.publico.pt/desporto/ jornal/a-seleccao-portuguesa--ja-tem-cognome-e-esta-prestes-a-ter-um-estilojogar-bom-futebol-19557079. Accessed 2 Nov. 2015.

Costa, Oswaldo. 'Revisão Necessária.' Revista de Antropofagia, vol. 1, no. 1, 1928. Print.

Cowan, Bainard. 'Walter Benjamin's Theory of Allegory.' New German Critique, no. 22, 1981, pp 109-22. Print.

Crenshaw, Kimberlé W. 'Demarginalizing the Intersection of Race and Sex: A Black Feminist Critique of Antidiscrimination Doctrine, Feminist Theory and Antiracist Politics.' The University of Chicago Legal Forum, no. 139, 1989, pp. 139-67. Print.

Crippa, Clariane, and José Pires Laranjeira. 'Alda Espírito Santo: Negritudinista, pró feminina e descolonizada.' Academia.edu, https://www.academia. edu/30489087/ALDA_ESPÍRITO_SANTO_NEGRITUDINISTA_PRÓ-FEMININA_E_ DESCOLONIZADA. Accessed 8 Aug. 2017.

Cunha, Teresa. 'Imobilidades e fracturas. Mulheres, identidades e narrativas viajantes em Timor.' Revista Crítica de Ciências Sociais, no. 89, 2010, pp. 141-52. Print.

Dainotto, Roberto. Europe (in Theory). Durham: Duke University Press, 2007. Print. 
de Certeau, Michel. Heterologies: Discourse on the Other. Minneapolis: University of Minnesota Press, 1986. Print.

-. The Writing of History. New York: Columbia University Press, 1988. Print.

de Man, Paul. Blindness and Insight: Essays in the Rhetoric of Contemporary Criticism. Minneapolis: University of Minnesota Press, 1983. Print.

Derrida, Jacques. Writing and Difference. Translated by Alan Bass. Chicago: University of Chicago Press, 1978. Print.

-. 'Foreword.' The Wolf Man's Magic Word: A Cryptonymy, by Nicholas Abraham and Maria Torok. Minneapolis: University of Minnesota Press, 1986. Print.

-. Specters of Marx: The State of the Debt, the Work of Mourning and the New International. New York: Routledge, 2012. Print.

Dores, Raphael das. Apontamentos para um diccionário chorographico de Timor: memória. Lisbon: Imprensa Nacional, 1903. Print.

Doyle, Laura. 'Inter-Imperiality.' Interventions: Journal of Postcolonial Studies, vol. 16, no. 2, 2014, pp. 159-96. Print.

Du Bois, W. E. B. The Souls of Black Folk. New York: Vintage Books, 1990. Print.

Dussel, Enrique. Philosophy of Liberation. Maryknoll: Orbis Books, 1985. Print.

Edmonds, Alexander. Pretty Modern: Beauty, Sex, and Plastic Surgery in Brazil. Durham: Duke University Press, 2010. Print.

Elden, Stuart, and Eduardo Mendieta. Reading Kant's Geography. Albany: State University of New York Press, 2011. Print.

Esperança, João Paulo T. 'Um brevíssimo olhar sobre a literature de Timor.' Mealibra - Revista de Cultura, vol. 3, no. 16, 2005, pp. 131-34. Print.

Euripides. Medea. Santa Fe: El Cid Editor, 2003. Print.

The Examined Life. Directed by Astra Taylor, featuring Cornel West, Slavoj Žižek, Zeitgeist Films. 2009. Film.

Fanon, Frantz. The Wretched of the Earth. Translated by Richard Philcox. New York: Grove Press, 2004. Print.

-. Black Skin White Masks. Translated by Richard Philcox. New York: Grove Press, 2008. Print.

Fernandes, José Augusto. Timor. Impressóes e Aspectos. Oporto: Tipografia de 'A Tribuna,' 1923. Print.

Ferreira, Ana Paula. 'Home Bound: The Construct of Femininity in the Estado Novo.' Portuguese Studies, no. 12, 1996, pp. 133-44. Print.

—. 'Specificity without Exceptionalism: Toward a Critical Lusophone Postcoloniality.' Postcolonial Theory and Lusophone Literatures, edited by Paulo de Medeiros. Utrecht Portuguese Studies Series 1. Utrecht: Portuguese Studies Center, Universiteit Utrecht, 2007. pp. 21-40. Print.

Figueiredo, Isabela. Caderno de Memórias Coloniais. Coimbra: Angelus Novus, 2009. Print.

—. “Isto é a sério”: uma conversa com Isabela.' Caderno de Memórias Coloniais. Coimbra: Angelus Novus, 2009. Print.

Foucault, Michel. History of Sexuality, Vol. 2: The Use of Pleasure. New York: Random House, 1990. Print.

Franco, Jean. The Modern Culture of Latin America: Society and the Artist. Harmondsworth: Penguin, 1970. Print.

Freccero, Carla. 'Queer Spectrality: Haunting the Past.' A Companion to Lesbian, Gay, Bisexual, Transgender, and Queer Studies, edited by George E. Haggerty and Molly McGarry. Oxford: Blackwell Publishing, 2007, 194-214. Print. 
Freud, Sigmund. The Standard Edition of the Complete Psychological Works - Volume XX (1925-1926). London: Hogarth Press and the Institute of Psycho-Analysis, 1959. Print.

Freyre, Gilberto. O Mundo que o Português Criou: aspectos das relaçóes sociais e de cultura do Brasil com Portugal e as colônias portuguesas. Rio de Janeiro: José Olympio, 1940. Print.

-. New World in the Tropics: The Culture of Modern Brazil. New York: Knopf, 1959. Print.

-. The Portuguese and the Tropics. Lisbon: Executive Committee for the Commemoration of the Vth Centenary of the Death of Prince Henry the Navigator, 1961. Print.

-. The Masters and the Slaves. New York: Alfred A. Knopf, 1964. Print.

-. Casa-grande \& Senzala. Rio de Janeiro: Editora Record, 2002. Print.

- Aventura e Rotina: Sugestóes de uma Viagem à Procura das Constantes Portuguesas de Caráter e Ação. São Paulo: É Realizações Editora, 2010. Print.

- . O Luso e o Trópico: Sugestôes em Torno dos Métodos Portugueses de Integração de Povos Autóctones e de Culturas Diferentes da Europeia num Complexo Novo de Civilização: o Lusotropical. São Paulo: É Realizações Editora, 2010. Print.

Gabara, Esther. 'Facing Brazil: The Problem of Portraiture and a Modernist Sublime.' CR: The New Centennial Review, vol. 4, no. 2, 2004, pp. 33-76. Print.

Gândara, Paula. 'O esplendor de Portugal ou uma fragilíssima consciência do ser.' Portuguese Literary and Cultural Studies 19/20: Facts and Fictions of António Lobo Antunes, 2011, pp. 179-192. Print.

Gilman, Sander L. Difference and Pathology: Stereotypes of Sexuality, Race, and Madness. Ithaca: Cornell University Press, 1985. Print.

-. Freud, Race, and Gender. Princeton: Princeton University Press, 1993. Print.

Gilroy, Paul. The Black Atlantic: Modernity and Double Consciousness. Cambridge, MA: Harvard University Press, 1993. Print.

Glissant, Édouard. Caribbean Discourse: Selected Essays. Charlottesville: University Press of Virginia, 1989. Print.

Gomes, Heloísa Toller. 'A Questão Racial na Gestação da Antropofagia Oswaldiana.' Antropofagia Hoje? Oswald de Andrade em Cena, edited by Jorge Ruffinelli and João Cezar Castro Rocha. São Paulo: Realizações Editora, 2011, pp. 405-15.

Gordon, Avery. Ghostly Matters: Haunting and the Sociological Imagination. Minneapolis: University of Minnesota Press, 1997. Print.

Gould, Isabel A. Ferreira. 'Ficções do eu colonial e pós-imperial: memória, identidade e família em O esplendor de Portugal.' Portuguese Literary and Cultural Studies 19/20: Facts and Fictions of António Lobo Antunes, 2011, pp. 151-77. Print.

Gouveia, Saulo. Brazilian Modernism: The Metanarrative of Emancipation and Counter-Narratives. Chapel Hill: University of North Carolina Press, 2013. Print.

Gramsci, Antonio. Prison Notebooks. New York: Columbia University Press, 1992. Print.

Guattari, Felix. Chaosmosis: An Ethico-Aesthetic Paradigm. Bloomington: Indiana University Press, 1995. Print.

Guimarães, Antonio Sérgio Alfredo. 'Racism and Anti-Racism in Brazil: A Postmodern Perspective.' Racism and Anti-Racism in World Perspectives, edited by Benjamin Bowser. London: Sage, 1995, pp. 208-26. Print.

Guy, Peter. As Mirrors are Lonely: A Lacanian Reading on the Modern Irish Novel. Newcastle: Cambridge Scholars Publishing, 2014. Print.

Habermas, Jürgen. The Structural Transformation of the Public Sphere: An Inquiry into a Category of Bourgeois Society. Cambridge, MA: Massachusetts Institute of Technology Press, 1989. Print. 
Hall, Stuart. 'Minimal Selves.' Identity: The Real Me, edited by Homi K. Bhabha and Lisa Appignanesi. London: Institute of Contemporary Arts, 1987. Print.

-. 'Race, the Floating Signifier.' Directed by Sut Jhally. Written by Stuart Hall. Meeting Education Foundation. 1997. Film.

—. 'Cultural Identity and Diaspora.' Identity: Community, Culture, Difference, edited by Jonathan Rutherford. London: Lawrence \& Wishart, 1998, pp. 222-37. Print.

Haraway, Donna. 'A Cyborg Manifesto: Science, Technology and Socialist-Feminism in the Late Twentieth Century.' The Cybercultures Reader, edited by David Bell and Barbara M. Kennedy. London: Routledge, 2000, pp. 291-324. Print.

Hardt, Michael, and Antonio Negri. Empire. Cambridge, MA: Harvard University Press, 2000. Print.

Hartman, Saidiya. Scenes of Subjection: Terror, Slavery, and Self-Making in Nineteenth Century America. New York: Oxford University Press, 1997. Print.

Hicks, David. Rhetoric and the Decolonization and Recolonization of East Timor. London: Routledge, 2014. Print.

Irigaray, Luce. The Sex Which is not One. Ithaca: Cornell University Press, 1985. Print.

Jackson, K. David. 'Three Glad Races: Primitivism and Ethnicity in Brazilian Modernist Literature.' Modernism/modernity, vol. 1, no. 2, 1994, pp. 89-112. Print. Jameson, Fredric. 'Third-World Literature in the Era of Multinational Capitalism.' Social Text, no. 15, 1986, pp. 65-88. Print.

Jauregui, Carlos. 'Anthropophagy.' Dictionary of Latin American Cultural Studies. Tallahassee: University Press of Florida, 2012, pp. 22-28. Print.

Kant, Immanuel. Physische Geographie. Edited by Friedrich Theodor Rink. Königsberg: Göbbels and Unzer, 1802. Print.

-. Basic Writings of Kant. Edited by Allen W. Wood. New York: The Modern Library, 2001. Print.

-. Anthropology from a Pragmatic Point of View. Cambridge: Cambridge University Press, 2006. Print.

Klein, Herbert S. The Atlantic Slave Trade. Cambridge: Cambridge University Press, 1999. Print.

Lacan, Jacques. Écrits: A Selection. Translated by Alan Sheridan. New York: W. W. Norton \& Co., 1977. Print.

-. The Seminar, Book I: Freud's Papers on Technique, 1953-54. Translated by John Forrester. New York: W. W. Norton, 1988. Print.

-. The Seminar, Book II: The Ego in Freud's Theory and in the Technique of Psychoanalysis, 1954-55. Translated by Sylvana Tomaselli. New York: Norton; Cambridge: Cambridge University Press. 1988. Print.

-. Écrits: The First Complete Edition in English. Translated by Bruce Fink. New York: W. W. Norton, 2006. Print.

-. The Seminar, Book VII: The Ethics of Psychoanalysis, 1959-60. Translated by Dennis Porter. London: Routledge, 1992. Print.

Lima, Carlos Henrique Lucas. 'A Questão Transcontinental em Requiem para o Navegador Solitário.' Desenredos, no. 14, 2012, http://www.desenredos.com.br/ arquivo_129.html. Accessed January 20, 2017.

Lorde, Audre. 'Age, Race, Class, and Sex: Women Redefining Difference.' Sister Outsider: Essays and Speeches. Freedom: Crossing Press, 1984. Print.

Lourenço, Eduardo. O Labirinto da Saudade. Lisbon: Gradiva, 2000. Print. 
Luciano, Dana. Arranging Grief: Sacred Time and the Body in Nineteenth-Century America. New York: New York University Press, 2007. Print.

Lyotard, Jean-François. 'Answering the Question: What is Postmodernism?' Postmodernism: A Reader, edited by Thomas Docherty. New York: Columbia University Press. 1993. Print.

Maclachlan, Colin. A History of Modern Brazil: The Past against the Future. Wilmington: Rowman and Littlefield, 2003. Print.

Madureira, Luís. Cannibal Modernities: Postcoloniality and the Avant-Garde in Caribbean and Brazilian Literature. Charlottesville: University of Virginia Press, 2005. Print.

-. 'Is the Difference in Portuguese Postcolonialism the Difference in Lusophone Postcolonialism?' ellipsis, no. 6, 2008, pp. 135-41. Print.

-. 'Nation, Identity and Loss of Footing: Mia Couto's O Outro Pé da Sereia and the Question of Lusophone Postcolonialism.' Novel: A Forum on Fiction, vol. 41, no. 2, 2008, pp. 200-28. Print.

Maldonado-Torres, Nelson. 'On the Coloniality of Being.' Cultural Studies, vol. 21, no. 2, 2007, pp. 240-70. Print.

Martins, Adriana. 'Transgenerational Crises of Identity: Growing Up as Colonial Subjects in V. S. Naipaul's The Mimic Men and Luís Cardoso's The Crossing: A Story of East Timor.' Máthesis, no. 20, 2011, pp. 3-18. Print.

Martins, Ana Margarida Dias. 'The Whip of Love: Decolonising the Imposition of Authority in Paulina Chiziane's Niketche: Uma História de Poligamia.' The Journal of Pan African Studies, vol. 1, no. 3, 2006, pp. 69-85. Print.

Martins, Catarina. 'Recreating African Futures through Literary Imagination: The Newest Gender, Racial, and African Identities as Revealed in Mário Lúcio Sousa's O Novíssimo Testamento.' African Sociological Review, vol. 19, no. 1, 2015, pp. 34-42. Print.

Marx, Karl. Capital Volume I. Edited by Ernest Mandel, translated by Ben Fowkes. London: Penguin 1990. Print.

Mata, Inocência. A Suave Pátria: Reflexóes Politico-Culturais Sobre a Sociedade São-Tomense. Lisboa: Ediçóes Colibri, 2004. Print.

McMahon, Christina. 'Sozinha no Palco (Lusófono)? Circulation and Race Reflexivity in the Theatre of Mário Lúcio Sousa.' Luso-Brazilian Review, vol. 51, no. 2, 2014, pp. 80-104. Print.

Meade, Teresa. A Brief History of Brazil. New York: Checkmark Books, 2004. Print.

Medeiros, Paulo de. '(Re-)Constructing, (Re-)Membering Postcolonial Selves.' Stories and Portraits of the Self, edited by Helena Carvalhão Buescu and João Ferreira Duarte. Amsterdam: Editions Rodopi, 2007, pp. 37-49. Print.

Mignolo, Walter. Local Histories/Global Designs. Princeton: Princeton University Press, 2000. Print.

- . 'Coloniality of Power and Subalternity.' The Latin American Subaltern Studies Reader, edited by Ileana Rodriguez. Durham: Duke University Press, 2001. Print.

—. The Darker Side of Western Modernity: Global Futures, Decolonial Options. Durham: Duke University Press, 2011. Print.

-, and Tlostanova, Madina. Learning to Unlearn: Decolonial Reflections from Eurasia and the Americas. Columbus: Ohio State University Press, 2012. Print.

Morrison, Toni. Playing in the Dark: Whiteness and the Literary Imagination. New York: Vintage Books, 1992. Print. 
Moutinho, Isabel. 'The Fractured Affair of Timorese Ident/ities.' Portuguese Literary and Cultural Studies 17/18: Parts of Asia, 2010, pp. 357-71. Print.

Nairn, Tom. Faces of Nationalism: Janus Revisited. London: Verso, 1997. Print.

Nascimento, Evando. 'A Antropofagia em Questão.' Antropofagia Hoje? Oswald de Andrade em Cena, edited by Jorge Ruffinelli and João Cezar Castro Rocha. São Paulo: Realizaçōes Editora, 2011. Print.

N'Ganga, João Paulo. Preto no Branco: A Regra e a Excepção. Luanda: INALD - Instituto Nacional do Livro e do Disco, 1995. Print.

Nunes, Benedito. 'Antropofagia e vanguarda - acerca do canibalismo literário.' Literatura e Sociedade, no. 7, 2004, pp. 316-27. Print.

Nunes, Zita. Cannibal Democracy: Race and Representation in the Literature of the Americas. Minneapolis: University of Minnesota Press, 2008, Print.

Ortiz, Fernando. Contrapunteo cubano de tabaco y el azúcar. La Habana: Editorial de Ciencias Sociales, 1983. Print.

Owen, Hilary, and Anna Klobucka. Gender, Empire, and Postcolony: Luso-Afro-Brazilian Intersections. New York: Palgrave Macmillan, 2014. Print.

Parry, Benita. 'Overlapping Territories and Intertwined Histories: Edward Said's Postcolonial Cosmopolitanism.' Edward Said: A Critical Reader, edited by Michael Sprinker. Oxford: Blackwell, 1992, pp. 19-47. Print.

Pedrinha, Ponte. Andanças de Um Timorense. Lisbon: Colibri, 1998. Print.

Pimental, Joana. 'The Divided Mind: New Perspectives on Colonial Representations in Isabela Figueiredo's Caderno de Memórias Coloniais.' Romance Notes, vol. 53, no. 2, 2013, pp. 237-44. Print.

Pina-Cabral, João de. 'Lusotopia como Ecumene.' Revista Brasileira de Ciências Sociais, vol. 25, no. 74, 2010, pp. 5-20. Print.

Quijano, Anibal. Nacionalismo, neoimperialismo y militarismo en el Perú. Buenos Aires: Periferia, 1971. Print.

—. Imperialismo y 'marginalidad' en América Latina. La Paz: Mosca Azul, 1977. Print.

—. 'Colonialidad y modernidad/racionalidad.' Peru Indigena, vol. 13, no. 29, 1991, pp. 11-29. Print.

-. 'Colonialidad del poder, cultura y conocimiento en América Latina.' Anuario Mariateguiano, no. 9, 1997, pp. 113-21. Print.

- . 'Colonialidad del poder y clasificación social.' Journal of World-Systems Research, vol. 4, no. 2, 2000, pp. 342-86. Print.

-. 'Coloniality of Power, Eurocentrism, and Latin America.' Nepantla: Views from South, vol. 1, no. 3, 2000, pp. 533-80. Print.

Rama, Ángel. Transculturación Narrativa en América Latina. México, DF: Siglo XXI Editores, 1983. Print.

Rancière, Jacques. 'Ten Theses on Politics.' Theory and Event, vol. 5, no. 3, 2001, pp. 1-16. Print.

-. The Politics of Aesthetics: The Distribution of the Sensible. New York: Continuum, 2004. Print.

Renan, Ernest. The Life of Jesus. New York: The Modern Library, 1927. Print.

Retamar, Roberto Fernández. 'Nuestra América y Occidente.' Para el perfil definitivo del hombre. Havana: Editorial Letras Cubanas, 1974, pp. 222-50. Print.

Ribeiro, Grácio. Caiúru. Lisbon: Coleção ‘Amanhã,' 1939. Print.

Ribeiro, Joáo. Obras. Crítica. Os Modernos. Rio de Janeiro: Academia Brasileira de Letras, 1952. Print. 
Ribeiro, Margarida Calafate. 'Percursos Africanos: A Guerra Colonial na Literatura Pós-25 de Abril.' Portuguese Literary and Cultural Studies 1: Fronteiras/Borders, 1998, pp. 125-52. Print.

—. 'Mulheres portuguesas em Moçambique: outras memórias de Guerra Colonial.' Os Outros da Colonização: Ensaios sobre o colonialismo tardio em Moçambique, edited by Cláudia Castelo, Omar Ribeiro Thomaz, Sebastião Nascimento, Teresa Cruz e Silva. Lisbon: Imprensa de Ciências Sociais, 2012, 285-301. Print.

Rich, Adrienne. 'Compulsory Heterosexuality and Lesbian Existence.' Signs, vol. 5, no. 4, 1980, pp. 631-60. Print.

Ripley, William. The Races of Europe: A Sociological Study. New York: D. Appleton \& Co., 1899. Print.

Roque, Ricardo. 'The Unruly Island: Colonialism's Predicament in Late NineteenthCentury East Timor.' Portuguese Literary and Cultural Studies 17/18: Parts of Asia, 2010, 303-30. Print.

Rosenberg, Fernando. The Avant-Garde and Geopolitics in Latin America. Pittsburgh: University of Pittsburgh Press, 2006. Print.

Rothwell, Phillip. A Canon of Empty Fathers: Paternity in Portuguese Narrative. Lewisburg: Bucknell University Press, 2007. Print.

Rouanet, Sérgio. 'The Shandean Form: Laurence Sterne and Machado de Assis.' Portuguese Literary and Cultural Studies 13/14: The Author as Plagiarist - The Case of Machado de Assis, 2005, 81-103. Print.

Said, Edward W. Orientalism. New York: Vintage Books, 1979. Print.

—. 'Blind Imperial Arrogance.' Los Angeles Times. 20 Jul. 2003.

Salgado, Plínio, Paulo Menotti del Picchia, and Cassiano Ricardo. 'Nhengaçú Verde Amarelo Manifesto do Verde-Amarelismo ou da Escola da Anta).' Vanguarda Européia e Modernismo Brasileiro (Apresentação Crítica dos Principais Manifestos, Prefácios e Conferências Vanguardistas, de 1857 até hoje), edited by Gilberto Mendonça Teles. Petrópolis: Brazil: Editora Vozes, 1972, pp. 233-39.

Santiago, Silviano, and Ana L. Gazzola. The Space In-Between: Essays on Latin American Culture. Durham: Duke University Press, 2001. Print.

Santos, Boaventura de Sousa. 'Between Prospero and Caliban: Colonialism, Post-Colonialism and Inter-identity.' Luso-Brazilian Review, vol. 39, no. 2, 2002, pp. 9-43. Print.

-. Epistemologies of the South: Justice against Epistemicide. Boulder: Paradigm Publishers, 2014. Print.

Saussure, Ferdinand de. Course in General Linguistics. New York: McGraw-Hill Book Company, 1959. Print.

Schwartz, Jorge. 'Um Brasil em tom menor: Pau-Brasil e Antropofagia.' Revista de Critica Latinoamericana, vol. 24, no. 47, 1998, pp. 53-65. Print.

Schwarz, Roberto. Ao Vencedor As Batatas: Forma Literária E Processo Social Nos Inícios Do Romance Brasileiro. São Paulo: Duas Cidades/Editora 34, 2000. Print.

Seixo, Maria Alzira. Os Romances de António Lobo Antunes. Lisbon: Dom Quixote, 2002. Print.

Silva, Daniel F. Subjectivity and the Reproduction of Imperial Power: Empire's Individuals. New York: Routledge, 2015. Print.

Slemon, Stephen. 'Postcolonial Allegory and the Transformation of History.' Journal of Commonwealth Literature, vol. 23, no. 1, 2988, pp. 157-68. Print. 
Soares, Anthony. 'The Poets Fight Back: East Timorese Poetry as Counterdiscourse to Colonial and Postcolonial Identities.' Romance Studies, vol. 24, no. 2, 2006, pp. 133-47. Print.

- . 'National Identity and National Unity in Contemporary East-Timorese Literature.' Portuguese Studies, vol. 25, no. 1, 2009, pp. 80-101. Print.

Sousa, Mário L. O Novíssimo Testamento: Romance. Lisbon: D. Quixote, 2010. Print.

Sousa, Vinício de. Racismo, opressão dos povos. Lisbon: Editora Arcádia SARL, 1975. Print.

Spanos, William V. America's Shadow: An Anatomy of Empire. Minneapolis: University of Minnesota Press, 2000. Print.

Spiegel, Gabrielle. 'The Future of the Past: History, Memory, and the Ethical Imperatives of Writing History.' Journal of the Philosophy of History, no. 8, 2014, pp. 149-79. Print.

Spivak, Gayatri C. In Other Worlds: Essays in Cultural Politics. New York: Routledge, 1987. Print.

-. 'Can the Subaltern Speak?' Colonial Discourse and Postcolonial Theory: A Reader, edited by Patrick Williams and Laura Chrisman. New York: Routledge, 1993, pp. 66-111. Print.

—. A Critique of Postcolonial Reason. Cambridge, MA: Harvard University Press, 1999. Print.

Stam, Robert, and Ella Shohat. Race in Translation: Culture Wars around the Postcolonial Atlantic. New York: New York University Press, 2012. Print.

Stoler, Ann Laura. Carnal Knowledge and Imperial Power: Race and the Intimate in Colonial Rule. Berkeley: University of California Press, 2002. Print.

Sylvan, Fernando. 'Arte de Amar Portugal.' Ocidente: Revista Portuguesa Mensal, no. 59, 1960. Print.

-. Comunidade Pluri-Racial: Bases para uma Filosofia da Portugalidade, um Comportamento Social e Uma Orientação Política. Lisbon: Guimarães Editores, 1962. Print.

-. Racismo da Europa e a Paz no Mundo. Lisbon: Sociedade de Expansão Cultural, 1964. Print.

-. 7 Poemas de Timor. Lisbon: Livraria Portugal, 1965. Print.

—. Comunismo e Conceito de Nação em África. Lisbon: Editora Gráfica Portuguesa, 1967. Print.

—. Mensagem do Terceiro Mundo. Lisbon: Livraria Ler, 1972. Print.

—. Cantogrito Maubere: 7 Novos Poemas de Timor-Leste. Lisbon: Ler, 1981. Print.

Tamagnini, Isabel Pinto da França. Diário de uma Viagem a Timor (1882-1883). Lisbon: CEPESA, 2002. Print.

Tambling, Jeremy. Allegory. London: Routledge, 2010. Print.

Thomaz, Luís Filipe Ferreira Reis. A Nona do Pinto Brás (Novela Timorense). Lisbon: Fundação Dom Manuel II, 2010. Print.

Timor-Leste. Maputo: Instituto Nacional do Livro e do Disco, 1981. Print.

Toussaint-Samson, Adele. A Parisian in Brazil: The Travel Account of a Frenchwoman in Nineteenth-Century Rio de Janeiro. Wilmington: Scholarly Resources Inc., 2001. Print.

Vasconcelos, José. The Cosmic Race/La Raza Cósmica. Baltimore: Johns Hopkins University Press, 1979. Print.

Vieira, Patricia. Seeing Politics Otherwise: Vision in Latin American and Iberian Fiction. Toronto: University of Toronto Press, 2011. Print. 
- 'Specters of Colonial Violence: The Archive in António Lobo Antunes's South of Nowhere.' Portuguese Literary and Cultural Studies 19/20: Facts and Fictions of António Lobo Antunes, 2011, pp. 341-52. Print.

-. Portuguese Film 1930-1960: The Staging of the New State Regime. New York: Bloomsbury Press, 2013. Print.

-. 'Imperial Remains: Post-Colonialism in Portuguese Literature and Cinema.' Portuguese Journal of Social Science, vol. 14, no. 3, 2015, pp. 275-86. Print.

Vinkler, Beth Joan. 'The Anthropophagic Mother/Other: Appropriated Identities in Oswald de Andrade's 'Manifesto Antropófago.' Luso-Brazilian Review, vol. 34, no. 1, 1997, pp. 105-12. Print.

Wallace, Alfred Russell. The Malay Archipelago: the land of the orang-utan, and the bird of paradise. A narrative of travel with studies of man and nature. London: Macmillan, 1869. Print.

Wertheim, Albert. 'Euripedes in South Africa: Medea and Demea.' Comparative Drama, vol. 29, no. 3, 1995, pp. 334-47. Print.

Young, Robert J. C. Colonial Desire: Hybridity in Theory, Culture, and Race. London: Routledge, 1995. Print.

-. White Mythologies. London: Routledge, 2004. Print.

Žižek, Slavoj. The Sublime Object of Ideology. London: Verso, 1989. Print.

-. The Plague of Fantasies. London: Verso, 1991. Print.

-. The Metastases of Enjoyment: Six Essays on Women and Causality. London, Verso, 1994. Print.

-. Living in the End Times. London: Verso, 2011. Print.

Zurara, Gomes Eanes de. Chronica do Descobrimento e Conquista da Guiné. Paris: J. P. Aillaud, 1841. Print. 


\section{Index}

Abraham, Nicholas 29, 180, 188

adultery 273, 277-78

Africans

Lusophone African nations 173-74, 175,182

in Macunaíma 43, 46-47, 70, 72, 75

slave trade of $3,4,20,41,85$

Afro-Brazilianness 46, 47, 71, 97

allegorical movement, of Macunaima $70-75$

allegory

Antropofagia relating to 34

Benjamin on $48-49,51$

cannibal $25,49,50$

consumption, repetition, and 65-68

with 'Manifesto Antropófago' 35, 36,

$43,44,45,48,49,50,51,53$

against totality 47-54

Amadeu, in O Esplendor de Portugal 216-18, 220-22

America's Shadow (Spanos) 6

Amerindian 43, 46-47, 70, 72, 75, 101

Andanças de um Timorense ['Wanderings of a Timorese'] (Pedrinha) 145

Andrade, Mário de 24, 25, 86, 88, 287 anthropophagic period of 69 consumption and postcoloniality relating to $33-37,38,42,43,44$ plagiarism relating to $15,52-54$ see also Macunaíma

Andrade, Oswald de 24-25, 46, 194, 287

Anthropophagia and Macunaima relating to $69,71,77-78,82,89$, 104 consumption and postcoloniality relating to $33-37,43,47-54$

cuvre of 59

see also 'Manifesto Antropófago'; Pau Brasil

Angola under the Portuguese (Bender) 121

Anta 14, 98

anthropological works, in East Timor 108-11

Anthropology from a Pragmatic Point of View (Kant) 90

Anthropophagia and Macunaima,

Andrade, Oswald de relating to 69, $71,77-78,82,89,104$

anthropophagic logic, of cannibal

metaphor 35, 69

anthropophagic movement 46, 47, 69, 70, $83,92,95$

anthropophagic period, of Andrade,

Mário de 69

anthropophagic project 78, 87, 91, 93, 96

anthropophagic scene of consumption

25

café relating to 82-83, 95

'Carta prás Icamiabas' relating to $79-82$

coffee relating to $82-83$

commodities with $81-82$

decolonial scene of writing with 79 ,

$85,91,94,170-71$

elites relating to 82

anthropophagic scene of writing 87,89 ,

91, 92

anthropophagic voice $37,45,49,52$,

63-66, 68 
anthropophagic works $34,35,43,64$, 68

anthropophagy 14

anthropos 80-81

anticapitalist cultural movements 24

anti-colonial cultural movements 24 ,

89

'Anti-Herói' ['Anti-Hero'] 19-20

anti-imperial culture 5,8

anti-imperial political stances, movement of 87-89

Antropofagia 14, 15, 26, 101, 104

allegory relating to 34

bourgeois project of $34-40$

cannibal metaphor relating to 25 ,

$34-35,39,43,63,64,84,93,94$,

95, 98

counter-historicist project of 80

decolonial voice with $45,67,89$

discourse on 45,54

in Empire 33-37

failure and logocentrism with 86-89

History and 44-49, 53, 54

Jáuregui on 33

Kantian transcendental philosophy relating to 90-91

language associated with $87-88$

Macunaima in archive of $69-70$

movement of 71-77, 95

national identity reformulated with

$43-47,51,62$

primitivism with 38-39

Vargas on 34

see also 'Manifesto Antropófago'

Antropofagistas 37, 42, 43

Antunes, António Lobo 29, 173-74, 208, 209-32, 235, 288

auvre of 30, 209, 231

Anzaldúa, Gloria 251

Apontamentos para um diccionário

chorographico de Timor ['Notes for a

Chorographic Dictionary of Timor']

(das Dores) 107

archetypal foundational, in Pau Brasil 51,

$54,64,66,67$

Arendt, Hannah 186, 187, 190

Aromas de Cajamanga [Aromas of

Ambarella] (Beja) 31, 258, 260, 263
Aromas of Ambarella see Aromas de Cajamanga

Arouca, Manuel 174, 175-76

'Arte de Amar Portugal' (Sylvan) 117

Associação Social Democrática

Timorense [Timorese Social

Democratic Association] 128

'The Ballot or the Bullet' (Malcom X)

124

being-for-Empire 224

Beja, Olinda 30

on borders 258-63, 289

œuvre of 31, 237, 245, 260

poetry of $31,251-58,260-61,263$,

288

rainbow imagery of 261

sign-system of 262,263

see also 'Visão'

Bender, Gerald 121

Benjamin, Walter 48-49, 51

Bhabba, Homi K. 34-35, 51-53, 66-68, $78,136,142,289$

on hybridity 247-49, 247n2, 251

Biard, François-Auguste 41, 42

big Other 84, 159-60, 164, 166, 235, 254, 272

The Black Atlantic (Gilroy) 144

Black Brazilian Front see Frente Negra

Brasileira

black natives 191

blackness 46-47, 62, 97, 104, 274

crime of 193

imperial articulation of 242

in 'Visão' 240-50

Black Skin, White Masks (Fanon) 11, 242-43

'The Blacks of Pousaflores' see Os Pretos de Pousaflores

black women 178-80, 183, 221, 240, 246-47

see also Jesus, as black elderly woman

Boaventura, Maria Eugenia 73-74

Bodies That Matter (Butler) 284

'body-institution,' of Sylvan 118

Bopp, Raul 71, 99, 101

Bô Tendê? ['Do you Understand?'] (Beja)

$31,237-45,263$ 
bourgeois 82, 85, 220

of Antropofagia project $34-40$

European 37, 39-40

Braga, Paulo 108-09, 112-13

Brah, Avtar 248

Brazil

colonial and postcolonial history of $34-36,38,70,72,76,99,287$ as colony and nation-state 4 global economic power of 4 independence of 33

industrialization in 4,14

inequities in 85

languages of 33

metropolitan city life of 42

nation-sign of $4,43-44,46,62,62 \mathrm{n} 1$,

$87,92,98,101,104,105$

Portuguese colonialism of 1,4

primitivism relating to 39

slavery in 4

see also Pau Brasil

Brazilian-Brazil 43, 71, 80, 94, 97

Brazilian identity 75

Brazilian Integralism see Integralismo

Brazilian modernism 88, 104

Brazilian Modernismo 97

Brazilian Natives 41

Brazilianness

Empire and 68

multiracial vision of 95-96, 102-04

Brazilian Western historicization 55

'Brazilwood' see Pau Brasil

Butler, Judith 283-84

Caderno de Memórias Coloniais

(Figueiredo) 28-29, 173, 174-75, 208, 218

café $82-83,95$

Caiúru (Ribeiro) 111

Caminha, Pero Vaz de 2, 23, 179

Camões, Luís Vaz de 132

Cândido, Antônio 35, 36

cannibal allegory $25,49,50$

cannibal genealogy 78, 94

'Cannibal Manifesto' see 'Manifesto

Antropófago'

cannibal metaphor, Antropofagia

relating to $39,43,64,94,95,98$ anthropophagic logic of 35, 69

meanings of $63,84,93$

movement of 25,34

A Canon of Empty Fathers (Rothwell) 181

'Can the Subaltern Speak?' (Spivak) 271-72

Cantogrito Maubere (Sylvan) 142-43

capitalism 78

global $8,14,89$

late $2,3,9,11,13,23,106$

slave-based 2, 4

Cardoso, Dulce Mario 174

Cardoso, Luís 27-28, 289

background of 145-46

Empire relating to $145,148,149$

historicization in $145,148,149$

cuvre of 27, 147, 148, 288

Olhos de Coruja Olhos de Gato Bravo by 148

Tetun-Prasa spoken by 145-46

A Última Morte do Coronel Santiago by 148

untranslatable subalternity with 145

see also Requiem para o Navegador Solitário

Carlos

in O Esplendor de Portugal 210-18, 221-25, 227-28, 230, 232, 235

spectral, specular and 221-25

Carta do Achamento do Brasil [Letter on the Discovery of Brazil] (Caminha) 2, 179

'Carta prás Icamiabas' ['Letter to the Icamiabas'] 79-82, 87, 89, 94

Cartesian dictum of Reason 135

Casa Grande e Senzala [The Masters and the Slaves] (Freyre) 59, 72, 102, 103

Catarina

as commodity $157-58,163$

Empire ensnarement of 149-56, 158

enjoyment explored by 160

Gerbault and 167-68

historicization of 152-60

inter-imperial desires of 152

Mati Hari and 169-70

Monteiro and 149-58, 162, 163, 171

as nona 155

Pereira and 156-63, 165

Prince Charming and 154-55 
rape of $28,149,154,155,171$

Requiem para o Navegador Solitário

narrated by $149-56,167-72$

Semedo and 168-69

cemetery 228-31

centerless scene of writing 135

centrality 142

fantasies of 134

metropolitan 16

phantasmatic 126, 127, 134

Chow, Rey 248

Christianity 267

Chronica do Descobrimento e Conquista da

Guiné [Chronicle of the Discovery and

Conquest of Guinea] (Zurara) 2

cisgendered white women 178, 191

'civilização-padrão' 123-24

Clarisse, in O Esplendor de Portugal 210,

211, 214, 217

Cobra Norato (Bopp) 71, 99

coffee consumption 82-83

collective identities 137

colonial and postcolonial history, of

Brazil 34-36, 38, 70, 72, 76, 99, 287

colonial desire 178

Colonial Desire (Young) 247-48

colonial discourse 47, 75, 121, 191,

206-10

cultural, on Antropofagia 45, 54

on otherness $10,14,79,90,97,102$,

$139,173,189$

of race 223,247

on whiteness 212,213

colonial expansion, European 6, 11

colonial field, of meaning 179, 202, 213,

$217,222-25,228$

colonial gatherings, in 0 Esplendor de

Portugal 224-25

colonial historicization, in East Timor

111

colonialism 10, 181, 183, 209

European $39-40$

experience of 69

father as 181,185

patriarchies with 5, 85-86, 201

of Portugal 1, 4

racial signifiers of 213,249

Sylvan on $125,127,136$ coloniality 36

definition of 10

global 72

of power $3-4,8-9,10,72,213,221$

coloniality/decoloniality theoretical

paradigm 10

'Coloniality of Power and Subalternity'

(Mignolo) 9

colonial map, of Portugal 16

colonial New World 51

colonial occupation, late capitalism from

9

colonial past experience, of Figueiredo

180-82

colonial presence, Portuguese, in East

Timor 107-15, 287

colonial spaces, spectrality and ruins of 227-31, 232

colonial violence 182, 186, 191, 205

colonial whiteness 199

colonial white womanhood

body of 196,198

ensnarement of 197

Estado Novo relating to $197-98$

father and 196-203

paternalism with 196

role of 197-98

colonization 5,20

colony and nation-state, of Brazil 4

commodities 81-82

Catarina as $157-58,163$

consumption of 161

common experiences, of subalternity

$138,143-44$

Communidade Pluri-Racial ['Pluri-Racial

Community'] (Sylvan) 27, 116-28

communism, Sylvan on 125-26

Comunismo e Conceito de Nação em África

['Communism and the Concept of

Nation in Africa'] (Sylvan) 124, 125n3

conceptualizations 90-91

dominant 136

of Empire 3, 6, 10-11

of imperialism 6

Conrad, Joseph 109-10, 115, 131-32

consumption

dominant 82

imperial 74 
with otherness $16,25,40-41,45$

of primitive $37-42$

rearranging of $42-47$

repetition, allegory, and 65-68

scene of 75-76

see also anthropophagic scene of

consumption

consumption and postcoloniality,

decolonizing of

Andrade, Mário de, relating to 33-37,

$38,42,43,44$

Andrade, Oswald de, relating to

33-37, 43, 47-54

Antropofagia in Empire 33-37

Pau Brasil 54-65

Coombes, Annie 248

'Corporal Form' see 'Forma Corporal'

cosmopolitanism 39, 42

Crenshaw, Kimberlé Williams 245-46, 251

crime, of blackness 193

Crónica de Uma Travessia - A Época do

Ai-Dik-Funam [The Crossing] (Cardosa)

146-47, 148

cryptology see imperial cryptology

crypts $194,233-36$

cemetery and 228-29

colonial past and $180-82$

Figueiredo relating to $188-90,191$

of historicization 182-85, 188-90

sepulchral function of 189

cultural commonality, phantasmatic 16

cultural discourse, on Antropofagia 45,

54

cultural movements

anticapitalist 24

anti-colonial 24, 89

of anti-imperial political stances

$87-89$

culture 42

anti-imperial 5, 8

democratization of 78-79

of East Timor 109

identity of 136-37, 174

Lusophone studies of 17

monoculturalism 15

multiculturalism 95

postcoloniality critique of 47 see also multicultural ethics, decolonial meta-identity and; transculturation renegotiation

Os Cus de Judas [South of Nowhere]

(Antunes) 30, 208, 209, 236

'A Cyborg Manifesto' (Haraway) 285-86

Darker Side of Modernity and Learning to Unlearn (Mignolo and Tlostanova) 13, 231

'Darkness' see 'Escuridão'

das Dores, Raphael 107-08

decolonial delinking, decrepit narratives and 232-35

decolonial identity 133

decoloniality 10, 15, 17, 289

Mignolo on 8, 12-13, 135, 234-35

of postnationalism 21-24

decolonial meta-identity see

multicultural ethics, decolonial

meta-identity and

decolonial narrative device for colonial

experience, spectrality as 208-10,

221-36

decolonial nationalism 253

decolonial non-imperial modernization 80

decolonial politics 6-16

decolonial potential, of Pau Brasil 63

decolonial scene of writing $79,85,91$,

$94,170-71$

decolonial sign-system, mapping of 257-63

decolonial studies 5, 8, 9, 11, 13, 14, 34

decolonial subjectivity 67

decolonial voice, with Antropofagia 45, 67,89

decolonization 7, 8, 145

of intercultural meaning 27

of Latin America 287

of Lusophone 16-21

decolonizing hybridity, through

intersectionality and diaspora 237-44

conclusion to 263

decolonial sign-system, mapping of 257-63

double-consciousness from

intersection 251-57 
subjectivation, intersectionality of 245-50

decolonizing pluri-racial nation, Sylvan on $116-28$

deculturation 76

Deixei o Meu Coração em África ['I Left My Heart in Africa'] (Arouca) 174, $175-76$

'Demarginalizing the Intersection of Race and Sex' (Crenshaw) 245

democracy, racial 18, 72, 100, 102, 102n1, 103-04

democratization, of culture 78-79

Derrida, Jacques 78, 134, 189, 207, 208, 235-36, 265

writings of $11,27,29,78,134,185$, $188,203,284$

desire $152,178,287$

of Empire 101, 162, 254

of Figueiredo 182, 200

of heterosexual male $246-47$

of Other 84, 93, 160, 161-62, 165-66, 167

de Sousa Santos, Boaventura 13-14, 16, 20, 111

dialogic epistemes 268-72, 273, 276, 281 Diário de uma Viagem a Timor ['Journal of a Journey to Timor'] (Tamagnini) 113 Dias Martins, Ann Margarida 260 Dili, in East Timor 106-07, 110, 112-13, $149,150,155-56$

discourse see colonial discourse; cultural discourse, on Antropofagia

'Discoveries' 121-22, 131, 207

discrimination 245-46

dominant conceptualizations 136

dominant consumption 82

Domingas, Figueiredo relationship with 204-05

double-consciousness 242-43, 251-57

'Do you Understand?' see Bô Tendê?

Du Bois, W. E. B. 242, 243, 257-58

'Earth' see 'Terra'

East Timor 3, 20, 21, 22-23, 27-28

das Dores on 107-08

Dili in 106-07, 110, 112-13, 149, 150, $155-56$ identity of 147

independence of 115-16

Indonesian occupation of 145

literature of 106

as location of Requiem para o Navegador

Solitário 149-56

multiethnic population of 106

nonas in $112-13,155$

Portuguese decolonization of 145

25-year occupation of 116

see also imperial inscriptions, of colony and bodies, in East Timor

economy

of Brazil 4

in Pau Brasil 56, 57-58, 61

ego-ideal 84, 164, 201, 205-06, 272

superego $160-67$

elites, of São Paulo 73, 77, 78, 82-83, 86

Empire 1, 130, 130n 5

Antropofagia in $33-37$

approach to $4,6-7$

Brazilianness and 68

capitalism, patriarchy, and, in 'Manifesto Antropófago' 78

Cardoso, Luis, on 145, 148, 149

Catarina ensnared by $149-56,158$

challenging of 11-12

conceptualization of 3, 6, 10-11

consuming of 54-65

desire of 101, 162, 254

excess of 172

experiences of $15-16,18,69$

field of $162,168,264$

framework for 7,8

gaze and surveillance of 133

globality of 138

ideology of 4,7

intersectionality relating to 5

literary work relating to $6-7,21$

loss of $187-88$

patriarchies in 181

philosophical foundations of 15

postcoloniality, decolonial politics, and 6-16

postnation against 135-43

Reason and 89-91

reproduction of $132,160,218,223$,

$243,245-46,287$ 
signifying chain of $5,34,44-45,47$, $138,143,188,190,212-13,229$, 231-32, 257

taxonomies relating to $4-5,45,85$, 237, 272

textuality of 164

theorization of 36

Empire psychic links, reversing of 83-86

Empire's masculine subject, interpellation and 167-70

endemoninhados 270

enjoyment 160-67

Enlightenment 10, 36

ensnarement, of colonial white womanhood 197

epistemes, dialogic 268-72, 273, 276, 281

epistemologies 10, 12, 40,87, 89, 134, 258

Eurocentric 8, 13

of South 14

'Escuridão' ['Darkness'] (Beja) 260-61

O Esplendor de Portugal [The Splendor of

Portugal] (Antunes) 29-30, 173-74

Amadeu in 216-18, 220-22

Carlos in 210-18, 221-25, 227-28, 230, 232, 235

Clarisse in 210, 211, 214, 217

colonial gatherings in 224-25

immobilization relating to $214^{-15}$

Isilda in 209-11, 214-15, 218-20, 221-32

Lena in 211-13

narrative of 209-14

Rui in $210,211,214$

spectral composition of 211-21

Estado Novo 34, 96-97, 102, 117, 121,

132

colonial white womanhood relating to $197-98$

fall of 173

imperial inscriptions relating to 107 , 107n $1,114,183$

Sylvan on 114,126

ethnic makeup, of East Timor 106, 107, 114-15

ethnic/racial otherness $6,46,80,91,100$, 102,240 ethnographic works, in East Timor 108-11

Eurocentric epistemologies 8, 13

European bourgeois 37, 39-40

European colonial expansion 6, 11

European cultural forms 42

Europeanization 238-39

European modernisms 88

European national imperial projects 1

European primitivism 39

Europeans, Amerindians, Africans, in

Macunaima 43, 46-47, 70, 72, 75

European supremacy $123-24$

exploitation $48,50,63,82-83,121,183$

Fanon, Frantz 11, 27, 138, 141, 242-53

fantasies

of centrality 134

of otherness $75,91,122,160,166$, $169,171,242$

of racial and sexual otherness

178-79, 220

of whiteness 189, 246

father

apparition of 195

as colonialism 181,185

colonial white womanhood and

196-203

contradictions of 183

displacement of 204-05

of Figueiredo 178-80, 184-85, 189, 190-96, 199, 201-07, 220

ideology and 178-80

Name-of-the-Father 178, 192

paternal function/enforcer of 181-82

privileges of 178

sexual liaisons of 196-97

sins of 206-07

specter of $205^{-07}$

symbolic function of 178

'fazenda antiga' (Andrade, Oswald de)

194

female sexuality 199, 201

Ferreira, Filipe 113

field, of meanings $228,254,287$

colonial 179, 202, 213, 217, 222-25, 228

of Empire 162, 168, 264 
imperial 10, 46, 64, 79, 83-84, 85, 89, 90, 93, 95, 101, 111, 113, 122, 124, $134,154,160,162,164,165,170$,

184, 200, 201, 202, 206, 223, 224, $227,229,235,281$

of power 161

Figueiredo, Isabela 28-29, 173, 208, 218, 288

background of $174-75$

body of 178,180

colonial past experience of $180-82$

crypts relating to $188-90,191$

desire of 152,200

Domingas relationship with 204-05

father and 178-80, 184-85, 189,

190-96, 199, 201-07, 220

interpellation of 179

memoir of 176-80, 183-88, 191-92, 199, 206-07

preadolescent episodes of 199-200, 204-05

sexuality of $177,178-80,182$, 196-203, 204-05

as white woman 178

'The Final Death of Colonel Santiago' see A Última Morte do Coronel Santiago

fin-de-siècle 34, 39, 61

Formacão da Literatura Brasileira

['Formation of Brazilian Literature'] (Cândido) 35

'Forma Corporal' ['Corporal Form'] (Beja) 255-57

Frente Negra Brasileira [Black Brazilian

Front] 97

Freud, Sigmund 63, 161, 162, 166, 273-74

Freyre, Gilberto 59, 63, 72, 100, 102, 103-04, 114-15

gender

class, sexuality, disability, race, and 264-65, 288

masculinity undone and categories of 279-86

see also transgendering, of Jesus

gendered power 280

gendered subjectivation 285

gender insubordination 283-84

genealogy 63, 78, 94
Geography (Kant) 90-91

geopolitics, of knowing and knowledge $80-81$

Gerbault, Alain 167-68

Gilroy, Paul 144

global capitalism 8, 14, 89

global coloniality 72

global dependency 37

globality, of Empire 138

global North 235

global practice, of power 7

global subaltern movement 19

gnosis 251, 258

Gomes, Aida 174

Great Depression 95

Hall, Stuart 137, 138, 248

Hallucinated City see Paulicéia Desvairada Haraway, Donna 285-86

Heart of Darkness (Conrad) 131-32

hegemonic historicity 233

hegemony 6, 11-12, 44, 77, 89-90, 94, 104

heteronormative masculinity 161,163 , $166,169,195$

heterosexual male desire $246-47$

historical narrativization 49,68

historical primitive 38

historicity, hegemonic 233

historicization $13,16,25,27,35,55$

of Catarina $152-60$

crypts of $182-85,188-90$

in East Timor 111

of events, in 'Visão' 242

imperial 164, 184, 246, 286, 287

intersectional 170-71

whiteness and 73

in writings of Cardoso, Luis 145, 148, 149

history

of Brazil 34-36, 38, 70, 72, 76, 99, 287

of East Timor 106

of Portuguese imperialism 3

of West 68

History 209, 234

Antropofagia and 44-49, 53, 54

imperial 73

machine of 71 
path of 91

subaltern and 73

homosexual masculinity 164

humanitas $81,122,123$

humanity, Portuguese imperialism impact on 2

hybridity 78, 247-49, 247n2, 251

see also decolonizing hybridity, through intersectionality and diaspora

Hybridity and its Discontents (Brah and Coombes) 248

Icamiabas 79

'Identidade' (Beja) 251, 253-54, 256, 260 identity

of East Timor 147

identitarian framework 17, 40, 111,

$119,127,171,220,221,227,229$,

249

metaphoric journey of 133

unfixed 128-35

see also meta-identity; specific identity

ideology 54

of Empire 4, 7

father and 178-80

of rule 49

'I left My Heart of Africa' see Deixei o Meu

Coração em África

A Ilha dos Homens Nus ['The Island of

Naked Men'] (Braga) 109

imago 241, 246

immobilization 214-15

imperial articulation, of blackness 242

imperial categories, of race 71

imperial consumption 74

imperial cryptonomy 29, 174-77

conclusion to 207

crypts, colonial past and 180-82

father, ideology and 178-80

framework for $188-90$

with Lusophone African nations 173

omniscience, of paternal specter 191-96

Portugal contemporary imperial narrative, crypts of historicization and $182-85$

specter persistence $205^{-07}$ spectrality, imperial public sphere and 185-88, 185n3, 189, 195, 201-03

imperial exploitation and imperial discourses, of racial difference 121 imperial field of meaning see field, of meanings

imperial historicization 164, 184, 246, 286, 287

imperial History 73

imperial inscriptions, of colony and

bodies, in East Timor 164

access to 112

of anthropological and ethnographic works 108-11

of colonial historicization 111

of cultural life 109

Estado Novo 107, 107n1, 114, 183

ethnic makeup 107, 114-15

Indonesia relating to 116,127

influence of 111

linguistic makeup 108, 113-14

occupations relating to 107

Portuguese colonial presence 107-15, 287

of Portuguese orientalist fiction 111

of travelers 107-09

United States relating to 116

imperialism 136

conceptualization of 6

contours of 1

impact of 5

subalternity with $3,4,5,20,132$

Western 1, 3, 6, 7, 10, 44, 50

see also Portuguese imperialism

imperial language 23

imperial masculinity 218

imperial narrative 50, 67

see also Portugal, contemporary

imperial narrative of

imperial power 1, 40, 225

imperial public sphere, spectrality and

185-88, 185n3, 189, 195, 201-03

imperial subalternity, of Portugal 16

independence

of Brazil 33

of East Timor 115-16

indigeneity $14-15,45,74,76$ 
Indonesia, East Timor relating to 116, 127,145

industrial city, of São Paulo 62, 82-83, 85

industrialization

in Brazil 4, 14

Portuguese imperialism impact on 2 industrial modernity 81

inscriptions

of jouissance 156-60

postcolonial 147

see also imperial inscriptions, of

colony and bodies, in East Timor

Integralismo [Brazilian Integralism] 97

intercultural meaning, decolonization of 27

inter-imperiality $3,5,152$

interknowledge 15

internationalism, revolutionary 5

International Year for Action to Combat

Racism and Racial Prejudice 135

interpellation 118, 206, 219, 235

of Figueiredo 179

interruption of 89-94

with Macunaima 84

masculinity and 167-70

in 'Visão' 240

interracial sex 181, 182, 199, 220-21,

244,247

intersection, double-consciousness from 251-57

intersectional historicization $170-71$

intersectionality $5,18,31,138,138 \mathrm{n} 6$,

254

of imperial exploitation and imperial

discourses, of racial difference 121

of subjectivation $245-50$

in 'Visão' 246, 249-50

see also decolonizing hybridity,

through intersectionality and

diaspora

intersubjective life, of Jesus 276-77,

279

'In the Country of Tchiloli' see No País do Tchiloli

Isilda

cemetery and 228-31 death of 225-27, 232

in O Esplendor de Portugal 209-11,

214-15, 218-20, 221-32

spectral and specular relating to

221-27

vanishing of 230-31

'The Island of Naked Men' see A Ilha dos Homens Nus

Jameson, Fredric 33, 37

Jáuregui, Carlos A. 33

Jesus

dialogic epistemes of $268-72,273$,

276, 281

ego-ideal and 272

reincarnation of 31-32, 266-68, 273,

$275,280,286$

transgendering of 264-67, 280-81, 288

Jesus, as black elderly woman 268

adultery relating to $273,277-78$

endemoninhados and 270

exile of $274-75$

intersubjective life of 276-77, 279

masculinity, dark continent and decentering of $273-78$

masculinity undone, gender

categories and 279-86

multitude and 269-70, 276

reading of 282

'Sermon on the Mount' of 273, 275, 277

signification and 274, 285

in tavern 281-83, 284

Third Age of 269-70

jouissance

Lacanian theory of 28, 140-41, $141 \mathrm{n} 7,160-61,162,164,166,167$, 168-69

writing, resistance, and inscription of $156-60$

'Journal of a Journey to Timor' see Diário de uma Viagem a Timor

Journal of Portuguese Language 52

journey

of Macunaíma 70-71, 83-86

metaphoric, of identity 133

to São Paulo 26, 79 
Kant, Immanuel 90-91

Kantian races 99

knowledge 10 geopolitics of knowing and 80-81 modes of $4,7,9,11,12,13,15,16$ sites of $8,14,15$ subject of knowledge and 84

Lacan, Jacques 137, 180, 195, 201, 226, 272, 277

father role relating to 178,192

Lacanian theory

of jouissance $28,140-41,141 \mathrm{n} 7$, $160-61,162,164,166,167,168-69$ of other $30,54,84,235,246$ languages

Antropofagia associated with 87-88 of Brazilian nationhood 33

of colloquial Portuguese 54 imperial 23

Marxian 82 Modern European 87 of Portugal 16, 18, 22-23, 87, 128

'The Last Year in Luanda' see 0 Último Ano em Luanda

late capitalism 2, 3, 9, 11, 13, 23, 106

Latin America 9, 10, 14, 287

The Latin American Subaltern Studies Reader 9

Law, Requiem para o Navegador Solitário associated with 161-62, 163, 164-67, $168,171-72$

laws, of whiteness 181

Lena, in O Esplendor de Portugal 211-13

letter, of Macunaíma 26, 53, 79, 86-87, 93-94, 105

Letter on the Discovery of Brazil see Carta do Achamento do Brasil

'Letter to the Icamiabas see 'Carta prás Icamiabas'

The Life and Opinions of Tristram Shandy, Gentleman and Machado de Assis's Posthumous Memoirs of Brás Cubas (Sterne) 214

Life of Jesus (Renan) 266-67

linguistic makeup, of East Timor 108, 113-14

literacy 128 literature

of East Timor 106

Lusophone 3, 16, 17, 106, 116-17, 246, 287-88

Portuguese 21-24

postcolonial 23-24, 27, 33, 40, 248

Local Histories/Global Designs (Mignolo)

8,13

logocentrism, Antropofagia failure and 86-89

Lopes, Fernão 2

López, Kimberle 38, 39, 47, 74

Os Lusíadas [The Lusiads] (Camóes) 132

O Luso e o Trópico [The Luso and the

Tropical] (Freyre) 114-15

Lusofonia 3, 3n1, 5, 16, 18, 23

Lusophone

cultural studies 17

decolonizing of 16-21

inter-imperial 5

literatures relating to $3,16,17,106$, $116-17,246,287-88$

postcolonialism 18, 20-21, 176

Lusophone African nations formal colonization end with 173 imperial cryptology with 173 political reconstruction of 173 retornados with 173-74, 175, 182

Lusotopia 16

Lusotropicalism 114, 115, 120 claims of $182-83$

narratives relating to $117,119,121$, $171,175-76,181,183,184$ racial democracy and 18,100

\section{Macunaíma}

journey of $70-71,83-86$

letter of 26, 53, 79, 86-87, 93-94, 105

nationalism of $74-75$

significational gaze of $70-71,84$

Macunaima ['Macunaíma'] (Andrade,

Mário de) 25-26, 48, 101, 105

allegorical movement relating to 70-75

anthropophagic scene of consumption 79-84, 85, 94, 95

within Antropofagia archive 69-70 cannibal genealogy in 78, 94 
ego-ideal 84, 164

Europeans, Amerindians, Africans

relating to $43,46-47,70,72,75$

interpellation with 84

as multiracial $70-71,73$

plagiarism relating to $15,52-54$

spaces of production, subalternity,

privilege of urban terrain 83

spatial movement 71

transculturation renegotiation

relating to $75^{-79}$

whiteness in $72-73$

see also Anthropophagia and

Macunaima, Andrade, Oswald de

relating to

Madureira, Luís 3, 18, 20-21, 44, 99-100, 111

Magalhães, Jaime 174

Malcom X 124, 138

Malisera, in Requiem para o Navegador

Solitário 151, 152, 153, 156

'Manifesto Antropófago' ['Cannibal

Manifesto'] (Andrade, Oswald de) 25,

$55,67,72,77$

Afro-Brazilianness and 46, 47, 71, 97

allegory associated with $35,36,43$,

$44,45,48,49,50,51,53$

Empire, capitalism, patriarchy 78

'Manifesto da Poesia Pau-Brasil' see Pau Brasil

marginalization, with Portuguese colonialism 21

Martim Cererê (Ricardo) 71

Marx, Karl 254

Marxian language 82

Marxist-Leninist state 125

masculine agency, in Requiem para 0

Navegador Solitário 154, 158

masculine imperial subject-position 166

masculinity 221,288

Catarina relating to 164

dark continent and decentering of 273-78

enjoyment, imperial superego, and 160-67

heteronormative $161,163,166,169$

homosexual 164 imperial 218

imperial field of meaning and 164

interpellation and $167-70$

inter-tensions of 163-64

phantasmatic nature of $158,164,165$

whiteness relating to 177

masculinity undone, gender categories

and 279-86

The Masters and the Slaves see Casa Grande e Senzala

Mata, Inocência 252

matrix of domination 245

McMahon, Christina 269

meanings 27,31

of cannibal metaphor 63, 84, 93

see also field, of meanings

Medea, in 'Visão' 239-40

memoir, of Figueiredo 176-80, 183-88, 191-92, 199, 206-07

Mensagem do Terceiro Mundo [Message from the Third World] (Sylvan) 26, 135-43

Mensagen [Message] (Pessoa) 132

Message from the Third World see Mensagem do Terceiro Mundo

meta-identity 27, 134-35, 137-38,

141-42, 144

see also multicultural ethics, decolonial meta-identity and

metropolitan centrality 16

metropolitan imperial nostalgia 16

metropolitan whiteness 247

la mezcla (Anzaldúa) 251

Mignolo, Walter D. 29, 39, 40, 87, 231, 258

on colonity of power 9-10, 72

on decoloniality $8,12-13,135,234-35$

on geopolitics of knowledge and knowing 80-81

'Minimal Selves' (Hall) 138

Modern European languages 87

Modernismo movement members 97-98

modernisms 74-75

Brazilian 88, 104

European 88

to multiracial fascism $95^{-104}$

modernities $9,14,51,53,77-78,80$

industrial 81

Western 81,188 
modernization

decolonial non-imperial 80

in Pau Brasil 62, 62n2

monoculturalism 15

monologicism 15

Monteiro, Alberto Sacramento 149-58, $162,163,171$

Morrison, Toni 218

mourning 186-87, 188

'O Movimento Modernista' (Andrade, Mário de) 88

Movimento Nacional Feminino [National Women's Movement] 197

multicultural ethics, decolonial meta-identity and 106 conclusion to $143-44$ decolonizing pluri-racism nation 116-28

identity unfixed 128-35

imperial inscriptions of colony and bodies 107-16, 127, 164, 183, 287

postnation against Empire 135-43

multiculturalism 95

multiracial, Macunaíma as 70-71, 73

multiracial fascism, modernisms to 95-104

multiracial vision, of Brazilianness 95-96, 102-04

multitude, Jesus and 269-70, 276

o Mundo que o Português Criou ['The World the Portuguese Created'] (Freyre) 103

Name-of-the-Father 178, 192

narratives 18

decolonial, device, for colonial experience 208-10, 221-36 decolonial delinking and 232-35 of O Esplendor de Portugal 209-14 imperial 50, 67, 182-85

Lusotropicalism 117, 119, 121, 171, $175^{-76}, 181,183,184$

narrativizations $18,51,135$

historical 49, 68

imperial 50, 67

Western 50, 72, 79

national geographies, in Pau Brasil 61 national identity reformulation, with

Antropofagia 43-47, 51, 62

nationalism 9, 74-75, 76, 136-37, 253

national subjectivity 136

National Women's Movement see Movimento Nacional Feminino nation-sign, of Brazil 43-46, 62n1, 87, 92, 98, 101, 104-05

As Naus [The Return of the Caravels] (Antunes) 209

'Navio' ['Vessel'] (Sylvan) 129-30, 133-34

negritude 244

Negro 242

neocolonization 136

The Newest Testament see O Novíssimo Testamento

New World see Novo Mundo

N'Ganga, João Paulo 18-19

Niketche [Niketche] (Dias Martins) 260

A nona do Pinto Brás (Novela Timorense)

[Pinto Bras's Nona (A Timorese

Novel)] (Ferreira) 113

nonas, in East Timor 112-13, 155

No País do Tchiloli ['In the Country of Tchiloli'] (Beja) 31, 251-52, 253, 255, 258, 263

'Notes for a Chorographic Dictionary of Timor' see Apontamentos para um diccionário chorographico de Timor

o Novissimo Testamento [The Newest Testament] (Sousa, Mário Lúcio) 15-16, 31-32, 264-67, 288

plot of $265-73,285$

Novo Mundo [New World] (Figueiredo) 174

Occidentalism 10

cuvre 47 of Andrade, Oswald de 59

of Antunes 30, 209, 231

of Beja 31, 237, 245, 260

of Cardoso, Luis 27, 147, 148, 288

of Sousa 265

of Sylvan 106, 128, 136, 137

Olhos de Coruja Olhos de Gato Bravo ['Owl's Eyes Wild Cat's Eyes'] (Cardoso, Luis) 148

Orientalism 10, 40 
Orientalism (Said) 12, 40

The Origin of German Tragic Drama

(Benjamin) 48

Ortiz, Fernando 76-77

other

Lacanian theory of $30,54,84,235$, 246

phantasmatic 41, 123, 154, 220

Other $38,39,40-41,92,133$

big 84, 159-60, 164, 166, 235, 254, 272

desire of $84,93,160,161-62,165-66$, 167

otherness 32, 37, 39, 133, 142, 249, 274

colonial discourse on 10, 14, 79, 90,

97, 102, 139, 173, 189

consumption with $16,25,40-41,45$

fantasies of 75, 91, 122, 160, 166, 169,

171,242

messianic figure relating to 268

primitive 42

racial/ethnic $6,46,80,91,100,102$, 240

'Owl's Eyes Wild Cat's Eyes' see Olhos de Coruja Olhos de Gato Bravo

particularities, of Portuguese

colonialism 17, 20-21

'Passagem do Testemungo' (Sylvan) $142-43$

paternal function/enforcer, of father 181-82

paternalism, with colonial white womanhood 196

paternal specter, omniscience of 191-96

patriarchies 280

with colonialism 5, 85-86, 201

in Empire 181

in 'Manifesto Antropófago' 78

in Pau Brasil 57, 64

in Requiem para o Navegador Solitário

154-58, 161, 162, 171

Pau Brasil ['Brazilwood'] (Andrade,

Oswald de) 25, 35, 47, 48, 50

archetypal foundational in $51,54,64$, 66, 67

consuming Empire from periphery

54-65 decolonial potential of 63

economy in 56, 57-58, 61

genealogy in 63

national geographies in 61

patriarchy in 57,64

plagiarism associated with $55-56$

racial modernization in 62

as rewrite of Brazilian Western

historicization 55

signifying chain associated with 48 , $55,64-65,68$

slave labor in 56-57, 58-61

urban modernization in $62,62 \mathrm{n} 2$

violence in 58-62

Paulicéia Desvairada [Hallucinated City]

(Andrade, Mário de) 86

Pedrinha, Ponte 145, 146

Pereira, Geraldo Pinto, in Requiem para o

Navegador Solitário 156-63, 165

performativity 284-85

Pessoa, Fernando 132

phantasmatic centrality 126, 127, 134

phantasmatic cultural commonality 16

phantasmatic nature, of masculinity 158 , 164,165

phantasmatic other $41,123,154,220$

philosophical foundations, of Empire 15

Pinto Bras's Nona (A Timorese Novel) see

A nona do Pinto Brás (Novela Timorense) plagiarism

of Andrade, Mário de 15, 52-54

of Andrade, Oswald de 55-56

Playing in the Dark (Morrison) 218

'Pluri-Racial Community' see

Communidade Pluri-Racial

'Poemas da Colonização' (Andrade,

Oswald de) 46

political autonomy, Sylvan on 125

political reconstruction, of Lusophone

African nations 173

Portugal

early modern explorers of 209

expansion of 1-2

imperial subalternity of 16

language of $16,18,22-23,54,87,128$

literature of 21-24

orientalist fiction of 111

postcolonial experience of 17 
retracing colonial map of 16 women of 199 see also 0 Esplendor de Portugal

Portugal, contemporary imperial narrative of with disenfranchisement 183, 185 grand narrative $183-84$ ground narrative 184 with sports $182-83$

Portugal, East Timor and colonialism 107-15, 287 decolonization 145

Portuguese colonialism 121, 127, 171, 199, 208

atrocities of 191

of Brazil 1, 4

in East Timor 107-15, 287

end of $173-77$

marginalization with 21

particularities of $17,20-21$

three centuries of 42

Portuguese imperialism 1, 23

collaboration with $3,4,4 \mathrm{n} 2$

endeavor of 4

framework for 2-3, 5

history of 3

humanity impacted by 2

impact of 3

industrialism impacted by 2

power and privilege of $4,36,82,176$

power matrix impacted by $2-3,20$

resistance to 2

slave-based capitalism impacted by 2, 4

postcolonial experience, of Portugal 17 postcolonial inscription 147

postcolonialism, Lusophone 18, 20-21, 176

postcoloniality 37,137

collective level of 66

cultural critique of 47

decolonial politics, Empire, and 6-16

plight of $50-51$

postcolonial literatures $23-24,27,33$,

40,248

postcolonial meaning 31

postcolonial metropolitan nation 232 ,

234 postcolonial nationhood $6,68,136$

postcolonial renegotiation 255

postcolonial studies 5, 6-8, 9, 11-12, 21

Postcolonial Studies 18

postcolonial theory 11,13

post-imperial identity $111,111 \mathrm{n} 2$

postnation, against Empire 135-43

postnationalism, decoloniality of 21-24

power 7

of coloniality 3-4, 8-9, 10, 72, 213, 221

dominant narratives of 18

economic, of Brazil 4

field of 161

gendered 280

imperial 1, 40, 225

privilege and $4,36,82,176$

to subaltern subjects 36

power matrix, Portuguese imperialism impact on $2-3,20$

preadolescent episodes, of Figueiredo 199-200, 204-05

Preto no branc: (N'Ganga) 18-19

Os Pretos de Pousaflores ['The Blacks of Pousaflores'] (Gomes) 174

primitive

consumption of $37-42$

historical 38

otherness 42

primitivism $35,37,40-42,43$

with Antropofagia 38-39

Brazil relating to 39

European 39

Príncipe, 21, 30, 237, 241, 251, 252, 258-59

privilege, power and 4,36, 82, 176

privileges, of father 178

Quijano, Aníbal 8-9, 9n3

race

colonial discourse of 223,247

gender, class, sexuality, disability, and 264-65, 288

imperial categories of 71

Kantian 99

'Race, the Floating Signifier' (Hall) 248

racial boundary 198 
racial class system 192

racial democracy $18,72,100,102,102 \mathrm{n} 1$, 103-04

racial difference, signification of 121 , 163,222

racial identity 174

racialized subjectivity 242

racial modernization, in Pau Brasil 62

racial otherness

ethnic and 6, 46, 80, 91, 100, 102, 240

fantasies of sexual and 178-79, 220

racial segregation 198

racial signifiers 213,249

racism 16, 18, 19, 20, 103

epistemology and 40

European 122

Racismo, opressão dos povos [Racism and the

Oppression of Peoples] (Sousa, Vinício de) 19

O Racismo da Europa e a Paz no Mundo

[The Racism of Europe and World Peace]

(Sylvan) 26-27, 122, 123, 127, 129, 133

Rancière, Jacques 233-34

rape $28,60,149,154,155,171,183$

rationalism 89

Real 160

realm, of concepts 89-94

Reason

Cartesian dictum of 135

Empire and 89-91

Rebelo, Tiago 174

reincarnation, of Jesus 31-32, 266-68, 273, 275, 280, 286

Renan, Ernest 266-67

repetition, consumption, allegory 65-68

reproduction, of Empire 132, 160, 218, 223, 243, 245-46, 287

Requiem para o Navegador Solitário

[Requiem for the Solitary Sailor]

(Cardoso, Luis) 27-28, 145

Catarina as narrator of $149-56$, 167-72

East Timor as location of 149-56

Iberian Peninsula in 151, 151n1

jouissance in 156-60

Law associated with 161-62, 163, $164-67,168,171-72$

Malisera in $151,152,153,156$ masculine agency in 154,158

Monteiro in 149-58, 162, 163, 171

patriarchy in 154-58,161, 162, 171

Pereira in $156-63,165$

transcontinentalidade in 150

resignification $27,46-47,78,95$

retornados $173-74,175,182$

Os Retornados ['The Returnees']

(Magalhães) 174

O Retorno ['The Return'] (Cardoso, Dulce Maria) 174

'The Returnees' see Os Retornados

The Return of the Caravels see As Naus

Revista de Antropofagia 44, 46

revolutionary internationalism 5

Ribeiro, Grácio 111

Ricardo, Cassiano 71

'Rota' ['Route'] (Sylvan) 130-31, 133-34

Rothwell, Phillip 181

Rui, in O Esplendor de Portugal 210, 211, 214

Said, Edward 12, 24, 40, 136-37

Salgado, Plínio 26, 71, 97-98, 101

São Paulo 33, 61, 70

elites of $73,77,78,82-83,86$

industrial city of $62,82-83,85$

journey to 26,79

'São Tomé 21, 30-31, 237, 241, 251-52, $255,258-59$

scene of writing 269

anthropophagic 87, 89, 91, 92

centerless 135

decolonial 79, 85, 91, 94, 170-71

Schwartz, Roberto 35-37

Semedo, César 168-69

'Sermon on the Mount' 273, 275, 277

7 Poemas de Timor ['7 Poems of Timor']

(Sylvan) 129, 135

sex, interracial 181, 182, 199, 220-21,

244,247

sexual and racial otherness, fantasies of

$178-79,220$

sexual identities 279

sexuality

female 199, 201, 278-80

of Figueiredo 177, 178-80, 182, 196-203, 204-05 
race, gender, class, disability, and 264-65, 288

sexual liaisons, of father 196-97

sexual taxonomies 196

sexual violence 181,182

'Signature, Event, Context' (Derrida) 284

signification 289

Jesus, as black elderly woman, and 274,285

of racial difference $121,163,222$

resignification $27,46-47,78,95$

of time, space, bodies 237, 287

significational gaze, of Macunaíma

$70-71,84$

signifying chain

of Empire 5, 34, 44-45, 47, 138, 143 , 188, 190, 212-13, 229, 231-32, 257

Pau Brasil relating to $48,55,64-65,68$

sign-systems 12, 13, 24, 257-61

of Beja 262, 263

Silva, Daniel F. 12

sins, of father 206-07

slave-based capitalism 2, 4

slave labor, in Pau Brasil 56-57, 58-61

slavery 4, 57, 83, 103-04, 183, 263

slave trade, African 3, 4, 20, 41, 85

Soares, Anthony 128

The Souls of Black Folk (Du Bois) 258

Sousa, Mário Lúcio 15-16

background of 264-65

cuvre of 265

Sousa, Vinício de 19

South of Nowhere see Os Cus de Judas

'Sozinha no Palco (Lusófono)?'

(McMahon) 269

spaces of production, subalternity,

privilege of urban terrain, and 83

Spanos, William 6

spatial movement, in Macunaíma 71

specter

of father 205-07

paternal 191-96

persistence of 205-07

Specters of Marx (Derrida) 185

spectral, specular and

Carlos relating to $221-25$

Isilda relating to $221-27$ spectral composition, of O Esplendor de

Portugal 211-21

spectrality, as decolonial narrative

device for colonial experience 208-10

colonial spaces relating to $227-31$,

232

conclusion to $235-36$

decrepit narratives and decolonial

delinking 232-35

spectral and specular 221-27

spectrality, imperial public sphere and

185-88, 185n3, 189, 195, 201-03

specular see spectral, specular and

specular image 249

Spivak, Gayatri 271-72

The Splendor of Portugal see O Esplendor de Portugal

Sterne, Laurence 214

subaltern $26,63,77$

global movement of 19

History and 73

subjectivities 49

subalternity $82,83,85,111,280$

common experiences of $138,143-44$

imperial, of Portugal 16

with imperialism 3, 4, 5, 20, 132

untranslatable 145

Subaltern Studies Collective 9, 12

subaltern subjects, power to 36

subjectivation $12,13-14,84-85,162$,

195, 222

gendered 285

intersectionality of $245-50$

subjectivities 137

decolonial 67

national 136

racialized 242

subaltern 49

Subjectivity and the Reproduction of Imperial

Power (Silva) 12

subject-positions 166, 229, 263, 272

superego 160-67

Super-Prosperos 21

Sylvan, Fernando 3, 15, 18, 24

ambiguities of 116-28

background of 106

'body-institution' of 118

on 'civilização-padrão' 123-24 
on colonialism $125,127,136$

on communism $125-26$

on decolonizing pluri-racial nation

116-28

on 'Discoveries' 121-22, 131

on Estado Novo 114, 126

on European racism 122

on European supremacy 123-24

identity unfixed relating to $128-35$

as interlocutor 117

interpellation of 118

cuvre of 106, 128, 136, 137

policies proposed by $117-20$

on political autonomy 125

sea in work of 131-32

writings of 26-27, 116-28, 125n3,

129-31, 133-34, 135-43

symbolic function, of father 178

Tamagnini, Isabel 113

Tapanhumas 70

Tapuia 98-99

tavern, Jesus in $281-83,284$

taxonomies 281

Empire relating to $4-5,45,85,237$, 272

sexual 196

tchiloli 252-53

'Ten Thesis on Politics' (Rancière) 233

'Terra' ('Earth') (Beja) 259

A terra, a gente e os costumes de Timor

(Braga) 112

Tetun-Prasa 145-46

Third Age, of Jesus 269-70

Third World 137, 138-39, 142

'Third World Literature in the Era of Multinational Capitalism' (Jameson) 33

Timor 1930: Pais de Sonho e Encantamento ['Timor 1930: Country of Dreams and Enchantment'] (Braga) 109

Timorese Social Democratic Association see Associação Social Democrática Timorense

Tlostanova, Madina V. 13, 231

Torok, Maria 29, 180, 188

totalitarian modes, of existence 289

Totem and Taboo (Freud) 63
Toussaint-Samson, Adèle 41, 42

Tragédia do Marquês de Mântua e do Imperador Carlos Magno ['The Tragedy of the Marquis of Mântua and the Emperor Charlemagne'] (Dias) 252

transcontinentalidade 150

transculturación 76

transculturation renegotiation culture democratization with 78-79

deculturation 76

nationalism relating to $75-76$

repetition with 78

version of $76-77$

transgendering, of Jesus 264-67, 280-81, 288

transnational consciousness 24

Tropical Belle Époque 34, 42, 72

Tupi 14, 45, 47, 52, 71, 98-101

A Última Morte do Coronel Santiago ['The

Final Death of Colonel Santiago']

(Cardoso, Luis) 148

O Último Ano em Luanda ['The Last Year in Luanda'] (Rebelo) 174

Undoing Gender (Butler) 283

United States, East Timor relating to 116

urban industrial imagery 81

Valete 19-20

Vargas, Getúlio (president) 34, 95

propaganda of 96

samba established by 96

Vasconcelos, José 88, 100-01

Verde-Amarelismo movement 26, 71, 97, 98-101, 102

'Vessel' see 'Navio'

Victory (Conrad) 109-10, 115

violence

colonial 182, 186, 191, 205

in Pau Brasil 58-62

sexual 181, 182

'Visão' ['Vision'] (Beja) 237-38, 251, 253

blackness in $240-50$

historicization of events in 242

interpellation in 240

intersectionality in $246,249-50$

Medea in 239-40

'Vision' see 'Visão' 
'Wanderings of a Timorese' see Andanças de um Timorense

Weltanschauung 122

West

expansion of 8

historicism of 67-68

history of 68

imperialism of $1,3,6,7,10,44,50$

modernity of 81,188

narrativization of 50, 72, 79

whiteness 72, 91, 94, 101, 102, 220, 249

colonial 199

compromised 174

discourse of 212,213

fantasies of 189,246

of heteronormative masculinity 195

historicization and 73

laws of 181

masculinity relating to 177

metropolitan 247

public image of 210

white superiority 85,244

white wife 199

white women 202, 205

black women and 178-80, 183, 221, 246-47

cisgendered 178, 191
Figueiredo as 178

The Wolf Man's Magic Word (Abraham and Torok) 188

women

black 178-80, 183, 221, 240, 246-47

men and, of color 181

of Portugal 199

sexuality of $273,279-80$

see also colonial white womanhood; Jesus, as black elderly woman;

white women

'The World the Portuguese Created' see 0

Mundo que o Português Criou

Wretched of the Earth (Fanon) 141

Writing Diaspora (Chow) 248

writings

of Cardoso, Luis 145, 148, 149

of Derrida 11, 27, 29, 78, 134, 185, 188, 203, 284

resistance, inscription, and, of jouissance 156-60

see also scene of writing

Young, Robert J. C. $247-48$

Žižek, Slavoj 158-59, 160, 161, 164, 166

Zurara, Gomes Eanes de 2 






